$$
\text { mis }
$$

\section{GEOLOGY OF THE STROUDSBURG QUADRANGLE AND ADJACENT AREAS, PENNSYLVANIA--NEW JERSEY}

By

Jack B. Epstein

U.S. Geological Survey 
GEOLOGY OF THE STROUDSBURG QUADRANGLE AND ADJACENT AREAS, PENNSYLVANIA--NEW JE'RSEY

By

Jack Burton Epstein

ABSTRACT

The Stroudsburg area is within the Valley and Ridge and Great Valley physiographic provinces, Northampton and Monroe Counties, Penrsylvania, and Warren County, New Jersey. The northeast-trending subparallel valleys and ridges resulted from erosion of folded heteroüeneous sedimentary rocks. These are Middle Ordovician to Middle Devonian in age and are more than 17,000 feet thick.

Deposition of a thick flysch sequence (Martinsburg Formation of Ordovician age) accompanied onset of Taconic orogenesis. It was followed by deposition of a thick molasse sequence of Silurian and Early Devonian age (continental and marinal-marine clastics--Shawangunk Formation and Bloomsburg Red Beds--overlain by predominantly marginal-marine and subtidal limestone, dolomite, shale, and sandstone--Poxono Island Formation through Oriskany Group) . Basin deepening and gradual shallowing occurred during Esopus through Mahantango deposition, heralding the Acadian clastic wedge exposed north of the Stroudsburg area. Interpretation of sedimentary structures and regional stratigraphic relations suggest that the Silurian and Devonian rocks were deposited in the following environments: Alluviated coastal plain (meandering and braided streams), tidal flats 
(supratidal and intertidal), barrier zone, and neritic zone (upper and lower).

The rock stratigraphic units have been grouped into four lithotectonic units, each having a different style of deformation. Folds produced in these rocks are disharmonic, and it is believed that each rock sequence is set off from units above and below by décollements, or zones of detachment. Movement was northwest into the Appalachian basin, primarily by gravitational sliding. The contact between the Shawangunk Formation of Silurian age and Martinsburg Formation of Ordovician age, is one zone of detachment as well as an angular unconformity.

Deformational effects of the Middle to Late Ordovician Taconic orogeny are elusive, but it appears that the folds and most minor structures, including the prominent regional cleavage, were produced during the late Paleozoic Appalachian orogeny and are superimposed upon larger Taconic folds and faults.

Field relations and microscopic study suggest that the regional cleavage in the Stroudsburg area is due to laminar flow of pelitic material along cleavage folia accompanied by mechanical reorientation of platy and elongate minerals and neocrystallization of mica, quartz, chlorite, and probably albite. Numerous lines of evidence point to the conclusion that cleavage developed after the rock was indurated and formed at, and just below, conditions of low-grade metamorphism. Intensity of cleavage development increases to the southeast across the area. Second-generation slip 
cleavage, also believed to be Appalachian in age, formed by mechanical reorientation of minerals as well as by limited new mineral growth.

The topography had a profound effect on the direction of movement of the Wisconsin glacier, as well as the manner of its retreat and the deposits that were formed. Till and stratified drift of Wisconsin age and till of Illinoian(?) age are common in the area. Wisconsin deglaciation occurred by northeastward retreat and by stagnation. A conspicuous terminal moraine marks the limit of Wisconsin ice movement. Lake Sciota was dammed between the retreating ice, the moraine, and the surrounding ridges north of Godfrey Ridge. Several deltas mark ice stand positions during the retreat of the ice. Lake-bottom and kame deposits are locally common in Cherry Valley. South of Kittatinny Mountain, on the other hand, melt water was freely discharged to the south.

The wind and water gaps in the Stroudsburg area (including Delaware Water Gap and Wind Gap) are structurally controlled; specifically they are located where folds die out in short distances, where folding is locally more intense, or where resistant rocks dip steeply and have a narrow width of outcrop. This conclusion is contrary to the concept of regional superposition. 


\section{ACKMOHTEDGNENTS}

I have benefited from exchange of lieas and discussions with many geologists in the field and from their critical comments on several manuscripts preceding this dissertation. I extend wy gratitude to C. S. Denny, A. A. Drake, Jr., and J. H. Hartshorm, U. S. Geological Survey, G. G. Connally, Lafayette College, and the late V. E. Gwinn. Thanks also go to the many geologists, too numerous to mention, who have visited me in the field and participated in field trips. Sincere appreciation is extended to Dr. George E. Moore, Jr., adviser of this dissertation. Special acknowledgment goes to my wife and coworker, Anlta, who ably acted as field assistart, measured many stratigraphic sections with me, and was a source of constant inspiration. Acknowledgment is made of the support granted by the Bownocker Fund of the Departinent of Geology, The Oh10 State Uaiversity, which assisted we in the completion of my graduate studies. 
TABIE OF. CONIENTS

Page

Acknowledgments . . . . . . . . . . . . .

Tables ....................... $x i$

Illustrations . . . . . . . . . . . . . . . . xil

Introduction ...................... I I

Bedrock Stratigraphy ................ 6

Ordovician .................. 6

Martinsburg Formation ............ 6

Bushk1ll Member . . . . . . . . . . 10

Ramseyburg Member .............. 10

Pen Argyl Member ... . . . . . . . . . 11

Age of the Martinsburg Formation . . . . . . . 13

Petrography .................. 14

Silurian .................... . . 21

Shawangunk Formation ............... 21

Mins1 Member .. . . . . . . . . . . 22

Clinton Member ................ 29

Tammany Member . . . . . . . . . . . 32

Age of the Shawangunk Formation . . . . . . . . 46

$i i-v i$ 
TABIE OF CONTENTS (Continued)

Page

Bloomsburg Red Beds..............

Poxono Island Formation . . . . . . . . . .

Bossardville Llmestone . . . . . . . . . .

Decker Formation ...................... 63

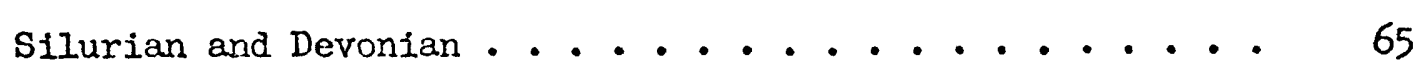

Rondout Formation ................ 67

Duttonville Member ............ 67

Whiteport Dolomite Member ........... 68

Mashtpacong Member ........... . . 72

Devonian ........................ 73

Helderberg Group ............... 73

Coeymans Formation ............... 73

Depue Limestone Member ............ . 75

Peters Valley Member ............. 77

Shawnee Island Member . . . . . . . . . 77

Storaville Member ............. 80

New Scotland Formation .............. 83

Flatbrookville Member ............ 83

Maskenozha Member............... 84

Minisink Limestone ..................... 84 
TABIE OF CONIENTS (Continued)

Page

Port Ewen Shale ................. 85

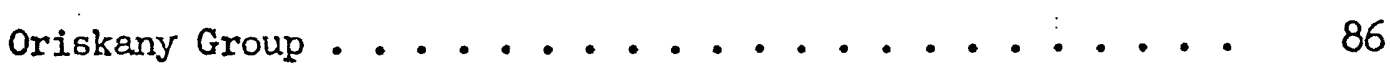

Shriver Chert ................ 90

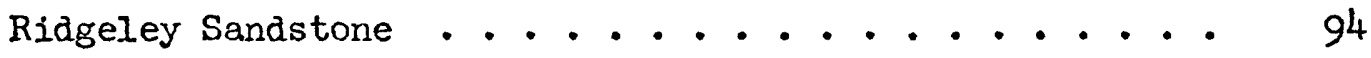

Post-Oriskany and Pre-Hamilton Rocks ......... 95

Esopus Formation . . . . . . . . . 96

Schoharie Formation . . . . . . . . . 98

Buttermilk Falls Limestone . . . . . . . . 103

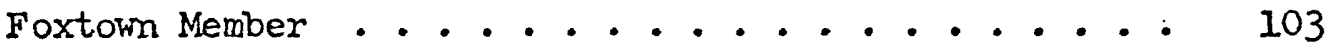

McMichael Member ............ 108

Stroudsburg Member ........... 110

Hamllton Group . . . . . . . . . . 112

Marcellus Shale.................... 113

Stony Hollow and Union Springs Members, undifferentiated 113

Brodhead Creek Member . . . . . . . . 118

Mahantango Formation ............ 120

Quaternary .................... 121

Environments of Deposition ............. 123

Surficlal Geology ................. 147

Illinolan(?) Glaclal Deposits ........... 147 
TABLE OF CONTENTS (Continued)

Page

Wisconsin Glacial Deposits .......... 148

Phases of Deglaciation ............ 151

Late and Postglacial Deposits .......... 153

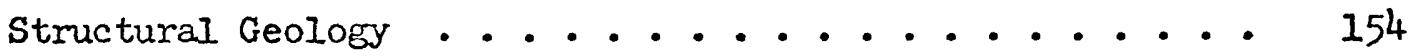

Décollements ................. 157

Lithotectonic Unit 1 . . . . . . . . 160

Lithotectonic Unit 2 . . . . . . . . 190

Lithotectonic Unit $3 \ldots \ldots 198$

Lithotectonic Unit 4 . . . . . . . . 202

Small-scale structures ................ 204

Lineations . . . . . . . . . . 204

Joints ...................... 208

Bedding ............................... 210

Cleavage ..................... 212

Cleavage in Lithotectonic Unit I . . . . . . 222

Metaworphism in the Martinsburg Formation ...... 232

Cleavage in Lithotectonic Unit 2........ 243

Cleavage in Lithotectonic Unit $3 \ldots . . . . . . .247$

Cleavage in Lithotectonic Unit $4 \ldots \ldots 257$

Cleavage Summary . . . . . . . . 259 
TABLE OF CONTEMS (Continued)

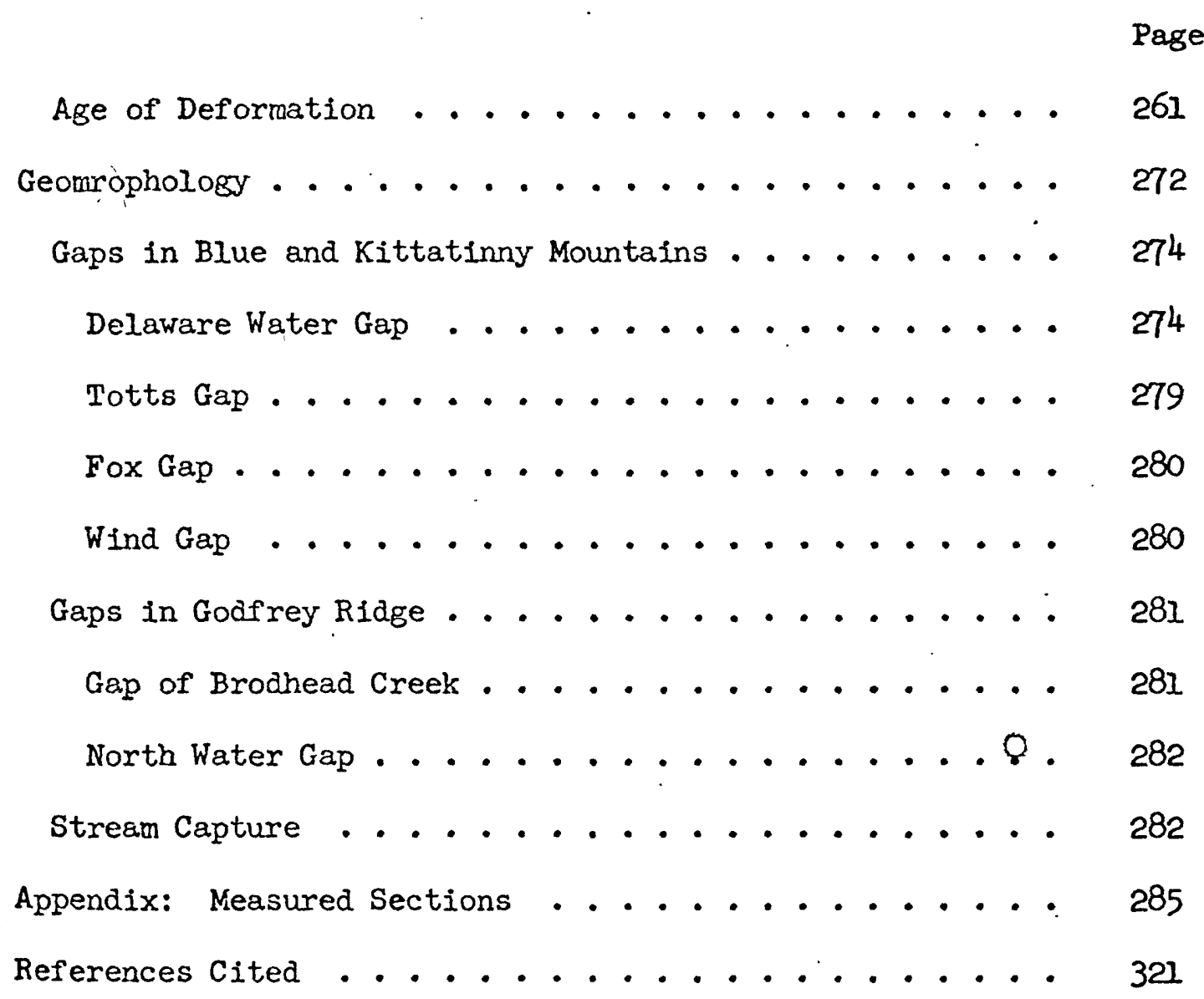




\section{LIST OF TABIES}

$\begin{array}{ll}\text { Table Page } & \text { Pa }\end{array}$

I. Chemical analyses, Martinsburg Formation . . . 17

2. Chemical analyses, Shawangunk Formation ..... 28

3. Iithotectonic units in the Stroudsburg area. . . 156 


\section{LIST OF IIUUSTRATIONS}

Figure

1. Index map of parts of eastern Pennsylvania and northwestern New Jersey . . . . . . . .

2. Panoramic view from Cherry Ridge showing geologic features in the Stroudsburg quadrangle . . .

3. Slate block, Martinsburg Formation ....... 12

4. Photomicrograph of slate, Pen Argyl Member, Martinsburg Formation . . . . . . . . .

5. Photomicrograph of Iithic (calcitic) graywacke, Pen Argyl Member, Martinsburg Fordation . . . . 18

6. Photomicrograph of Iithic graywacke, Pen Argyl Member, Martinsburg Formation . . . . . .

7. Photomicrograph of feldspathic graywacke, Ramseyburg Member, Martinsburg Formation ........ 20

8. Stratigraphic section of Shawangunk Formation, .

Bloomsburg Red Beds, and Poxono Island

Formation, easternmost Pennsylvania . . . .

9. Quartzite and conglomerate, Minsi Member, Shawangunk Formation at type section, Delaware Water Gap .

10. Mud-cracked siltstone, Minsi Member, Shawangunk Formation, Delaware Water Gap . . . . . .

11. Photomicrograph of feldspathic sandstone, Minsi Member, Shawangunk Formation . . . . . .

12. Photomicrograph of siltstone, Minsi Member, Shawangunk Formation . . . . . . . . .

13. Clinton Member of the Shawangunk Formation at reference section, Delaware Water Gap . . . . 


\section{LIST OF ILUUSTRATIONS (Continued)}

Figure

14. Laminated sandstone, Clinton Member, Shawangunk

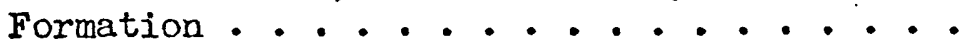

15. Ripples in Clinton Member, Shawangunk Fortnation . .

16. Flaser-bedded sandstone and burrowed siltstone, Clinton Member, Shawangunk Formation . . . .

17. Convolutions in sandstone and siltstone, Clinton Member, Shawangunk Formation ........

18. Photomicrograph of phosphatic shale in protoquartzite, Clinton Member, Shawangunk Formation

19. Photomicrograph of fine-grained quartzite, Clinton Member, Shawargunk Formation . . . . . .

20. Feeding burrows in siltstone, Clinton Member, Shawangunk Formation ..........

21. Type section of Tamany Member, Shawangunk Formation, Delaware Water Gap ... . . . 40

22. Photomicrograph of conglomeratic protoquartzite, Tammany Member, Shawangunk Formation ..... 42

23. Dolomite and dolomitic shale or shaly dolomite, Tammany Member, Shawangunk Formation .... 43

24. Photomicrograph of dolomite replacing shale, Tammany Member, Shawangunk Formation ........ 45

25. Upward-fining cycles in Bloomsburg Red Beds . . . 53

26. Photomicrograph of siltstone to feldspathic graywacke, Bloomsburg Red Beds . . . . . . 56

27. Iaminated Iimestone and calcareous shale in mudcrack, Bossardville Limestone ........ 60

28. Graded beds in Bossardville Ifmestone ....... 61 


\section{LIST OF IILUSTRATIONS (Continued)}

Figure

Page

29. Photomicrograph of finely bedded ostracode-biomicruaite and micrite, Bossardville Limestone

30. Mudcracks, Bossardville Limestone ........

31. Photomicrograph of conglomeratic sandy calcisiltite, Decker Formation ..........

32. Photomicrograph of biomicmaite in biostrome, Duttonville Member, Rondout Formation ....

33. Mudcracks in Whiteport Dolomite Member, Rondout Formation ............... 70

34. Mudcrack in laminated ferroan dolomite, Whiteport Dolomite Member of the Rondout Formation ...

35. Helderberg and Oriskany Group in overturned syncline along U.S. Interstate $80 . . . .$.

36. Negetive print of thin section of biosparmadite and calcareous siltstone, Depue limestone Member of Coeymans Formation ........

37. Photomicrograph of sandy biopelsparrudite in Shawnee Island Member of Coeymans Formation . .

38. Storurville Member of Coeymans Formation . . . .

39. Photomicrograph of calcareous orthoquartzite, Stormville Member of Coeymans Formation . . .

40. Photomicrograph of calcareous shaly siltstone, Port Ewen Shale ..............

41. Fossiliferous calcareous siltstone to quartzose calcisiltite, Port Ewen Shale . . . . . . .

42. Sandstone and fossiliferous chert, Shriver Chert of Oriskany Group .............. 


\section{LIST OF ILLUSTRATIONS (Continued)}

Figure

Page

43. Burrowed calcisiltite, Shriver Chert, Oriskany

Group .. . . . . . . . . . . 92

44. Photomicrograph of very coarse grained orthoquartzite, Shriver Chert, Oriskany Group . . . 93

45. Schoharie Formation near Buttermilk Falls . . . . 99

46. Taonurus in Schoharie Formation ......... 101

47. Photomicrograph of siltstone, Schoharie Formation - 102

48. Cherty Iimestone and crinoid columnal in Foxtown Member of Buttermilk Falls Limestone . . . . 104

49. Photomicrograph of cherty biomicrite, Foxtown Member of Buttermilk Falls Limestone . . . . . . 105

50. Limestone and argillite in McMichael Member of Buttermilk Falls Limestone . . . . . . 109

51. Unevenly bedded chert and limestone in Stroudsburg Member of Buttermilk Falis $L_{i}$ mestone at type section ................. 111

52. Stony Hollow Member of Marcellus Shale . . . . 116

53. Photomicrograph of calcareous siltstone in Stony Hollow Member of Marcellus Shale . . . . . 117

54. Photomicrograph os silty shale in Brodhead Creek Member of Marcellus Shale . . . . . . . 119

55. Heliophyllum in Centerfield biostrome of Mahantango Formation . . . . . . . . . . . 122

56. Block diagram showing sedimentary environments and major Iithofacies in northeasternmost Pennsylvania from Silurian through Middle Devonian . .

57. Histogram showing current trends from crossbedding in Shawangunk Formation at Delaware Water Gap . 


\section{IIST 'OF ILIUSTRATIONS (Continued)}

\section{Figure}

58. Taonurus, a burrow, Esopus Formation . . . . .

59. Wisconsin till along Erie-Lackawanna Railroad . . 149

60. Delta topset and foreset beds in gravel pit . . . 150

61. Diagrammatic sketch and section showing pre-Wisconsin drainage divide and position of Wisconsin glacier at time of deposition of delta in Lake Sciota during deglaciation phase 2.........

62. Geologic map and section of Bangor Fidelity and West Bangor slate quarries ........ 164

63. Geologic map and section of Northampton slate quarry 166

64. Geologic map of New Peerless and Strunk slate quarries 168

65. Nearly recumbent syncline in Strunk slate quarry - 169

66. Diagrammatic section showing structural position of New Peerless and Strunk slate quarries . . . 170

67. Minor cleavage arch and fault about 300 feet south of New Peerless slate quarry . . . . . . 172

68. Geologic map of the Shimer, Consolidated No. 3, and Consolidated No. 2 slate quarries . . . 175

69. Operations in the Capitol Slate Co. quarry . . . 177

70. Geologic and topographic map of the Capitol Slate Co. quarry .............. 178

71. Geologic map and section of the Columbia Bangor, New Bangor, and Bangor Excelsior slate quarries 181

72. Geologic map and section of the Snowdon slate quarry ..................

73. Slip cleavage in Snowdon slate quarry ...... . 186 


\section{IIST OF ILLUSTRATIONS ( Continued)}

Figure

Page

74. Geologic map and section of the Frye slate quarry - 188

75. Panoramic view of Delaware Water Gap showing axial traces of folds........... . . 192

76. Fold and underthrust in Clinton Member of Sharangunk Formation, Delaware Water Gap . . . . . . 193

77. Wedging and bedding-plane slip in Bloomsburg Red Beds 196

78. Cascade folds in Ridgeley Sandstone and Esopus Formation . . . . . . . . . . . 199

79. Variation in plunge of fold in Buttermilk Falls Limestone . . . . . . . . . . . 200

80. Divergent fanning of cleavage in Port Ewen Shale - 201

81. Cross sections showing nature of displacement along high-angle fault in Brodhead Creek . . 203

82. Small cross fold in Martinsburg Formation . . . 206

83. Equal-area projections of intersections of bedding and cleavage in Stroudsburg quadrangle . . . 207

84. Equal-area projections of poles to joints in the Stroudsburg quadrangle .. . . . . . . 209

85. Equal-area projections of poles to bedding in the Stroudsburg quadrangle . . . . . . . . 211

86. Equal-area projections of poles to cleavage in the Stroudsburg quadrangle ........... 214

87. Refracted cleavage in Pen Argyl Member of the Martinsburg Formation ............ .

88. Photomicrographs of porphyroblasts, pressure-shadow neomorphism, and cleavage cutting bedding-plane slickensides in the Martinsburg Formation . . . 
LIST OF ILLUSTRATIONS (Continued)

Figure

89. Photomicrograph of slip cleavage in Martinsburg

Formation . . . . . . . . . . . . .

90. Cross section through Delaware Water Gap showing

"arching" of cleavage in Martinsburg Formation

near contact with Shawangunk Formation . . .

91. Divergent fanning of cleavage in flattened fold in

Martinsburg Formation ..........

92. Mud dike intruding graywacke, Martinsburg Formation

93. Photomicrograph of slaty cleavage offsetting mud

dike

94. Photograph of thin section showing divergence of cleavage around lens of sandstone, clinton

Member of Shawangunk Formation .......

95. Photomicrograph of needle quartz in cleavage folia, Clinton Member, Shawangunk Formation . . . .

96. Photomicrograph of slip cleavage in Clinton Member of Shawangunk Formation ......... 246

97. Photomicrograph showing cleavage in siltstone to graywacke in Bloomsburg Red Beds ......

98. Slaty cleavage in Port Ewen Shale . . . . . 249

99. Photomicrograph showing crush quartz and pressure shadow growth of quartz, muscovite, and chlorite around pyrite grain parallel to cleavage . .

100. Photomicrograph of needre quartz and muscovite parallel to cleavage in the Shriver Chert of the Orlskany Group . . . . . . . . . . .

101. Negetive print of thin section showing intrusion of calcite and quartz along cleavage folla in the Bossardville Limestone . . . . . . . . . 


\section{LIST OF ILLUSTRATIONS (Continued)}

Figure

Page

102. Photomicrograph of calcareous sandstone showing growth of quartz and cleavage cutting brachiopod shell in Schoharie Formation . . . . .

103. Photomicrograph of stylolites cut by cleavage in silty Iimestone, Shriver Chert of Oriskany Group .................

104. Deformed mudcrack polygons and preferential development of cleavage in the $b$ direction in Whiteport Dolomite Member of the Rondout Formation ........... 255

105. Slip cleavage in Mashipacong Member of Rondout Formation ........... 258

106. Composite equal-area projections showing maxima of poles to bedding and cleavage, maxima of intersection of bedding and cleavage, and average strike of bedding in all lithotectonic units in the Stroudsburg quadrangle ...... 266

107. Physiographic diagram of the Stroudsburg area, Pennsylvania and New Jersey ........ . 275

108. Geologic map and projected longitudinal profile, showing relation of geologic structure to location of gaps in Blue and Kittatinny Mountains, Stroudsburg area ....... 276

109. Reconstructed flexure at Delaware Water Gap . . . 278

\section{Plate}

I. Geologic map of the Stroudsburg quadrangle and All plates part of the Portland quadranele, Pennsyl- in pocket vania--New Jersey

II. Cross sections of the Stroudsburg and Portland quadrangles 
LIST OF ILLUSTRATIONS (Continued)

Plate

III. Geologic map and sections of Godfrey Ridge,. AIl plates Stroudsourg and East Stroudsburg quadrangles, Pennsylvania.

IV. Surficial geologic map of the Stroudsoure quairangle, Pennsylvania--New Jersey

V. Topographic map of the Stroudsburg quadrangle showing location of slate quarries described in text

VI. Topographic map of the Portland quadrangle showing location of slate quarries described in text 


\section{INTRODUCT ION}

The Stroudsburg quadrangle and surrounding areas discussed in this report lie within the Valley and Ridge and Great Valley physicGraphic provinces in Northampton and Monroe Counties, Pennsylvania, and Warren County, New Jersey (fig. 1). The northeast-trending subparallel valleys and ridges are the result of erosion of folded heterogeneous sedimentary rocks (fig. 2) aggregating more than 17,000 feet in thickness and ranging in age from Middle Ordovician to Middle Devonian. The rock stratigraphic units have been grouped into four successive lithotectonic units, each of which has a different style of deformation. Folds produced in these rocks are disharmonic, and it is believed that each rock sequence is set off from sequences above and below by a décollement, or zone of detachment. Hovement was northwest into the Appalachian basin, prinarily by gravitational sliding, aided by directed tectonic forces. The contact between the Shawangink Formation of Silurian age and Martinsburg Formation of Ordovician age, believed by most workers to be an angular unconformity, may also be one zone of detachment. Deformational effects of the Hiddle to Late Ordovician Taconic orogeny in pre-silurian rocks are elusive, and it appears that the folds and most minor structures, including the prominent regional cleavage, were produced during the late Paleozoic Appalachian orogeny and are superimposed upon larger Taconic folds and faults. Sedimentalogically, uplift during the Taconic orogeny resulted in the 


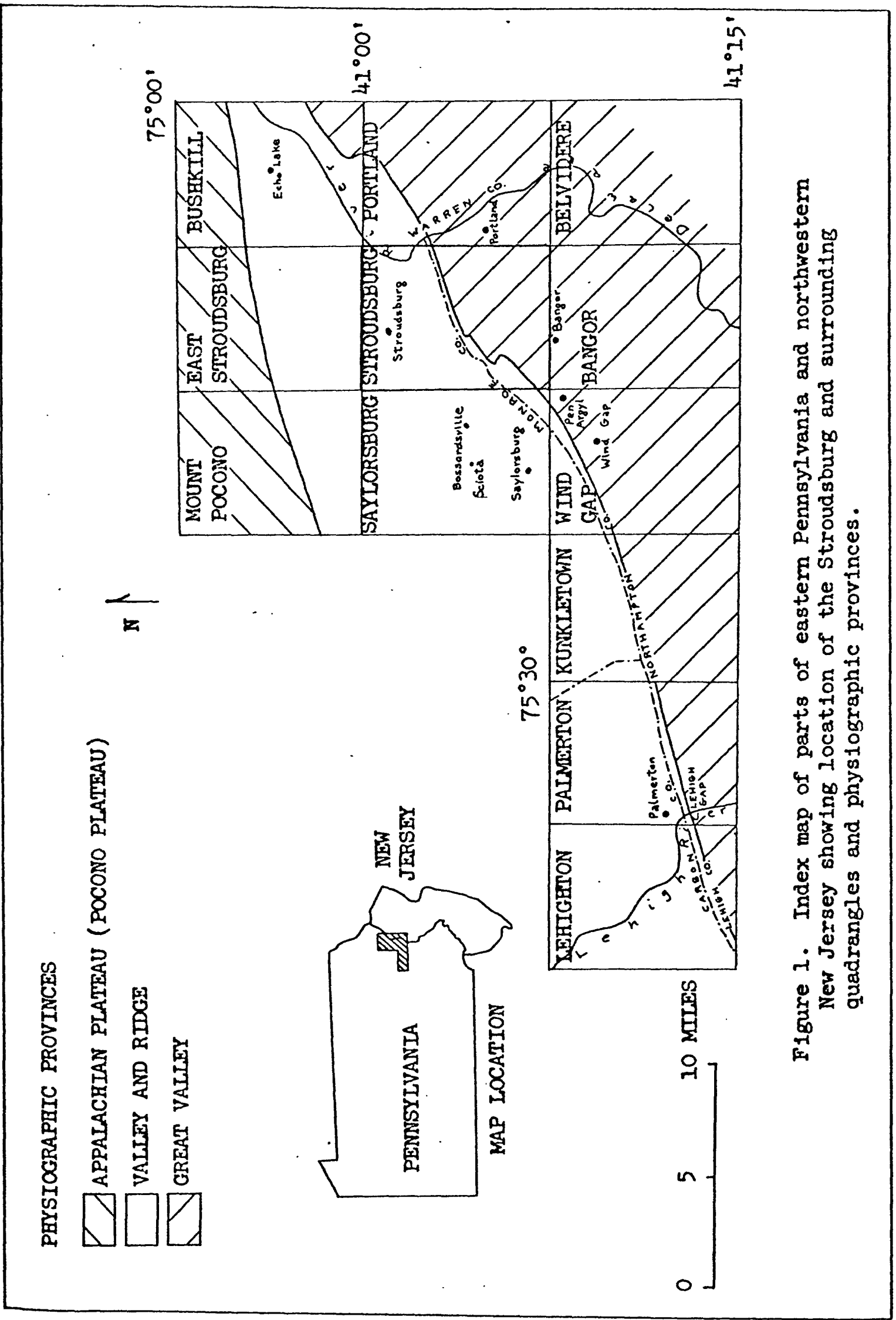




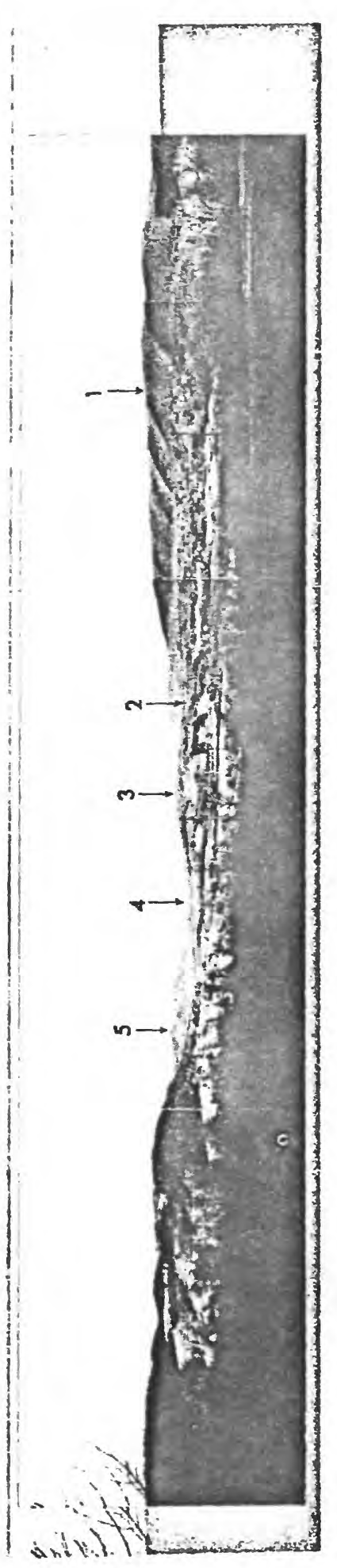

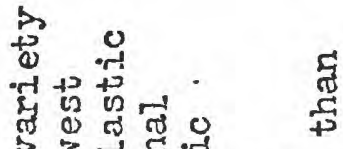

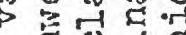

委

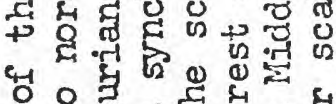

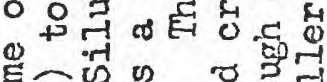

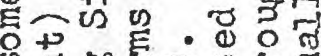

娄

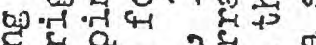

4 \& 000 दै

हैं

का

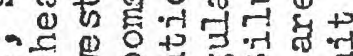

य

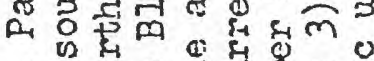

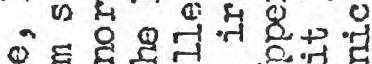

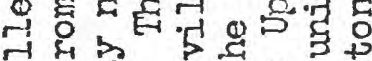

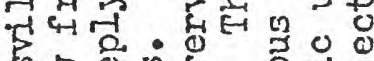

है

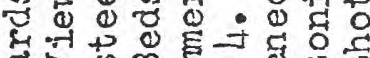

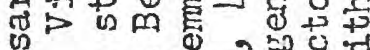
: ๓ न 0 मे 00 व

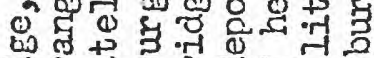

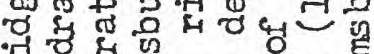
क्य एक

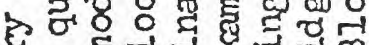

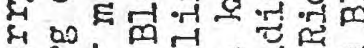

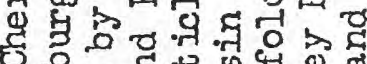
है 0 दी

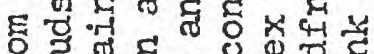
क ०. का का मे

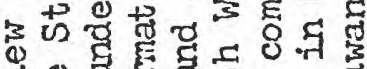
ते छु

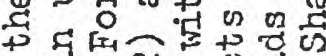
0 न

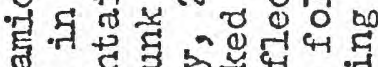
की क

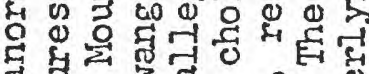
त 350

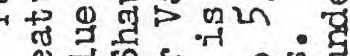
屯ै ति के

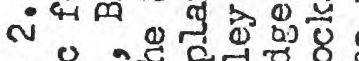

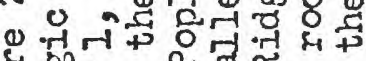

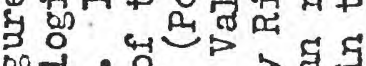

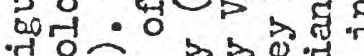
न प० क्षे

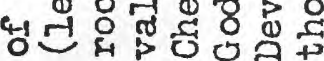


deposition of a thick synorogenic flysch sequence (Nartinsburg Fornation) followed by a thick molasse during Silurian and Early Devonian time (predominantly continental clastic wedge overlain by shaliow-marine sediments). Basin deepening began again in later Early Devonian time culminating with another thick clastic wedge (Catskill Fornation north of the quadrangle).

The topography had a profound effect on the direction of movement of the Wisconsin glacier, as well as the manner of its retreat and the deposits that were formed. T11I and stratified drift of Wisconsin age and till of possible Illinoian age are common in the quadrangle. Wisconsin deglaciation occurred by northeastward retreat and by stagnation. A conspicuousterminal moraine marks the limit of Wisconsin ice movement. Lake Sciota was dammed between the retreating ice, the moraine, and the surrounding ridges north of Godfrey Ridge. Several deltas mark ice stand positions during the retreat of the ice. Lake-bottom and kame deposits are locally common in Cherry Valley. South of Kittatinny Mountain, on the other hand, melt water was freely discharged to the south.

It is concluded that the wind and water gaps in the Stroudsburg quadrangle and surrounding areas are structurally controlled; specifically, they are located where folds die out in short distances, where folding is locally more intense, or where resistant rocks dip steeply and have a narrow width of outcrop. This conclusion is contrary to the concept of regional superposition.

Field work in the Stroudsburg quadrangle was done in 1961 to 1963 and was field checked in 1968. It is part of a larger bedrock and 
surficial mapping study by the U.S. Geological Survey involving all or parts of eight $7 \frac{1}{2}-m i n u t e$ quadrangles (Stroudsburg, East Stroudsburg, Portland, Saylorsburg, Wind Gap, Kunlletow, Palmerton; and Lehightonthe last five done in cooperation with the Pennsylvania Geological Survey), and also includes stratigraphic studies of Upper Silurian and Lower Devonian rocks of northeastern Pennsylvania, New Jersey, and southeastermost New York in association with A. G. Epstein and members of the New Jersey Geological Survey. Some data included herein are derived from those areas outside the Stroudsburg quadrangle. Much of these data are published, including discussion of the geologic relations in eastern Pennsylvania between Delaware Water Gap and Iehigh Gap (Epstein and Epstein, 1967, 1969), the stratigraphy of the Martinsburg Formation (Drake and Epstein, 1967) and Upper Silurian and Lower Devonian rocks (Epstein and others, 1967), the oxigin of wind and water gaps in the Stroudsburg area (Epstein, 1966), the surficial geology of the Stroudsburg quadrangle (Epstein, 1969), and the bedrock geology of the Bangor quadrangle (Davis and others, 1967), and the Portland and Belvidere quadrangles (Drake and others, 1969). . 


\section{BEDRCCK STRATIGRAPHY}

The stratigraphic sequence in the Stroudsburg quadrangle consists of more than 17,000 feet of shale, siltstone, sandstone, conglomerate, Iimestone, and dolomite ranging from Middle Ordovician to Middle Devonian in age (see pl. I). Thick drift covers all the area underlain by the Poxono Island Formation and upper part of the Blnomsburg Red Beds, but their characteristics are knom from exposures in the Saylorsburg quadrangle to the west and from drilling by the U.S. Arrny Corps of Engineers in the Bushkill quadrangle to the northeast. Large areas of the Martinsburg Formation as well as the lower part of the Brodhead Creek Member of the Marcellus Shale are similarly covered.

\section{ORDOVICLAN}

\section{Martinsburg Formation}

The name Martinsburg was first used by Geiger and Keith (1891), and the formation was first adequately described by Keith (1894) for partily calcareous shales exposed near Martinsburg, West Virginia. The belt of rock was traced by subsequent workers into the Delaware Valley where it consists of slate and graywacke between 9,800 and 12,800 feet thick, is generally considered to be Middle Ordovician (Trenton) to Late Ordovician (Maysville) in age, and was subdivided into three members (surmarized by Drake and Epstein, 1967).

For nearly a century there has been disagreement on the internal subdivision of the fartinsburg Formation in eastern Pennsylvania and New 
Jersey. The arguments have been based on faunal and st ructural evidence. Those workers who have investigated the area generally west of the Lehigh River believe that the Martinsburg is divisible into two parts: a lower shale unit and an upper sandstone unjt (Stose, 1930; Ward, 1937; Willard and Cleaves, 1939; Miller and others, 1941; Willard, 1943; Moseley, 1950), In the Delaware Valley and New Jersey a twofold division was likeiise interpreted by Sanders (in Lesley, 1883), Lesley (1892), and Lewis and Kümmel (1915). Investigations in the slate belt between Delaware and Iehigh Rivers in Pennsylvania have generally yielded a threefold breakdown: two slate belts separated by a middle sandstone-bearing unit (Merriman, 1898; Dale and others, 1906, 1914; Peck, 1908; Miller, 1925; Behre, 1924, 1933; and Miller and others, 1939). Behre's work is the most detailed in the slate belt, but his threefold interpretation was not accepted on the most recent State geologic map (Gray and others, 1960). Detailed stratigraphic and structural evidence presented later by Drake and Epstein (1967) showed that the Martinsburg of the slate belt: can be divided into three mappable members in alnost the same way as defined by Behre. These are, in ascending order, the Bushkill, Ramseyburg, and Pen Argyl Members.

Differences in stratigraphic interpretation have led to various thickness estimates. Those who believe in a twofold interpretation have estimated that the Martinsburg is as thin as 3,000 feet (Stose, 1930), whereas those who believe in three members have estimated thicknesses in excess of 10,000 feet (Behre, 1933; Drake and Epstein, 1967).

The differences in stratigraphic interpretation have generally been blamed on complicated structure and poor exposures in the slate belt. However, mapping in the Stroudsburg and adjoining quadrangles has shown 
conclusively that there are three members. All geologists agree that a basal slate merber (Bushkill) is overlain by a sandy member (Ramseyburg) However, those who believe in two members maintain that the upper member (Pen Argyl) of the threefold school is actually the lower member repeated by folding in a large, upright regional syncline and that it dips underneath the middle member. Thus, the relationships between the midale and upper members is of initial injortance.

Southwest of the Stroudsburg quadrangle, where the Pen Argyl dips south at its contact with the Ranseyburg, it is overturned, as indicated by numerous sedimentary structures (i.e., graded bedding and crossbedding), bedding-cleavage relations, and geonetry of folds. In the Stroudsburf quadrangle the contact dips to the north, the beds are upright as shom by sedimentary structures, and the Pen Argyl is clearly younger than the Ramseyburg.

In support of his twofold hypothesis, Stose (1930, p. 655) argued that in the ravine at Slateford, near Delaware River (Portland quadrangle, pl. 1), calcareous sandstones underlie slates that Behre (1933) placed in his upper member. Stose believed, on the contrary, that the sandstones are near the base of the lonter shale member because fossils collected 20 miles to the southwest along strike were considered by Urich to be older than Pulaski (Haysvillian), hence older than Behre's middle sandy member which Stose identified as the upper sandy member. As added proof, Stose (1930) believed that a possible outcrop of limestone with "Canadian" fossils beneath the drift in New Jersey, across the river from Slateford, showed that the calcareous sandstones in the ravine are basal. Martinsburg and immediately overlie the 
Iimestones brought up in an anlicline.

Stose's reasoning is in error. Behre (1933, p. 142) maintained that the fossils identified by Ulrich are too poorly preserved to be of stratigraphic value. The sandstones in the ravine are basal Ramseyburg, not basal Bushkill, and there is no limestone outcrop immediately across the river. Behre (1933) had erred slightly by including the slate in the quarries in his upper slate member (Pen Argyl Miember). Actually, the quamies are in a slate belt or "run" within the Ramseyburg Member. Behre had failed to recognize that the Pen Argyl-lamseyburg contact trended more northerly than he believed and was overlapped by the Shawangunk Formation just west of Delaware Water Gap. As a consequence, he (1933, pl. 24) mapped a thinned middle member and was obliged to map an unnecessary fault within it.

Thus, mapped structural relations demonstrate that the Pen Argyl overlies the Ramseyburg. There is also added stratigraphic supporting evidence. If the upper member were the lower member repeated by folding, the two units should be lithically similar. Such is not the case, as will be discussed below. In addition, quarrymen in eastern Pennsylvania have long been aware of two distinctly different slate belts in eastern Pennsylvania: a "soft-vein" belt to the north and a "hard-vein" belt to the south. These are not belts repeated by folding; Stose's (1930) regional syncline does not exist in this area (Drake and Epstein, 1967).

It should be pointed out that the two-member interpretation in the Delaware Valley and New Jersey by Sanders (1883), Lesley (1892), and Lewis and Kummel (1915) is partly correct because the Pen Argyl Member is neither exposed at nor for several miles east of Delaware 
Water Gap. It is possible that the upper member does not reappear in New Jersey, although Offield (1967) reports a similar three-unit sequence in Ordovician clastic rocks in southeastern New York. Bushlill Member

The Bushkill lember was named by Drake and Epstein (1967) for exposures along Bushkill and Little Bushkill Creeks in the Wind Gap quadrangle, Northampton County, Pennsylvania. It is exposed in a few localities in the southeast corner of the Stroudsburg quadrangle where it consists of dark- to medium-gray thin-bedded to laminated carbonaceous slate, claystone slate, and thin interbeds of grayracke siltstone in upward-fining cycles Beas do not exceed 6 inches in thickness and rarely exceed 1 inch, in sharp contrast to the much thicker bedàed Pen Argyl Member. No fossils have been found in the Bushkill liember. The base is not exposed in the Stroudsburg quadrangle, but to the south it is gradational into the Jacksonburg Limestone of Middle Ordovician age. It is about 4,000 feet thick. Ramseyburg Member

The Ramseyburg Hember is characterized by graywacke that makes up 20 to 25 percent of the unit. It vas named for representative outcrops near Ramseyburg, Portland quadrangle, Warren County, New Jersey (Drake and Epstein, 1967). The graywacke occurs as siltstone to medium-grained sandstone in beas ranging from laminae to more than 4 feet thick. Typically, the grajwacke beds have an erosional base and grace up into mediun-gray slate which in turn passes into grayish-black carbonaceous slate. The slate makes up most of the Ramseyburg, occurs in beds less than 1 inch to more than 10 feet thick, and is well exposed in many 
slate quarries in the vicinjty of East Bangor (fig. 3).

Those parts of the Nartinsturg that have more than 30 percent graywacke are shown as "Onng" in plate 1. They range from 250 to 900 feet thick and alternate with equally thick slate-dominated intervals or "runs," one of which, the Bangor beds of Behre (1933), is still actively quarried. Behre included the Bangor beds in his upper slate menber, but a prominent interval of graywacke overlies the Bangor beds and forms the top of the Ramseyburg Hember as defined in the Stroudsburg quadrangle.

Graywacke beds are generally poorly exposed because they are calcareous and readily leached. Characteristically, they hold up low hills and litter the ground with "tobacco brown" (light brown to moderate yellowish brown) angular fragrents several inches long. Graded bedding, parallel and ripple laminations, and convoluted bedding is common in the graywacke. Rarely, comminuted fossil debris is found. These characteristics, along with sole marks, have led Van Houten (1954) and MicBride (1962) to the conclusion that the grayracke was emplaced by turbidity currents in deep water where the "normal" sediment was pelagic mud.

The Ramseybure Henber is about 2,800 feet thick. Its gradational contact with the underlying Bushkill Member is placed at the lowest prominent graywacke bed, generally more than I foot thick, in the section.

Pen Argyl Hember

The slate quarries near Pen Argyl, Wind Gap quadrangle, Northampton County, Pennsylvania, are tho type locality for the Pen Argyl Kember 


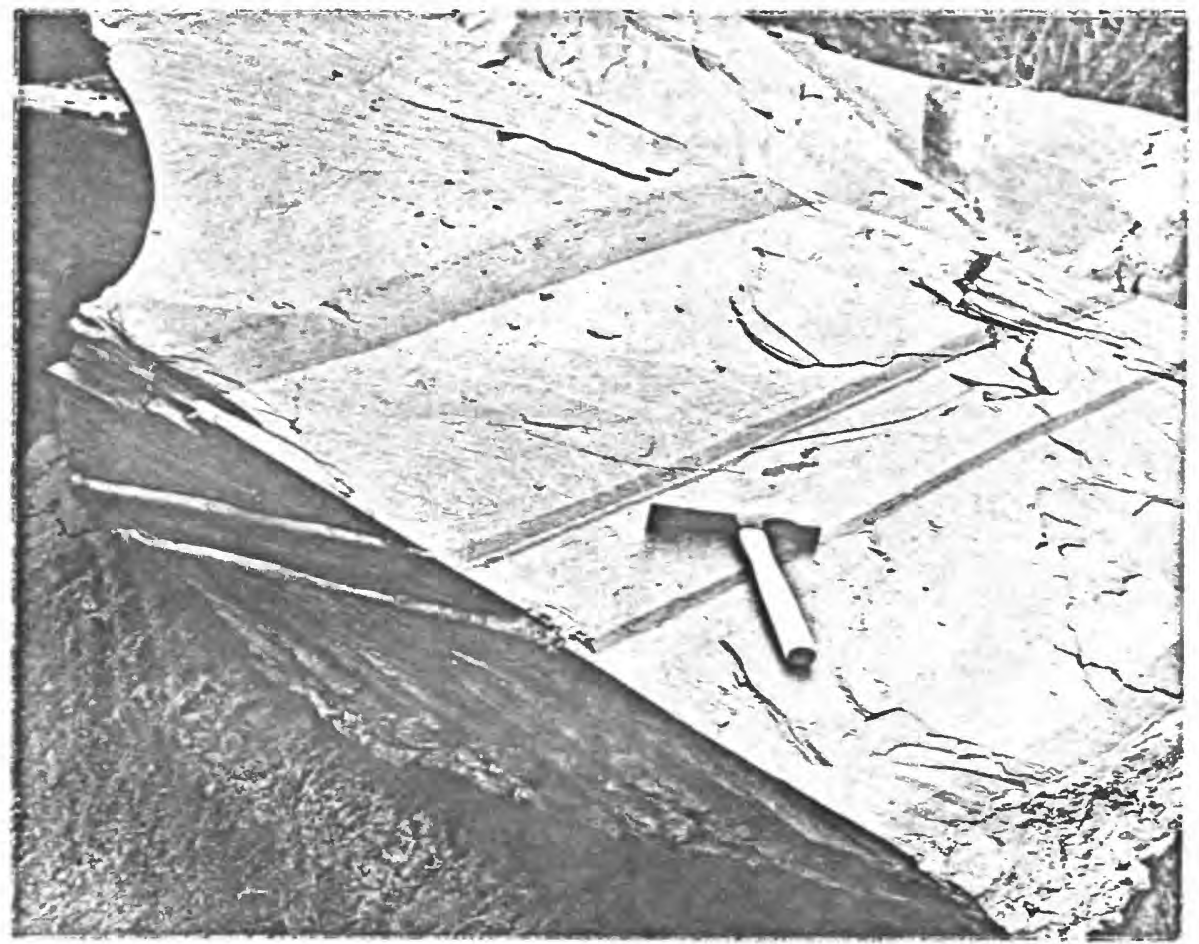

Figure 3. Gray slate beds, more than 1 foot thick, and thinner carbonaceous beds in slate block at Capitol Slate Co. quarry, East Bangor, $\mathrm{Pa}$. Hamner rests on cleavage; bedding djps to left. Note white calcite and quartz in bedding-plane slickensides on underside of block. Cleavage deforms the slickensides, although this is not apparent in photograph. 
(Drake and Epstein, 1967). The Pen Argyl Hember consjsts of dark-cray, thick - to thin bedded (beds more than 15 feet thick are common), evenly bedded claystone slate rhythrically interbedded with grayish-black carbonaceous slate. Occasional graywacke beds as much as 4 feet thick mark the base of fining-upward sequences as they do in the underlying Ramseyburg Member. The Pen Argyl is probably more than 5,000 feet thick in the Stroudsburg quadrangle and is unconformably overlain by the Shawangunk Formation. Its lower contact is the top of the uppermost prominent graywacke bed in the upper graywacke interval of the Ramseyburg Member. The Pen Argyl disappears under the Shawangunk just west of Delaware water Gap and no exposures are known in the Portland quadrangle west of the gap.

Age of the Martinsburg Formation

The Martinsburg Formation has been regarded as Middle Ordorician (Trenton) to Late Ordovician (Maysville) in age (see sumary by Drake and Epstein, 1967). The Bushkill Member rests conformably on the Jacksonburg Limestone). The upper Jacksonburg is early Barnveldian (= middle Trenton), based on conodont studies by Barnett (1965). In 1969, I discovered graptolites in the upper part of the Pen Argyl Member at Lehigh Gap, Palmerton quadrangle, Pennsylvania. The se were identified by W. B. N. Berry of the University of California, Berkeley (written commun., 1969, 1970). The graptolites are indicative of the upper subzone (Climacograptus spiniferus subzone) of zone 13 (Orthograptus truncatus intermedius zone) which is probably early Edenian. Thus the Martinsburg ranges from late(?) Barrveldian to early Edenian and is more restricted than previously reported. 
Petrography

Besides the gross lithic differences rentioned above, the slates and sandstones (graywackes) vary little throughout the Martinsburg Formation. Grain size ranges from less than .005 in clay slates to about $0.3 \mathrm{~m}$ in medium-grained sandstones.

As determined by semiquantitative X-ray diffraction analyses, the dominant minerals in three random samples of slate in the Stroudsburg quadrangle are quartz ( $32-52$ percent), muscovite ( $25-55$ percent), chlorite (10-25 percent), and feldspar ( $1-3$ percent). Calcite is variable as seen in thin section. Probably much of the calcite is ankeritic, judging from the brown stain that develops on weathering. Pyrite and black opaque minerals are commonly scattered throughout all samples. The grayish-black slates that form the top of upward-fining cycles are carbonaceous, less calcareous, and finer grained than the dark-gray slates.

Quartz grains in the slate are angular. They are stretched in the direction of cleavage and the sides that are perpendicular to cleavage are ragged, evidently due to pressure solution. Finer grained quartz, chlorite, muscovite, calcite, and iron-oxide dust have grown in the pressure-shadow areas (fig. 4 ).

Chlorite and muscovite form a large part of the groundmass of the slate. They are lath shaped and some of the se grains lie parallel. to the cleavage, although many grains do not. These groundmass minerals are difficult to examine optically because of their small size. Larger grains of intergrom chlorite and muscovite are as much as 50 times the average grain size of the groundmass minerals and are believed to be porphyroblasts (fig. 4). The chlorite has blue and reddish-brown 


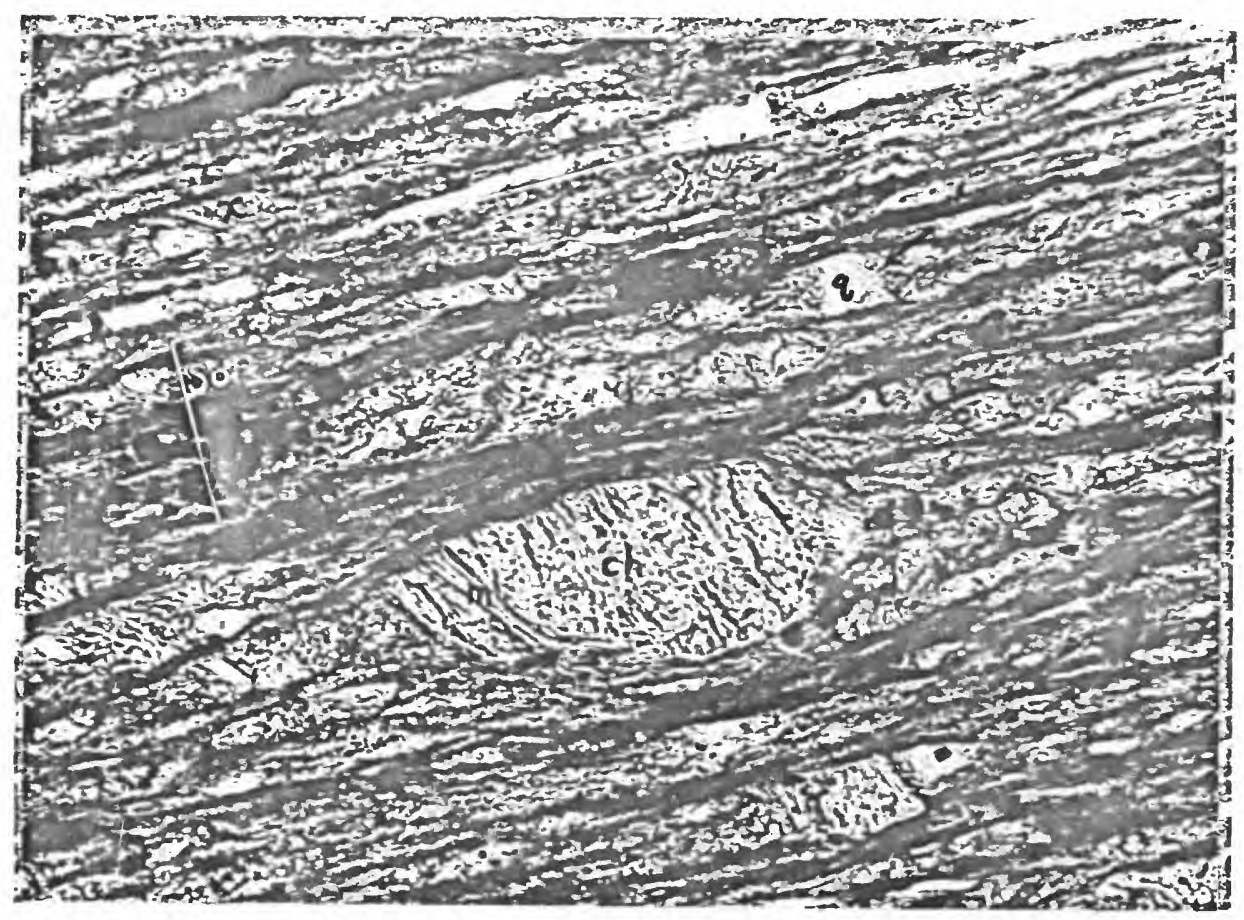

Figure 4. Photomic rograph (plane-polarized light, X 275) of dark-gray slate, Pen Argyl Member of the liartinsburg Formation, from dumps of inactive New Peerless slate quarry, 2,800 feet southeast of North Bangor, Pennsylvania. Bedding $\left(\mathrm{s}_{\mathrm{o}}\right)$ lies at an angle of about $90^{\circ}$ to slaty cleavage $\left(S_{1}\right)$. Quartz $(q)$ is angular with growths of smaller muscovite, quart $\bar{z}$, chlorite, and calcite in pressure-shadow areas (arrow). Several porphyroblasts of intergrown chlorite (ch, penninite) and muscovite (n) are more than 10 times the average grain size of the groundmass. The porphyroblasts are elongated in the direction of cleavage, their mineral cleavage is at a high angle to the slaty cleavage, and the mineral cleavage lies at a slight angle to bedding. Many platy minerals are parallel to cleavage, but some (at $x$, for example), lie at appreciable angles to cleavage. Opaque minerals, mostly pyrite and probably magnetite, are scattered throughout. 
interference colors and is identifjed as pennine.

Carbonaceous matter forms black streaks in cleavage planes. An occasiona]. grain of microcline can be identified in thin section, but the dominant feldspar is albite, as indicated by X-ray analysis. Albite has not been definitely identified in thin section because of the fine grain size of the slates.

The slaty cleavage is believed to have developed under conditions of low-grade metamorphism. This has important regional structural significance and will be discussed under the section on structural. geology.

Chemical analyses of typical slates and graywackes from the Martinsburg Formation are given in table 1. The relatively lor silica content, Iow silica/alumina ratios, and low alumina/soda ratios as shown by the chemical analyses, as well as the text ural and mireralogical characteristics of these rocks, particularly the sandstones, show that they are an immature suite (compare with more mature rocks of the Shawangunk Formation in table 2). Further details of mineralogy and chemical composition are given by Behre (1933). Megascopically, graywacke is hard, medium-gray to medium-dark-gray, micaceous, poorly sorted sandstone and siltstone. Both Iithic and feldspathic graywackes are comnon (classification of Pettijohn, 1957). As shown in thin section (figs. 5-7), the matrix consists predominantly of silt-and clay-size nuscovite, quartz, chlorite, and calcite, with minor opaque minerals and carbonaceous matter. Floating in the matrix, which ranges from about 25 to 50 percent of the rock, are angular grains of quartz (probably 30 to 40 percent), feldspar (1-10 percent; predominantly plagioclase and mostly albite-andesine), muscovite and chlorite 
Table 1. Typical chemical analyses of slate (samples 1-3) and graywacke (samiles 4 and 5 ) from the lfartinsburg Formation. Samples 1, 4, and 5 are rapid-rock analyses by P. Elmore, G. Chloe, J. Kelsey, S. Botts, H. Smith, J. Glenn, and L. Artis, U.S. Geological Survey. Samples 2 and 3 are analyses from Behre (1933, p. 174).7

\begin{tabular}{lccccc} 
& 1 & 2 & 3 & 4 & 5 \\
\hline $\mathrm{SiO}_{2}$ & 50.2 & $57.1_{4}$ & 55.56 & 59.2 & 69.9 \\
$\mathrm{Al}_{2} \mathrm{O}_{3}$ & 16.4 & 17.08 & 20.57 & 8.4 & 12.7 \\
$\mathrm{Fe}_{2} \mathrm{O}_{3}$ & 2.0 & & & 1.5 & 2.0 \\
$\mathrm{FeO}$ & 4.4 & 5.76 & 6.18 & 3.2 & 4.1 \\
$\mathrm{MgO}$ & 2.8 & 3.29 & 2.76 & 2.6 & 2.4 \\
$\mathrm{CaO}$ & 7.6 & 3.95 & 3.27 & 9.6 & .36 \\
$\mathrm{Na}_{2} \mathrm{O}$ & .63 & 1.05 & 1.12 & 1.5 & 1.3 \\
$\mathrm{~K}_{2} \mathrm{O}$ & 3.8 & 3.11 & 2.95 & 1.5 & 2.6 \\
$\mathrm{H}_{2} \mathrm{O}-$ & .19 & & & .10 & .29 \\
$\mathrm{H}_{2} \mathrm{O}+$ & 3.8 & & & 1.6 & 3.0 \\
$\mathrm{TiO}_{2}$ & .80 & .53 & .66 & .48 & .84 \\
$\mathrm{P}_{2} \mathrm{O}_{5}$ & .16 & & & .12 & .15 \\
$\mathrm{MnO}^{2}$ & .10 & & & .17 & .05 \\
$\mathrm{CO}_{2}$ & 6.6 & n.d. & n.d. & 9.5 & .05 \\
\hline Total & 99.48 & & & 99.47 & 99.74 \\
\hline
\end{tabular}

1. Slate, middle part of the Pen Argyl Member, abandoned Peters slate quarry, 5,000 feet north-northeast of Walnutport, Palmerton quadrangle, Northampton County; $\mathrm{Pa}$.

2. Hard slate, Ramseyburg Member, Consolidated No. I-Star quarry (ncrr Capitol Slate Co.), East Bangor, Pa., Stroudsburg quadrangle. Note: n.d., not determined; loss on ignition 9.75 percent.

3. Soft slate, Ranseyburg Meriber, Consoliciated No. I-Star quarry (now Capitol Slate $\mathrm{Co.}_{.}$, East Bangor, Pa., Stroudsburg quadrangle. Note: n.d., not determined; loss on ignition 9.50 percent; sulphur 0.76 percent.

4. Graywacke, Pen Arcyl Member, abandoned Lehigh Gap slate quarry, 4,500 feet north of Slatington, Pa., Palmerton quadrangle. Figure 5 is photomicrograph of sample.

5. Graywacke, Pen Argyl Member, 150 feet below contact with Shawangunk Formation, Lehigh Gap, Pa., Palnerton quadrangle. Figure 6 is photomicrograph of sample. 


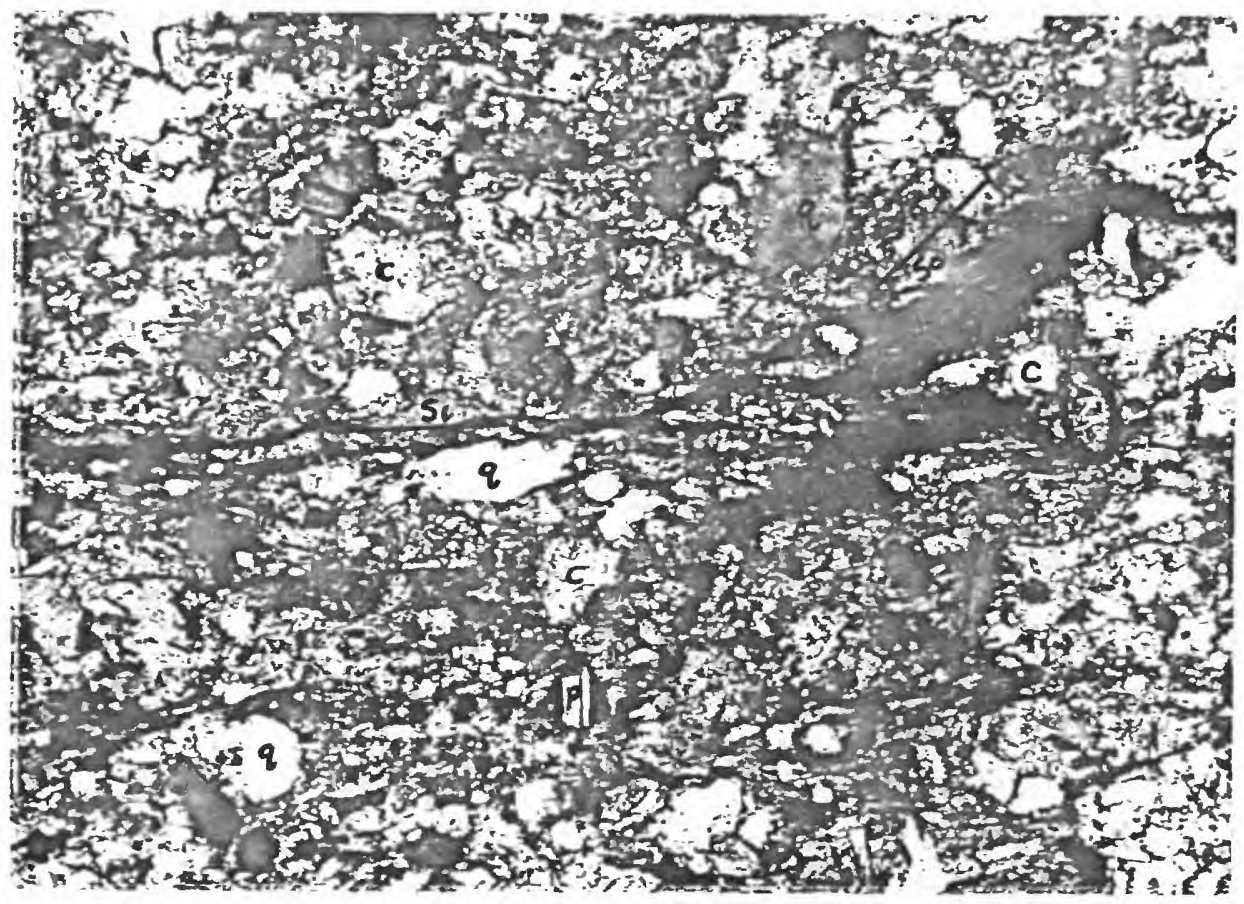

Figure 5. Photomicrograph (crossed polarizers, X 110) of medium-dark-gray, fine- to mediuri-grained lithic (calcitic) graywacke, Pen Argyl liember of the Martinsburg Formation, abandoned Lehigh Gap slate quarry, 4,500 feet north of Slatington, Pa., Palmertion quadrangle. The framework grains are as much as $0.2 \mathrm{~mm}$ long and consist of quartz ( $q, 35$ percent); irregular discrete grains and lesser rhombs of calcite (c, 15 percent); plagioclase feldspar ( $p, 1$ percent); muscovite (m) and chlorite (about 2 percent); and rare zircon (z). The grouridmass is composed of finer grained muscovite, quartz, chlorite, and calcite, and lessex carbonaceous matter and opaque minerals. Note cleavage $\left(\mathrm{S}_{1}\right)$ which is at an angle of $25^{\circ}$ to bedding $\left(S_{0}\right)$. Chemical analysis of this sample is given in table 1 , column 4. 


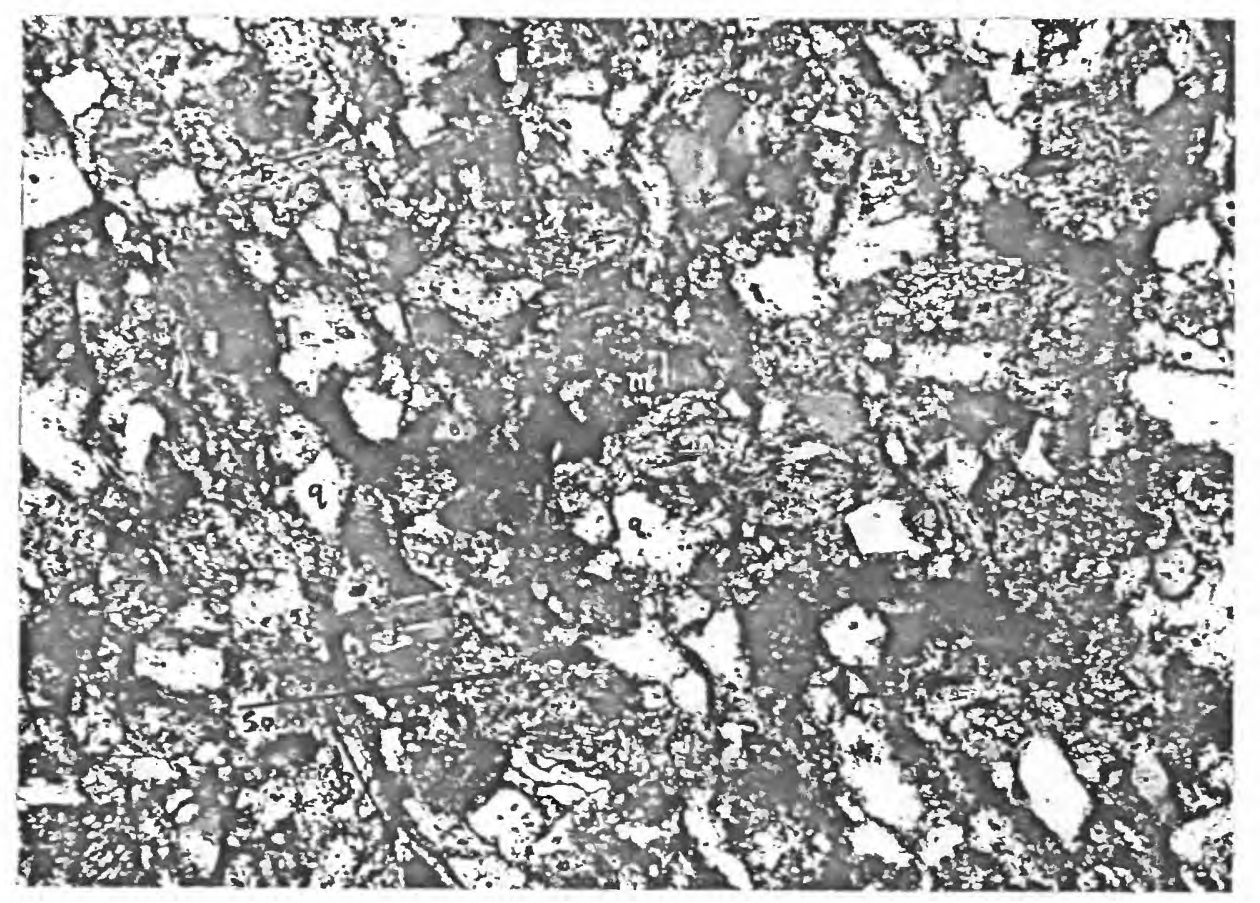

Figure 6. Photomicrograph (crossed polarizers, X 110) of lithic grayvacke, Pen Argyl liember of the Martinsburg Formation, 150 feet below the contact with the Shawangunk Formation, Lehigh Gap, Palmerton quadrangle, Pennsylvaria. The framework minerals are quartz (q, 34 percent), argillite rock fracments ( $r, 9$ percent), plagioclase feldspar ( $p$, 4 percent), and microcline $(\mathrm{m})$ and or thoclase ( 2 percent), in a finegrained matrix of muacovite, quartz, and chlorite ( 47 percent) with minor limonite and other opaque minerals. Detrital biotite (b), partly altered to chlorite, makes up less than 1 percent of the rock. Bedding $\left(\mathrm{s}_{0}\right)$ makes an ancle of $60^{\circ}$ to cleavage $\left(\mathrm{s}_{1}\right)$. Chemical analysis of this sample is given in table 1 , column 5 . 


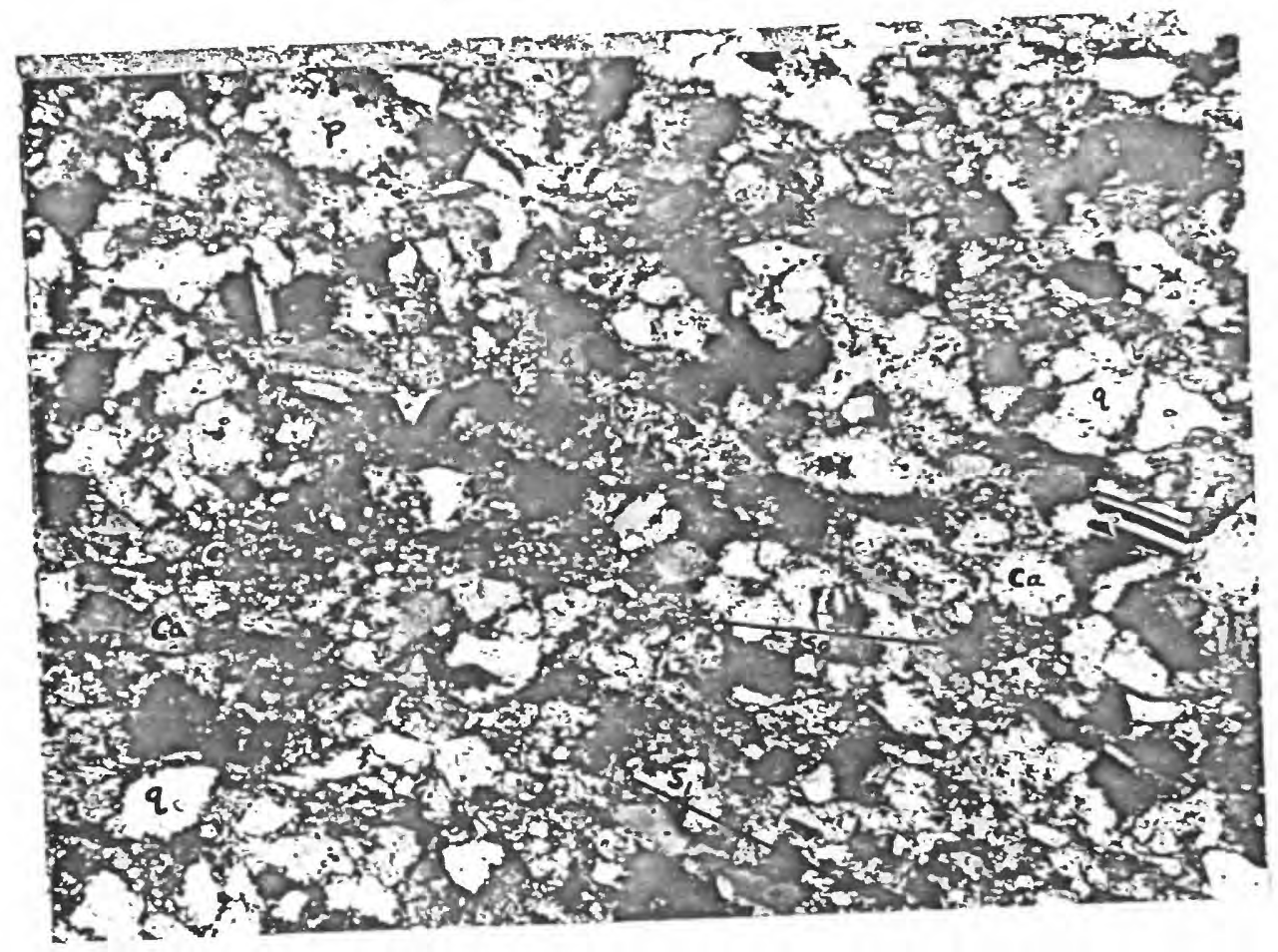

Figure 7. Photomicrograph (crossed polarizers) of fine-grained feldspathic graywacke, Ramseyburg Kember, Slateford Creek, Portland quadrangle. Matrix ( 36 percent) consists of a paste of muscovite, chlorite, quarta, calcite, and opaque matter. The framewor'k grains are quartz ( $q, 43$ percent), feldspar (mostly plagioclase, $p, 7$ percent), rock fragments (shale, 2 percent), and less than 3 percent chert (c), zircon, chlorite, and muscovite. Very rare detrital biotite in the rock, partly altered to chlorite, is not present in this photograph. Carbonate minerals, probably sideritic calcite (Ca), make up about 9 percent of the rock. Some calcite appears as discrete grains, but much is recrystallized and envelops and replaces other grains. Bedding $\left(S_{0}\right)$ is at an angle of $17^{\circ}$ to cleavage $\left(S_{1}\right)$. 
(probably averaging about 5 percent), and calcite (probably $I$ to 15 percent). The calcite in many thin sections appears to be detrital because it occurs as discrete irregular grains with the same range in grain size as detrital quartz and does not generally envelop and form a cement around other grains. Thus, if the calcite is considered as rock fragments, these sandstones are lithic graywackes (fig. 5). Rock fragments of other types, such as shale and siltstone, are rare in calcitic graywackes and common in some noncalcitic types (fig. 6).

- Feldspathic graywackes are also common (fig. 7). In outcrop, intraclasts of shale (now slate) are common. These are as much as several inches in length. Heavy minerals, such as zircon and rutile, were noted. No amphibole or pyroxene was seen. liany graywacke beds have framework minerals that are dominently silt size. These are grayracke siltstones and generally overlie graywacke sandstones and grade up into slates.

\section{SILURIAN}

\section{Shawangunk Formation}

Sandstones and conglomerates in southeastern New York were first named the Shawangunk Conglomerate by Mather (1840). In eastern Pennsylvania, these rocks were called Levant by Rogers (1853), Oneida and Medina by White (1882), and first termed Shawangunk by Grabau (1909). Historical summaries are given by Schuchert (1916) and Swartz and Swartz (1931).

Swartz and Swartz (1931) traced the Tuscarora Sandstone and Clinton Formation eastward from central Pennsylvania to Delaware Water Gap where they lose their identity and merge into the Shawangunk Formation. Petailed mapping by Epstein and Epstein (1967, 1969) shows that the 
Clinton Formation of Swartz and Swartz (1931) can be traced from the Lehigh Gap area eastward to Delaware Water Gap where it forms a tongue - in the Shawangunk (fig. 8). Similarly, the Tuscarora of Swartz and Swartz (193I) can be traced beneath the clinton. Because the name Shawangunk has priority over the Tuscarora (named by Darton in 1896) and Clinton (named by Conrad, 1842), the Shawangunk Formation is used in the area of this report for rocks above the Hartinsburg Forriation and below the Bloomsburg Red Beds. Three mambers are herein defined. They are, from bottom to top, the Minsi, Clinton, and Tammany Members.

The Shawangunk is about 1,390 feet thick along U.S. Interstate 80 in Delaware Water Gap. Because of the extremely irregular upper contact with the Bloomsburg Red Beds, to be discussed later, the thickness can be as great as 2,100 feet. This may account for the wide variation of reported thiclmesses at the gap: Chance (1882), 1,565 feet; Grabau (1913), 1,900 feet; Swartz and Swartz (1931), 1,823 feet.

Minsi Member

The Minsi Member of the Shavangunk Formation is named for exposures In Delaware Water Gap, Warren County, N. J. (fig. 9), where it contains quartzite $^{I}$, conglonerate, and minor siltstone. It forms a cliff face along the south slope of Blue and Kittatinny Mountains. The Minsi Hember is 303 feet thick at its type section (measured section 1) and consists of light-gray to medium-dari-gray, medium- to coarse-grained,

1 Quartzite is used in this report for a dense. sandstone that is Eenerally cemented by silica or hich has interlocking quartz grains. The rock breaks across the grains. Quartzite does not necessarily imply metamorphism. "Sandstone" and "quartizite" are used interchangeably in this report, where applicable. 


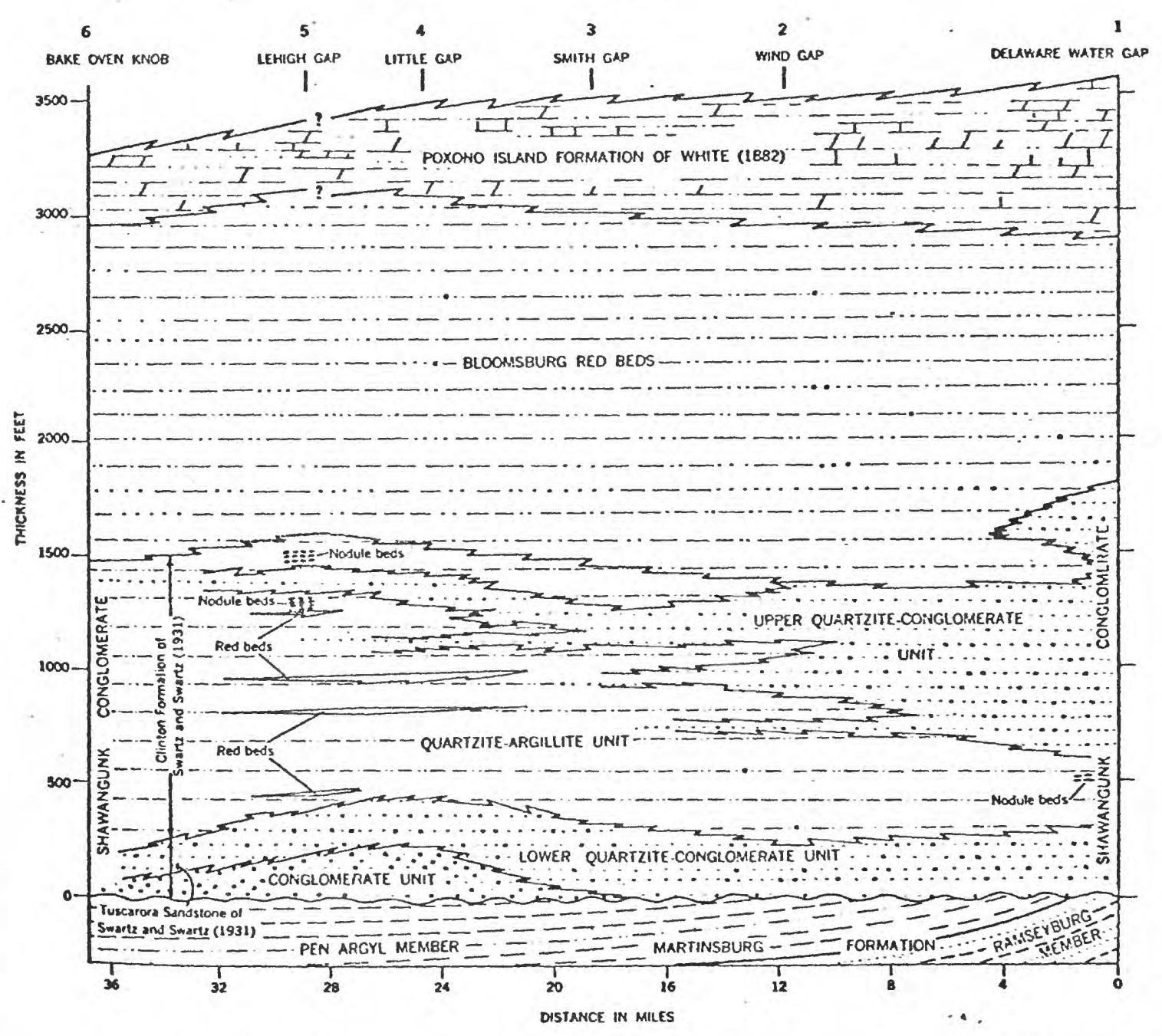

Figure 8. Stratigraphic section of the Shawangunk Conglomerate (Shawangunk Formation in this report), Bloomsburg Red Beds, and Poxono Island Formation from Delaware Water Gap in the Stroudsburg and Portland quadrangles, to Bake Oven Knob, just south. of the Lehighton quadrangle. From Epstein and Epstein, 1969. The lower quartziteconflomerate unit is herein named the Minsi Hember, the quartziteargillite unit is the Clinton Member, and the upper quartziteconglomerate unit is the Tamnany liember. 


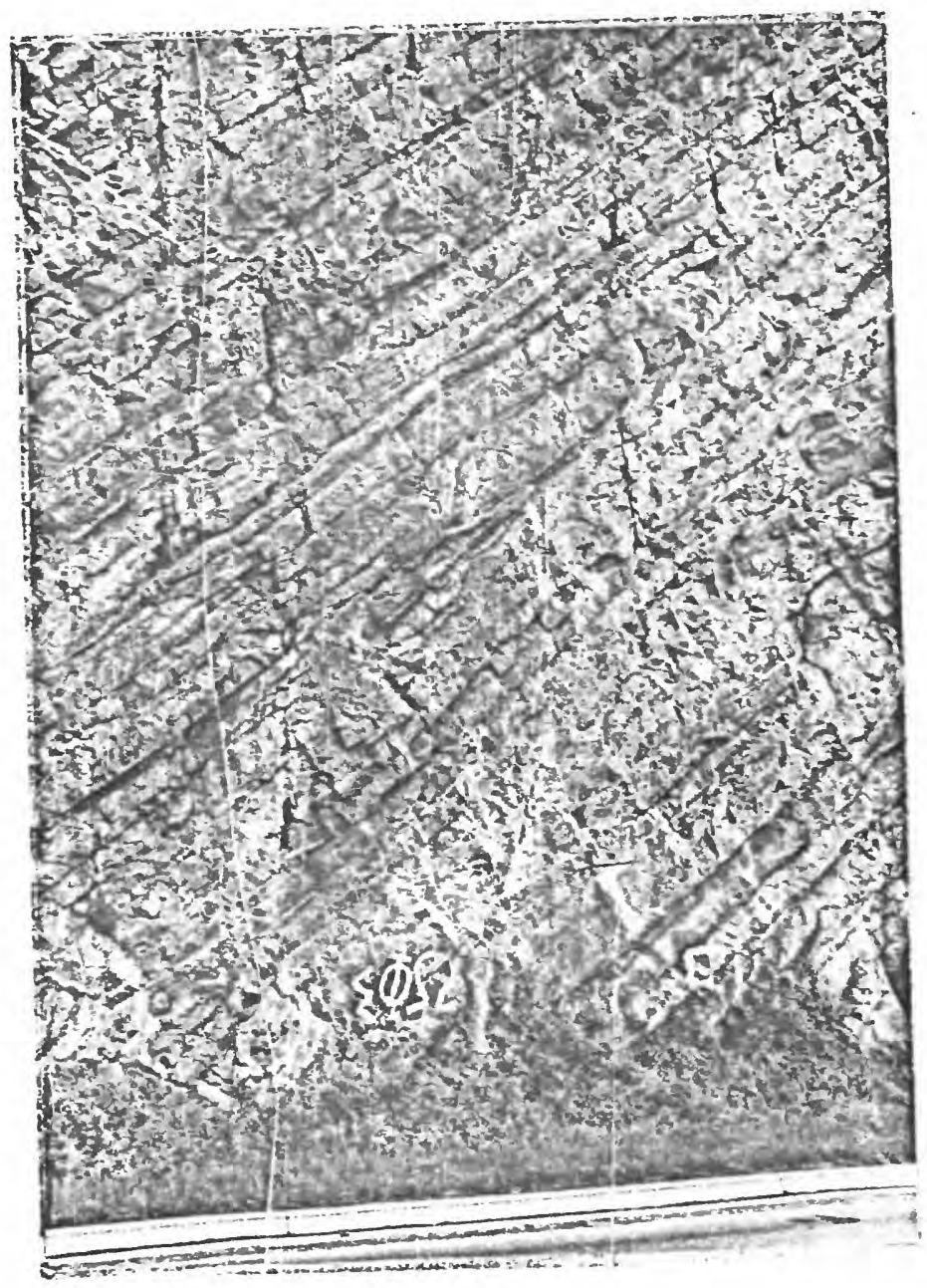

Figure 9. Interbedded quartzite and conglomerate in the Kinsi Hember of the Shawangunk Formation at the type section, Delaware Water Gap, Warren County, N. J. Note channeled bases of many of the beds. 
crossbedded to planar-bedded, limonitic, pyritic, uneverly to moderately evenly bedded, thin- to thick-bedded quartzite, conglomeratic quartzite, and quartz-, chert-, and shale-pebble conglomerate (quartz pebbles are as much as 2 in. long).

About 7 percent of the member is made up of dark-zray irregularly bedded to evenly laminated siltstone that is locally shaly and mudcracked (fig. 10). The lower contact is not presently exposed in the quadrangle, but Beerbower (1956) described it as abrupt and unconformable on the Martinsburg Formation. No fossils have been found in the Minsi Nember, although Schuchert (1916, p. 546) reports Arthrophycus, probably a feeding burrow, 225 feet above the base in Delaware Vater Gap, and I have observed the same trace fossil in a large block of rock in the retaining wall about 300 feet south of the MartinsburgShawangun's contact along U.S. Interstate 80 in New Jersey.

The sandstones or quartzites of the Hinsi Member are submature (matrix averages about 12 percent of thin sections studied) and contain enough feldspar (about 3-5 percent, predoninantly potash feldspar) and minor rock fragments ( $<I$ percent, mostly shale and siltstone) to be classed as feldspathic sandstones (fig. 11). The chemical composition of a similar submature sandstone (protoquartzite, in this case) from basal beds of the Shawangunk Formation is given in Table 2, sample 1. The heavy-mineral suite in the quartzites is mature (mostly zircon and lesser rutile and tourmaline). These heavy minerals are well rounded to anhedral, and, together with quartz grains that contain minor inclusions of biotite and veriticular chlorite, as well as grains of orthoclase, suggest a reworked sedinentary source with possible minor contributions from a granitic terrane with quartz veins. On the other 


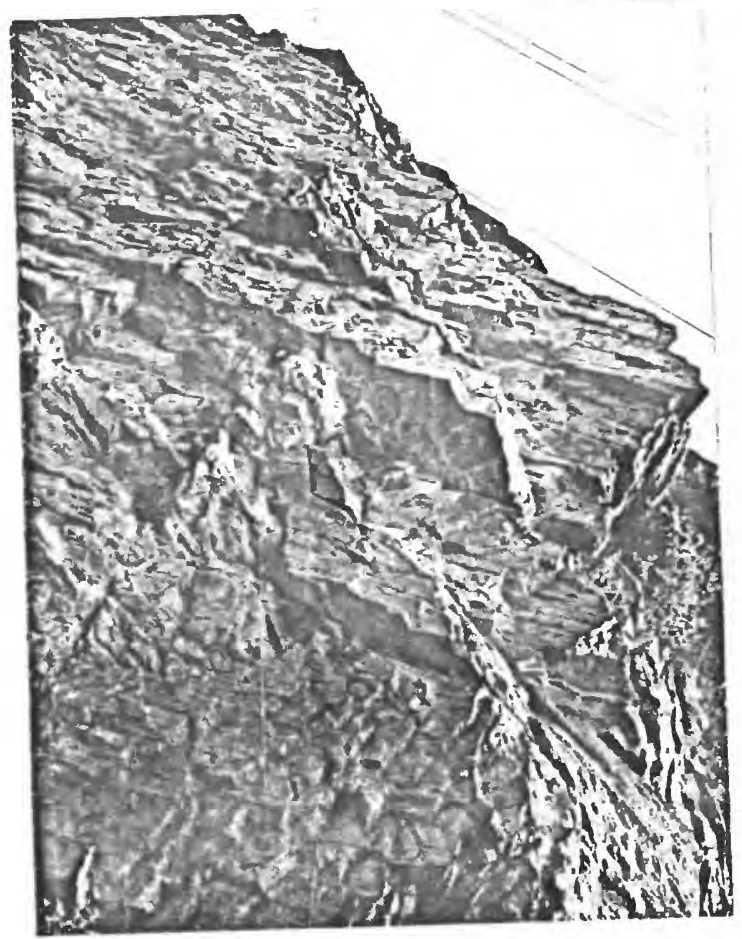

Figure 10. Mud-cracked shaly siltstone, Minsi Merber of the Shawangunk Formation. Underside of bed exposed about 50 feet above U.S. Interstate 80 at south entrance of Delaware Water Gap, Portland quadrangle, Varren County, N. J. 


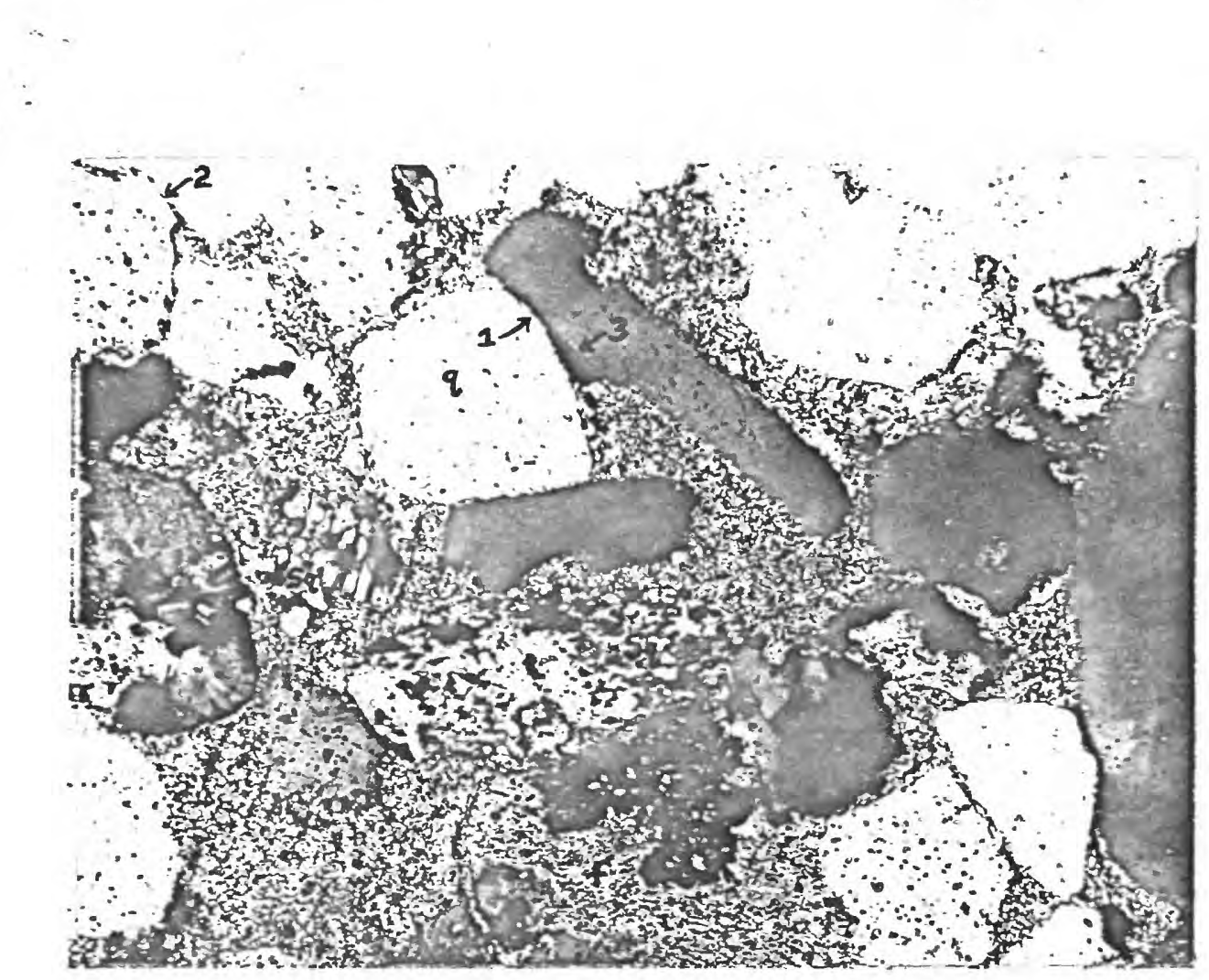

Figure 11. Photomic rograph (crossed polarizers, X 106) of poorly sorted, conglomeratic, fine- to medium-grained feldspathic sandstone from lowest exposed bed of the Minsi Hember of the Shawangunk Formation, Delaware Water Gap, Portland quadrangle, New Jersey (unit 1 of measured section 1). Fiatrix minerals (13 percent) are not readily identified but appear to consist mainly of muscovite and quartz with minor chlorite, Ijmonite, and hematite. Framekork grains are quartz $(q, 80$ percent), as much as $5 \mathrm{~mm}$ long, sericitized potash feldspar ( $f, 5$ percent), partly perthitic and as much as $0.1 \mathrm{~mm}$ long, and chert ( 2 percent). Hany quartz grains are composite with sutured contacts (sq) and indicate a metamorphic or presolved sedimentary quartzite source. Grains are angular to subround. Quartz-grain contacts are straight or concave with (at 1) or without (at 2) a clay coating, or are overgrown with optically continuous quartz (at 3). Abundant vacuole inclusions are in the quartz. Accessory heavy minerals include a mature suite of subhedral to rounded zircon and lesser rutile and tourmaline. One Erain tentatively identified as monazite is included in a quartz erain. Rock fragments (shale) are not common (<I percent). 
Table 2. Typical chomical. analyses of rocks fron the Shawangunk Forration. [liapid-rock analyses by P. Elnore, G. Chloe, J. Kelsey, S. Botts, H. Smith, J. Glenn, and L. Artis, U.S. Geological Surveyr.J

\begin{tabular}{lcccc} 
& 1 & 2 & 3 & 4 \\
\hline $\mathrm{SiO}_{2}$ & 76.6 & 92.2 & 82.9 & 67.3 \\
$\mathrm{AI}_{2} \mathrm{O}_{3}$ & 11.0 & 2.5 & 5.3 & 18.3 \\
$\mathrm{Fe}_{2} \mathrm{O}_{3}$ & .68 & 1.0 & 2.2 & 1.6 \\
$\mathrm{FeO}$ & 2.2 & 1.1 & 3.5 & .76 \\
$\mathrm{MgO}$ & 1.7 & .37 & 1.1 & 1.2 \\
$\mathrm{CaO}$ & .24 & .13 & .81 & .32 \\
$\mathrm{Na}_{2} \mathrm{O}$ & .03 & .00 & .12 & .18 \\
$\mathrm{~K}_{2} \mathrm{O}$ & 3.2 & .26 & .98 & 5.7 \\
$\mathrm{H}_{2} \mathrm{O}-$ & .24 & .09 & .11 & .38 \\
$\mathrm{H}_{2} \mathrm{O}+$ & 2.3 & 1.2 & 1.6 & 2.5 \\
$\mathrm{TiO}_{2}$ & .75 & .28 & .4 .5 & 1.1 \\
$\mathrm{P}_{2} \mathrm{O}_{5}$ & .11 & .00 & .27 & .04 \\
$\mathrm{IinO}^{2}$ & .04 & .04 & .02 & .02 \\
$\mathrm{CO}_{2}$ & $<.05$ & $<.05$ & .05 & .10 \\
\hline Total & $99.09+$ & $99.17+$ & 99.4 .1 & 99.50
\end{tabular}

1. Quartzite, probably protonuartzite, from lower 10 feet of Shawangunk Fomation (conglonerate unit, fig. 8), Lehigh Gap, Palmerton quadrangle, Northaupton County, Pa.

2. Orthoguartiite, Clinton Fomation, Lehigh Gap, Palmerton quadrangle, Carbon County, Pa.

3. Phosphatic quartzite, Clinton riember of the Shawangunk Fornation, Dolaware Water Gap, Portland quadrangle, New Jersey; unit 46 of measured section 1 .

4. Dark-cray siltstone, Hinsi kerber of the Shawangunk Fornation, Delaware Vater Gap, Portland guadrangle, New Jersey; unit Il of measured section 1 . 
hand, composite quartz veirs, rade up of sutured and partly stretched smaller quarta grains, indicate a sedimentary (presolved) quartzite or Iow-grade metamorphic terrane. Conceivably, the total mineral assemblage could have been derived directly from a sedirientary source. Labile minerals, such as hornblende, are extremely rare.

The siltstones, as seen in thin section, consist predominantly of quartz in a muscovite-chlorite matrix. Figure i2 is a photonicrograph of a siltstone containing about 55 percent quartz, 25 percent muscovite, - 15 percent chlorite, and less than 1 percent feldspar (determined by semjouantitative $\mathrm{x}$-ray diffraction analyses).

Clinton Member

The name Clinton was first used by Conrad (1842) for exposures near Clinton, N. Y. The New York Geological Survey now uses the name as a group in central. New York which includes conglomerate, shale, and sandstone (Fisher, 1960). The name has been used extensively throughout the Appalachians and was used by Chance (1882) at Delaware Water Gap for rocks that are herein called Bloomsburg. Interestingly, the Clinton was not used for rocks in southeastern New York (Fisher, 1960) that are part of the outcrop belt that extends into eastern Pennsylvania. However, the name is so ingrained in Pennsylvania literature (e.g., Swartz and Swartz, 1931; Wood and others, 1969) that the name is retained. As described above, the clinton Hember, in the area of this report, is a tongue of the clinton Formation of Swartz and Swartz (1931). The reference section for the Clinton liember is in the exposures along U.S. Interstate 80 in Delaware Water Gap where the member consists of alternating shaly siltstone and quartzite (fig. 13). 


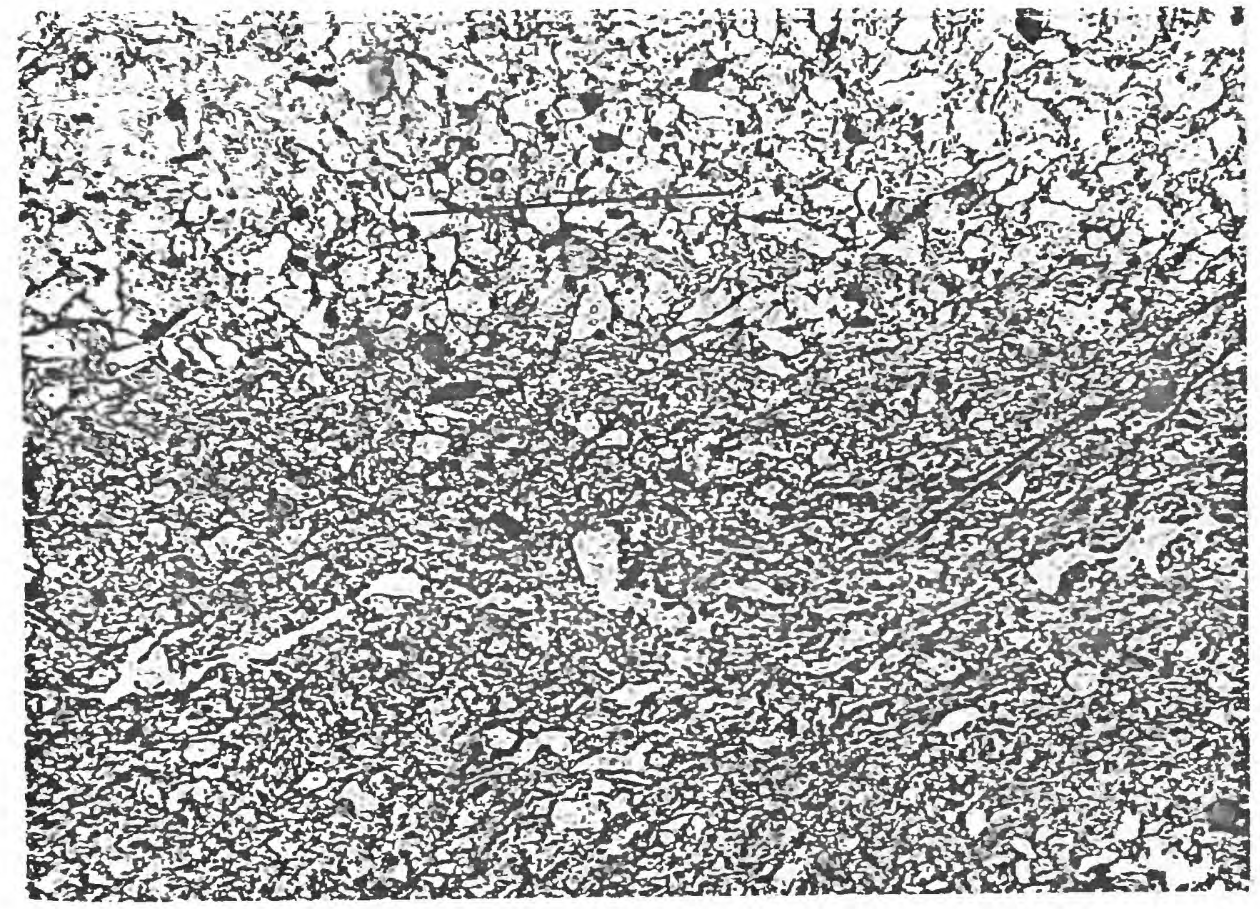

Figure 12. Photomicrograph (plane-polarized light, X 150) of siltstone, Minsi Member of the Shatrangunk Formation, Delaware Water Gap, Portland quadrangle, New Jersey. Top of unit 9 of measured section 1. Coarse siltstone lamina channeled into fine siltstone. Coarser grains are mostly quartz and lesser muscovite. Finer mat rix is composed of quarta, muscovite, and chlorite. Irregular cleavage $\left(\mathrm{S}_{1}\right)$ is at an angle of $50^{\circ}$ to bedding $\left(\mathrm{S}_{0}\right)$. 


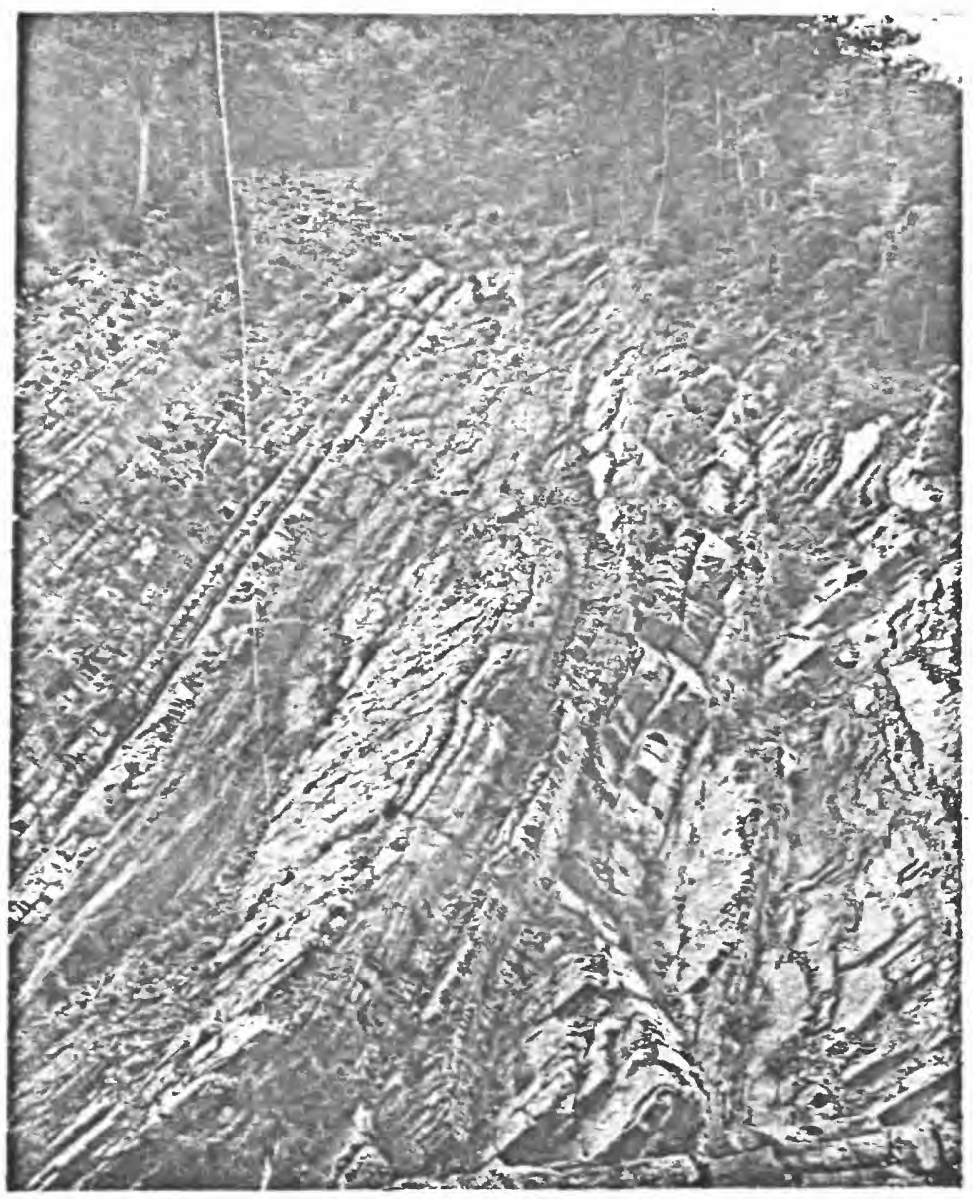

Figure 13. Reference section of the Clinton Hember of the Shawangunk Forration along U.S. Interstate 80, Delaware Water Gap. The unit consists predominantly of evenly bedded alternating shaly siltstone and quartzite. 
Stratigraphic details are given in measured section 1. The contact with the underlying Kirsi Nember is gradational.

The Clinton liember is 273 feet thick at Delaware Water Gap, and presumably thickens slightly restward in the Stroudsburg quadrangle as judged from regional relations (fig. 8). The quartzites are mediumlight gray to medium-dark gray and light-olive gray, fine to coarse grained, laminated ( 1 ig. I4) to planar bedded, rippled (fig. 15), and flaser-bedded (fig. 16). Convolutions occur locally (fig. 17). Many quartzites are limonitic, calcitic, and pyritic; some contain rare flakes of graphite. White-weathering, black phosphatic nodules (fig, 16, 18) are comnon in some beds. The phosphatic mineral is carbonate fluorapatite (determined by X-ray diffraction methods).

The quartzites appear to lack the feldspar that is cominon in the wherlying linsi lembcr. They are mostly protoquartzites, although close to orihoquartzite in mineral composition (fig. 19).

The quartzites are interbedded with medium-dark-gray to dark-gray, laminated, flaser-bedded, evenly to unevenly bedded, and burrowed (fig. 20) siltstone and shaly siltstone.

The Clinton Member generally forms steep slopes on BIue and Kittatinny Mountains.

Tamnany Kember

The Tammany inember of the Shawangunk Formation is named for lit. Tanzany overlooking Delaware Water Gap, Warron County, N. J., Portland quadrangle. It forms the crest of most of Kittatinny and Blue Hountains. The type section is in Delaware Water Gap (fig. 2I), where, along U.S. Interstate 80 , it is 816 feet thick, but it thickens to about 1,500 feet to the northwest in the gap, at the expense of the overlying 


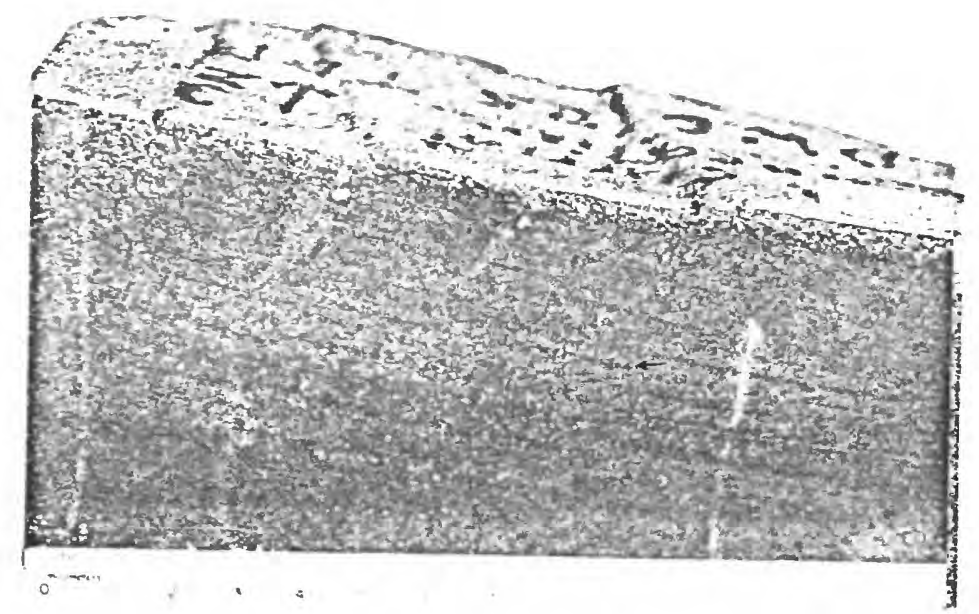

Figure $1_{4}$. Laminated, well-sorted, fine-grained calcitic sandstone (protoquartzite, perhaps approaching orthoquartzite), believed to be a beach or barrier-bar deposit (see section on environments of deposition). Primary current lineation (not apparent in photograph) is present on the upper bedding surface and parallels the dip of the laminae. Small rioges on bedỏing surface are not ripples but off sets of small soft-rock faults (arrow) that paralleled the ancient strand line. Clinton Member of the Shawangunk Formation, Delaware Water Gap, N. J. Unit 25 of measured section 1 . 


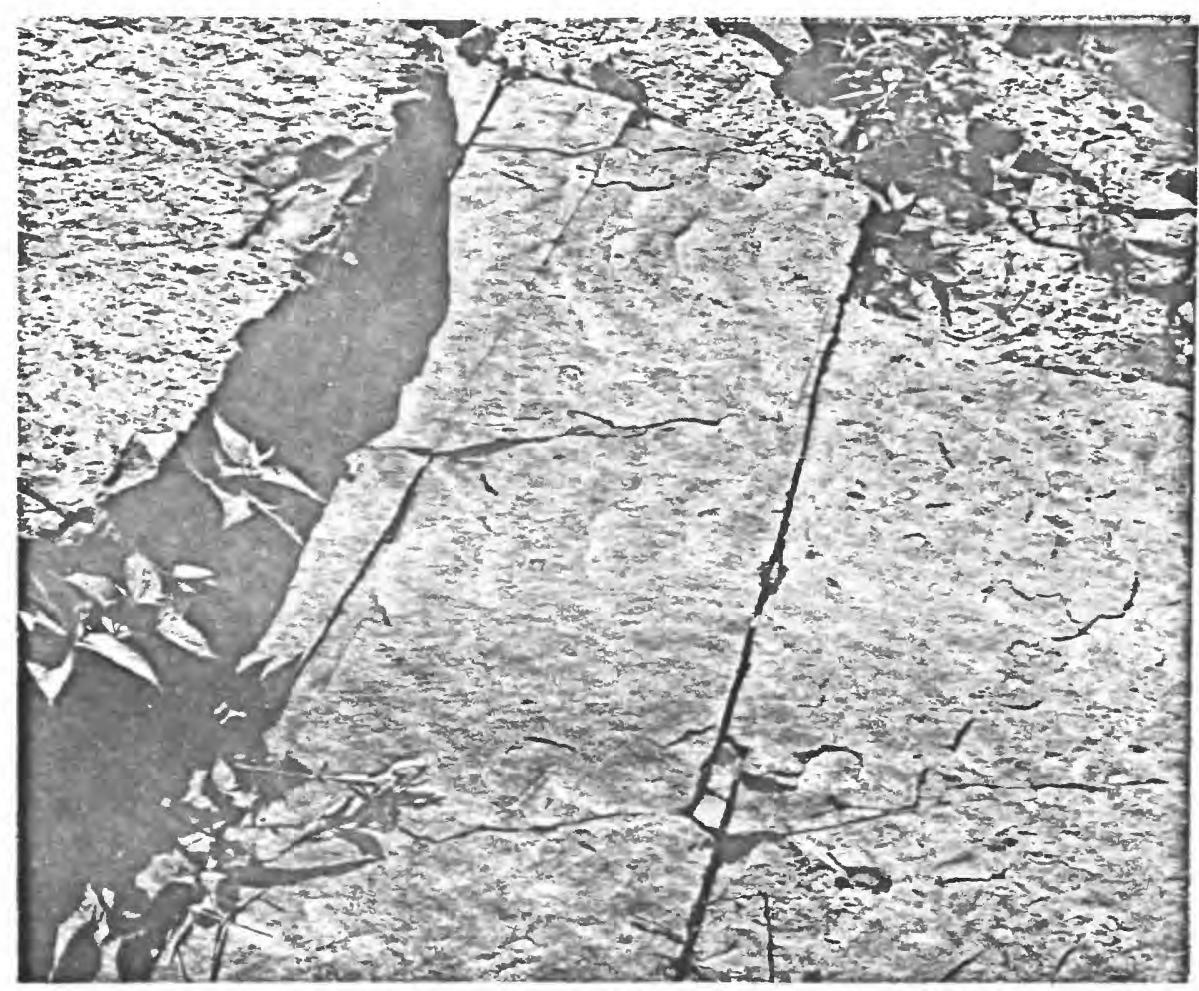

Figure 15. Asymmetric ripples in fine-grained sandstone. Ripples have wavelengths of about 4 inches and amplitudes of about $\frac{1}{2}$ inch. Clinton Member of the Shawangunk Formation, Delaware Water Gap, N. J. Unit 35 of measured section 1 . 


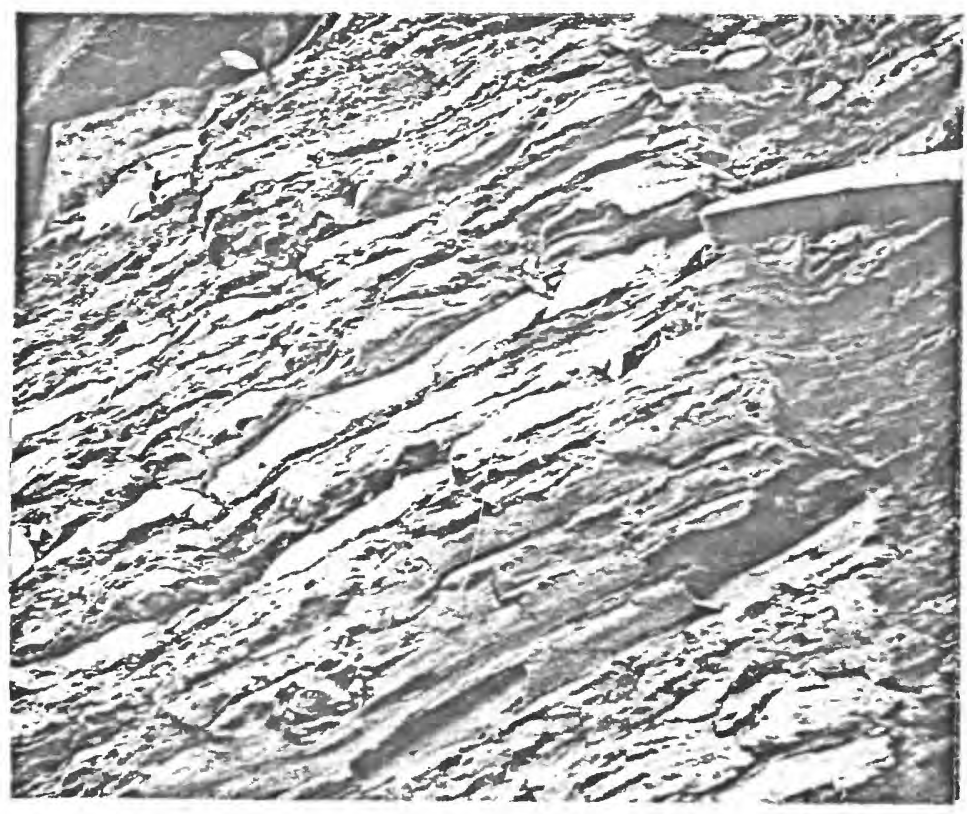

Figure 16. Flaser-bedcled (ripple lenses), fine-grained sandstone irregularly interbedded with burroved muddy siltstone. Hany of the sandstones have load-cast sole markings. Black phosphate nodules that weather white, as much as $1 \frac{1}{2}$ inches long, are scattered throughout. See figure 18 for photomicrograph of unit. Clinton liember of the Shawangunk Formation, Delaware Water Gap, N. J. Unit 46 of measured section 1 . 


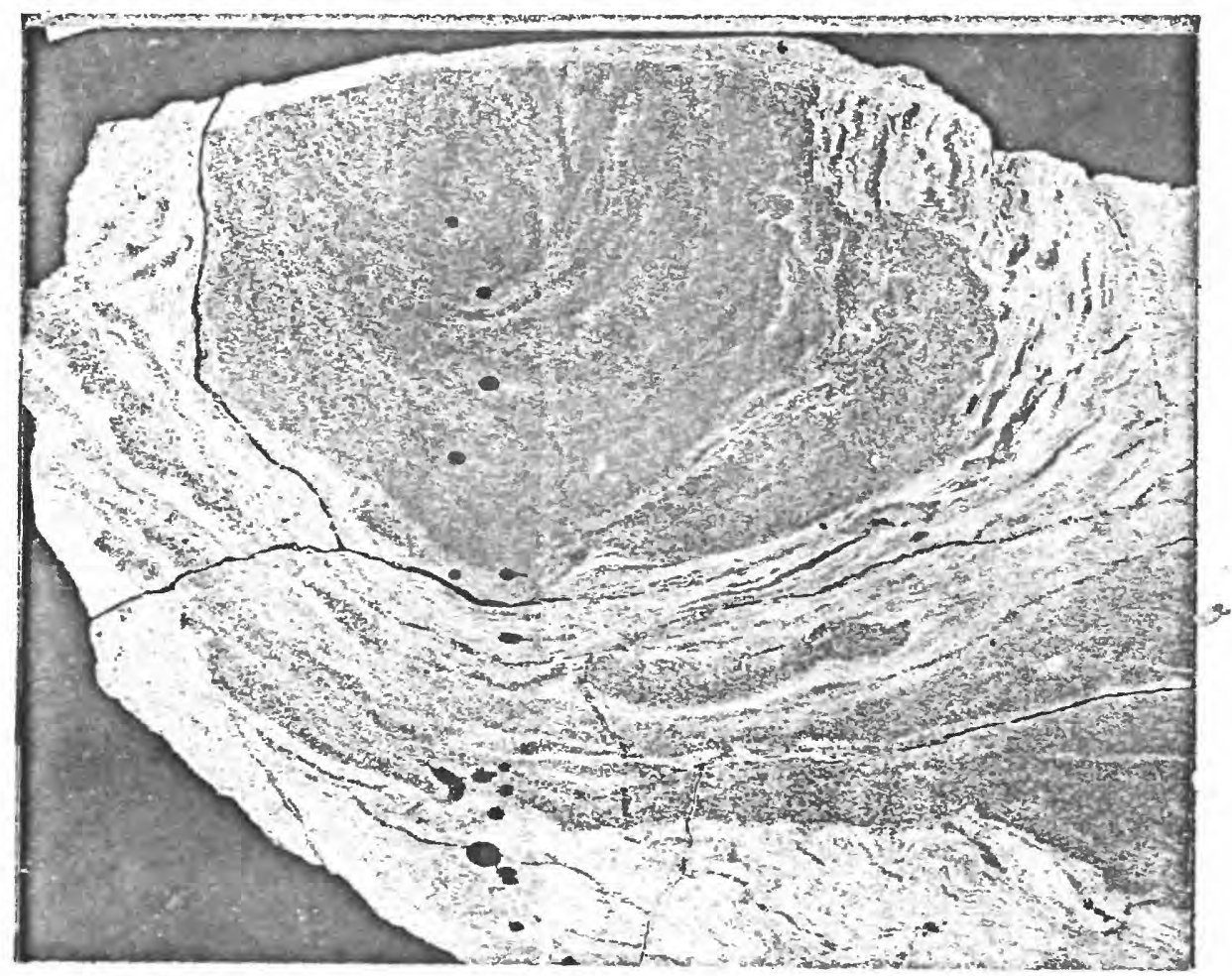

Figure 17. Convolutions (ball-and-pillow structure), due to soft-rock slumping, in very fine grained sandstone and siltstone. Note overturned and refolded flow fold at top. Negettive print of acetate peel. Clinton Member of the Shawangunk Formation, Delaware Water Gap, N.J. Unit 43 of measured section 1. 


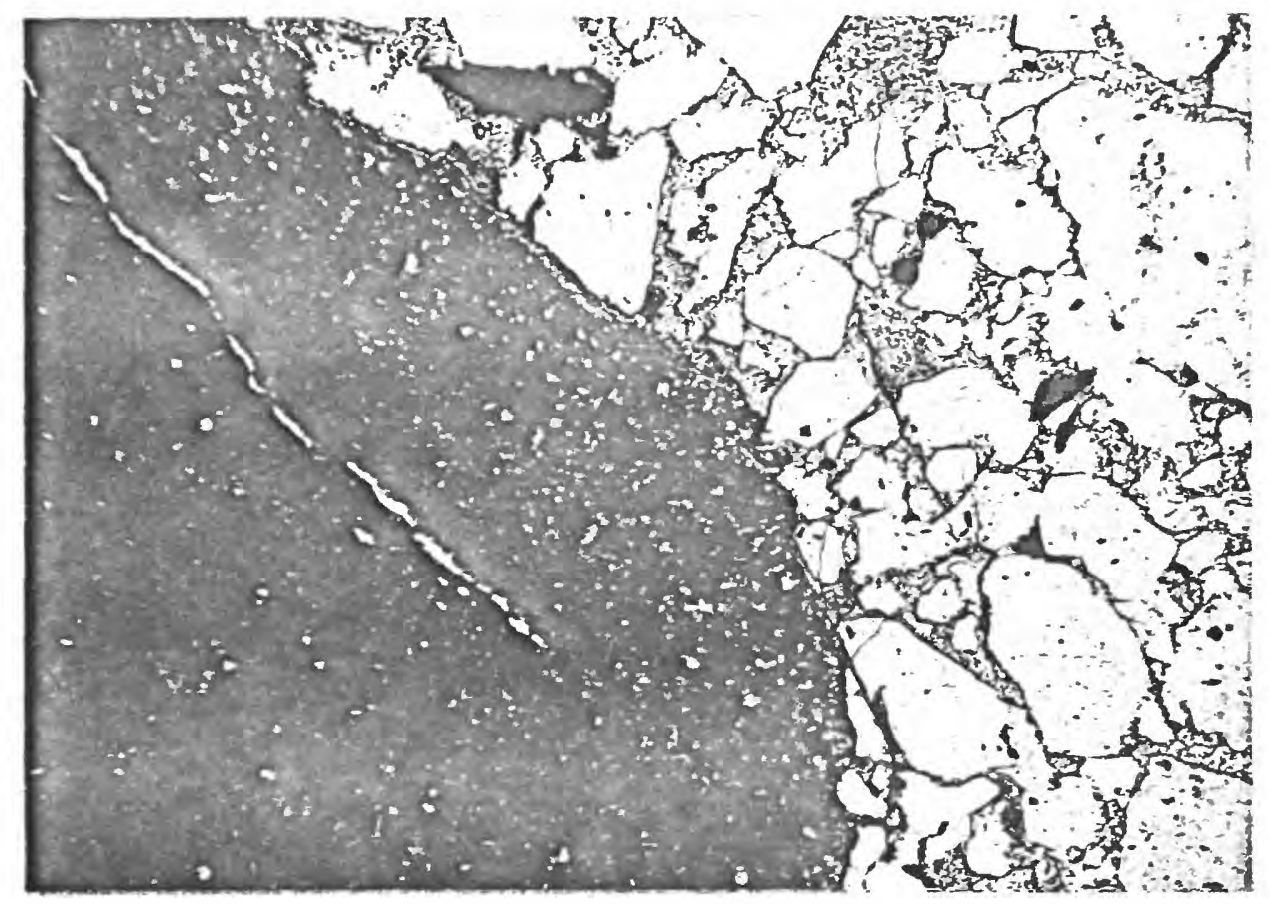

Figure 18. Photomicrograph (crossed polarizers, X 43) of phosphatic shale (large dark grain) in protocuartzite, Clinton Hember of the Shawangunk Formation, Delaware Water Gap. Unit 46 of measured section 1 . Figure 16 shows outcrop. 


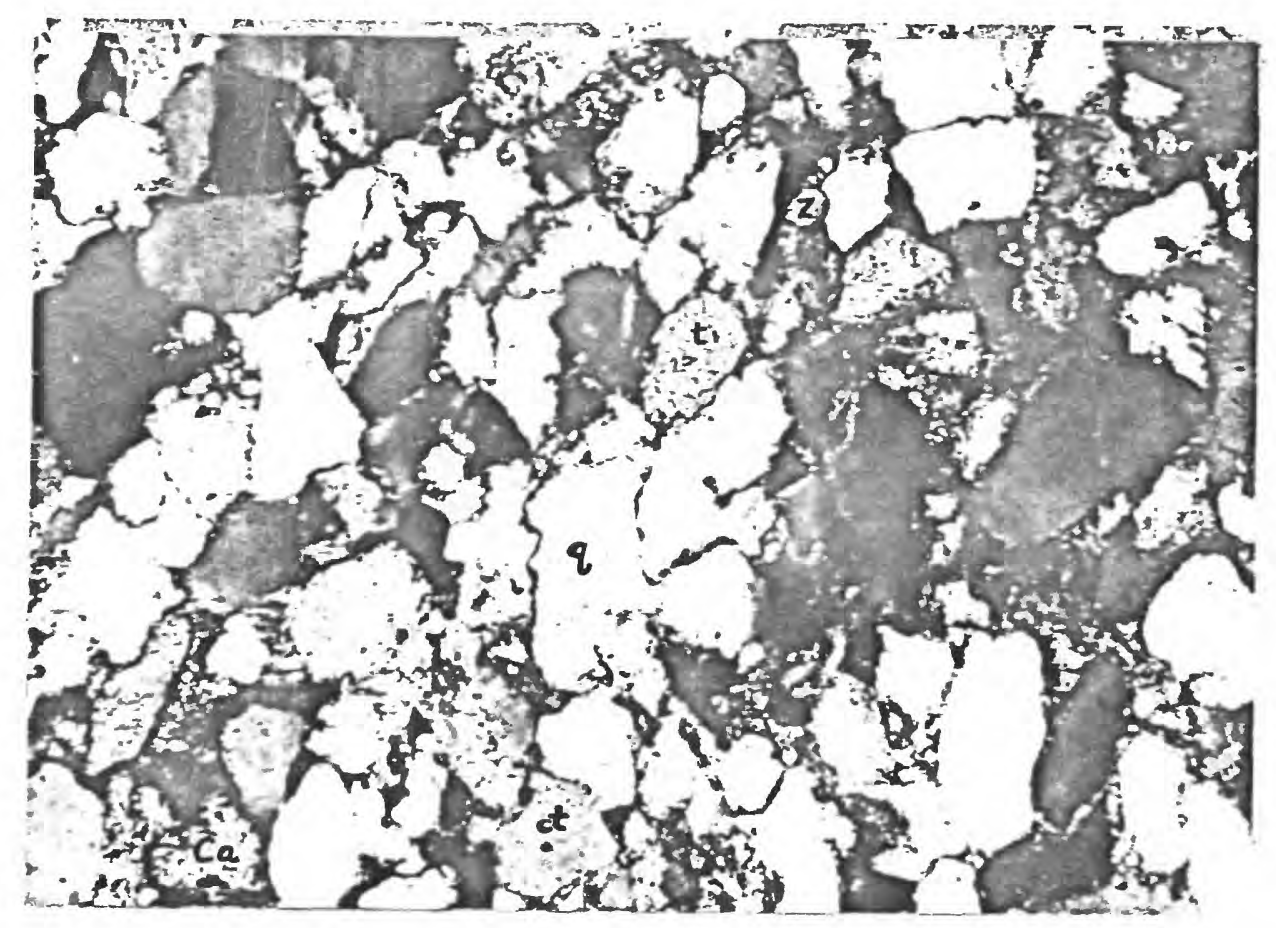

Figure 19. Photomicrograph (crossed polarizers, X110) of finegrained quartzite, Clinton Member of the Shawangunk Formation, Delaware Water Gap, Portland quadrangle, N.J. Unit 25 of measured section 1. Quartz (q) and minor chert ( 86 percent) are the dominant minerals in a muscovite and chlorite matrix. Some matrix is entirely recrystallized to chlorite (pennine). Note the straight to interlocking contacts between quartz grains. Limonite-stained carbonate (probably calcite) ( $\mathrm{Ca}$ ) forms a cement in some areas and makes up about 4 percent of the rock. Minor potash feldspar ( 1 percent) and rock fragments (shale, about 1 percent) were noted. Heavy minerals are not uncommon and include subrounded to rounded tourmaline $(t)$, zircon $(z)$, and rutile. The composition of the rock is on the borderline between that of a protoquartzite and orthoquarizite. Figure I4 is a photograph of the rock sarnple. 


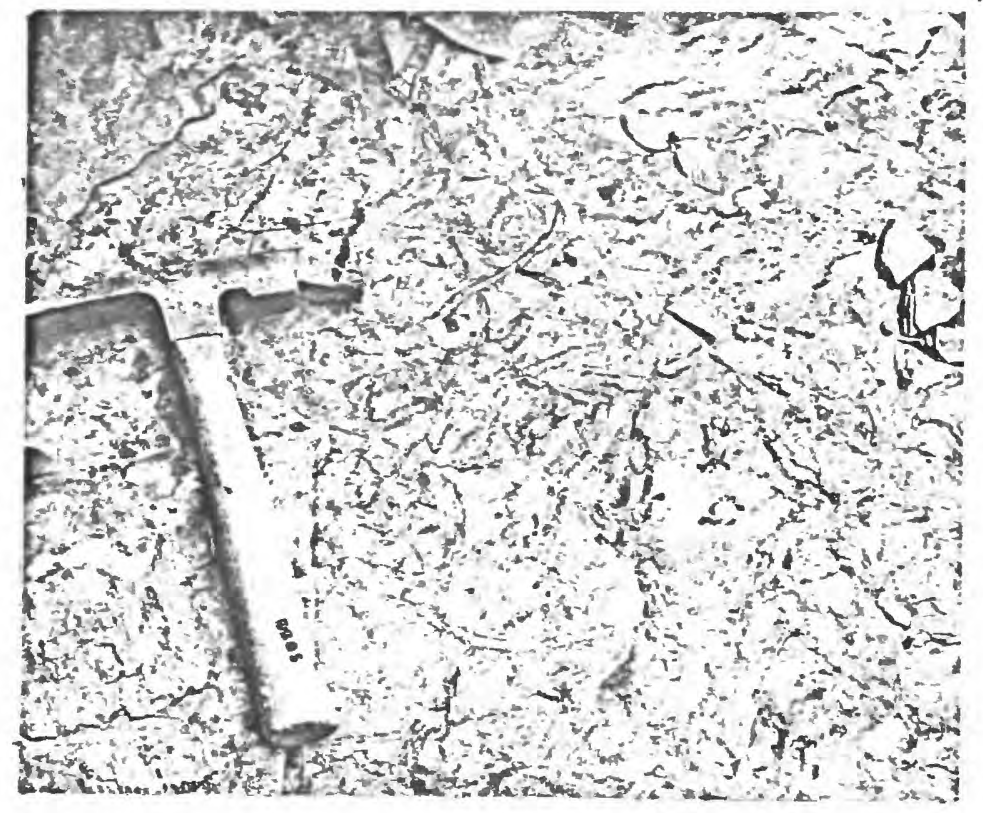

Figure 20. Feeding burrows on bedding plane of siltstone in Clinton Hember of the Shawangunk Formation. Delaware Water Gap, N.J. Vertical burrows, more than 1 foot deep, are al so common. Unit $3 I$ of measured section 1 . 


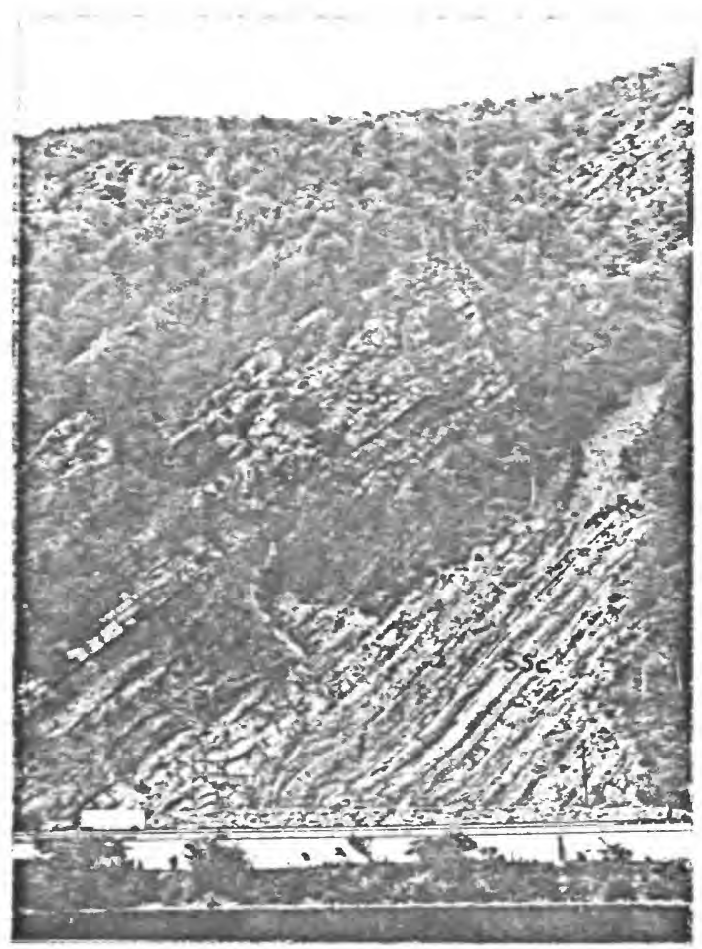

Bicure 21. Type section of Tammany Hember (Sst) of the Shawangunk Forastion overlying the Clinton Hember (Ssc) at Delaware Water Gap,
M. J. 
Bloonsburg Red Beds.

The sandstones of the Tamany Member are sjmilar to those of the Minsi Meinber, except that feldspar does not seem to be as abundant in the Tanmany ( $<1$ percent). The Tammany consists of mediurn-gray to mediur-dark-gray, fine-to very coarse grained, planar-bedded to crossbedded, limonitic, pyritic, evenly to unevenly bedded quartzite and about 2 percent dark-gray shaly siltstone. Flattened shale pebbles are common. Quartz pebbles are as much as 2 inches long. The quartzites are predominantly protoquartzites (fig. 22).

Unique dolomite beds occur near the top of the Tammany Nember about 400 feet south of the contact with the overlying Bloomsburg Red Beds and a few hundred feet north of the tollgate on U.S. Interstate 80 near the village of Delaware Water Gap, Pa. These beds are about 4 feet thick and consist of a medium-gray dolonite that weathers moderate brown and an upper greenish-gray dolomitic shale or shaly dolomite (fig. 23). The medium-gray dolomite is nearly pure ferroan dolomite (determined by $\mathrm{X}$-ray diffraction and staining techniques). Minor calcite, quartz, muscovite, and a $114 \AA$ mineral, probably chlorite, were noted on the $X$-ray trace. The rock reacts slightly with cold dilute hydrochloric acid. The greenish-gray dolomitic shale or shaly dolomite consists of ferroan dolomite with about equal amounts of muscovite, quartz, and chlorite. No calcite was noted and the rock does not react with dilute $\mathrm{HCl}$. Concretions of dolomite and calcite between $\frac{1}{2}$ and 3 inches in diameter, with concentric structure, are abundant. The dolomite beds are overlain and underlain by crossbedded and planar-bedded, predominantly medium grained, partly conglomeratic quartzites and siltstone. The lower bed contains irregular patches of rock similar to the upper bed. In thin 


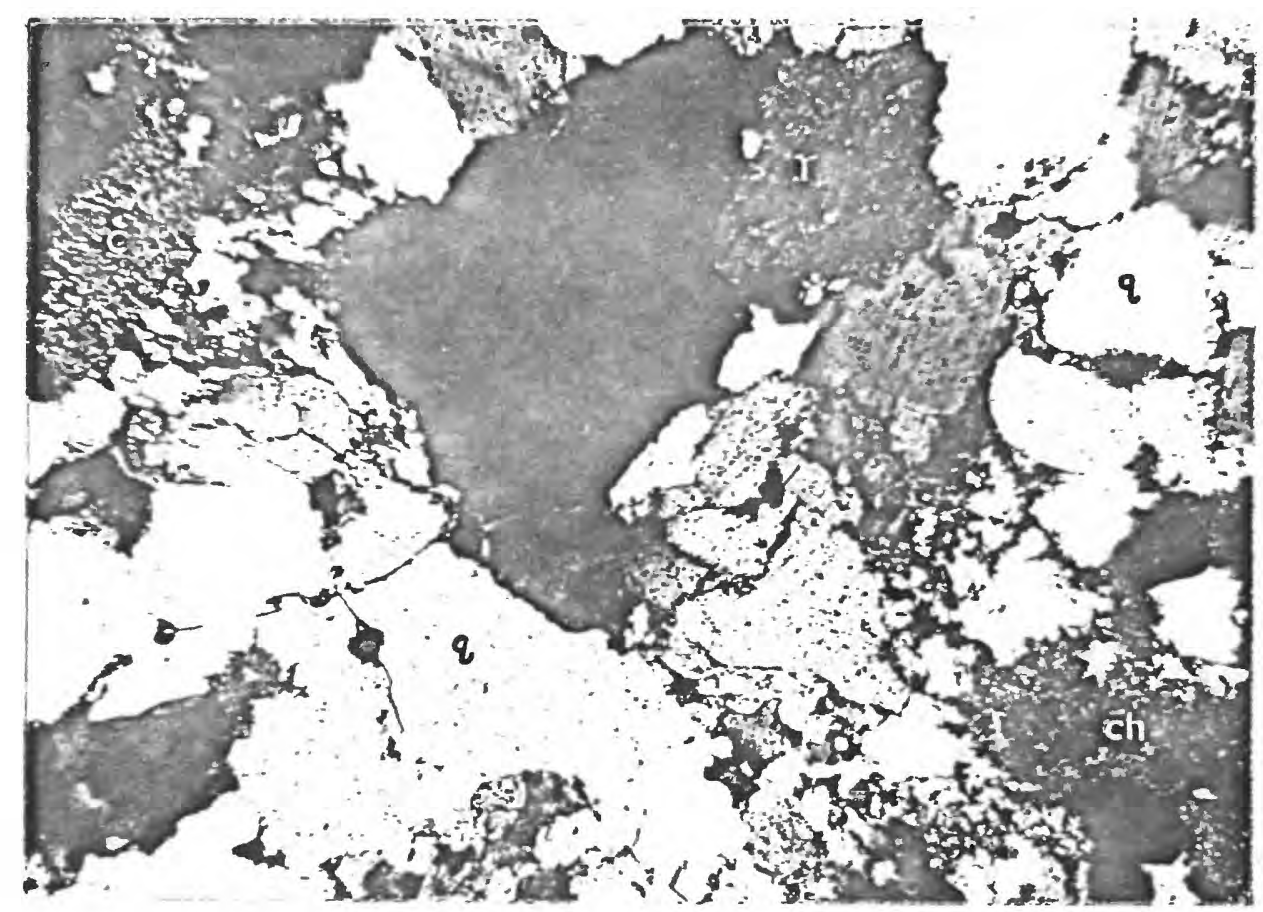

Figure 22. Photomicrograph (crossed polarizers, X 43) of conglomeratic coarse-qrained protoquartzite, Tammany Member of the Shawangunk Formation, Delaware Water Gap (unit 58 of measured section 1). Framework minerals are quarta ( $q, 80$ percent), chert (c, I percent), rock fragrents ( $r$, shale and siltstone, $I$ percent), and minor muscovite and zircon. The quart $z$ is rutilated and contains abundant racuoles and minor vermicular chlorite inclusions. 'lhe quartz grains are ancular to subrounded, simple to composite, and have straight to undulose extinction. Grain contacts are strajght to concave. The matrix (18 percent) is composed of fine quartz, muscovite, and chlorite. Some areas are recrystallized to spherulitic chlorite (ch). Note peripheral growth of mica on some quartz grajns. 


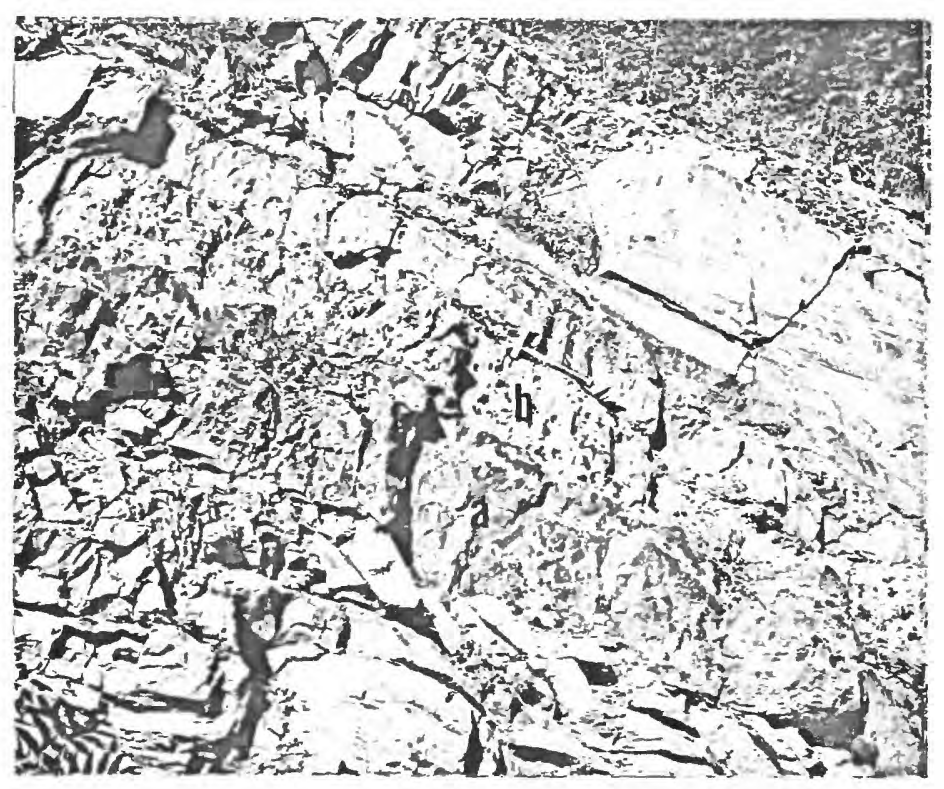

Figure 23. Medium-gray dolomite that weathers moderate brown (a, about 2 feet thick) overlain by greenish-gray dolomitic shale or aly dolomite with nodules of calcite and dolonite with concentric atructure (b, about 1.8 feet thick). Hammer is at contact with orerlying fine- to modiurn-grained feldspathic sandstone. Tammany Hember of the Shawangunk Formation, near tollgate on U.S. Interstate 80 , at village of Delaware. Water Gap, $\mathrm{Pa}$. 
section (fig. 24), the miediun-gray dolomite consists of a mosaic of slightly clouded dolomite grains averaging about $0.04 \mathrm{~mm}$ in diameter that replace the dolomitic shale or shaly dolomite. A thin rim of a clearer carbonate mineral (calcite?) and minor quariz locally separates the two rock types. The calcite(?) and quartz are alined parallel to a poorly developed rock cleavage and are found in the pressure-shadow areas surrounding the shaly rock. It is, the refore, believed that the calcite(?) and quartz formed during development of rock cleavage and not curing replacement by the medium-gray dolomite. The rock cleavage cuts both dolonite and shaly dolomite and postdates the original replacement. Ferroan dolomite nodules occur in scattered beds overlying and underlying this horizon, as well as in the overlying Bloomsburg Red Bods.

The lower boundary of the Tamany Member is transitional and is Plsced at the top of the last siltstone of the interbedded siltstonequartzite sequence of the underlying Clint on Member. The upper contact is placed at the base of the first red bed. This color contact is ux:ecal; irregular, transects bedding, and rises about 700 feet within - Msplzontal \&stance of less than 1 mile in Delaware Water Gap (see croses accsion $E_{-} E^{\prime}, \mathrm{pl}$. II and measured section 2).

The I1tholocle contrast between the Bloomsburg and Shawangunk is Litrotse Indstinct, so that lithologies could not be used conveniently fat a marrable boundary. The color change was used because it has been The accoptad anthod of separating the two formations (Willard, 1938, p. 12). asd bockusso it is the most satisfactory method when mapping float (the coetact is corered in most areas beyond Delaware Water Gap). Gray 


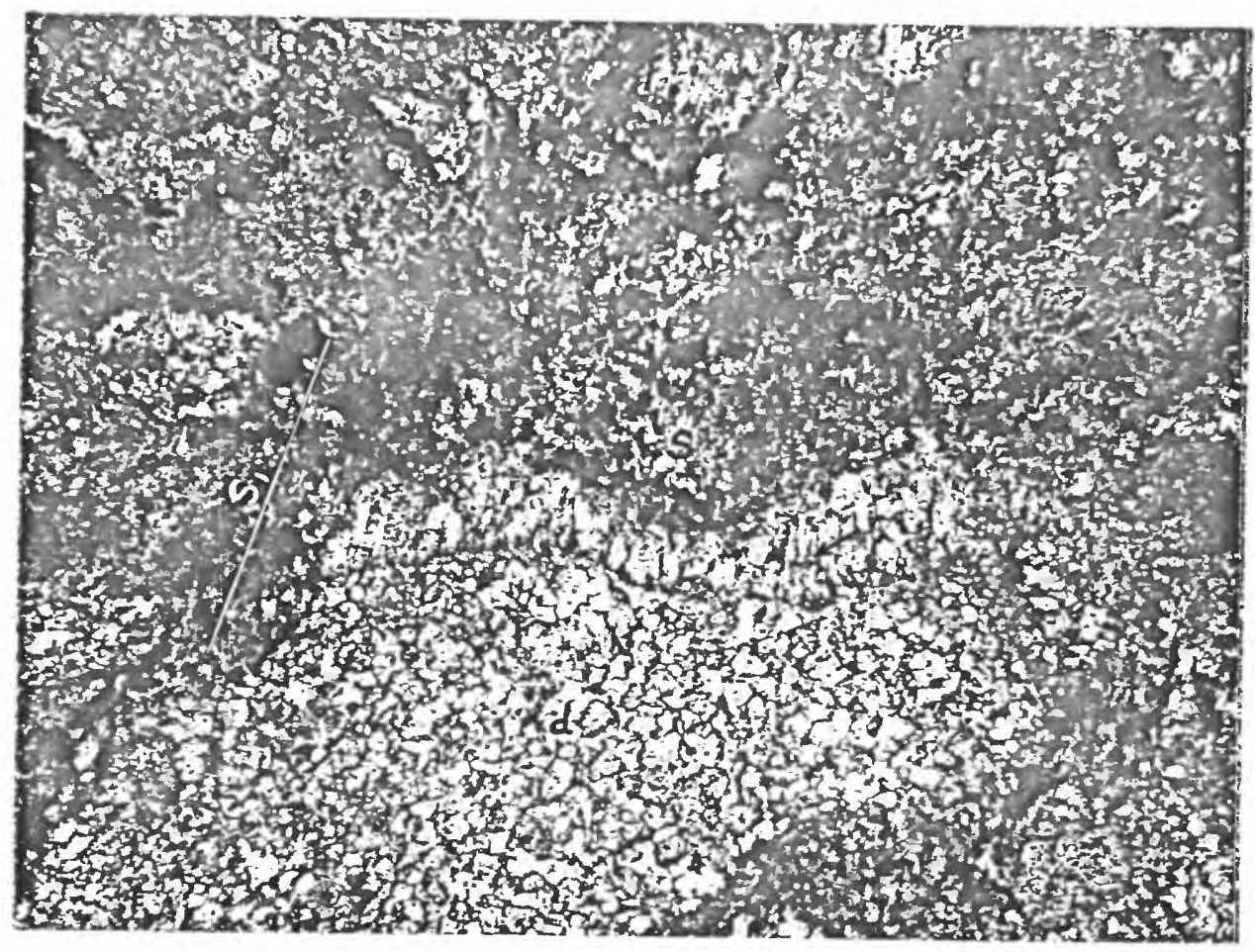

Figure 24. Photomicrograph (plane-polarized light, X 56) showing ferroan dolomite (d) replacing dolomitic shale or shaly dolomite (s). Rims of clear carbonate (calcite?) and minor quartz with comb structure (arrow), subparallel to cleavage $\left(S_{1}\right)$, are believed to have grown during cleavage development. Cleavage cuts both dolomite and dolomitic shale. Sample f'rom rock shown in figure 23. 
quartzites and siltstones in Dunnfield Creek, Portland quadrangle, about 0.5 mile northeast of Delaware River, were mapped as Bloomsburg because it was not possible to determine whether they are continuous with upper Taminany rocks. If no red beds underlie them, then they are part of the Tamany Member.

Age of the Shawangunk Formation

The Shawangunk Formation of eastern Pennsylvania has been regarded as Early to Middle Silurian in age (Swartz and others, 1942). This age assignment was based primarily on the occurrence of eurypterids and Arthrophycus and on regional stratigraphic considerations. The evidence appears not to have been unequivocal and needs re-eval uation. The base of the Shawangunk conceivably could be latest Ordovician in age.

In central Pennsulvania, the clastic rocks inmediately overlying the Martinsburg Formation are, in ascending order, the Bald Eagle Member of the Juniata Formation of Willard and Cleaves (1939), the Juniata Formation, and the Tuscarora Sandstone. No diagnostic fossils have been found in the Bald Eagle and Juniata, and their age is still uncertain (Willard, 1943, p. 1091; Swartz, 1942, p. 178), although they are generally believed to be Naysvillian and Richmondian in age (Twenhofel and others, 1954). East of the Susquehanna River, near Harrisburg, Pa., the Bald Eagle and Juniata pinch out, and at the Lehigh River the Shawangunk Formation, which is laterally continuous with the Tuscarora, rests directly on the Martinsburg Formation. For this reason, it was assumed that the base of the Shawangunk is Early Silurian in age. However, there is no reason to believe that parts of the basal shrwengunk are not correlative with rocks of the Juniata or Bald Eagle. Lack of 
diagnostic fossils in these rocks makes this suggestion a possibility. In southeastern New York, basal Shawangunk beds are believed to be Hidjlo Silurian in age, but the lack of key fossils nakes this correlation questionable (Fisher, 1960).

The Juniata-Tuscarora contact, which supposedly marks the OrdovicianSilurian boundary in central Pennsylvania, is complex and nay be time transgressive (Swartz, 1942, p. 186). The two formations are transitional, and the contact is drawn with difficulty (Folk, 1960, p. 5-6). It is, therefore, clear that the Juniata-Tuscarora boundary may not be a time line separating Ordovician and Silurian rocks. This point is clearly made by Thompson (1970a).

Further confusion regarding the Ordovician-Silurian boundary in eastern Pennsylvania can be traced to Willard and Cleaves (1939, p. 1185), who believed that a remnart of the Bald Eagle can be found at Lehigh Gap and east into Northampton County. If this were true, the basal clastics underlying the Blue Mountain in this area would be Naysvillian in age (Willard, 1943, p. 1118). The identification of the Bald Eagle at Lehigh Gap is suspect. Epstein and Epstein (1967, 1969) placed the basal conglomerates at Lehigh Gap in the Shawangunk. There Is no compelling reason to believe that the conglomerates are distinct from overlying beds, and the disconformity that Willard and Cleaves (1939) postulate between what they believe to be Bald Eagle and the Shawangunk, because of the absence of the intervening Juniata, does not exist.

The age of these rocks is further clouded by the previously held 8upposition that unconformities mark systemic boundaries. Thus, 
Willard and Cleaves (1939, p. 1765) maintained that the Juniata is either Silurian or Ordovician depending on acceptance of one of two proposed hiatuses in eastern Pennsylvania as the Ordovician-Silurian boundary.

Bald Eagle, Juniata, Tuscarora, and Shawangunk rocks in central and eastem Pennsylvania are shallow marine and fluvial clastics derived from uplifted highlands to the southeast as the result of the Taconic orogeny (for example, Swartz, 1948; Thomson, 1957; Folk, 1960; Yeakel, 1962; Horowi.tz, 1966; Epstein and Epstein, 1967, 1969; this report). Their interpreted environnent of deposition is in shaxp contrast with the deep-water origin suggested for most of the Martinsburg (ICBride, 1962). Because the Taconic orogeny may have been more or less synchronous in central and eastem Pennsylvania, the detritus that makes up the Junjata and $B_{a l . d}$ Eagle in central Pennsylvania could be partly of the some age as the Shawang unk in eastem Pennsylvania, even though "layer-cake" interpretations suggest that the Juniata and Bald Eagle are older.

The Shawangunk Formation is sparsely fossiliferous. No fossils were found in the lower 300 feet which consist predominantly of quartite and conglomerate between Lehigh and Delaware Rivers. In the overlying interbedded shales, siltstones, and sandstones (Clinton Formation of Swartz and Swartz, 1931; quartzite-argillite unit of Epstein and Epstein, 1967, 1969; Clinton Nember of this report), the only reported fossils are rare occurrences of Arthrophycus (Schuchert, 1916), eurypterids (Clarke and Ruedemann, 191.2), Dipleurozoa (Johnson and Fox, 1968), and Lingula (Epstein and Epstein, 1969). Lingula, a Iong-ranging facies 
fossil, and dipleurozoans, very rare as fossils, cannot be used for correlation:

Arthrophycus alleghaniense, in the Shawangunk-Tuscarora of Pennsylvania, New Jersey, and New York, was believed to be a guide fossil for the Lower Silurian (Fedinan) by Schuchert (1916), Willard (1928), and Swartz and Swartz (1930). Arthrophycus has been regarded as a fossil worm or plant remains (Becker and Donn, 1952) but is now generally recognized as a feeding burrow (Hăntzschel, 1962). According to Seilacher (1955), these ichnofossils generally have no age significance but are environmentally controlled. Amsden (1955), Pelletier (1958), and Yeakel (1962) shoired that Arthrophycus was st rongly facies contralled, apparently limited in occurrence to transitional fluvial and marine environments. It is obvious, therefore, that Arthrophycus is a facies fossil and cannot be used to date the Shawangunk.

Eurypterid remains have been found in the Shawangunk Formation at Otisville, N. Y., and Delaware Water Gap, Pa., and in the Tuscarora Sandstone at Swatara Gap, Pa. (Clarke and Ruederiann, 1912; Swartz and. Swartz, 1930, 1931). These fossils were considered to be Early Silurian in age. Swartz and Swartz (1930, p. 473), however, sounded a note of caution, "It would seem inevitable to conclude that the Shawangunk is early Silurian unless the eurypterids are without significance for correlation." Grabau (1913) gave arguments for the fact that eurypterids were river-dwelling ortanisms, had wide ranges, and do not form "exact horizon markers" (p. 526). Clarke and Ruedemann (1912) were likewise a bit cautious, indicating that the identifications at Delaware Water Gap were tentative because (1) the eurypterids were altered and fragmented, (2) the evolution of eurypterids may have been slow and the complete 
ranges of species unknom, and (3) eurypterids are apparently facles controlied. Both Amsden (1955) and Stormer (1955) emphasize the scarcity and environmental control of eurypterids. Apparently, eurypterids are confined to brackish and fresh waters, which agrees with the environmental interpretation of the Shawangunk as a fluvialtransitional marine sequence (Epstein and Epstein, 1969; this report).

Thus, the eurypterids in the Shawangunk Formation and Tuscarora Sandstone, as well as Arthrophycus, cannot be used for precise age determination because of facies control and uncertainty of species ranges. It is interesting, in this regard, that Willard (1928, p. 257) cormpared the Shawangunk eurypterids with those found in the Upper Silurian Pittsford Shale and Upper Ordovician (Edenian) Frankfort Shale of New York. He found the closest faunal similarity with the Frankfort and concluded that the Shawangunk must be Early Silurian in age because "the presence of Arthrophycus in the Shawangunk points to its being Lower Silurian, since that organism is conceded to be of that age." In summary, the evidence used to date the Shawangunk Formation of eastern Pennsylvania has been based on insecure stratigraphic evidence and fossils that are strongly environmentally controlled and whose ranges are poorly known due to rare occurrences and facies control. The evidence needs re-evaluation. It is conceivable that the Shawangunk is Late Ordovician in age as well as Early Silurian. Perhaps Intensive investigations of the phytoplankton assemblages, as was done by cramer (1969) for the Rose Hill and Tuscarora Formations of central Pennsylvania, can be used to accurately date the se clastic rocks. 
The name Bloomsburg was first used by White (1883) for red beds at Bloomsburg, Pa. In eastern Pennsylvania, he (1882) called the same interval the Clinton red shale, whereas Rogers (1858) used the term Surgent for these rocks. The name High Falls, defined by Hartnagel (1905), has been used in New Jersey at the Delaware Water Gap (Stose, 1922). However, the Bloomsburg has priority and is, therefore, used in the Stroudsburg and Portland quadrangles. Regjonal relations of the Bloomsburg are given by Swartz and Swartz (1931) and details in easternmost Pennsylvania were described by Epstein and Epstein (1969).

The base of the Bloomsburg Red Beds in the area under study is at the base of the lowest red bed in the section. The top of the Bloomsburg is not exposed but is seen in cores drilled by the U.S. Army Corps of Engineers in the Delaware River, in the Bushkill quadrangle. This contact, with the Poxono Island Formation, is transitional and is placed where the ratio of red beds to nonred beds is 50:50. So defined, the Bloomsburg is between 800 and 1,500 feet thick in the Delaware Water Gap area (see discussion of Shawangunk-Bloomsburg contact under the Tarmany Member of the Bloomsburg Formation). This thickness is much less than previously reported: Chance (1882), 1,685+ feet; Grabau (1913), more than 2,300 feet; Swartz and Swartz (1931), 1,264 feet; Willard and Stevenson (1950), 2,300 feet. Much of the variation in reported thickness at Delaware Water Gap can be attributed to complex folding and the rapid color changes. Many of the beds included by Swartz and Swartz (1931, p. 648) in the upper part of the Bloomsburg are part of the Shawangunk Formation as herein defined. Similarly, the nonred sandterrs at Delaware Water Gap village were thought to overlie the Bloomsburg 
and to be part of the PoxoroIsland Fornation by Johnson and others (1933) and Willard (1938). Actually, these rocks belong to the Shawangunk Fornation brought up in an anticline.

-The Blocmsburg consists of sandstone, siltstone, and silty shale (measured section 2). The sandstones are quartzitic, limonitic, hematitic, crossbedded to planar-bedded, very fine to coarse grained, and soma are congloneratic. Angular to rounded quartz and jasper pebbles are as much as 0.5 inch long. Red shale clasts, similar in appearance to interbedded shales, are common. Beds are as much as 10 feet thick. The shale and siltstone are pale red to grayish-red purple, grayish green, pale green, greenish gray, and dark gray. Mud cracks, small-scale ripples, cut-and-fill structure, and ferroan dolomite concretions are common. The beds are generally thin or laminated, bedding is absent in many of the silty shales and shaly siltstones because it was destroyed by burrowing animals while the sediment was still soft. Fish have been found locally (Beerbower and Hait, 1959), as at the Iocality 1,000 feet north of the tollgate on U.S. Interstate 80 , near the village of Delaware Water Gap, Pa. Fish scales, as much as 0.5 inch long, are common in the bioturbated grayish-red shaly siltstone that is interbedded with Iminated grayish-green siltstone and minor medium-Eray fine-grained sandst one. Color boundaries between these rocks are very irregular. Green reduction spots around pyrite in the red beds are common at this locality and elsewhere. Many of the rock units in the Bloomsburg occur in upwards-fining cycles (fig. 25). These are discussed further in the section on environments of deposition. Mineralogically and texturally, the sandstone and siltstone in the Bloomsburg are Imuature. They probably range from lithic and feldspathic 
Figure 25. Upwart-fining cycles in the Bloomsburg Red Beds, 0.5 mile northwest of Dunnfield, N. J., Delaware Water Gap. The upper photograph shows the cycles, consisting of medium-grained crossbedded to planar-bedded sandstone resting sharply on the underlying unit and grading up into thin-beaded, laminated, and ripple-laminated sandy siltstone and fine-grained sandstone winich in turn grade up into laminated and bioturbated sandy and shaly siltstone that is partly mudcracked and contains dark-Jellonish-orange ferroan dolomite concretions averaging 1-2 inches in length. Three complete cyles and the top of a fourth are shown. Note southeast-dipping cleavage (to right). Photograph belorr shows details of the upper part of one cycle, with finely bedded to laminated siltstone and fine-grained sandstone grading up into mud-cracked sandy and shaly siltstone with dolomite concretions. Ripple lensing is common. Burrows are more abundant upward and in the uppermost beds bedding is nearly destroyed by bioturbation. 


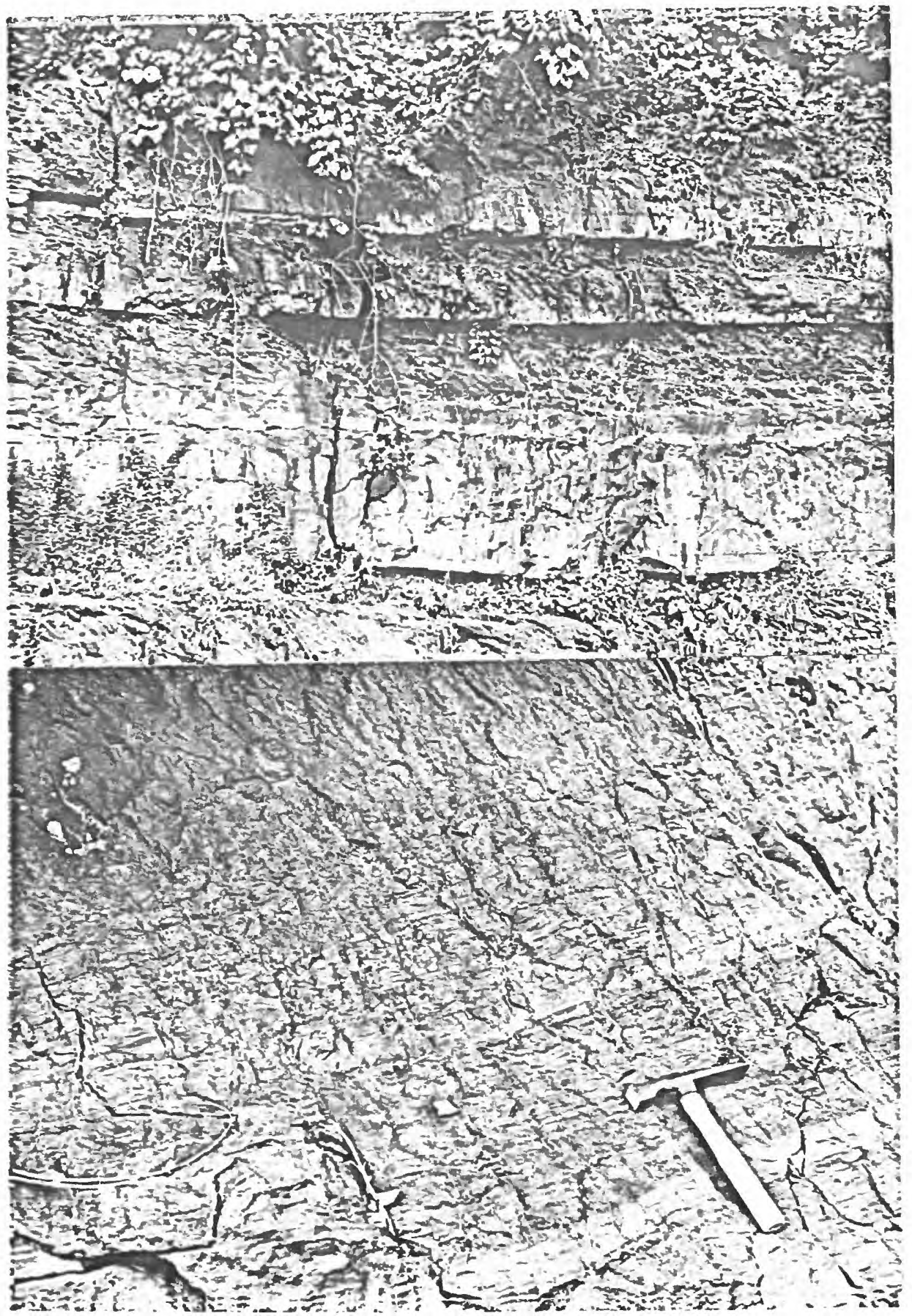


graywackes to subgraymackes. A thin section of a medium-grained lithic 55 graywacke, from Lehigh Gap, similar to rocks in the Delaware Water Gap area, shows a matrix of hematite (probably mostly an alteration product of iron-rich chlorite) and muscovite that constitutes 25 percent of the rock. Plagioclase is common, but more abundant rock fragments (slate, phyllite, schist, myrmekite?) comprise 6 percent of the rock. Of the 65 percent quartz, 15 percent is composite, sutured, and stretched, presumably indicating a metaquartzite source. Figure 26 shows a hematitic siltstone to feldspathic graywacke in Delaware Water Gap.

\section{Poxono Island Formation}

The Poxono Island Formation (misspelled in Wilmarth, 1957, p. 1724, as Poxino Island) is not exposed in the Stroudsburg quadrangle but presumably lies within a few tens of feet of the surface along the south slope of Godfrey Ridge at several localities. It was named the Poxono Island Shale by White (1882) for at least 200 feet of buff, green, and variegated, nonfossiliferous limy shales exposed on the north bank of the Delaware River near Poxono Island in the Bushkill $7 \frac{1}{2}$-minute quadrangle. These beds formed the base of Rogers' (1858) Scalent Formation which included all rocks up to and including the basal coevmans of this report.

White (1882, p. 240) reported 5 feet of the shale exposed in the Croasdale quarry at the east end of Godfrey Ridge in the Stroudsburg quadrangle. These rocks are presently concealed. Johnson and others (1933, p. 27) and Villard (1938, p. 10) believed that the Poxono Island crops out in the village of Delaware Water Gap. However, as previously mentioned, the gray and green shales and sandstones at Delaware Water 


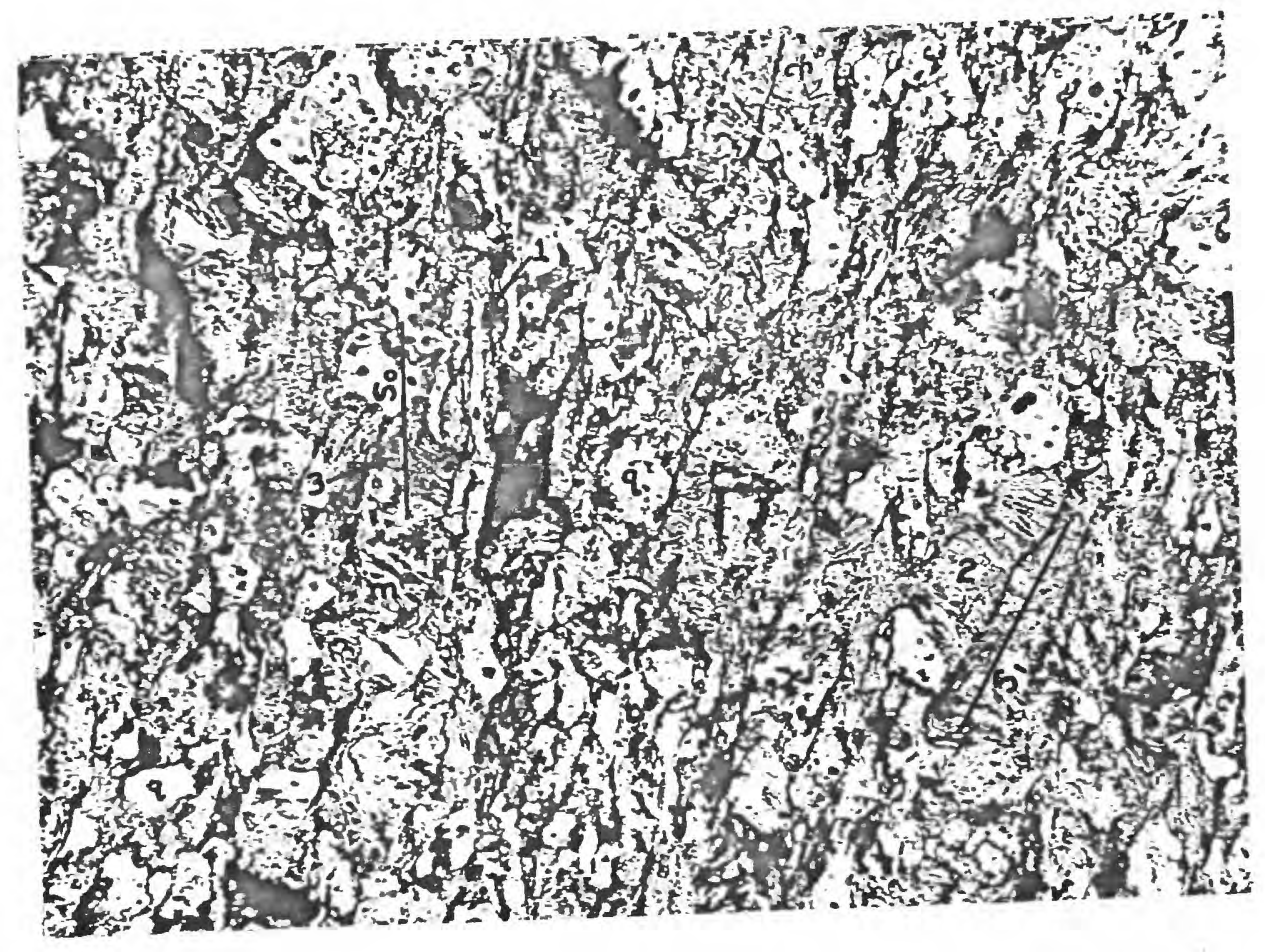

Figure 26. Photomicrograph (plane-polarized light, X 105) of hematitic coarse siltstone to very fine grained feldspathic graywacke, Blocmsburg Red Beds, 0.5 mile northwest of Dunnfield, N.J., Delaware Water Gap. Rock consists of quartz (q), muscovite (m), and chlorite (ch) in a finer matrix of the same minerals and hematite. The chlorite is pleochroic from light green to colorless and presumably is ironrich. Some intergrown chlorite and muscovite grains, which are presumably detrital, are elongated and have mineral cleavage parallel to bedding, $S_{0}$ (at 1). Others (at 2) are believed to have recrystallized because they lie parallel to and have mineral cleavage at right angles to rock cleavage $\left(\mathrm{S}_{1}\right)$. Some grains of muscovite (at 3 ) are dragged into rock cleavage as shown by sigmoidal mineral cleavage. The rock cleavage is defined by the parallel alignment of micaceous minerals that are more apparent under crossed polarizers. 
Gap village are part of the Shawangunk Formation brought up in the Cherry Valley anticline.

Exposures of the Poxono Island Formation occur along the north and west slopes of Cherry Valley 0.5 mile northeast and east of Bossardsville in the Saylorsburg quadrangle. The formation consists of Ereenish-gray calcareous and dolmitic shale, very finely crystalline light-greenishgray limy dolomite that characteristically weathers pale-yellowish orange and gravish orange, lesser amounts of fino-to medium-grained light-to dark-gray limestone resembling the limestone of the overlying Bossardville (White's Poxono Island Limestone? (1882, p. 146-147)), greenish-gray fine-grained sandstone, and moderate-grayish-red sandy shale. Most of the rock is laminated, probably few individual beds are more than I foot thick. Many beds are mudcracked. The probable thickness of the Poxono Island Formation, based on Iimited exposures and the outcrop width in the Bossardsville area, is estimated to be about 700 feet. The upper contact was seen only in the quarry south of Bossardsville and was placed at the top of the uppermost yellowishorange-weathering dolomitic bed in the section (Epstein and others, 1967, p. 71). So defined, the Poxono Island cont ains some limestone typical of the overlying Bossardville above. Moderate-grayishmed sandy shales were seen near the middle of the Poxono Island and probably increase in abundance downward. The boundary with the underlying Bloomsburg Red Beds is concealed but is probably transitional. 


\section{BOSSARUVIILE, LIRESTONE ${ }^{1}$}

The type locality of the Bossardville Limestone is at Bossardrille, $\mathrm{Pa}_{\bullet}$, in Cherry Valley, I mile west of the Stroudsburg quedrangle, where the limestone is extensively quarried. The Bossaruville was named by White (1882), who did not designate a type section, but who described $(p .240)$ the limestone at the north Croasdale quarry at the east end of Godfrey Ridge in the Stroudsburg quadrangle ( 0.5 mile southwest of Minisink Hills, $\mathrm{Pa}$.$) . The rocks in$ the quarry could serve as the type section. At this locality, White reported a basal. 25-foot unit consisting of bluish-gray, laminated, inpure limestone; a middle ("quarry") portion of 65 feet of dark, almost black, massive limestone; and an upper 20 feet of siliceous shaly beds overlain by 12 feet of greenish limy shales. The limy shales were not seen by Swartz and Swartz (1947, p. 1183).

In the nortinwest corner of the Croasdale quarry, not easily accessible, there is perhaps $/ 2$ to 13 feet of medium-gray to dark-gray dolomite that weathers yellowish gray to grayish orange. It is probably White's "greenish limy shales." It is herein placed in the Bossardville, but regional studies in progress suggest that it may be the Rosendale Waterlime of New York. Swartz and Swartz (1941, p. 1164) measured an incomplete thickness of 91 feet at the north Croasdale quarry consisting of an upper 19.5 feet of thin-bedded blue limestone with calcareous shalo at the base; 51.5 feet of massive, dark-blue, laminat ed limestone

1 In previous geologic literature the name has been spelled Bossardsville and Bossardville. The spelling used herein conforms to the Code of the American Commission on Stratigraphic Nomenclature (1961, p. 652, Art. 12, a). White (1032) originally spelled the name vithout the last $\underline{s}$. 
("quarry rock"); and 20 feet of basal blue-gray, shaly limestone with crinkly.stratification and mud cracks, partly concealed. Since the two quarries near the Croasdale Manor house are largely overgrown and covered at the bottom by loose blocks, the section was not measured. The base of the Bossardville is not exposed in the report area.

Regional relations and faunal lists of the Bossardville Limestone, as well as overlying Late Silurian and Early Devonian rocks, are given by Swartz and Swartz (1941). Epstein and others (1967) discussed the stratigraphic detajis of the rocks between easternmost Pennsylvania and southeastern New York.

In the Stroudsburg quadrangle, the Bossardville Limestone is exposed only at the east end of Godfrey Ridge in and near the two abandoned Croasdale quarries. The thickness of the Bossardville is about 100 feet. It is medium-gray to dark-gray, light-gray to grayish-orangeweathering, fine-grained to sublithographic, laminated to fine-bedded (figs. 27, 28), slightly argillaceous, sandy, and dolomitic limestone. Scattered pyrite is common. Light-olive-gray calcareous shale and siltstone occur as less abundant laminae. In thin section, the laminae appear as concentrations of quartz and rare plagioclase feldspar and muscovite in a matrix of micrite and lesser sparry calcite (fig. 29). The quartz is etched and partly replaced by the calcite. Many of the calcite larainations are less than $0.04 \mathrm{~mm}$ thick and may be of organosedimentary (algal) origin.

Many laminations are replete with leperditiid ostracodes (fig. 29). Many laminae and thin beds grade upwards from coarse sandy lime stones to finer calcitic shales or limestones. Many of these fining upward sequences have scoured bases (fig. 28). 


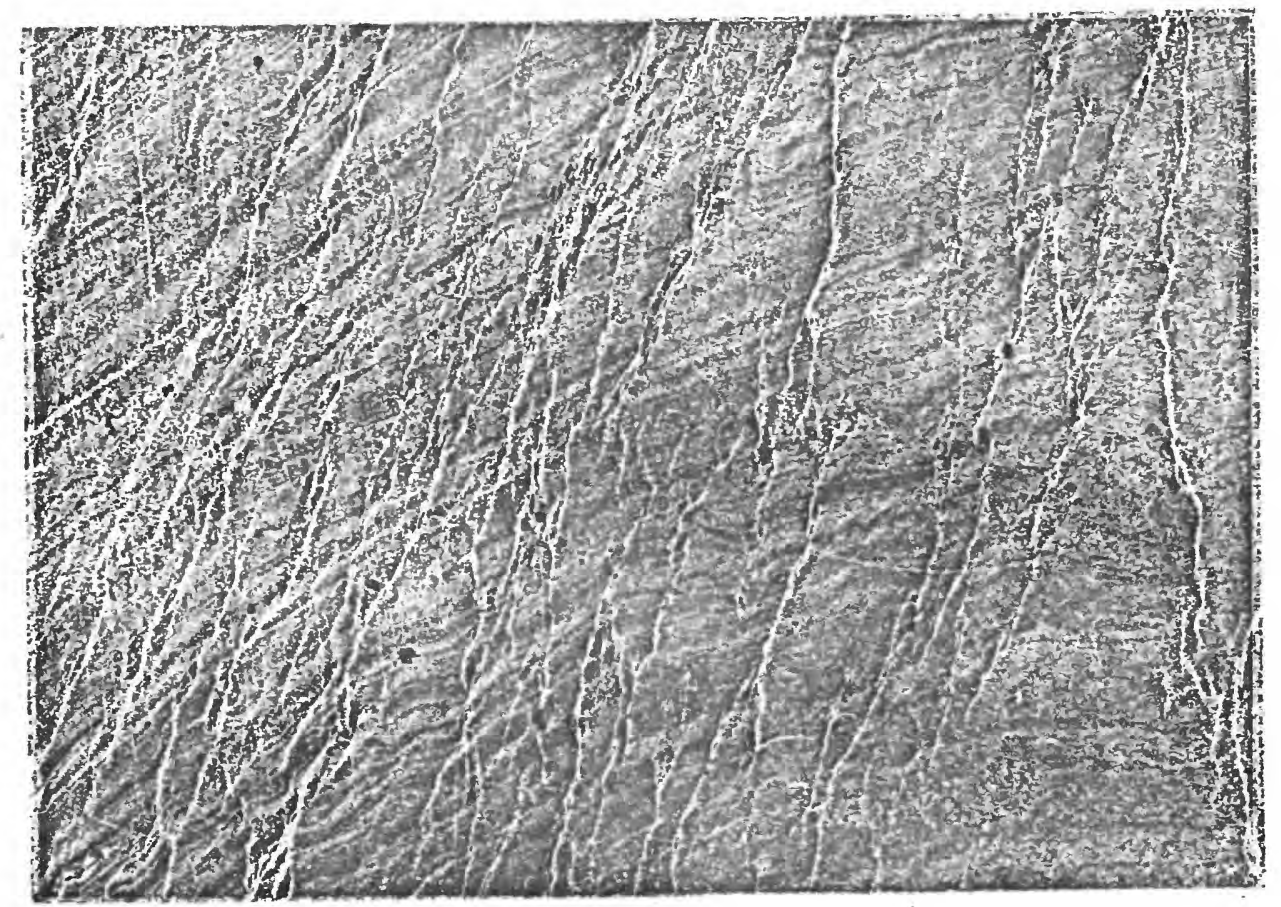

Figure 27. Iaminated micrite (light) and calcareous shale (dark) in mud-crack column, Bossardville Lirlestone, abandoned norith Croasdale quarry, about 0.5 mile southwest of linisink Hills, Pa. Laminations may be partly of organo-sedimentary (algal) origin. Some laminations are channeled into units below. Prominent cleavage offsets Ianinae. Specimen stained with Alfzarin Red S. Negetive print of acetate peel, $\mathbf{x}$ 2.6. Peel from specimen collected at the outcrop shown in figure 30 . 
61

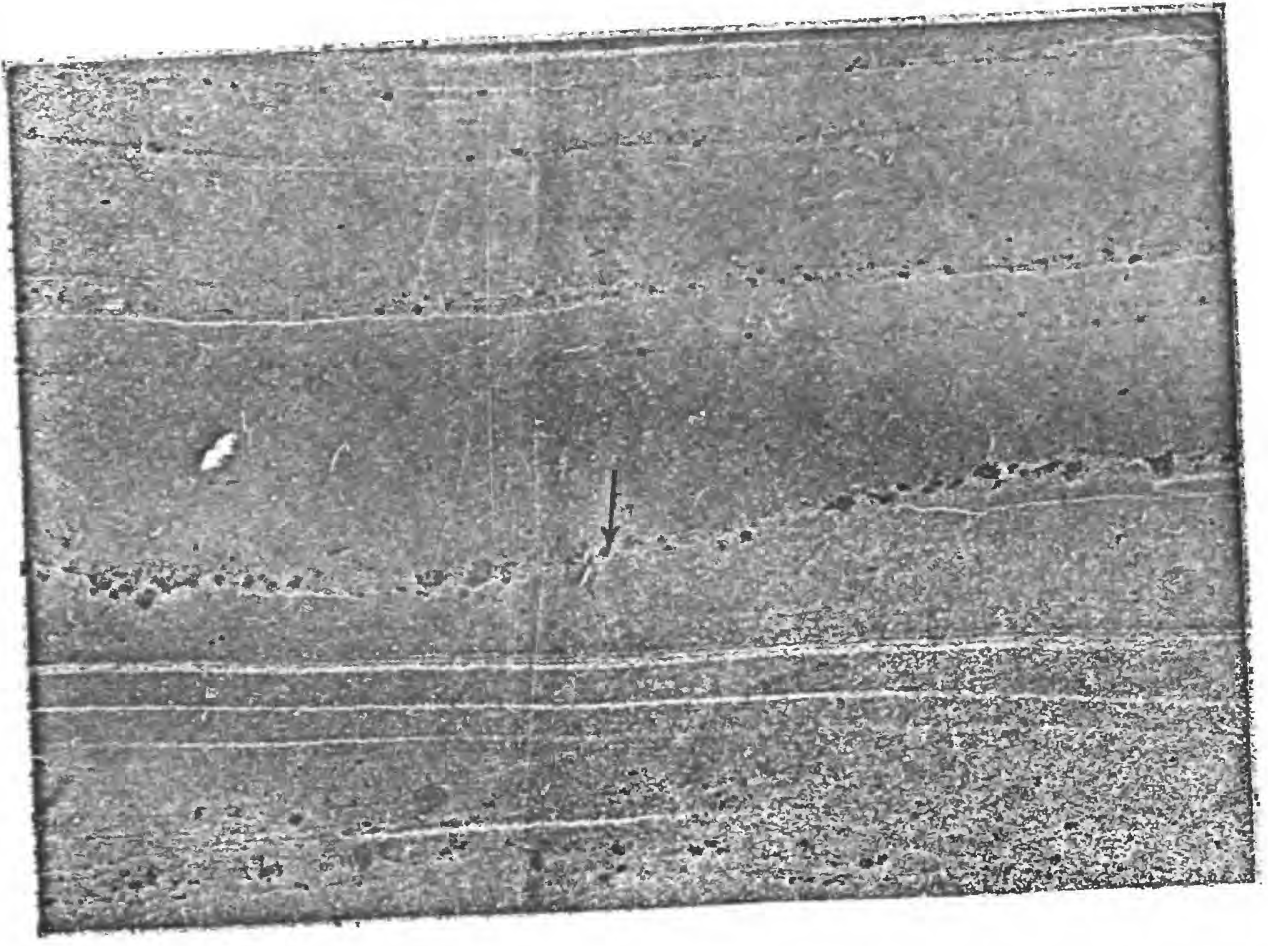

Figure 28. Graded cycles in thin-bedded and laminated sandy calcarenites and calcisiltites (quartz grains are dark) Bossardville limestones (Iight). Note small scoured base at arrow. Stained with Limestone, abandoned south Croasdale quarry. Specine 2.6 . 


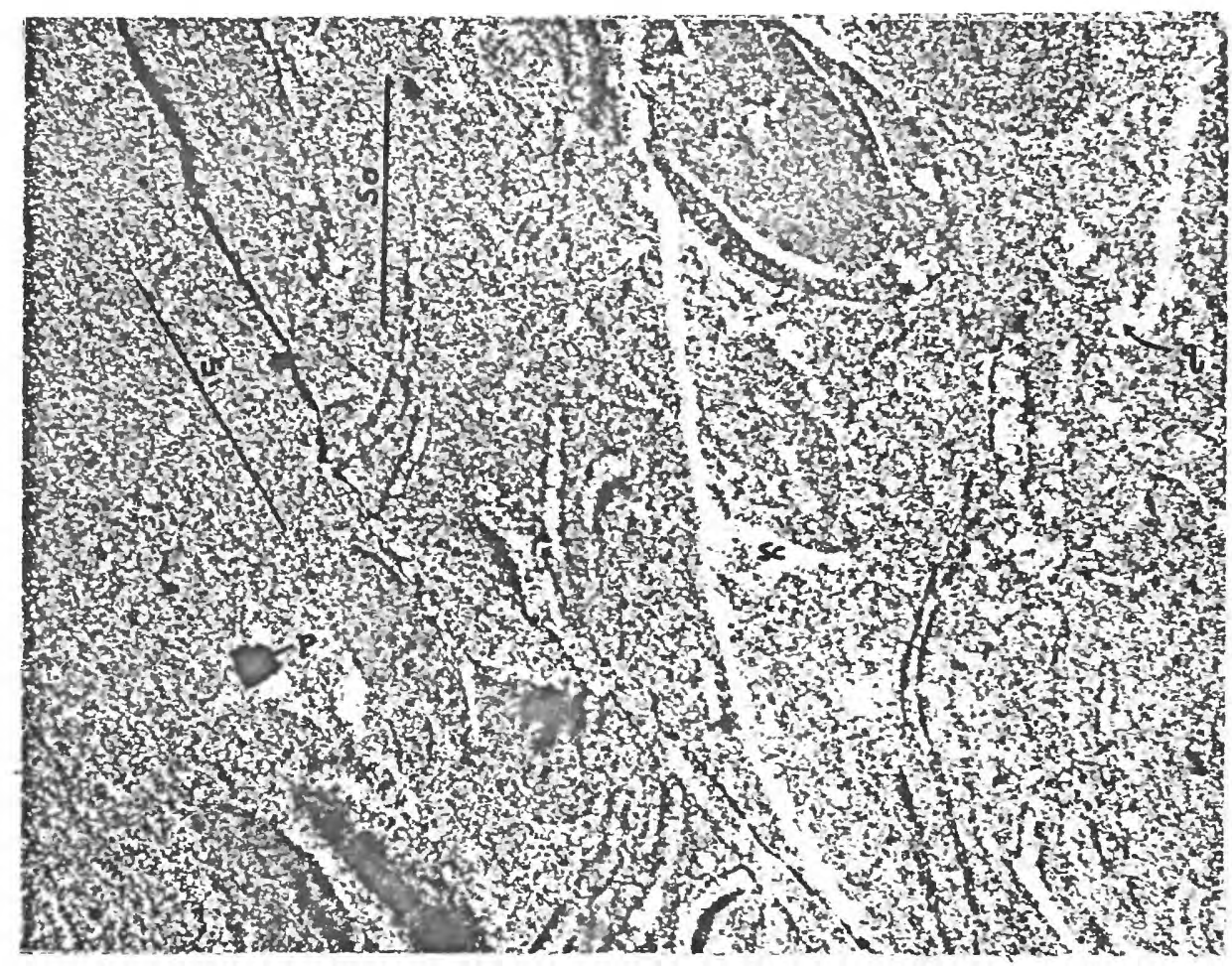

Figure 29. Photomicrograph (plane-polarized light, X43) of finely bedded ostracode-biomicrudite and micrite, Bossardville Limestone, south Croasdale quarry. Minor silt-sized to very fine sand-sized quartz (q) with etched borders and pyrite cubes ( $p$ ) with calcite grown in pressure-shadow areas. Bedding $\left(S_{0}\right)$. Note offset and solution of fossils along some cleavage planes $\left(S_{7}\right)$. Small patches of sparry calcite (sc) were probably produced by neomorphism of micrite. 
In the northorn Croasdale quarry at the east end of Godfrey Ridge, two mud-crack units, each nearly 6 feet thick, are separated by about 10 feet of laminated beds (fig. 30). Dark-gray calcareous shale occurs as fillings between the columns. The mud cracks were compressed during folding, and it is probable that the shale fillings were remobilized during the formation of rock cleavage, thus accentuating the shape of the columns.

\section{Decker Formation}

Rocks herein assigned to the Decker Formation were originally called Decker's Ferry by White (1882) and later included in the Keyser Iimestone or Keyser Group, along with the overlying Rondout Formation and Manlius Limestone (Depue Limestone Hember of the Coeymans Formation of this report) by Swartz (1929) and later workers. The confused history of nowenclature was reviewed by Epstein and others (1967) who defined the Decker Formation as consisting of two members: a limestone facies northeast of the Wallpack Center area, New Jersey (Clove Brook Member); and a sandier facies to the southwest (Hallpack Center Member). Because only the Wallpack Center facies is present in the Stroudsburg quadrangle, the rock unit is herein referred to as the Decker Formation. The type locality of the Wallpack Center Member is I mile northeast of Wallpack Center, N. J., on the southeast slope of Wallpack Ridge, where it consists mainly of 82 feet of calcareous, partly conglomeratic sandstone and arenaceous limestone.

In the Stroudsburg quadrangle, the Decker Formation is exposed on the south slope of the east end of Godfrey Ridge (where the boundary with the underlying Bossardville Iimestone is gradational) and near 


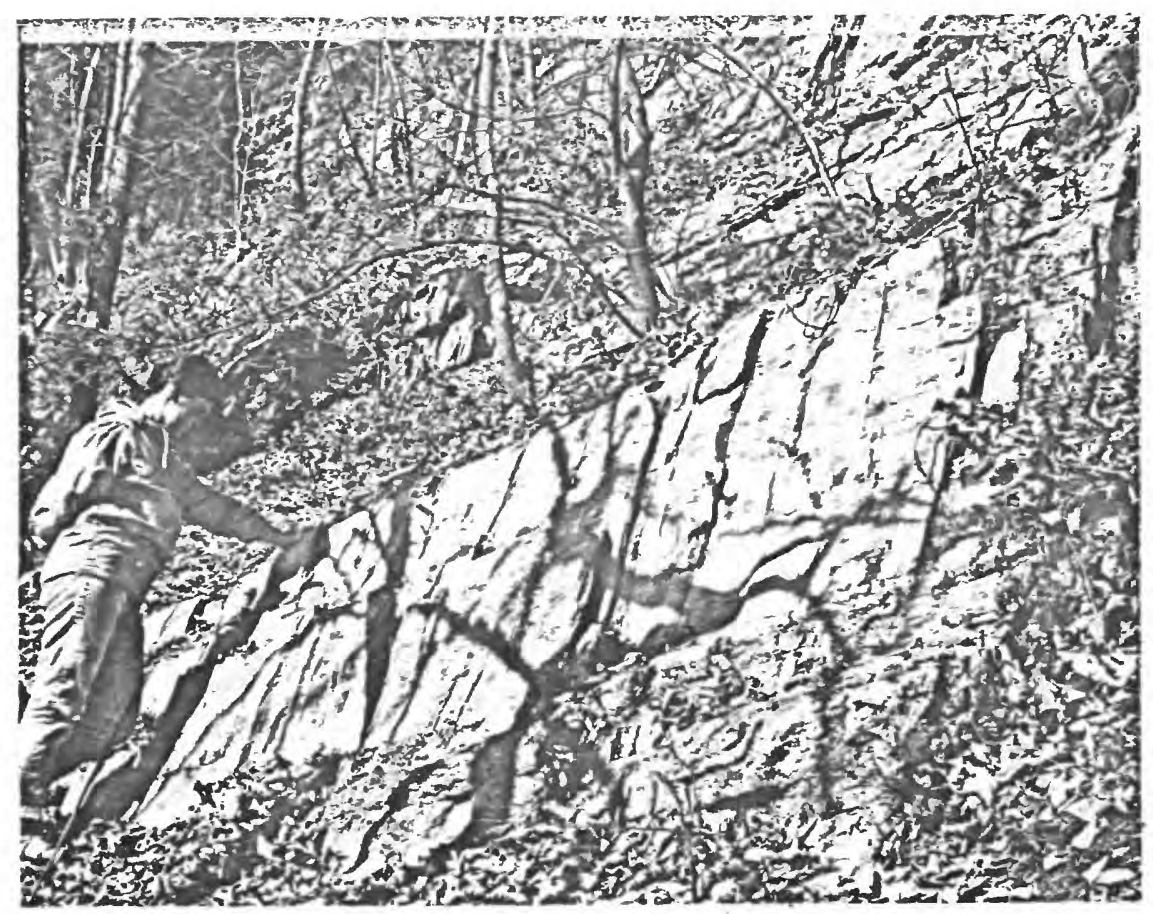

Figure 30. Compressed mud-crack columns, more than 5 feet Iong, in the lower beds of the Bossardville Limestone at the abandoned north Croasdale quarry, about 0.5 mile southwest of Minisink Hills, Pa. 
Stornville. It consists of medium-gray to medium-dark-gray, fine- to medium-grained, arenaceous and argillaceous, fossiliferous limestone (fig. 31) and calcareous finem to coarse-grained sandst one and conglomerate with rounded to subangular quart $z$ pebbles as much as 1.5 inches long. Both sandstones and conglomerates are crossbedded and planar-bedded. These bedding characteristics are best observed in near-vertical beds at the east end of Godfrey Ridge at an altitude of 450 feet. The Decker characteristically weathers grayish orange, a valuable aid in distinguishing it from the similar Stormville Nember of the Coeymans Formation. T'he Decker is 84 feet thick at the south Croasdale quarry. It is the youngest undisputed Silurian unit in eastern Pennsylvania, bearing Eccentricosta jerseyensis and halysitiós. Other poorly preserved brachiopods and corals were seen.

\section{SILURIAN AND DEVONIAN}

The location of the Silurian-Devonian boundary in eastern Pennsylvania has been a problem for many years (see Epstein and others, 1967, for terse summary). The upper part of the Depue Limestone Member of the Coeymans Formation contains a conodont fauna with Icriodus woschmidti Ziegler and Lonchodina cristagalli Ziegler, index fossils for the earliest Devonian (A. G. Epstein, oral commun,, 1970). The Decker Formation is Silurian. No conodonts have been found in the Rondout Formation in the Stroudsburg area, and, to date, no definitive work has been done on the megafossils in the Rondout. Thus, the Rondout is either Silurian or Devonian, or the systemic bourdary lies within it. 


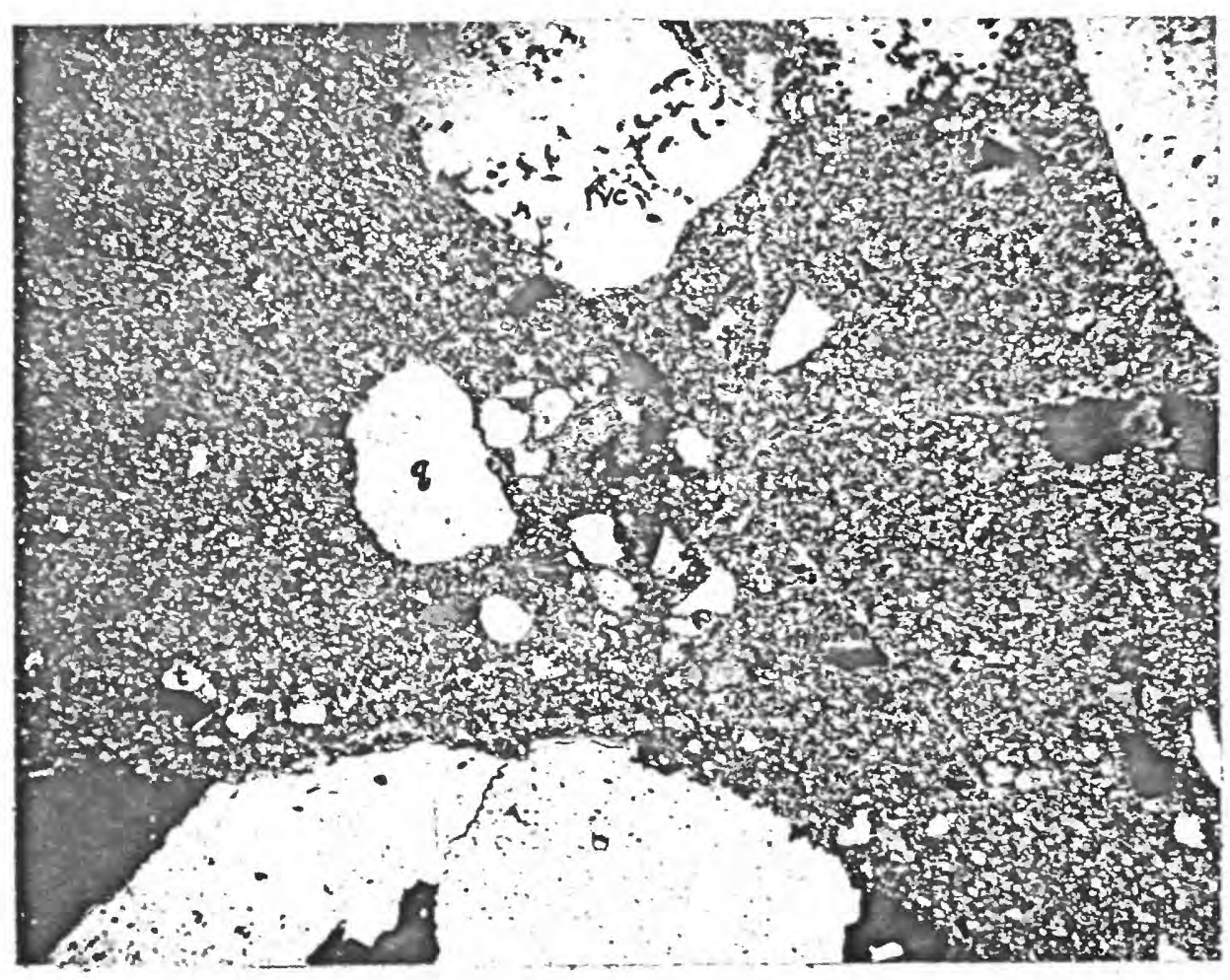

Figure 31. Photomicrograph (crossed polarizers, X 43) of conglomeratic sandy calcisiltite, Decker Formation, south Croasdale quarry. Quartz (q) is generally rounded to subangular and has etched borders as do the rare grains of plagioclase feldspar. Quartz in lower part of photograph is part of a composite quartz pebble $5 \mathrm{~mm}$ long. The large grains float in a silt matrix of limonitic calcite (70 percent of total sample), quartz, and lesser muscovite. Note subround tourmaline $(t)$ and vernicular chlorite (vc) in quartz. 
Clarke and Schuchert (1899) named the Rondout Waterlime for rocks overlain by the Manlius Limestone and underlain by Salina beds at Rondout, N. Y. The subsequent nomenclatural history of rocks assigned to the Rondout is surmarized by Rickard (1962) and Epstein and others (1967). The Rondout was divided into three members in eastern Pennsylvania by Epstein and others (1967). These are, from base upwards, the Duttonville, Whiteport Dolomite, and Hashipacong. Exposures of the

- Rondout are rare in the Stroudsburg quadrangle. It is completely exposed at only one locality-malong the south bank of Brodhead Creek, 1,500 feet southwest of where U.S. Interstate Highway 80 crosses the creek in the northeast corner of the quadrangle. The strata are vertical and the Rondout is 28.5 feet thick (measured section 3). The contact with the Decker Formation is abrupt.

The Whiteport Dolomite Kember was called the Stormville hydraulic cement bed by white (1882) and was cited to be 5 to 10 feet thick. The Decker Ferry Limestone of White, about 20 feet thick, is the Duttonville Nember of this report. At Stormille, Swartz and Swartz (I94I) measured 14.5 feet of their Rondout Limestone in a partially concealed section. They also report 11 feet of Rondout at the south Croasdale quarry. Herpers (1951) measured 10 feet at the same place. O'Neill (1941) described and figured the mud cracks in the Whiteport liember near Stomille but identified the rock as Bossardville Limestone.

Duttorville Member

The Duttonville Hember was proposed by Epstein and others (1967) for 30 feet of gray, fine-grained limestone, calcareous shale, and 
midcracked dolonite in the William Nearpass quarry, 1.8 miles southwest of Duttonville, N. J. In the Stroudsburg quadrangle, the Duttonville is 12 to 17 feet thick and consists of medium-gray, medium-gray to yellowish-gray-weathering, very fine to fine-grained, laminated to fine-bedded, argillaceous, ostracode-rich limestone and mudcracked calcareous shale. Near the middle of the member is a 1-foot-thick biostromal limestone with abundant ccrals and brachiopods (fig. 32). Paleontologic studies of this bed may aid in determining the age of the Rondout Formation in eastern Pennsylvania.

The Duttonville exposed along an overgrown lane on the northeast slope of Godfrey Ridge at an altitude of 500 feet, overlooling U.S. Interstate Highway 80 , about 2,000 feet west of Minisink Hills is yellowish-gray-weathering, very fine grained, dense, mediuri-gray limestone. Slabs with multitudes of smooth-shelled ostracodes lie nearby. A similar exposures is in a field 1,400 feet northeast of the church at Stormville, 250 feet south of Cherry Valley Road. Whiteport Dolomite Member

The Whiteport Dolomite Member of the Rondout Formation was named by Rickard (1962) for It feet of buff-reathering argillaceous and calcitic dolomite near Whiteport, N. Y.

In the Stroudsburg quadrangle, the Whiteport is 7 to 9 feet thick and is a medium-gray to dark-gray, yellowish-gray to grayish-orangeweathering, very fine grained, slightly argillaceous, massive, pyritic, ferroan dolomite. It characteristically is mudcracked (fig. 33) and laminated (fig. 34). Its lower contact is sharp. Many writers have used the term "peth-stone" for the Whiteport, a 


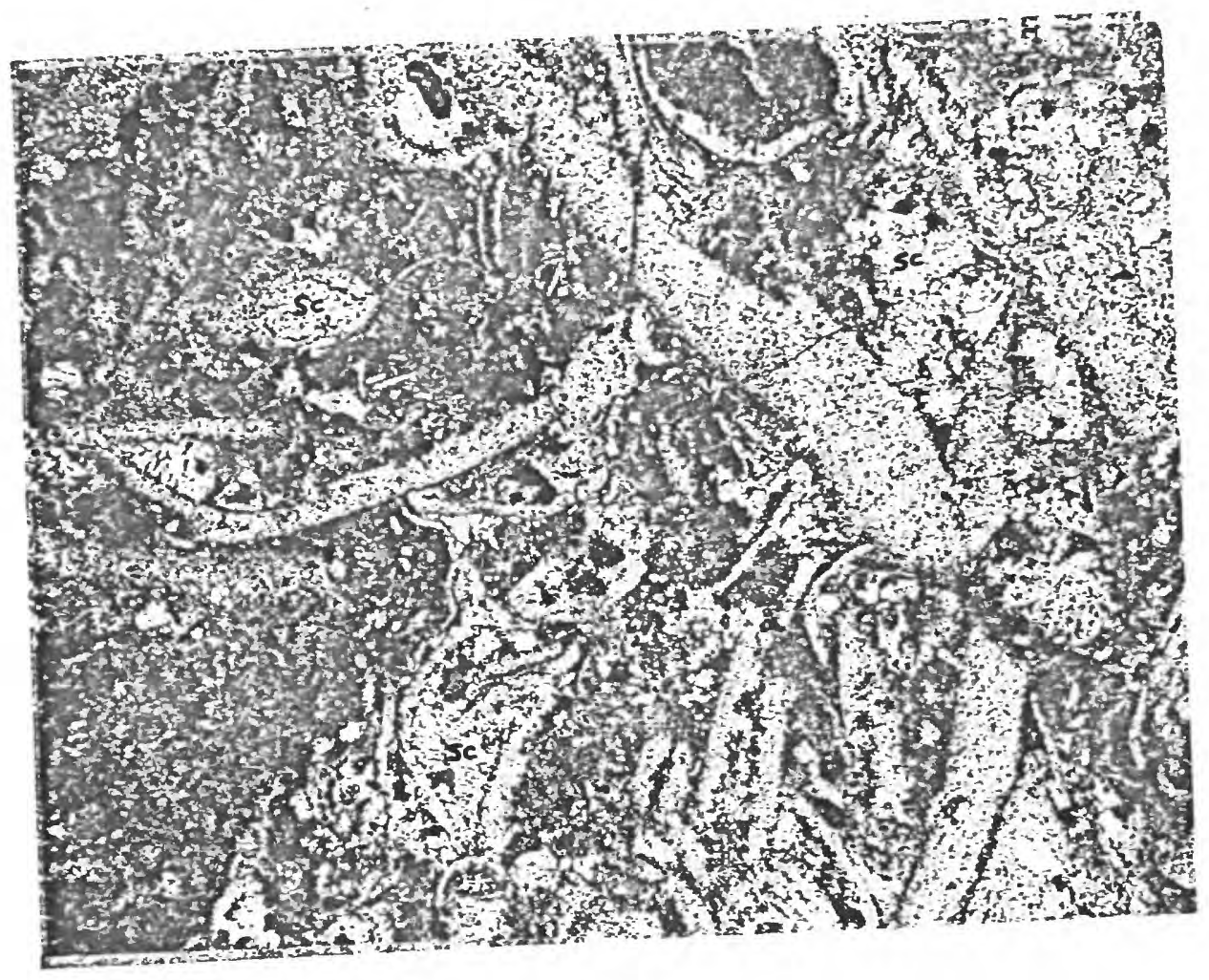

Figure 32. Photomicrograph (plane-polarized light, $\mathrm{X} 43$ ) of in the biostromal bed of the Duttonville liember of the biomicrudite in the unit 2 of measured section 3. Sparry calcite (Sc) occurs as pore filling in many of the ostracodes and brachjopod shell fragments. 


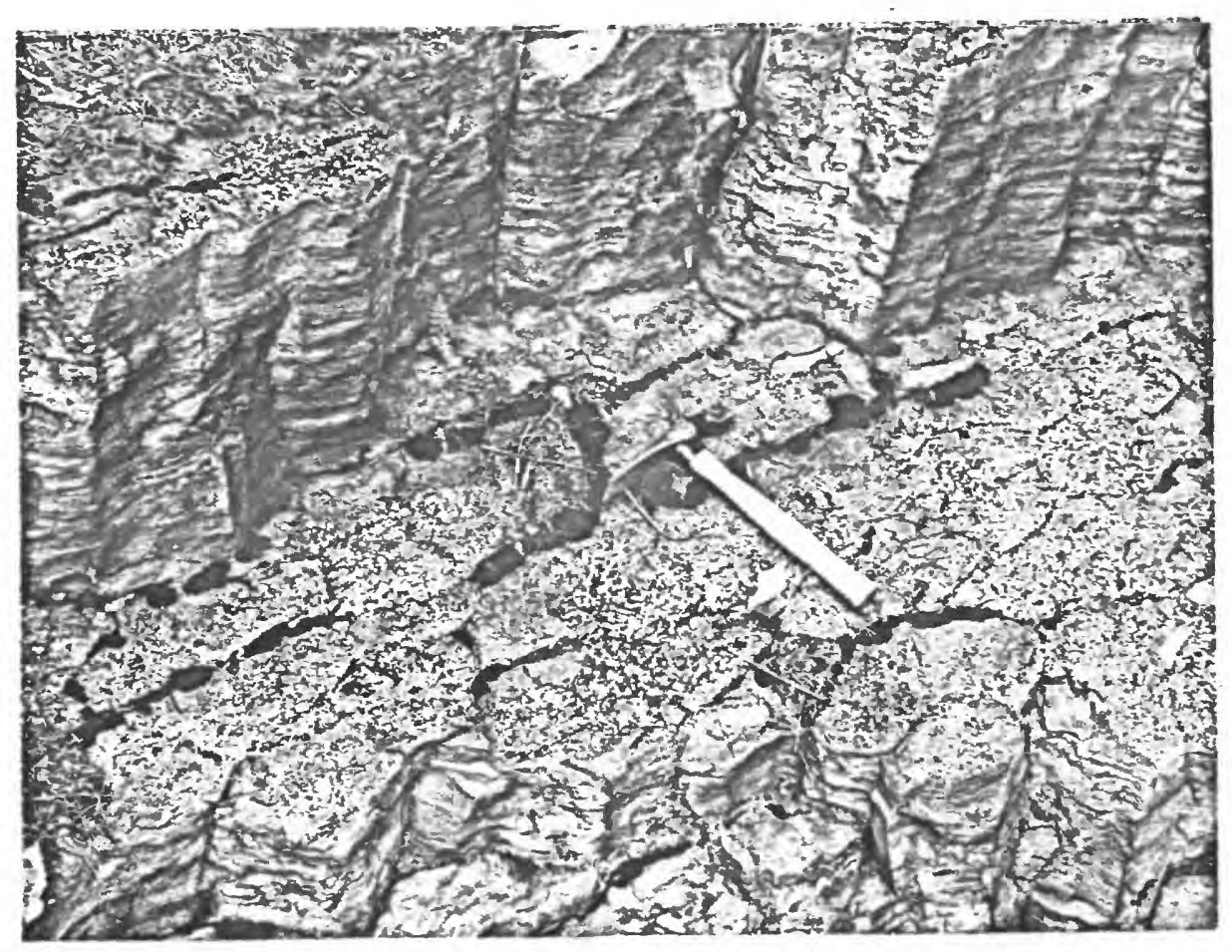

Figure 33. Mud cracks in the massive initeport Dolomite Member of the Rondout Formation in roadcut on north side of Cherry Valley Road, 2,000 feet northeast of the church in Stormville. The dolomite is laminated (see fig. 34) and dark-gray calcareous shale fills some of the interpolygon cracks. 
71

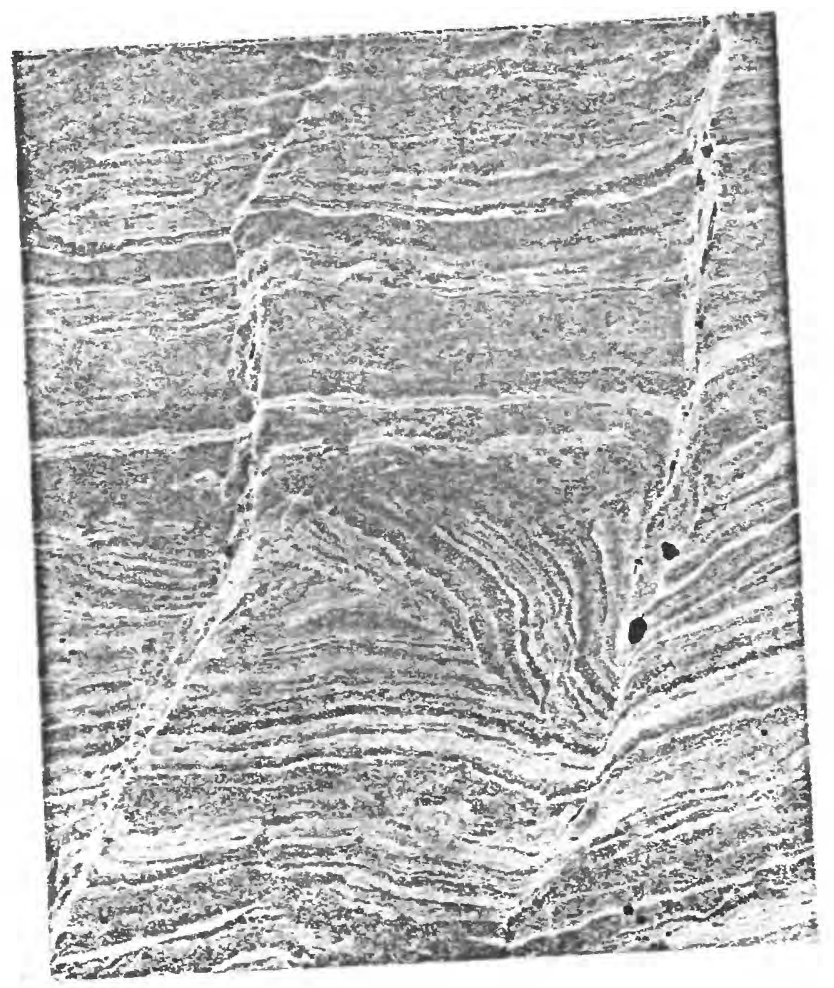

Figure 34. Laminated and mud-cracked ferroan dolomite from outcrop shown in figure 33. Rock cleavage is concentrated alone shale-filled cracks, offsetting the laminae. Note disrupted bed, a penecontemporaneous soft-rock feature possibly due to slumping during a storm. Negetive print of acetate peeI, X 2.4. 
usage originally employed by Cook (1863; p. 159) as "a 100 al name, applied to a thickbedded argillaceous limestone, light-blue color, fine-grained, containing iron pyrites in small and detached crystals. It is used to make water-lime when burned." The buff (yellowish gray to grayish orange) weathering color of the peth-stone" is distinctive, and is due to weathering of the ferrous carbonate in solid solution in the dolomite (Pettijohn, 1957, p. 421). The composition of the Whiteport, determined by averaging five analyses given by White (1882, p. 136,137 ), is $\mathrm{CaCO}_{3}, 39$ percent; $\mathrm{MgCO}_{3}, 25$ percent; $\mathrm{SiO}_{2}, 22$ percent; iron oxide, 4.4 percent; $\mathrm{Al}_{2} \mathrm{O}_{3}, 4.4$ percent; $S$ and $P,<0.1$ percent.

\section{Mashipacong Member}

The type section for the Mashipacong Member is the William Nearpass quazry, 1.8 miles southwest of Duttonville, N.J., where it consists of fine-grained argillaceous limestone and calcareous shale (Epstein and others, 1967). Mashipacong Island is in the Delaware River, 1.7 miles west-northwest of the type section.

In the Stroudsburg quadrangle, the Mashipacong is light-gray to medium-dark-gray, medium-gray to light-olive-gray weathering, fine- to medium-graired, argillaceous, laminated to fine-bedded limestone and fissile mudcracked shale. It is 8 feet thick at the east end of Godfrey Ridge. The lower contact is sharp. Mud-cracked shaly limestone crops out in an excavation at 500 feet altitude, 400 feet southwest of the north Croasclale quarry. The polygons are deformed and they are nearly $I$ foot wide. 
DEVOMIAN

\section{Helderberg Group}

The Belderberg Group, named for Lower Devonian rocks in the Helderberg Mountains, W.Y., was first adequately described by Clarke and Schuchert (1899). Nowenclatural problems and regional relations of the Relderberg Group are given by Swartz (1929), Swartz and Swartz (1941), Richard (1962), and Berdan (1964). In the Stroudsburg area, the Helderberg is about 325 feet thick and is divided into the followIng formations, in ascending order: Coeymans Fornation, New Scotland Formation, Min1sink Limestone, and Port Eren Shale (Epstein and others, 1967). The group is part of Rogers' (1858) Scalent, Pre-kertdian, and Meridian Series, and is the upper part of Hitte's (1882) Lower Helderberg Formation.

The Helderberg Group is best exposed in the vicinity of Minisink Hills, especially in roadcuts where U.S. Interstate Highway 80 cuts through Godfrey Ridge (fig. 35). Lithologic details are given in measured sections 3 to 7 . Faunal lists are presented by Willard (1938).

\section{Coeymans Formation}

Clarke and Schuchert (1899) named the Coeymans Formation for strata between the Kanlius and New Scotland Limestones at Coeywans, N.Y. White (1882) included strata in eastern Pennsylvania in his Storraille Conglomerate and LImestone which were later correlated w1th the Coeywans by Grabau (1906): Epstein and others (1967) have rederined the Coeywans Forwation in eastern Pennsylvania, New Jersey, and southeasternmost New Yoris. In the Stroudsburg quadrangle, it consists of approximately 75 feet of gray fossiliferous limestone, arenaceous 


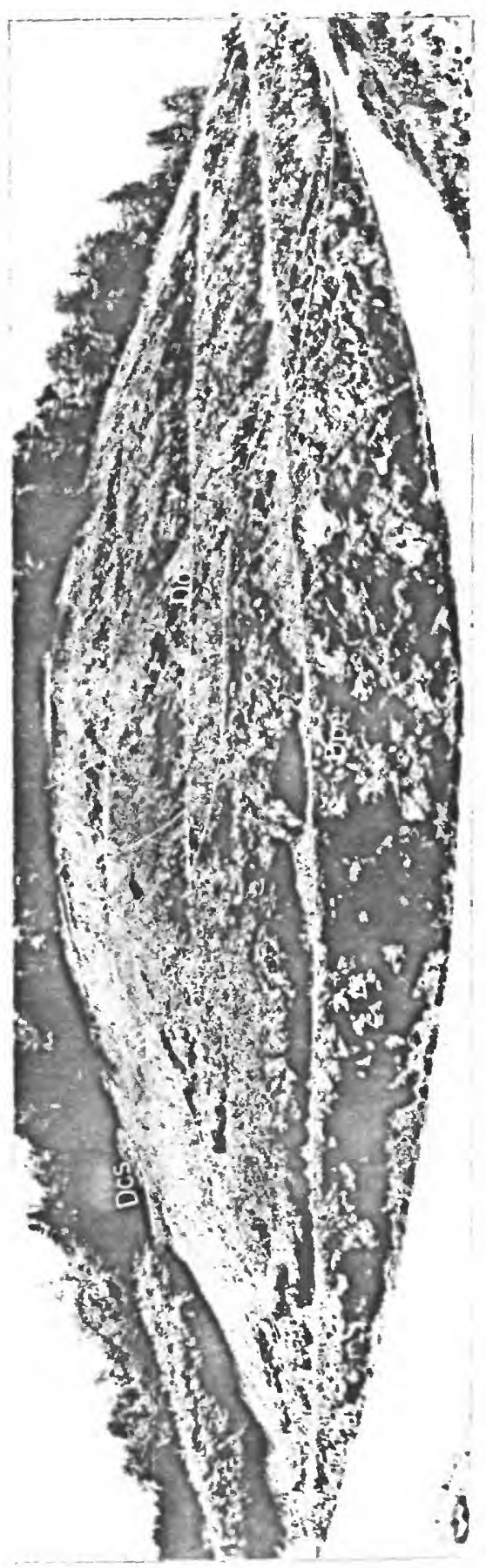

. कि융 홈댕 हो

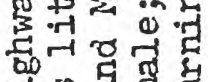
证 的领

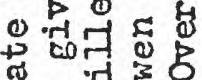
的实 o \& 5010 स H 0 范 i $\Rightarrow$ व 以

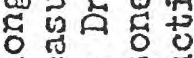

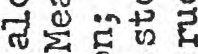

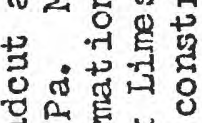

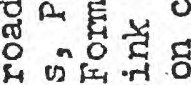
न 7 न

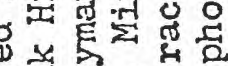
ज म ० क्रें ब न्व

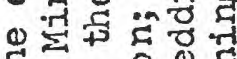
मी स तु 0 स्

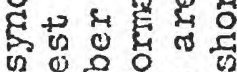
प 0 है 20 ठ . में 0 द्रु क न म्नत्

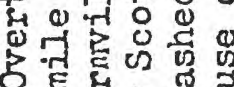
ठ Е

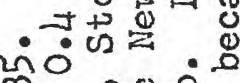

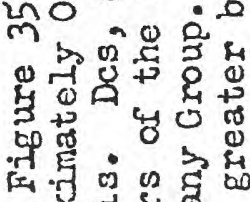

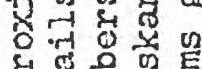
भूत م. \& 
limestone, calcareous sandstone, and calcareous quartz-pebble conglomerate. These rocks have been divided into four members, winich are, from oldest to youngest, the Depue Limestone, Peters Valley, Shaimee Island, and Stormille.

Depue Limestone Mernber

Rocks of this lowest member of the Coeymans Formation in eastern Pennsylvania were placed in the Hanlius Formation by Swartz $(1929,1939)$, Willard (1938), Swartz and Swartz (1941), and others. However, these rocks are not similar to the unevenly bedded, fine- to medium-grained "ribbon" limestone with thin yellowish-gray shale partings of the lianlius of New York State, and were placed in the Coeymans Formation as the Depue Limestone Hember by Epstein and others (1967). The type section of the Depue is about 0.5 mile southwest of Sharmee on Delaware, $\mathrm{Pa}_{\text {., }}$ where it consists of 13 feet of slightly arenaceous and argillaceous, fine-grained, evenly bedded limestone with scattered coarse-grained limestone. Depue Island is in the Delaware River east of Shawnee on Delaware. The Depue Member of the Coeymans Formation grades laterally into the Thacher Menber of the Manlius Limestone near Hainesville, N.J. The Depue Limestone Member is 18 feet thick on Brodhead Creek in the northeast corner of the Stroudsburg quadrangle (measured section 3) where it consists of medium-gray to dark-gray, medium-gray to mediumlight-gray weathering,, slightly arenaceous and argillaceous, fine- to coarse- grained, slightly limonitic, evenly and fine-bedded, fossiliferous limestone that contains brachiopods, ostracodes (fig. 36), stromatoporoids, and corals. The contact between the Depue and underlying Rondout Formation is abrupt.

Good exposures are found along the orergrown lane west of U.S. 


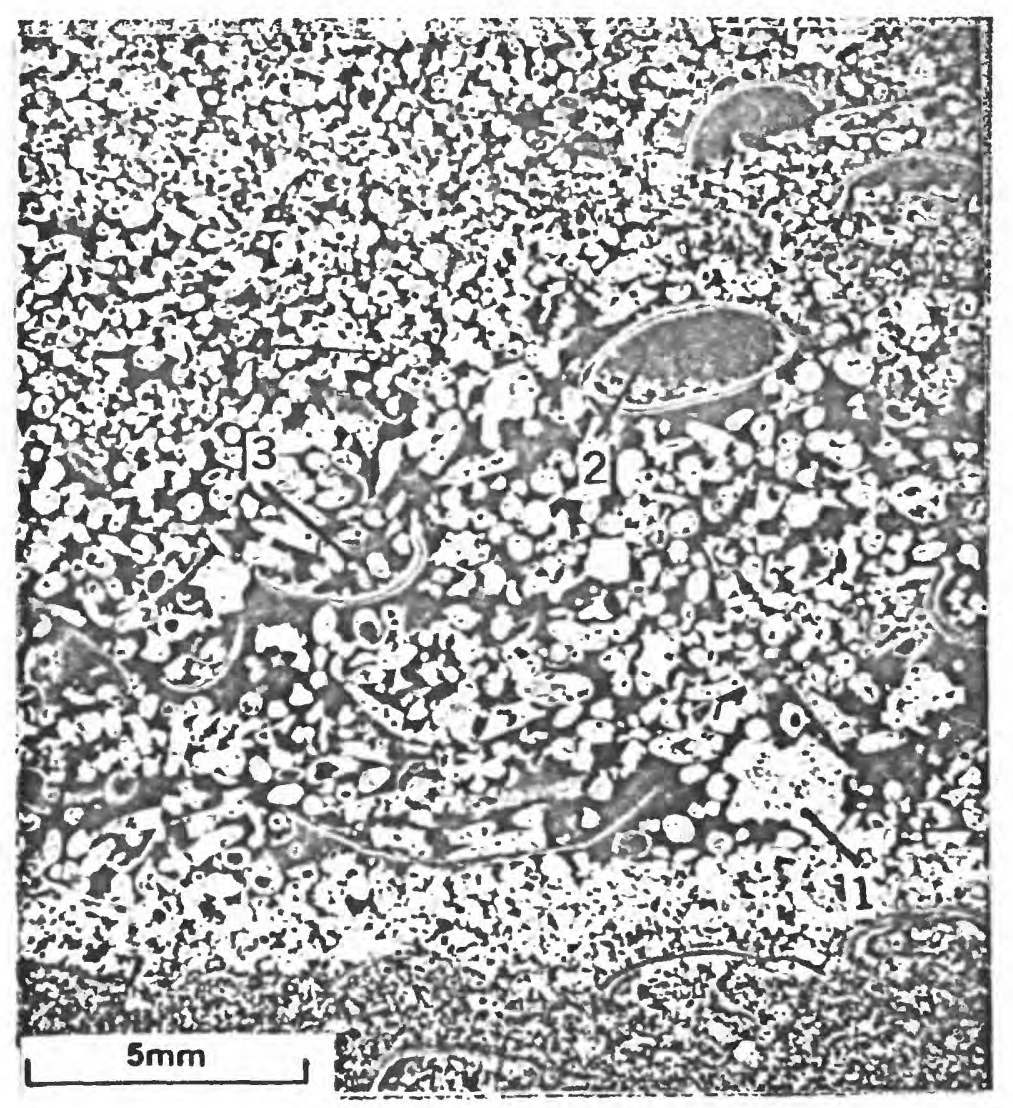

Figure 36. Negative print of a thin section of Depue Limestone Member of Coeymans Formation, from southeast bank of Brodhead Creek, approximately 0.1 mile above power dam (unit 5 of measured section 3). Silty and fine sand ost racode biosparrudite lies above a thin bed of fossiliferous calcareous quartz siltstone in which micrite fills interstices. The biosparrudite contains intraclasts from underlying siltstone (1). Note sparry calcite beneath ostracode umbrella (2) and concave upward ostracode carapaces filled with debris (3). Pellets $(4)$ are abundant. Sparry calcite (dark areas) occurs as pore filling and replacement of micrite (neomorphism) and some quartz and fossil debris. Micrite comprises about 40 percent of rock. A trace of plagioclase feldspar is present in the sample. 
Interstate 80 at an altitude of 500 feet and in an excavation at an altitude of 500 feet, 400 feet southrest of the north Croasdale quarry. In the Stomrille area, the Depue is seen only in small exposures except for a small quarry on the south slope of Godfrey Ridge, 2,000 feet northeast of the Stormilile church about 50 feet above the Cherry Valley Road. In this quarry gray ribbony limestone with ostracodes and Favosites are found.

Peters Valley Hember

The Peters Valley Hember of the Coeymans Formation is about 5 feet thick in the Stroudsburg quadrangle and consists of medium-gray, medium-light-gray-weathering, very arenaceous to conglomeratic (quartz pebbles as much as $\frac{1}{4}$ inch long), fine- to medium-grained, slightly limonitic, massive, crossbedded, fossiliferous 1 imestone and calcareous sandstone. Fossils include Gypidula coeymanensis, other brachiopods, stromatoporoids, and corals. The lower boundary is gradational. The member is exposed along Brodhead Creek (measured section 3), the east end of Godfrey Ridge, and 2,200 feet northeast of Stormville church 140 feet above Cherry Valley Road.

Rocks of similar type 1.5 miles northwest of Flatbrookville, N. J., serve as the type section (Epstein and others, 1967) for the member. It is named after Peters Valley, N. J.

Shawnee Island Member

Rocks of the Shawnee Island Member are, for the most part, the Coeymans limestone of many previous workers in eastern Pennsylvania. The Sharmce Island was defined by Egstein and others (1967) for 56 feet of argillaceous and arenaceous, fine- to medium-grained, cherty lime- 
stone, about 0.5 mile southwest of Shawnee on Delaware, Pa., just north of Shawree Island. This rock type is characteristic of the - nonbiohermil or interreef facies which is the only facies exposed in the Stroudsburg quadrangle. Elsethe re in eastern Pennsylvania and New Jersey, several unbedded to massively bedded coarsely crystalline limestone bioherms have been found.

On the now-abandoned Erie Railroad grade west of Minisink Hills, more than 26 feet of Shawnee Island was reported by Willard (1938), 28 feet by Swartz (1939), and about 63 feet by Swartz and Swartz (1941). White (1882) measured 30 feet at this locality. White (1882) reported 50 feet and Swartz and Swartz (I9LI) assigned 66 feet to the partly concealed Shawnee Island Member at Stormille. The section at Stormille is too poorly exposed for measurement, but on Brodhead Creek (measured section 3), the Shawnee Island is 35 feet thick. It is exposed in many other places in the Stroudsburg quadrangle (see geologic map of Godfrey Ridge, pl. III, and also measured sections $4-6)$.

The Shawnee Island is medium-gray to medium-dark-gray, mediumlight-olive-gray to mediun-gray-weathering, fine- to medium-grained, arenaceous and argillaceous, slightly limonitic, irregularly bedded, locally burrowed fossiliferous limestone (fig. 37). Gypidula coeymanensis is abundant and weathers in relief on bedding surfaces. Other fossils include crinoid columnals, bryozoans, and corals. The upper 10-25 feet contains nodules and lenses of dark-gray chert. The member is sandier in the western part of the quadrangle. The boundary with the underlying Peters Valley Member is gradational. 


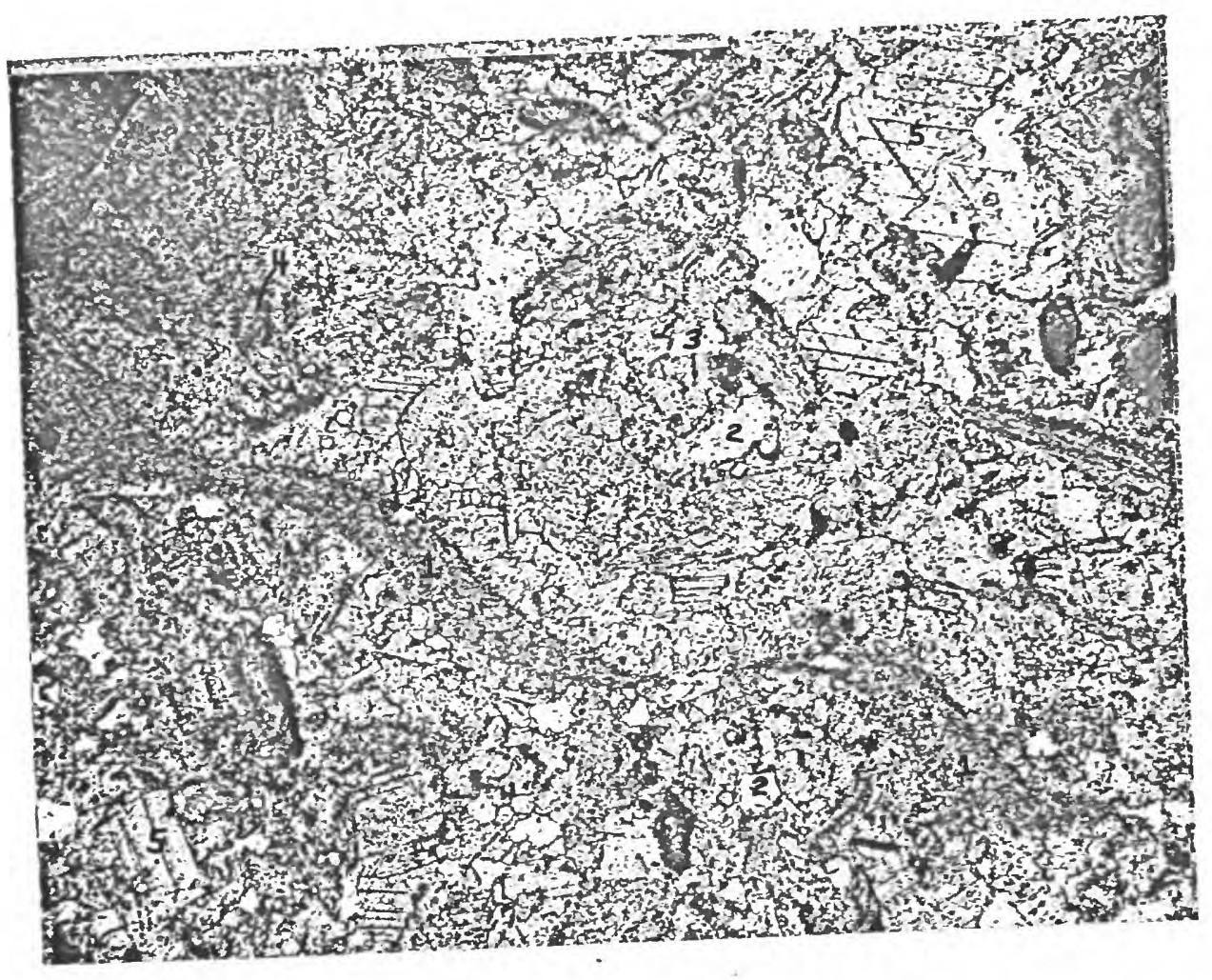

Figure 37. Photomicrograph (plane-polarized light, X 43) of sandy biopelsparrudite in Sharmee Island liember of Coymans Formation, unit 7 of measured section 3. Note cross section of Gypidula coeynanensis (1), etched quartz (2), and placioclase foldspar (3), pellets (4), and sparry calcite (5). 
White (1882, p. 132) named the Stormville Conglomerate for "a series of alternating beds of quartz pebble rock, and pebbly limestone" lying between his Stormville limestone below and Stormville Shales above (New Scotland through lower part of Oriskany Group of this report). At Stormille, Pa., the type locality, White measured 45 feet, whereas Swartz and Swartz (1941), upon reexamining the section, reported only 14 feet referrable to the Stormille. Nearby, at Hartmans Cave, in an incomplete exposure, the Stormville is nearly 25 feet thick (measured section 5). On Brodhead Creek near Minisink Hills, where White (1882) measured 17.5 feet and Swartz (1939) and Swartz and Swartz (1941) measured 14 feet, the Stormville Meraber is nearly 17 feet thick (measured section 6). The Stormville is at least 26.5 feet thick near the intersection of Cherry Valley Road and State Route 191 (measured section 4), where Swartz and Swartz (1931, p. 646) assigned these rocks to the Decker Ferry.

The Stormville was adopted as a member of the Coeymans by Epstein and others (1967). The reference section is at Hartmans Cave (measured section 5). It is comparatively well exposed in the Stroudsburg quadrangle, generally forming easily traced ribs of medium-gray to medium-light-gray, light-olive-gray- to medium-lightgray-weathering, fine- to coarse-grained, conglomeratic, calcareous and planar-bedded, lenticular, partly limonitic sandstone and quartz-pebble conglomerate with rounded pebbles as much as I inch long (fig. 38), and fine- to coarse-grained arenaceous limestone (fig. 39). It is fossiliferous, containing scattered rugose corals, stromatoporoids, crinoid columnals, and Gypidula coeymanensis. It 


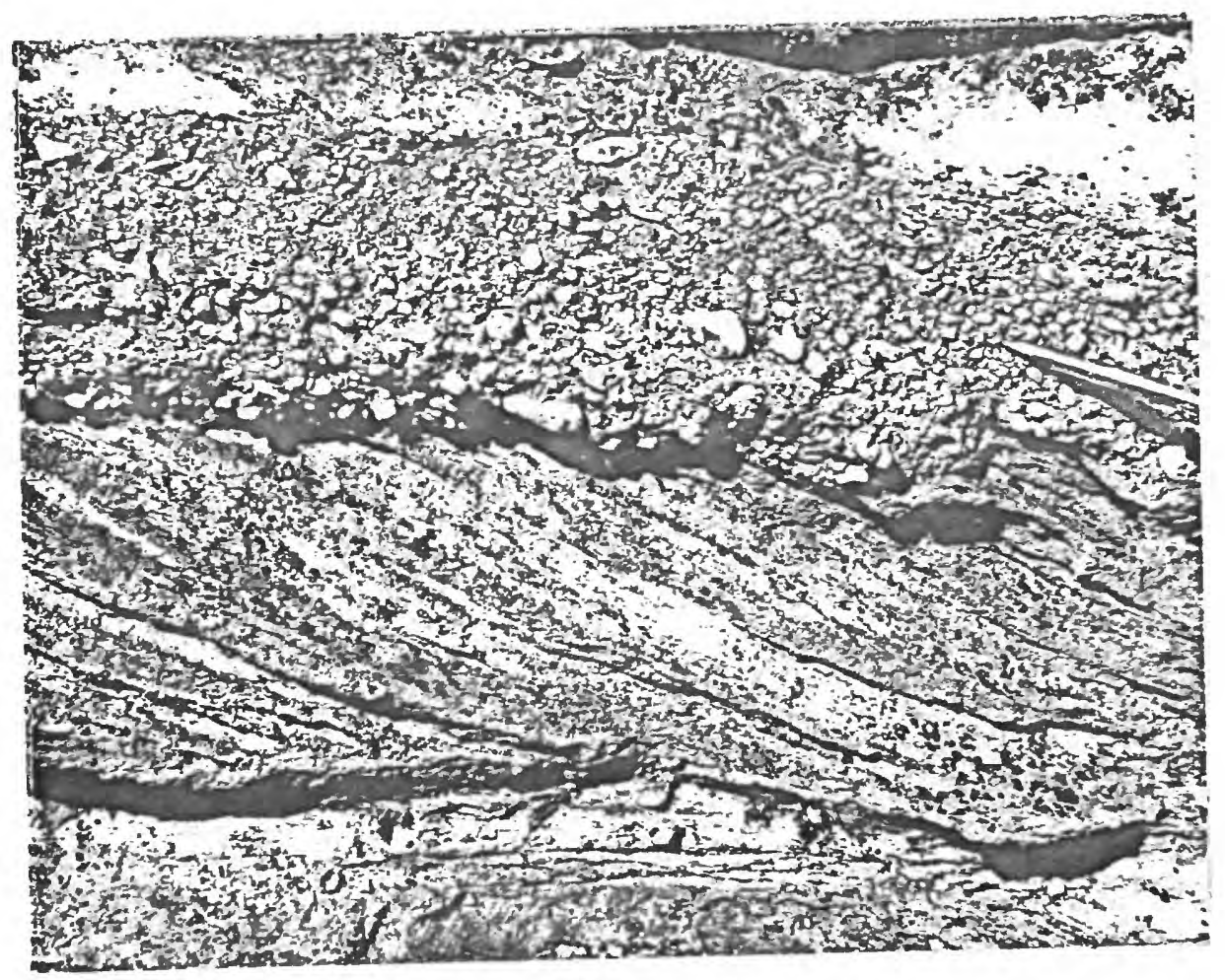

Figure 38. Stornville Member of the Coeymans Formation, intersection of State Highway 191 and Cherry Valley Road, 2.l! miles northeast of Stormille, $\mathrm{Pa}$. From bot tom to top: laminated to planar-bedded quartzose crinoidal fine- to coarse-grained limestone; crossbedded calcareous sandstone; and planar-bedded calcareous quartz-pebble conglomerate with pebbles as much as 1 inch long and scattered crinoid columnals (at pen point). Unit 5 of measured section 4. 


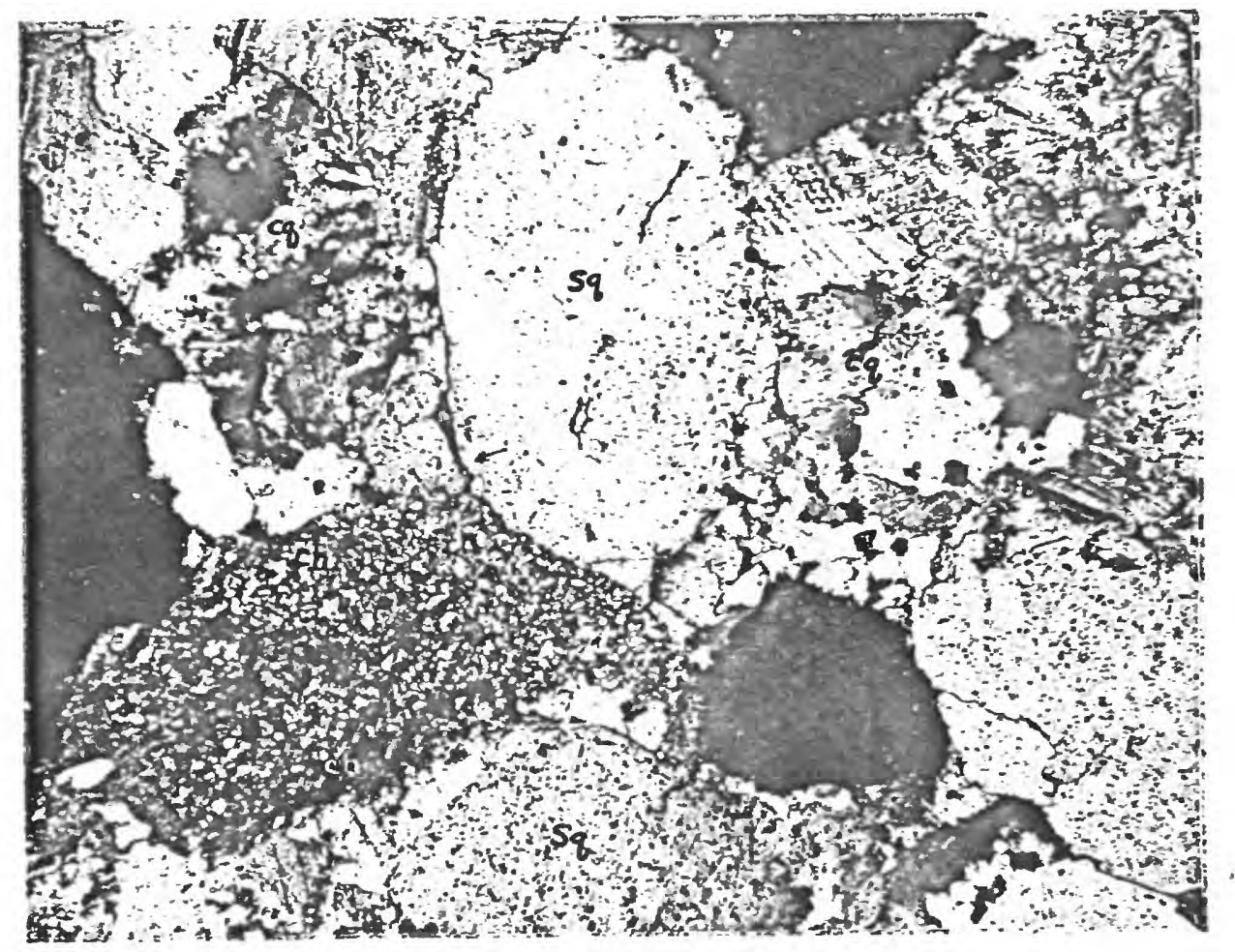

Figure 39. Photomicrograph (crossed polarizers, X 43) of very coarse grained calcareous orthoquarticite made up of rounded to subangular quartz and lesser chert (ch) in a sparry calcite cement, Stornville Member of Coeymans Formation, unit 4 of measured section 6 . The quartz grains are either single grains with undulose extinction (sq) or composite grains (cq), implying a presolved sediment ary quartzite or metaquartzite as well as a sedimentary source. Grain contacts are generally concave. Some quartz overgrowths were noted (arrow). 
rests with an abrupt erosional contact on the Shamee Island liember. Grabau (1906, p. 173) believed that this disconformable contact represents a marked break. However, based on paleoenviromment al considerations to be discussed later, and lack of fossil evidence to the contrary, only a slight hiatus is indicated.

\section{New Scotland Formation}

The lower part of White's (1882) Storinville Shales in eastern Pennsylvania is the New Scotland Shale of Willard (1938), Ner Scotland Shale and Limestone of Swartz (1939), and New Scotland Formation of Swartz and Sivartz (19/4). The name New Scotland was carried in from eastexn New York where it was originally used by Clarke and Schuchert (1899). The New Scotland was divided into two members, the Flatbrookville below and Maskenozha above, folloming the earlier recognition of its bipartite nature by Swartz (1939) and Sirartz and Swartz (194l). In the northeast corner of the Stroudsburg quadrangle, the New Scotland is about 75 feet thick (measured section 6).

\section{Flatbrookville Member}

The Flatbrookville was proposed by Epstein and others (1967) for siliceous and calcareous shales, about 3.5 miles northeast of Flatbrookville, N. J., where it is 17.5 feet thick. The Kalkberg was used for rocks in the Flatiorookville in eastern Pennsylvania by Swartz (1939) and Swartz and Swartz (194I), but Epstein and others (1967) showed that the Kalkberg of New York laterally grades into strata of the Stornville and Shawnee Island Member of the Coeymans Formation near Wall pack Center, N. J.

In the Stroudsburg quadrangle, the Flatbrookville is 33 feet thick 
(measured section 6). A similar thickness was reported by earlier workers mentioned above. The member consists of dark-gray, - medium-gray- to mediun-light-gray-weathering, silty, fossiliferous shale with about 10 pericent nodules, lenses, and beds of medium-gray to medium-dark-gray, fine-grained, argillaceous, fossiliferous limestone, containing coral fragments, brachiopods, bryozoans, trilobites, and ostracodes, and about 10 to 15 percent lenses and nodules of dark-gray chert. The lower contact is abrupt. It is very poorly exposed, as is the underlying Maskenozha Member. The best exposures are in the rinisink Hills area.

\section{Maskenozha Nermber}

The upper part of the New Scotland Formation was named the Maskenozha Member by Epstein and others (196́7) for Lake laskenozha, 5.5 miles northwest of the type section, which is about 3.5 miles northeast of Flatbrookville, N. J., and which contains about 45 feet of dark-gray siliceous laminated shale and scattered beds and lenses of argillaceous limestone.

On Brodhead Creek, the Maskenozha is 43 feet of dark-gray, mediumgray- to medium-light-olive-weathering, calcareous and siliceous, laminated shale with scattered pods and beds of medium-dark-ray to medium-gray fine-grained fossiliferous argillaceous limestone containing brachiopods, trilobites, bryozoans, corals, ostracodes, and crinoid columals. The basal contact is abrupt and is placed at the top of the lowest bed containing dark-gray chert.

\section{Minisink Limestone}

A thin argillaceous limestone in eastern Pennsylvania and New 
Jersey, between the New Scotland Forration and Port Even Shale, was somewhat hesitatingly identified as the Becraft Limestone by ifillis (1912), Swartz (1939), and Swartz and Swartz (1941). The uncertainty of this correlation was expressed by Willard (1953), and Epstein and others (1967) renamed the unit the Minisink Limestone because it is very different from the coarse-grained, very fossiliferous, gray and pink limestone of the type Becraft of New York.

There are scattered exposures of the Minisink in Godfrey Ridge, and the completely exposed 14 feet of the unit along U.S. Interstate 80 is the type section ( $\mathrm{fig} .35$, measured section 7). There are also good exposures near linisink Hills, the type locality (measured section 6). The Minisink is a medium-gray, light-tannish-gray-weathering, finegrained, argillaceous, irregularly bedded limestone, in beds as much as 3 feet thick, with thin interbeds of medium-dark-gray calcareous shale. Lenses of fossil hash, including corals, bryozoans, brachiopods, and crinoid debris, are common. A pulverized chamel sample from the type locality, when dissolved in dilute hydrochloric acid, showed that the Minisink is about 70 percent calcium carbonate. It appears to be more argillaceous in outcrop. The lower and upper contacts of the Minisink are sharp.

\section{Port Ewen Shale}

The shaly limestone near Port Ewen, N. Y., was named Port Ewen Limestone by Clarke (1903). The name was first used in Pennsylvania by Swartz (1929) and Iater by Willard (1938). Swartz (1939) and Swartz and Swartz (194I) measured 136 feet of Port Ewen Shale along the nowabandoned railroad grade west of Minisink Hills. In the complete 
exposure of the Port Ewen along U.S. Interstate Highway 80 (fig. 35), 151 feet were measured (measured section 7). Such thicknesses may be somewhat misleading because relative thinning of orthogonal thicknesses of shale beds jn the limb of the overturned fold along the hightray is about 50 percent.

The Port Ewen is a medium-gray, light-tannish-gray-weathering, calcareous, pyritic, laminated, irregularly bedded and burrowed shaly siltstone and silty shale (fig. 40). It is fossiliferous, especially in its upper 90 feet, containing brachiopods, corals, ostracodes, trilobites, crinoids, and some conodonts (fig. 4l). Slaty cleavage is conspicuous in all exposures.

\section{Oriskany Group}

Sandstone, chert, and siliceous and argillaceous limestone overlying the Port Ewer Shale were included in the Meridian Series of Rogers (1858) and in the Oriskany Sandstone and Stormville Shales of White (1882). The name Oriskany was first proposed by Vanuxen (1839) for the sandstones exposed at Oriskany Falls, N. Y.

The Oriskany Group in eastern Pennsylvania is transitional into the underlying Port Ewen through a sequence of interbedded chert, argillaceous limestone, and calcareous shale. Sandstone is more abundant upwards, and dominates the section at the top. Cleaves (1937) summarized the nomenclatural history of the Oriskany in Pennsylvania, recognized the twofold nature of the group, and divided it into the Ridgeley Formation above and the Shriver Formation below. The base was placed at the bottom of the lowest chert above the Port Ewen. Later, Cleaves (1939) was hesitant in assigning the lower Oriskany to the 


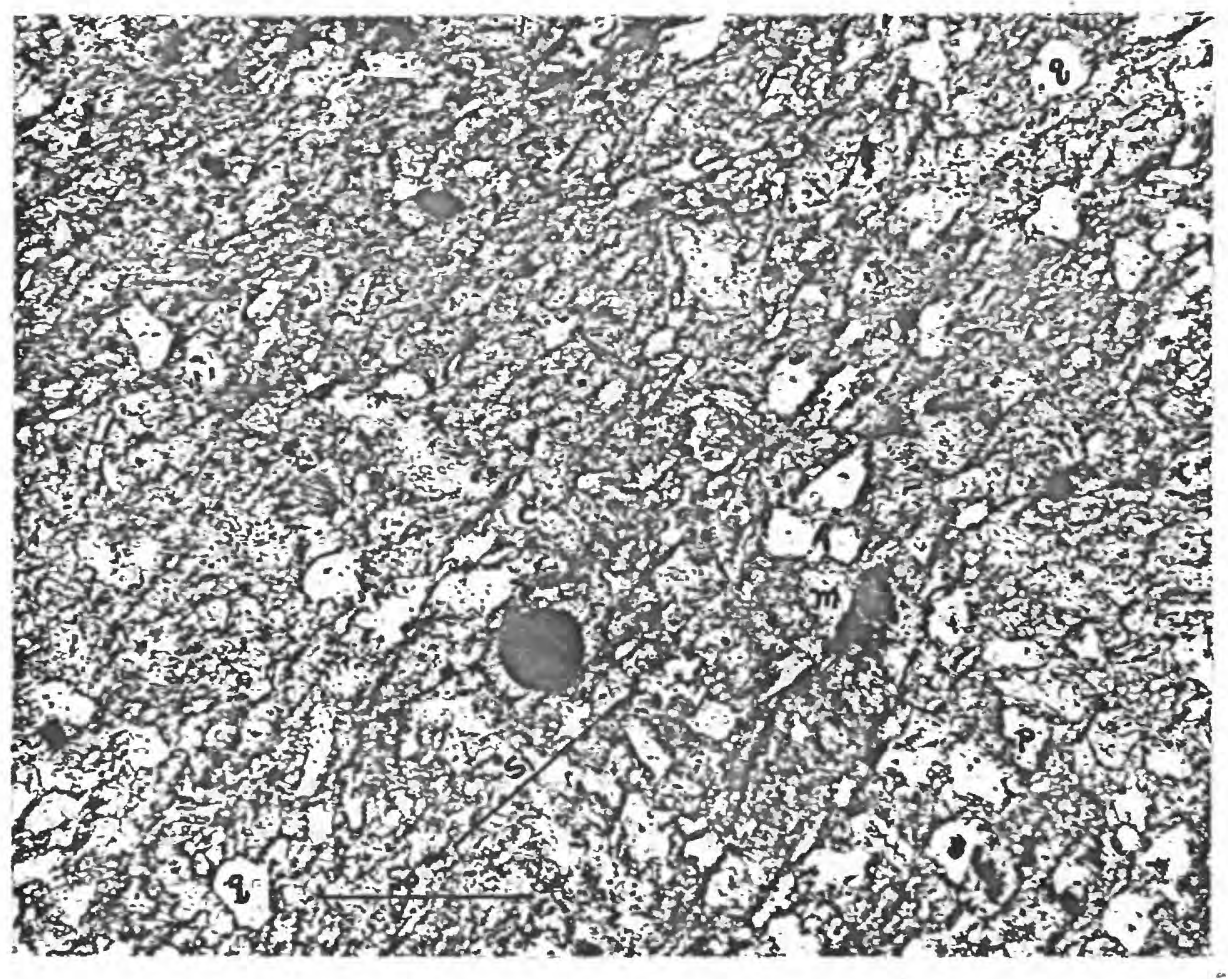

Figure 40. Photomicrograph (plane-polarized light, X 106) of calcareous shaly siltstone, Port Enen Shale, unit 3 of measured section 7, roadcut along U.S. Interstate 80 . Major minerals are angular to ragged quartz (q), calcite (c), muscovite (m), and lesser plagioclase (p), chlorite, pyrite (circular darik grain), and possibly very minor orthoclase. The grains lie in a nearly irresolvable finer matrix of quartz, muscovite, chlorite, calcite, and opaque minerals. Cleavage $\left(S_{I}\right)$ makes an angle of abou' $45^{\circ}$ to beding $\left(S_{0}\right)$. Note growth of quartz, chlorite, and muscovite parallel to cleavage on edges of pyrite grain. 


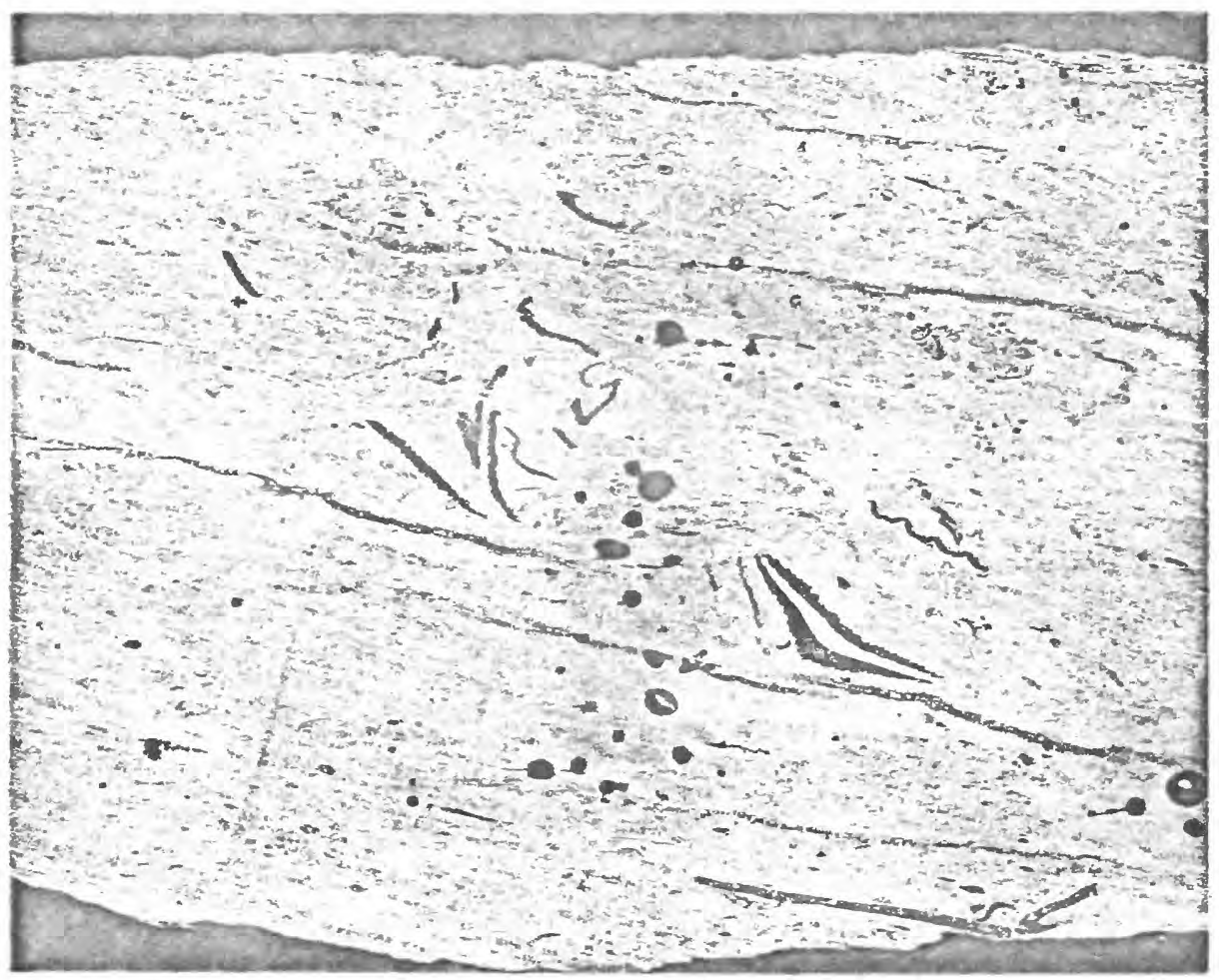

Figure 41. Calcareous siltstone to quartzose calcisiltite containing scattered skeletal debris of predominantly brachiopod shells. Bedding obliterated by burrowing. Port Ewen Shale, unit 5 of neasured section 7, roadcut along U.S. Interstate 80 . Southeastdipping cleavage trends to lower right. Negative print of acetate peel, X 2.5. Specimen stained with Alizarin Red S (calcite, mainly in shells, is dark gray to black in photo). 
Shriver and placed these rocks in the lower part of the Ridgeley Sandstone, having explained (Cleaves, 1938, p. 1109) that ".....the Shriver can not be established because of paleontological deficiencies .... Swartz and Swartz (19l1) used the namesOriskany Sandistone and Oriskany Shale for the corresponding units. Willard (1952) agreed and maintained that the Shriver was absent in eastern Pennsylvania. According to Swartz and Swartz (19L1), their Oriskany Shale is similar lithologically and has the same stratigraphic position as the Shriver, but the fossils are sparse and do not aid in correlation. Accepting the thesis that age does not make a formation, Epstein and Epstein (1967, 1969) retained the name Shriver in eastern Pennsylvania in the way Cleaves first described it, because it is an easily recognizable sequence. The name Shriver Chert was retained following the original usage of Swartz (1913). However, because of difficulty in mapping due to poor exposures of the contact between the Shriver and Ridgeley, and because of apparent vertical migration of the contact along strike, the Shriver and Ridgeley were mapped as a single unit in the Stroudsburg quadrangle, the Oriskany Group.

Many good exposures of the Oriskany, and especially the Ridgeley, are found in the quadrangle. A complete sequence crops out along U.S. Interstate 80 (fig. 35), along Brodhead Creek, I mile southeast of East Stroudsburg, and along Route 191 just north of its intersection with the Cherry Valley Road. The Oriskany Group ranges between 67 and 137 feet in thickness in the eastern half of the Stroudsburg quadrangle. The Riageley, along with the Esopus Formation, generally holds up the highest parts of Godfrey Ridge. 
Paleontologic and regional stratigraphic details of the Oriskany Group are given by Cleaves (1937, 1939) and Swartz and Swartz (1941).

Shriver Chert

Shriver Ridge, at Cumberland, Md., is the type locality of the Shriver Chert (Swartz, 1913). In the Stroudsburg quadrangle, the Shriver consists of interbedded chert, limestone, and sandstone. It is nearly 85 feet thick along U.S. Interstate 80 (measured section 7) and 54 feet thick on the southeast side of Brodhead Creek, 1 mile southeast of East Stroudsburg, a distance of only 1 mile from measured section 7. Two miles farther to the southwest, along Route 191 just north of its intersection with Chemy Valley Road, the Shriver thickens to about 102 feet at the expense of the Port Ewen because thin beds, nodules, and lenses of chert appear lower down in the section. The chert is dark gray and occurs as nodules, lenses, and irregular beds from about 2 inches to more than 5 feet thick with abundant spiriferid brachiopods (fig. 42). The limestone is medium-dark gray, light-to medium-gray- and light-tannish-gray weathering, fine grained, siliceous, and fossiliferous. It occurs in nodules, lenses, and irregular beds about 2 inches to more than 10 feet thick. It is locally extensively burrowed (fig. 43). The sandstone is medium to light gray, calcareous, medium to very coarse grained and conglomeratic (pebbles as much as $\frac{1}{2}$ inch long). It occurs as beds 1 inch to 2 feet thick (fig. 42). The sandstone is moderately to poorly sorted orthoquartzite (fig. 44 ). Occasional chert pebbles suggest that the chert in the Shriver formed during early diagenesis and was later reworked to form pebbles. Preserved bedding laminae in the chert and replacement of fossils by 


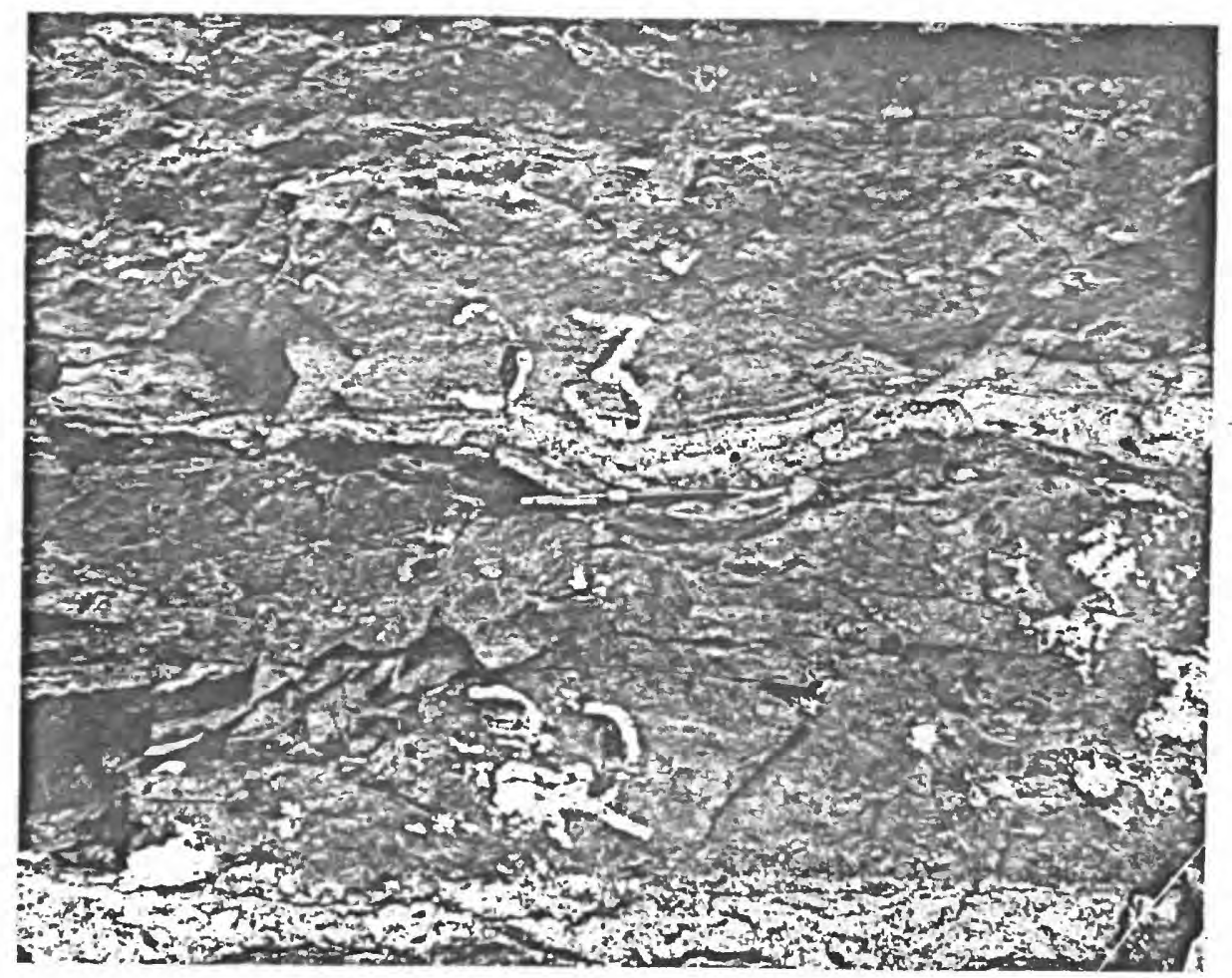

Fifure 42. Shriver Chert of Oriskany Group. Lrminated to partly crossbedded coarse-grained calcareous sandstone (base of unit 16, measured section 7) overlain by dark-gray chert with abundant spiriferid brachiopods that are made of calcite and which upon weathering leaves numerous molds. The sandstone is channeled into the underlying chert. 


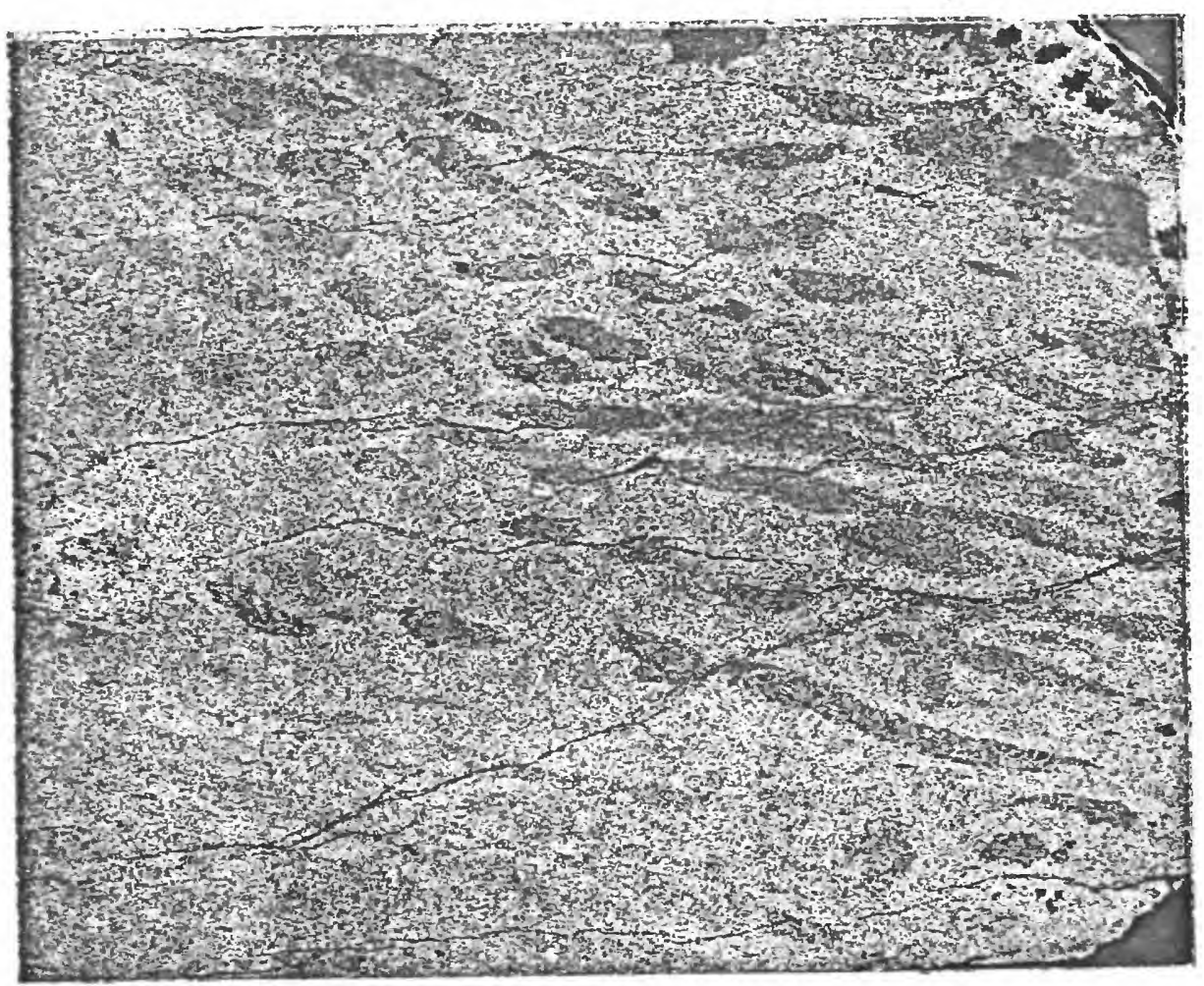

Figure 43. Burrowed calcisiltite, Shriver Chert of Oriskany Group. Unit 8 of measured section 7. Specimen stained with Alizarin Red S (darker grains are calcite). Negative print of acetate peel taken about parallel to bedding, $X 2.6$. 


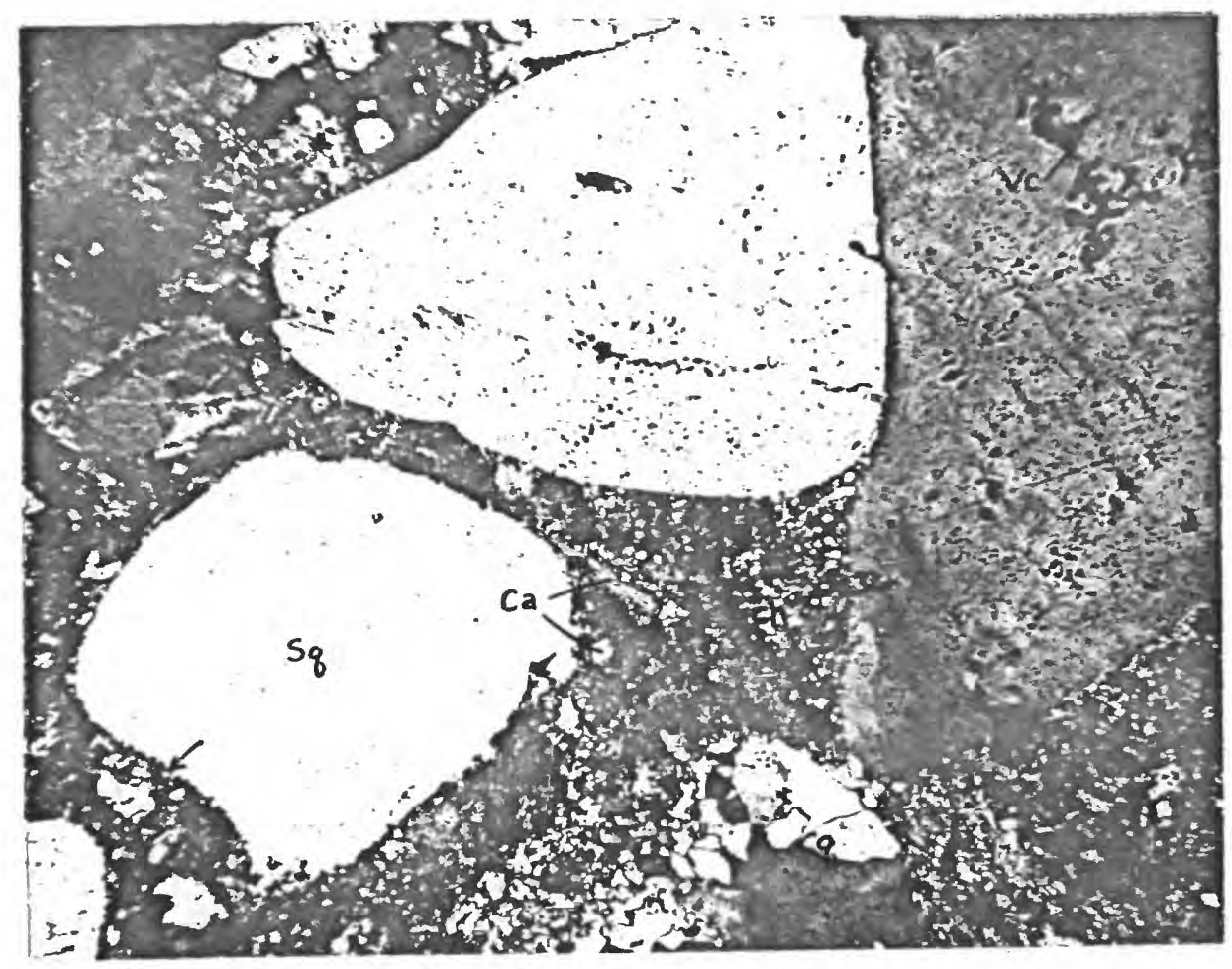

Figure 44. Photomicrograph (crossed polarizers, X 43) of very coarse-grained orthoquartzite in the Shriver Chert of the Oriskany Group, unit 19 of measured section 7. Quartz grains (79 percent) are rounded to subrounded, single (sq) to composite (cq) with undulose to strongly undulose extinction and minor overgrowths. The quartz is cemented by chert (ch, 16 percent) and calcite (ca, 5 percent). Minor muscovite ( $\angle I$ percent) is present in the groundrass. Some quartz grains have vermicular chlorite inclusions (vc). The borders of some quartz grains are diffuse where replaced by chert (arrow). 
chert also argue for a penecontemporaneous diagenetic origin.

Cleaves (1939) believed the Shriver was not present in eastern Pennsylvania and maintained that the Ridgeley rests directly on the Helderbere (Port Ewen). This unconformity was accepted by Cooper and others (1942) and Jones and Cate (1957). Its regional significance was shown by Swartz (1939) and Swartz and Swartz (1941) who demonstrated that many units were truncated by the pre-Oriskany unconformity in eastern Pennsylvania. Swartz (1939) also suggested the presence of a positive area near Harrisburg, $\mathrm{Pa}$., the Auburn promontory, to account for depositional thinning or nondeposition of many of the Keyser and Helderberg units. Willard (1941), expanding on Ulrich (1911), noted that many Ordovician through Devonian units, including the Oriskany, thin or pinch out by onlap onto the Harrisburg axis, as he called the positive area. However, Willard (1952) questioned if the re was any pre-Oriskany lost interval on Brodhead Creek in the Stroudsburg quadrangle. The Port Ewen-Oriskany boundary is transitional in the quacirangle (Epstein and others, 1967; this report), reflecting a gradual regression. Only minor diastemic breaks are indicated.

\section{Ridgeley Sandstone}

The Ridgeley was proposed for fossiliferous sandstones in Allegany County, Md., and adjacent West Virginia. It was named for Ridgeley, W. Va.

In the. easternmost part of Godfrey Ridge, the Ridgeley is $\Psi_{4}$ to 16 feet thick, but along Rout 191 on the south side of the ridge it thickens to 33 feet. It consists of medium- to light-gray, brownishorange- to oxange-gray-weathering, fine- to very coarse grained, evenly 
to unevenly bezied, planar-bedded to crossbedded calcareous sandsione (presumably crt:-oquartzites as in the underlying Shriver) and lesser quartz-pebble conglcserate with pebbles as much as 0.5 inch long. The Ridgeley also contains a fer thin beds and lenses of medium-gray siltstone, arensceous and argillaceous fine-grained limestone, and dark-gray chert. The lower contact is abrupt and placed at the base of the predcitisntly sandstone interval.

\section{Post-Oriskany and Pre-Hamilton Rocks}

Rogers (1553) terigd the sequence of shale, siltstone, and cherty limestone overlying the Oriskany the Post-Meridian, which White (1882) and Prosser (152) subdivicied into the Caudi-galli Grit below and Corniferous li-estora above. Kindle (1912) replaced the name Corniferous with the Onondaga Limestone and the Caudi-galli with the Esopus Snaje. Neither White (1882) nor Willard (1936a, 1939) recognized the Schoharie in eastern Pennsylvania. Hillard (1936a) believed these rocks to be Middle Devonian in age and placed them in the Onondaza Fimation of the Hamilton Group. He subdivided the Onondaga into two meriers, the Esopus for the lower shaly part and "upper cherty limestone" for the upper part in Monroe County, Pa. Willard (1939) later excluded these rocks from the Hamilton Group and raised the Oncadaga to group rank with the newly proposed Buttermilk Falls Linestcre overlfing the Esopus Shale. The Schoharie Formation and Esopus Sriale of Early Devonian age were carried into northeastern Pennsylvania $b_{i}$ Cooper and others (1942), apparently based on the work of Goldring ad Floner (1942). Cooper and others show these overlain by the Butter=ilk Falls Iinestone of Early or Middle Devonian age. The 
Buttermilk Falls and Esopus are considered part of the Onondaga Formation on the state map of Pennsylvania (Gray and others, 1960). The Schoharie was first recognized in the Stroudsburg area by Herpers (1950) who called it the "X-beds," and later by Trexler (1953), Johnson (1957, 1959), and Johnson and Southard (1962). Oliver (1956, 1962) equated the Buttermilk Falls with parts of the Onondaga Limestone of New York and concluded that both are Middle Devonian in age. The latest correlations (0liver and others, 1969) place the Buttermilk Falls in the Middle Devonian and the Esopus and Schoharie in the Lower Devonian. Faunal lists for the Esopus through Buttermilk Falls are given by Prosser (1892), Kindle (1912), and Willard (1936a, 1938, 1939).

In the Stroudsburg quadrangle, the rocks between the Oriskany and Hamilton Groups include, from the base upward, the Esopus Formation, the Schoharie Formation, and the Buttermilk Falls Limestone. The Buttermilk Falls is divided into three new mappable members. The distribution and stratigraphic relations of the se rocks betreen Delaware and Lehigh Rivers in eastern Pennsylvania are given by Epstein and Epstein (1967, 1969).

\section{Esopus Formation}

Darton (1894) named the Esopus Shale for exposures along Esopus Creek, near Esopus, N. Y. In the Stroudsburg area, White (1882) measured 250 feet of his Caudi-galli Grit and Willard (1936a, 1938) reported more than 250 feet of the Esopus Shale and Iater (1939) revised the figure to more than 300 feet. In their measurements, both Willard and ihite included rocks herein assigned to the Schoharie 
Formation. Johnson (1957) and Johnson and Southard (1962) believed the Esopus to be more than 200 feet thick in the Stroudsburg area. The Esopus is 181 feet thick in bluffs north of the ErieLackawanna Railroad, I mile east of East Siroudsburg. It is a medium- to dark-gray, medium-gray-weathering, shaly to finely arenaceous siltstone and lesser silty shale and minor calcareous siltstone. Cleavage is very well developed, masking the sedimentary features. The rock is laminated except where it is burrowed. The trace fossil Taonurus is common, as it is in the basal Schoharie (figs. 46, 58). Brachiopoàs are uncommon. Moderate-yellowish-brown to dark-yellowish-orange staining is distinctive. For practical separation from the overlying Schoharie into which it grades, the Esopus is decidedly less calcareous or noncalcareous, it has better developed cleavage, the iron staining is characteristic, and, when hit with a harmer, it emits a dull "thud" as compared to the firmer "ring" of the more massive Schoharie.

In thin section, the Esopus is composed mainly of shaly graywacke siltstone and consists of medium-to coarse-silt-sized quartz (about 40-50 percent), muscovite, and chlorite (15-30 percent), calcite (probably averaging <3 percent), plagioclase, chert, and angular to rounded tournaline and zircon (rare) in a fine-silt to clay matrix probably mostly of quartz, muscovite, and chlorite. Opaque minerals, including pyrite and leucoxene, comprise about I percent. The quartz Is ragged and replaced with minor muscovite and chlorite in pressureshadow areas of cleavage. Many of the muscovite, chlorite, and some quartz grains are oriented parallel to cleavage, apparently dragged to 
this position and crushed to smaller sizes.

The Esopus holds up some of the highest parts of Godfrey iidge:

Good exposures are numerous, as those along the abandoned rail road grade west of Minisink Hills, in and near Foxtown Cap, on the north slope of Codfrey Ridge along U.S. 611, and along the road east of Pine Grove Lake north of Stormville.

The base of the Esopus is in sharp contact with the underlying Ridgeley Sandstone and is reputed to be unconformable (billard, 1936a; Cleaves, 1937; Cooper and others, 1942; Jones and Cate, 1957). This interpretation is supported by the faunal break, abrupt lithic changes, and inferred different environinents of deposition to be discussed later.

\section{Schoharie Formation}

Vanuxem (1840) named the Schoharie for exposures in Schoharie County, N. Y. At Buttermilk Falls in the East Stroudsburg quadrangle (pI. III), Herpers (1950) placed 72 feet of rock in his "X-beds," including calcareous siltstones in his "Esopus senso stricto," which are part of the Schoharie as identified by Johnson (1957), who measured 102 feet of Schoharie at the same localj.ty. The base of the Schoharie, as recognized by Johnson (1957) and Johnson and Southard (1962), is placed at the lowest prominent calcareous siltstones or nudstones overlying the Esopus. Accepting this contact, which also coincides with the base of the lavest massive siltstone, 103 feet of Schoharie was measured near Butternilk Falls (measured section 8, fig. 45). The Schoharie in the Stroudsburg area is predominantly a medium-gray to grayish-black, thin-bedded to massive and laminated, fairly evenly 


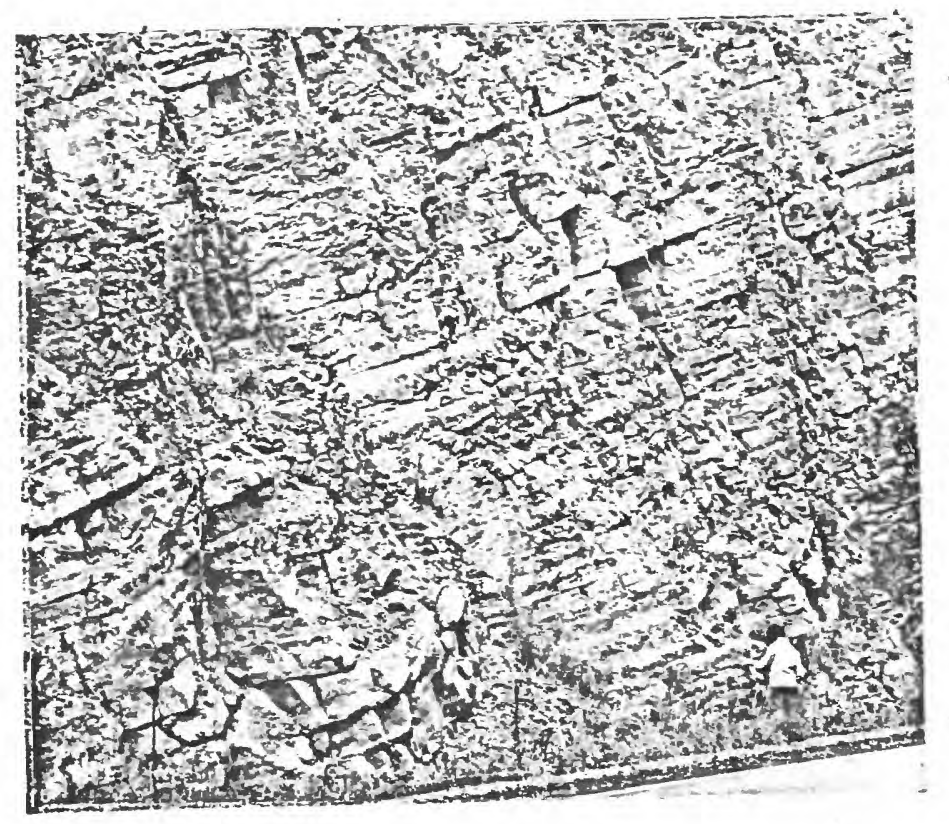

Figure 45. Moderately evenly bedded siltstones in the Schoharie Formation in roadcut along U.S. Route 209 near Buttermilk Falls, East Stroudsburg quadrangle (see pl. III, measured section 8 ). Lighter weathering beds are more calcareous. 
bedies, calcareous siltstone with lesser fine-grained sandy biltstone. Beds $s=2$ is much 8.6 feet thick. Dark-gray chert which weathers light gro: Is scattered throughout as rounded and frregular nodules and lenses ss much as 2 Inches thick. The chert is more abundant towards the tz2. Burrow wottling is comon. Horizontal burrows (Taonurus) are abunient in the lower half (f1g. 46), and vertical burrows are wore cocon in the upper half. Brachiopods are common. The base of the Sorzation, according to Johnson (1957), is marked by a zone of Leptcacelia acutiplicata and is typical of his Carlisle Center facies. The Siloharie is transitional into the Esopus and the base Iocally is placel within a 10 to 20 foot interval with difficulty.

In thin section ( $\mathrm{fig} .47$ ), calcite as microspar and as sparry calcite rhombs comprises 40 to 60 percent of most of the rock in the Schobarie. Quartz (35-55 percent) is etched and generally occurs as ingle grains, but a few composite grains and grains of chert were noted. Muscovite and chlorite make up less that 5 percent of the rock. Rogioclase feldspar ( $<I$ percent) and rare tourmaline, zircon, and opeque minerals, including pyrite and leucoxene, are accessory alnerals.

The Schoharie is fairly well exposed in Godfrey Ridge. It searally holds up high parts of the ridge. Besides the locality sear Buttermilt Falls, good exposures are found in an abandoned quarry, 0.9 aile west of Minisink Hills, $\mathrm{Pa} .$, along the abandoned railroad bade Just west of Minisink Hills, along U.S. 611 where it crosses Portown Hill in the railroad cut nearly 1 wile south of the East 8 troudiburg post office (measured section 9), and on the north Blope 


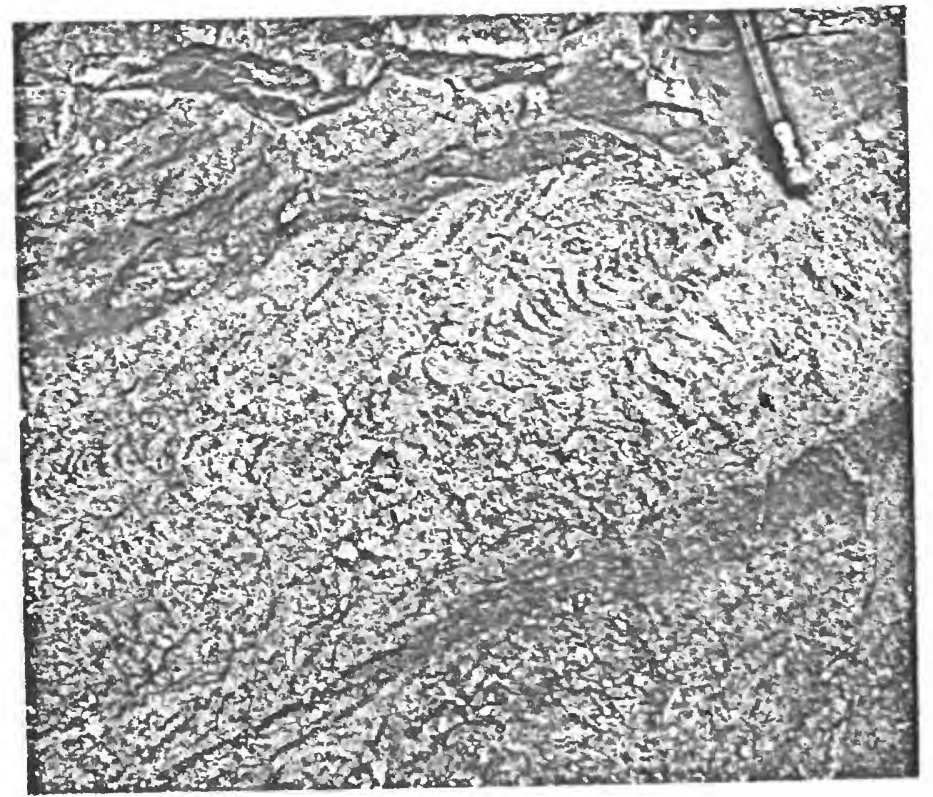

Figure 46. Taonurus, believed to be a horizontal burrow, in the lower half of the Schoharie Formation, in roadcut along U.S. 209 near Buttermilk Falls, Pa., East Strouảsburg quadrangle. 


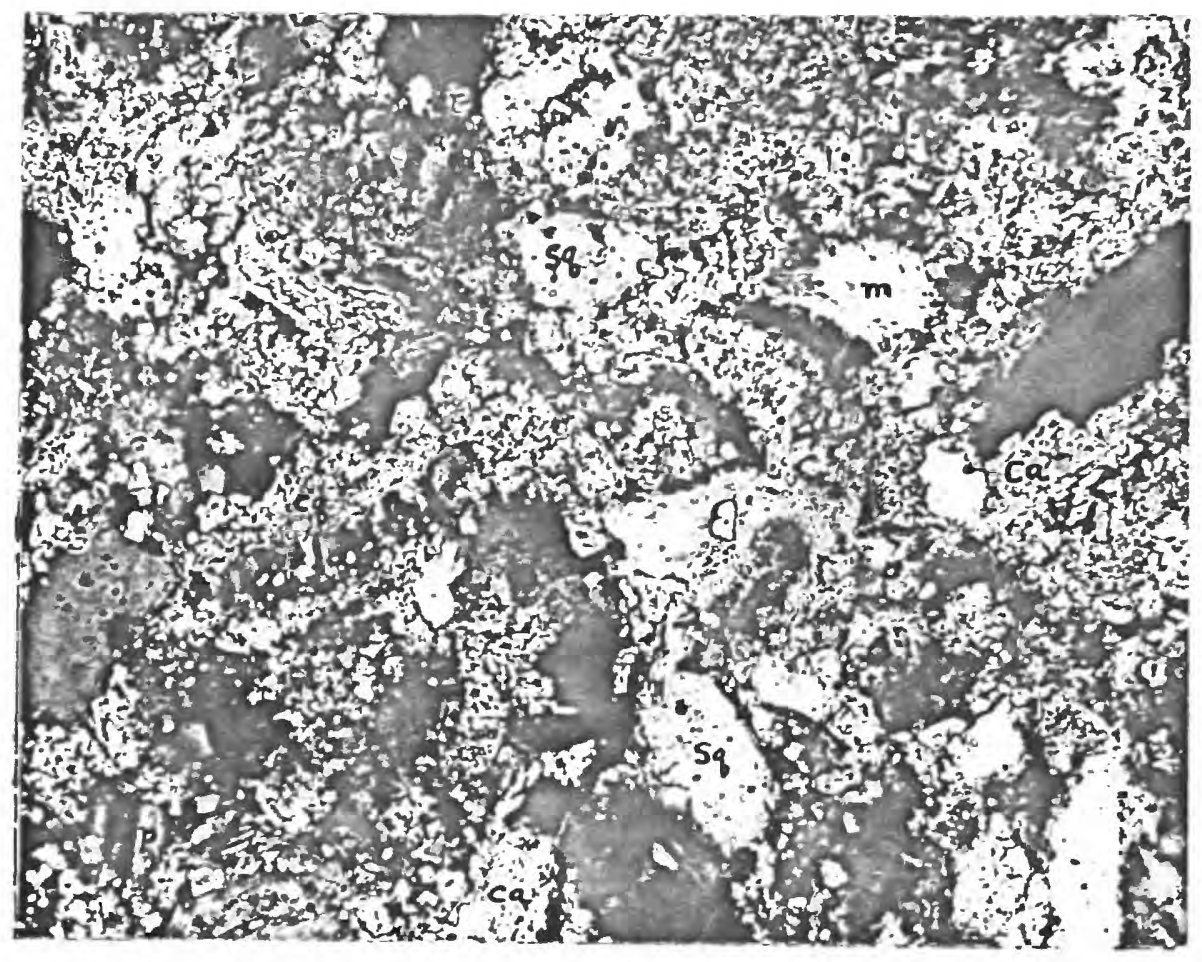

Figure 47. Photomicrograph (crossed polarizers, X 277) of very coarse grained quartzose calcisiltite or calcareous siltstone in the Schoharie Formation, 50 feet below the contact with the Buttermilk Palls Livestone. From rosicut along U.S. 209 near Buttermilk Falls, Bast Stroudsburg quadrangle, unit 4 of measured section 9 . The rock contains about 50 percent calcite (ca) which occurs as microspar and recrystallized rhombs; etched, predominantly simple quartz (sq, about 45 percent) with a few composite grains (cq), and minor muscovite (m), chlorite, and plagioclase feldspar (p). 
of Goafrey Ridge north of Siorwilie.

\section{Buttermilk Falls Iimestone}

The type locality of tie Buttermilk Falls Linestone is at Buttermilk Falls on Marshsil Creek in the $E_{\text {ast }}$ Stroudsburg quadrangle. Willard (1939) named the wit and belleved it to be about 200 peet thick. At the type locality (measured section 8), only the lower 25 feet are exposed. Elsewtere, as in the railroad cut of the ErieLackawanna RaIIroad, I wi: south of the East Stroudsburg post office, the Butterwilk Falls is $\tilde{C}^{-} 2$ feet thich and consists of three wappable members--a medial calcarezus silty shale separating two cherty limestones. These members are herein named, in ascending order, the Foxtown, McMichael, and Stroudsburg Members.

\section{Foxtorn Mernber}

The type section of the Foxtown and other members of the Buttermilk Falls Limestone is in the railroad cut of the Erle-Lackawanna Ra1lroad, nearly 1 mile south of the East Stroudsburg post offlce (measured section 9). The name is taken from Foxtown Hill on Godfrey Ridge where the member is exposed in nearly vertical beds along U.S. 611 .

The Foxtorn consists of wavy bedded and lenticular, medium-gray to medium-dark-gray, light-sray- to medium-light-gray-weathering, cherty Iirestone in beds 1 incs to 2 feet thick (rig. 48). Grain size is Benerally fine ( $\mathrm{fig} .40$ ), but very coarse grains are not uncomon. The Iimestones are inte-bedded with medlum-dark-gray, calcareous, evenly bedded shale and siltstone in beds 1 inch to 1 foot thick, and contain dark-gray to graylsh-black chert. The chert in the lower half occurs as irregular noines $\frac{1}{2}$ to 6 inches in diaweter. Chert is more 


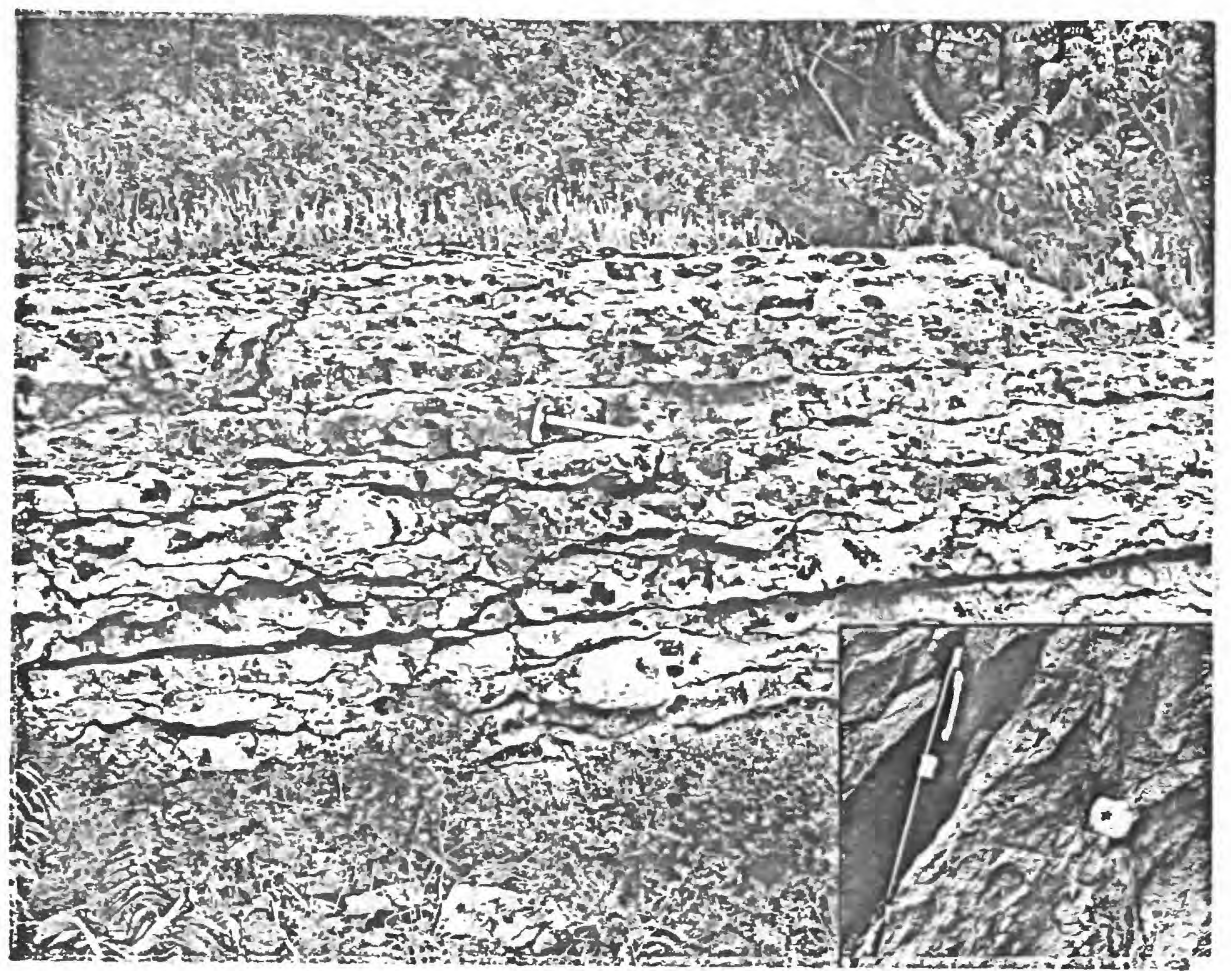

Fisure 48. Irregularly bedded cherty limestone in the upper half of the Foxtown Nerber of the Buttermilk Falls Limestone, in rosdcut on Brown Street, 5,000 feet northeast of the hospital in East Stroudsburg. Inset shows 1-inch dismeter crinoid columnals from the lower part of the Foxtwon liember at the type section on the ErieLaclswanna Railroad, south of East Stroudsburg, $\mathrm{Pa}$. 


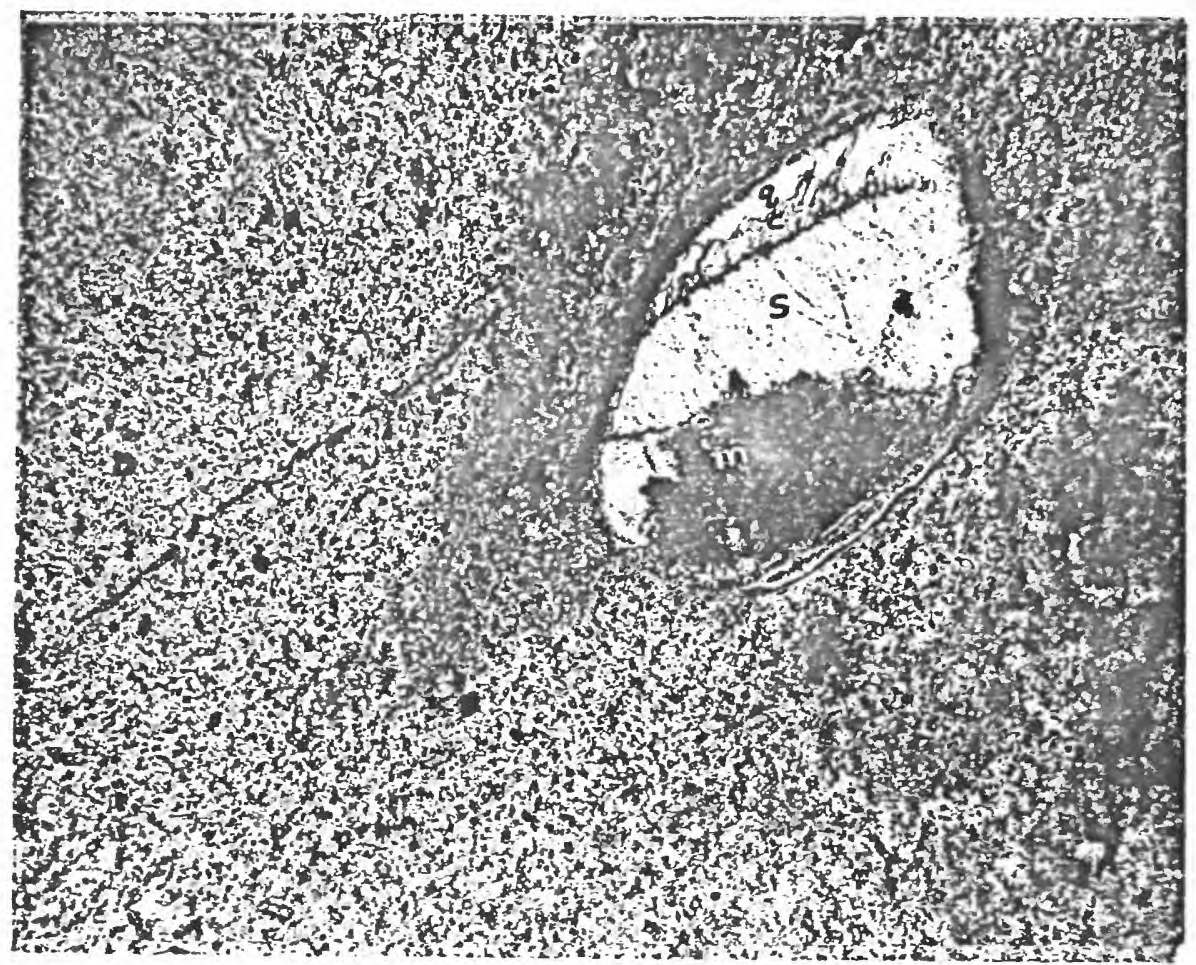

Figure 49. Photonicrograph (plane-polarized Iight, X 42) of cherty biowicrite (Iight areas) and blowicrite (dark areas) with ostracode partly filled with micrite $(\mathrm{m})$, a probable geopetal structure, and sparry calcite (s). Shell is partly filled with quartz $(q)$, and calcite $(c)$, alligied parallel to rock cleavage. Foxtown Nemior of Buttermilk Falls Limestone, near Buttermilk Palls, East Stroudsburg quadrangle, unit 5 of measwred section 8 . Bowe other samples of the Foxtown are biomicrudites, partly neocrystallized to microspar and pseudospar. 
abundant in the upper half where 1t makes up wore then 50 percent of the unit and contains interbeds of calcareous argillite 1 to 2 inches thick and Ilmestone pods 2 to 6 inches in dismeter. The chert contsins varying amounts of calcite and mica (f1g. 49).

Large crinola columals ( $f$ ig. 48), as much as 1 Inch in diameter, are consplcuous in the lower half of the Foxtom Member. W. A. Oliver (1962, and written cotwun., 1962) traced large crinoid columals, marking the base of his Eagecliff Hember at the bottow of the Ononoaga Limestone, from Onondaga, R.Y., to Port Jerv1s, K.Y. He saw a similar crinoid marker bed at the bottom of, the Buttermilk Falls Ilmestone near Stroudsburg and belives that the Buttermilk Falls of eastern Pennsylvania is the equivalent of the Onondaga of southeastern New York. Although stratigrephic relations have not been vorked out between Monroe County, Pa., and southeast liew York, the facies changes alone are sufficient to justify the new names in the Stroudsburg quadrangle (W. A. Oliver, written commu., 1963).

At the type section, the base of the Foxtown Meaber is marked by a 1-foot-thick, medium-gray, medium- to very coarse grained limestone in abrupt contact with the underlying Schoharie Formation. In the western part of the Stroudsburg quadrangle, the boundary between the Foxtown and Schoharie is transitional through about 6 feet of cherty calcareous siltstone and silty lirestone.

The Foxtown Hember is 82 feet thick at the type section. In the abandoned quarry south of U.S. Interstate 80 and 1,200 feet west of where the highway crosses Brodhead Creek (Slater-Canfield quarry, according to Johnson, 1957, who assigned the beds to the Schoharie 
Formation), the Foxtowin is 80 fect thick and the lover 45 fect

contains the large crinold colurnals.

The Foxtorn Member is fosstliferous. Brachiopods are comion and a large silfcifled ostracode faunule was recovered by dissolving the rock In dilute acetic acid. The following ostracodes were identified by J. M. Berdan and A. G. Epstein, U.S. Geological Survey:

Acathoscaoha navicula (UIrich)

Aechmina sp.

Arophizona $\mathrm{kp}$.

Bajrdites? sp.

Beecherclla sp. cr. B. carinata Ulrich

Bufina $\mathrm{sp}$.

Camdenicua

Bollinelia sp.

Kirkbyelta (Berdanel1a) sp. cf. K. (‥) unicornis

(Coryell and kalkin)

K1rkbyella sp.

Menoelaina sp.

New genus afr. Pachyaiomella thl1psuroldea Swain

Parebolbina $8 \mathrm{p}$.

Ranapelitis trileterelis Swartz and Swain

Ranapeltio sp.cf. R. unicarinata

Ranapeitis sp.

Richina? sp.

Ruãarina sp.

Strepulites bifurcatus (Bassler)

Tricorning? $\mathrm{sp}$.

Tubultbalrdia sp.

- Tubulibeiraia? sp.

Ulrichia pluripuncta Swartz and Swain (Coryell and MaIkin)

According to Berdan (written coman., 1963), these have affinities

with forms described from the Hamilton Group and Onondaga Linestone.

Thus, it is probable that the collection represents beds of Onondaga

age (Middle Devonian) rather than of Schoharie age (Early Devontan).

The Foxtown Nember generally forms slight topographic bigha on the north slope of Godfrey Ridge. In addition to the localities mentioned, bood exposures are found at the foot of Godfrey Ridge along the 
junction of U.S. 511 and State Route 191, and at the west edge of the Stroudsbure ¿uadrangle near McMlchael Creek.

\section{McMichael Kémb}

The member is named for Kcklchael Creek north of Godfrey Ridge. At the type section, along the Erie-Iackaranna Rallroad ( $f$ ig. 50), it is 41 feet thick a-3 at the Slater-Canfield quarry it is 42 feet thick. It consists of srenly bedded to lenticular, wediun-gray to medium-darkgray, medium-graf weathering, calcareous, partly silty, fossiliferous shale or argillite in beda 2 inches to 1 foot thick, and interbedded medium-gray, fi-e-grained (probably biomicrite and blomicrudite) fossiliferous lizestone in beds, lenses, and nodules 1 to 3 inches thick. Fossils are abundant and include crinoid, trilobite, bryozoan, and kzachlopod debrls and ostracodes. Sll1clfied ostracodes were recovered et the type section and were identified by $J$. M. Berdan and A. G. Epstein, U.S. Geological Survey. They are of probable Onondaga age ex: include:

Aesinins sp.

At-izona sp. cr. A. asceta Kesling and Copeland

Bai-jiocypris? sp.

Bqsidites? sp.

Boilia disceratina Swartz and Swain

B. Jlanojugosa Swartz and Swain

Bưfina 8p.

Eu=-1yphella? sp.

Eu-ioedenella? sp.

Fstulella dicarinella Swartz and Swain

P. Pavulosa (Jones)

É:inella sp. aff. H. antespinosa (Ulrich)

KI=-byella (Eerdanelīa) $5 p \cdot c f . \underline{K}$. (B..) unicornis (Coryell and Malkin)

Pesiydomella sp.

Pe-abolbina parvinoda Swartz and Swain

PE-ibolbina $\mathrm{sp.}$ Fi=apeltis trilateralis Swartz and Swain 


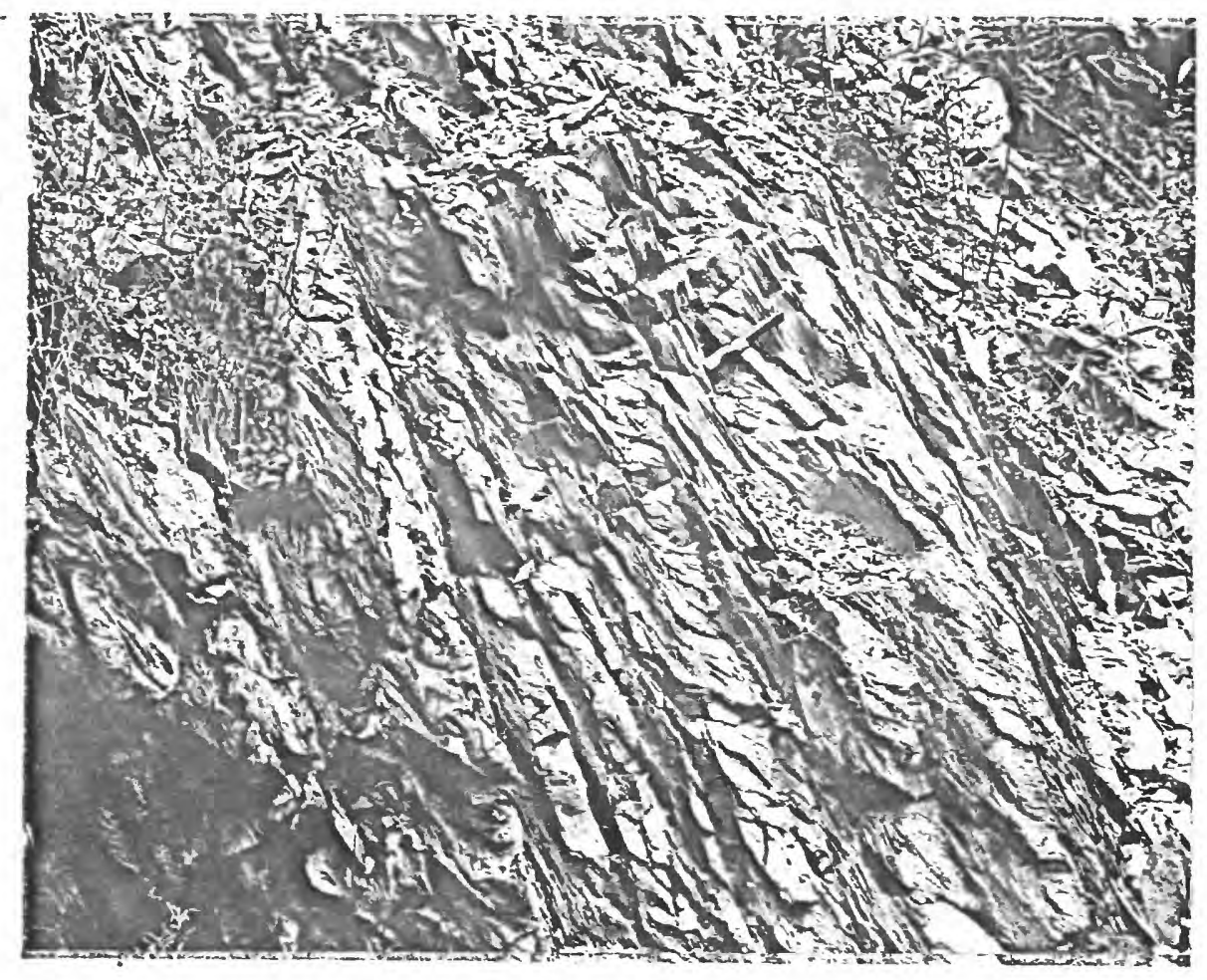

Figure 50. Evenly bedded and lenticular limestone (11ght) and calcareous argillite (dark) in the KcMichael Hember of the Butterwilk Falls Liwestone at the type locality along the Erle-Lackavanna Railroad, nearly 1 mile south of the East Stroudsburg post office. The beds are overturned to the southeast (to right) and dip wore steeply than the prowinent cleavage in the argillite. liote refraction of the cleavage in the limestone. 
Reversocypris? $\mathrm{sp.}$

Rhonsionelius sp.

Ricling sp.

Rishona? $\mathrm{sp}$.

Rudiserina $\mathrm{gp.}$

Strepulites bifurcetus (Bassler)

Tricornina sp.?

Tubulibairaia sp.

Tubulibalraia? sp.

Uirichie elongata Swartz and Swain

?Ulrlchia pluripuncta Swartz and Swain

The McMichael Member is poorly exposed except for the localities

mentioned. It forms a topographic sadje between the cherty limestones above and below. The lower boundery is gradational.

\section{Stroudsburs Merber}

This nember is named for Stroudsburg, Pa., where good exposures are seen along U.S. Interstate 80 ( 1 ig. 79 ). At the Slater-Canfield quarry, the lower 15 feet are exposed and at the type section (fIg. 5I) 149 feet are exposed. The Stroudsburg consists of irregularly bedded, medium-gray to medlum-dark-gray, light-gray to medium-1ight-grayweathering, fossiliferous, fine- to medium-grained, locally argillaceas IInestone in beds and lenses 1 inch to 1 foot thick, and dark-Bray to grayish-black chert in irregular beds, lenses, and pods 0.25 inch to 1 foot thick. The upper 15 feet at the type section and also to the Bouth of stroudsburg contain several beds, 3 to 6 inches thick, of medlum-gray to medlum-Ilght-gray, light-gray-weathering, medium- to very coarse grained limestone (probably biosparrudite) with abundant brachiopod, coral, and crinoid debris and some conodonts. These conodonts, as well as some ostracodes from the rest of the member, have ngthe yet been Identified. The McMichael and Stroudsburg Metbers have a eradational boundary. The Stroudsburg Member is generally exposed 
111

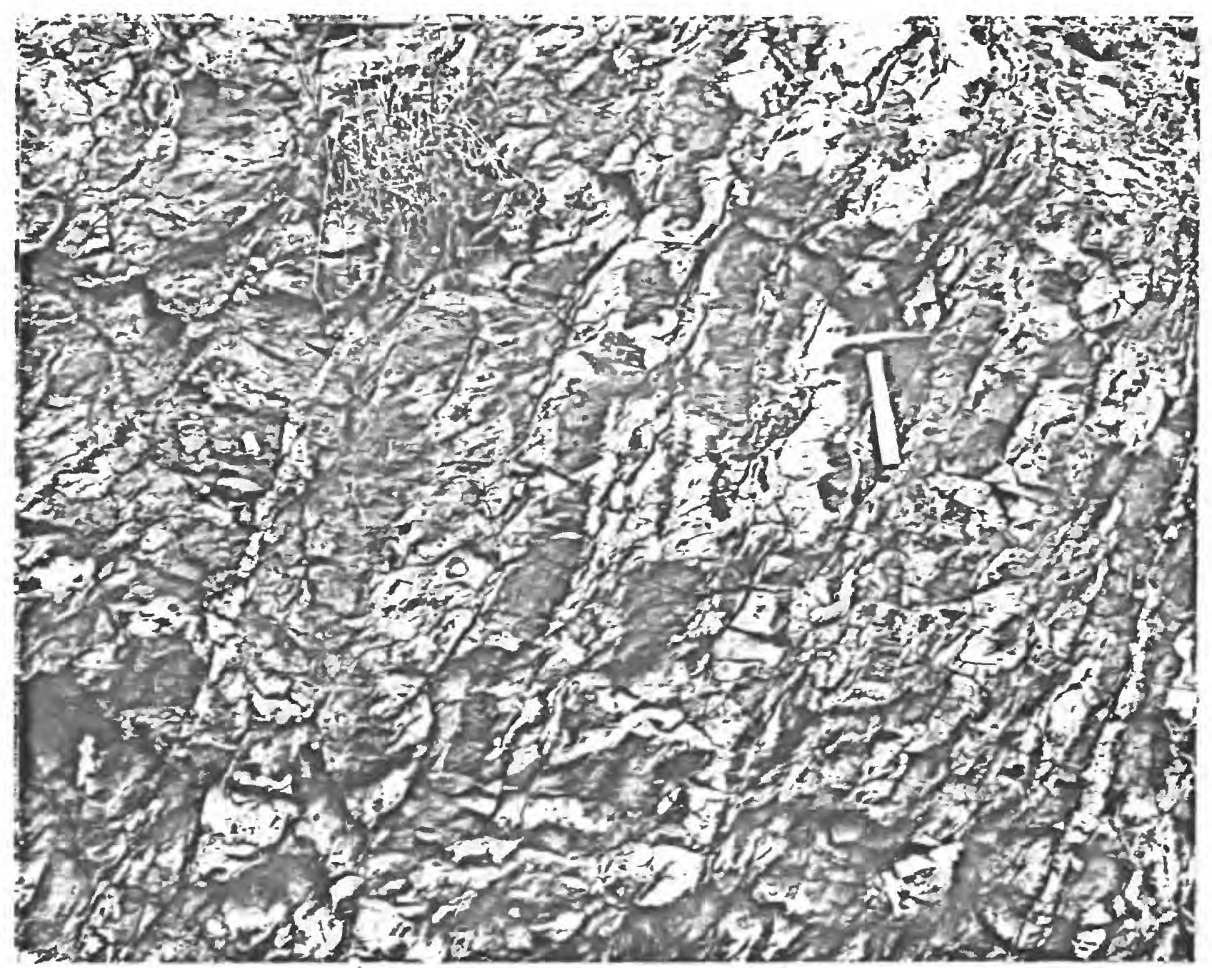

Flgure 51. Unevenly but distinctly bedded chert (dark) and Ilmestone (light) in the Stroudsburg Nerber of the Butterwilk Falls Limestone at the type section elong the Erie-Lackawanna Rallrosd south of East Stroudsburg. Beds are overturned to the southeast (to left). Note poorly developed cleavage dipping gently to the southeast. 
in several small hills that rise above the valleys of McMichesl and Brodhead Creeks.

The Tloga Bentonite that may be present at the top of the Buttermilk Falls (see Oliver and others, 1969) has not been seen in the Stroudsburg quadrangle, although it is present 25 miles to the southwest in the Iehighton quadrangle. If present, and presurably it is, It is in the covered interval between the Buttermilk Falls and the exposed Marcellus Formation.

\section{Hamilton Group}

The predominantly cherty limestones of the Butterwilk Falls Lirestone are succeeded by a thick sequence of predominantly fine clastic rocks, to which Rogers (1858) applied the term "Cadent Serles." White (1882) divided these rocks into the Eamilton Sandstones above and Marcellus Shale or Lower Hemilton below, correlating them with the Eamilton of New York. The Harilton Group was narued by Venuxen (1840) for exposures at West Hamilton, N.Y., and later the Hamilton wes redefined by Vanuxem (1842) to Include rocks from the base of the Tully to the top of the Karcellus. Clarke (1885) redefined the Hamilton to Include the Marcellus in New York. In Pennsylvania, W1llard and Cleaves (1933) recognized, In descending order, the Noscow, Ludlowvllle, Skaneateles, and Marcellus faclea. Later, W1llard (1935, 1937, 1938, 1939) noted that the rocks above the Marcellus could not be lithically oubdivided in eastern Pennsylvania and named them the Mahantango Formation. W1llerd (1936b) recognized a blostrome within the Mahantango, which he correlated with the Centerfield Iimestone of 
York. The basal 150 feet of the Marcellus in the Stroudsburg area is made up of calcareous shaly siltstone and shale which have been placed in the Marcellus or in the Buttermilk Falls by varlous workers. As defined below, these beds are assigned, as members, to the Stony Hollow of Cooper (1941) and Union Springs of Cooper (1930) and Included in the Marcellus Shale. Overlying these rocks is the Brodhead Creek Member, first suggested by Hillard (1938). At the top of the Hamilton Group in the Stroudsburg area is the Mahantango Formation containing the Centerfield biostrome.

\section{Marcellus Shale}

The name Marcellus was given to some rocks exposed near Karcellus, N.Y., by Hall (1839). White (1882) recognized 800 feet of the Marcellus in the Delaware Valley of eastern Pennsylvania. Willard (1938) believed the thickness to be between 800 and 900 feet, and later (Willard, 1939) gave a maximum thickness of 880 feet. In the Stroudsburg quadrangle, the Marcellus is poorly exposed or covered in many places by drift; it could be as much as 1,100 feet thick.

Stony Hollot and Union Springs Members, undifferentiated

White (1882) recognized 300 feet of gray shale at the botton of his Marcellus in the Stroudsburg area. W1llard (1938) belleved that the basal Marcellus is transitional into the Buttermilk Falls Limestone and named these transitional beds the Shamokin Black Shale, but later (Willard, 1939) maintained that these shaly trangitional hads were in the Butternilk Fallo. Alvord (oral comman. to Oliver, 1961, in 01lver, 1962) belleved that about 50 feet of interbedded 
and Iinestone is an upper meraber of the Buttermilk Falls Limestone in the Bushkill quadrangle. Oliver (1964) later placed these beds within the lower part of the Marcellus, correlating them with the Stony Hollow Sandstone of Cooper (1941) of New York, which Cooper (in Cooper and others, 1942) traced to Echo Lake, Pa., about 9 miles northeast of Stroudsburg in the Bushkill quadrangle (fig. 1). The Stony Hollow at Echo Lake kiss described as a calcareous sandstone, but in actuality it is predominantly a calcareous siltstone and shale, as it is near Stroudsburg. According to Cooper and others (1942), the Bakoven Shale underlies the Stony Hollon, but the neme Bakoven was dropped in favor of the Union Springs Stale (originally named by Cooper, 1930) in southeast New York (Rickard, 1964). Both the Stony Hollow and UnIon Springs are members of the Marcellus Formation in New York. North of Lehigh Gap, along the northeast extension of the Penneglvania Turnpike, in the Lehighton quadrangle (fig. 1), Willard (1957) recognized 15-20 feet of black shale at the base of the Harcellus that he belleved resembled the Union Springs of New York. The black shale along the Turnpike, which I measured to be 29 feet thick, is orerlain by 42 feet of interbedied calcarecus shale and shaly limestone, which I place in the Stony Hollow. These members can be traced in very scattered exposines to the Stroudsburg area.

Thus, the lower beds of the Marcellus in easternmost Penniglvania are placed in the Stony Hollow and Union Springs as members. Based on these identifications (written commun. to A. A. Drake, Jr., 
In the Stroudsburg quedrangle, the Union Springs is exposed in anly one placema small shale pit north of a secondary road at the west end of the Glen Brook Golf Course, about I mile southwest of the Stroudsburg Boro IIne. Ten leet of mediur-gray to wedium-darkgray noncalcareous laminated, carbonaceous shale, which weathers moderate-reddish brown to dark-yellowish orange, is exposed, and is referred to the Union Springs Member. An estimated 30 to 40 feet of rock Iles between the base of this exposure to the top of the Buttermilk Falls Limestone. Between 40 and 50 feet of Union Springs is belleved to underlle the covered interval between the Route 191 bridge over Brodhead Creek and the top of the Buttermilk Falls Limestone to the south.

The Stony Hollow Merber is exposed in a number of places in the Stroudsburg quadrangle. One of the best exposures is in Brodhead Creek under the Route 191 bridge, on the south side of Stroudsburg (fig. 52). The unit here consists of about 25 feet of finely bedded to laminated medium-dark-gray to medium-gray, sparingly fossiliferous (poorly preserved brachiopods), pyritic, interbedded calcareous shaly siltstone, silty shale, and argillaceous limestone (fig. 53). The argillaceous limestone beds are continuous, but pinch and swell silghtly along strike. The calciur carbonate content in these rocks, determined by dissolving three samples in hydrochloric acid, ranges from 15 to 65 percent. The calcareous siltstones arerage about 20 percent calcium carbonate. These percentages are in agreement with semiquantitative $X$-ray analyses which show that quartz ranges from 10 to 40 percent, chlorite 5 to 15 percent, and muscovite 10 


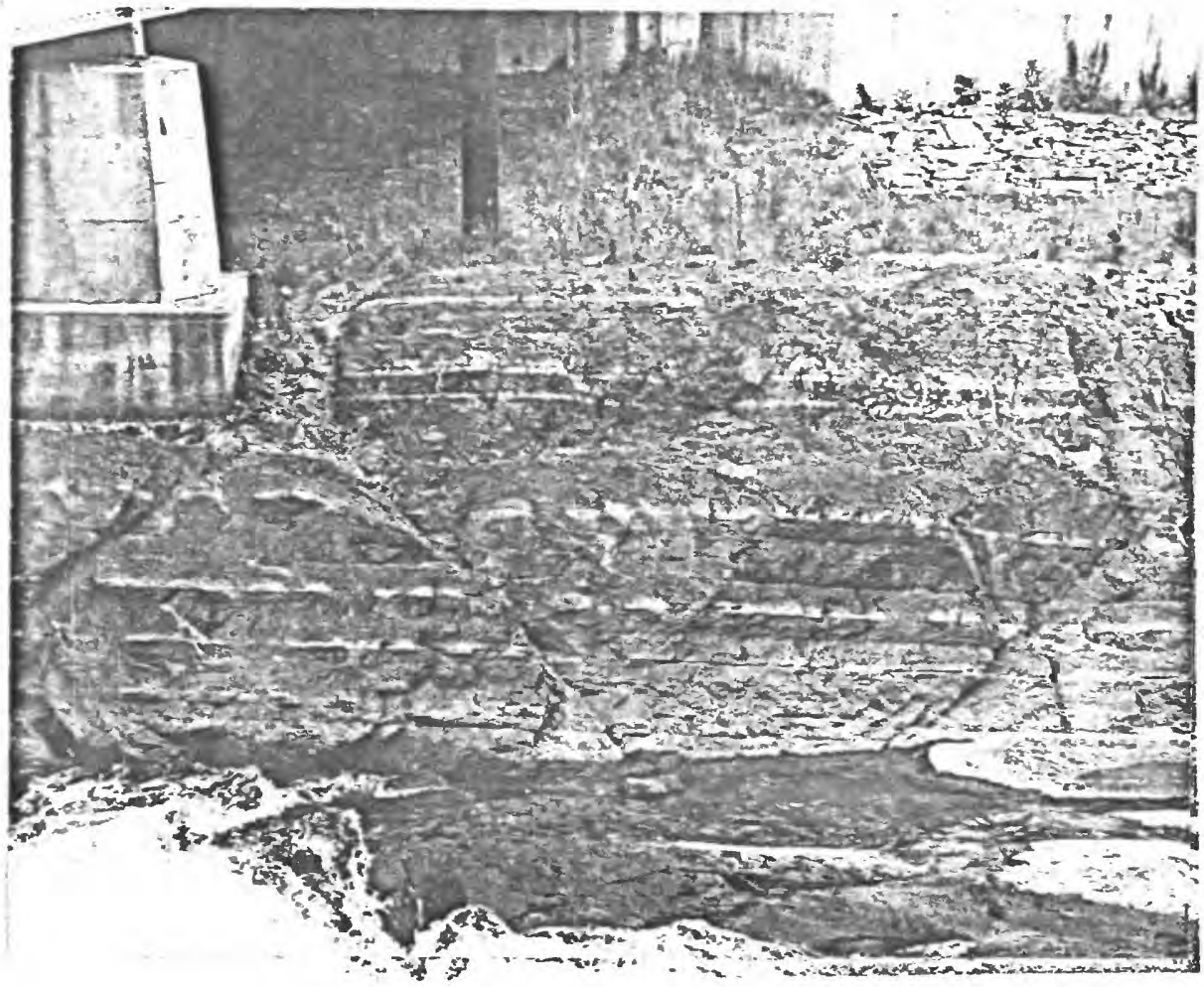

Figure 52. Exposure of the Stony Hollow Member of the Marcellus Shale along Brodhead Creek, under the bridge where Route 191 crosees the creek on the south side of Stroudsburg. The unit Is predominantly calcareous shaly siltstone. Iighter weathering argillaceous lirestone, a few inches thick, is evenly bedded to lenticular. Cleavage dips toward observer. 


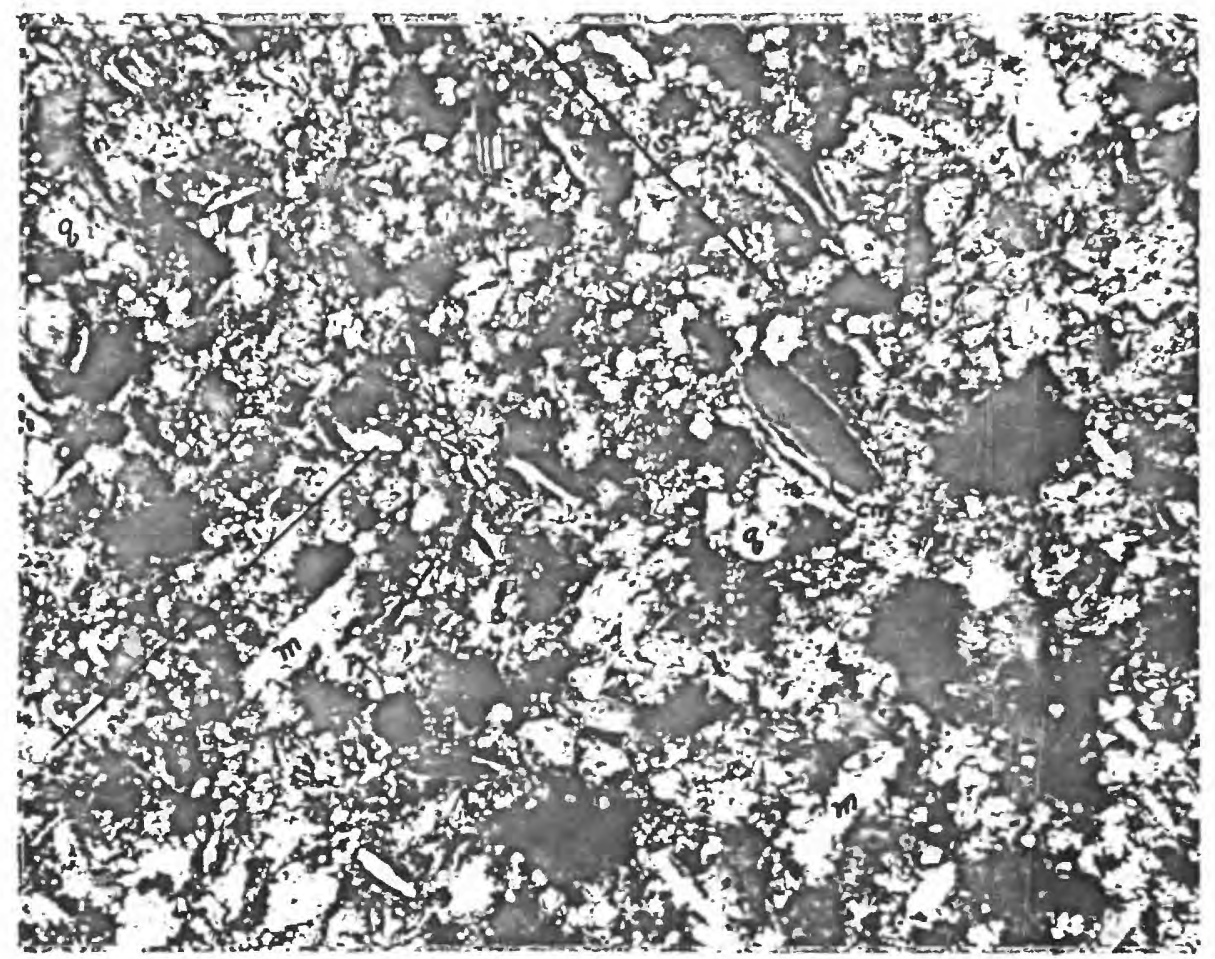

Figure 53. Photomicrograph (crossed polarizers, X 277) of calcareous siltstone in the Stony Hollow Menber of the Marcellus Shale at the same locality as figure 52 . Bedding $\left(\mathrm{S}_{0}\right)_{3}$ cleavage $\left(\mathrm{S}_{1}\right)$ is poorly defined by the alignnerit of muscovite laths $(\mathrm{m})$; pyrite (py); quartz (q); plagioclase feldspar, rare (p); intergrown chlorite and muscovite $(\mathrm{cm})$. Alternating with the siltstone are thin beds of quarizose calcisiltite. 
percent. Rocks higher in the section contain fewer limestone beds and, with the decrease in calcium carbonate, grade up into the Marcellus Shale.

At the shale pit on the west edge of the Glen Brook Golf Course, abont 10 feet of the Siong Hollow is exposed above the Union Springs, and at least an addirional 60 feet of moderately exposed rock overlies it in the hill above. Based on construction of cross sections, the Stony Hollow is estimated to about 150 feet thick in the Stroudsburg quadrangle. Brodhead Creek Member

The Brodhead Creek Kember was named for Brodhead Creek by Willard (1938). Willard described fossiliferous finely arenacecus shale exposed in a shale pit northrest of the intersection of Fulmer Avenue and Wallace Street (one block north of Scott Street and two blocks west of Fifich Street). The member is predominantly dark-gray, laminated to poorly bedded, generally sfaringly fossiliferous, carbonaceous, silty shale and shaly siltstone (fig. 54). Faunal 1ists are given by Willard $(1932,1938,1939)$. The Brodhead Creek contains dark-gray shaly limestone concretions as much as 1 foot long. X-ray diffraction analysis of one sample of a concretion shows it to contain about 55 percent calcile, 20 percent quartz, 15 percent muscovite, and 10 percent chlorite. No microfosstls were recovered from one limestone concretion that was dissolved in dilute acetic acid. The Brodhead Creek Member has a maximum thickness of between 800 and 900 feet, based on construction of cross sections. Ih Ooundaxy with the underlying Stony Hollow Member is not exposed, 


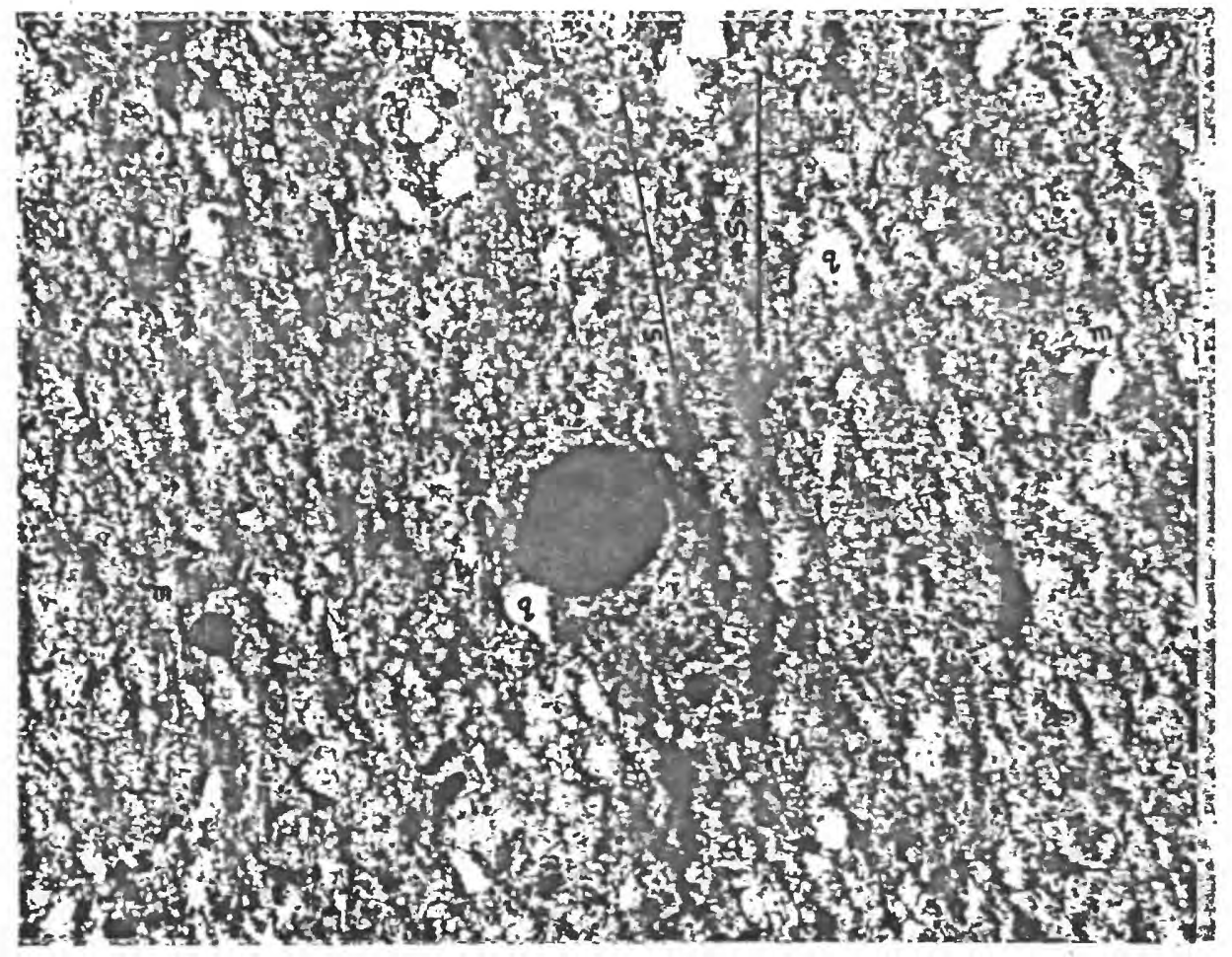

Figure 54. Photomicrograph (plane-polarized light, X 270) of silty shale, Brodhead Creek Nember of Marcellus Shale, roadcut at Interchange 47 of U.S. Interstate $80,0.5 \mathrm{mile}$ southwest of Arlington Heighte. Rock consl.sts of Irregular grains of quartz (q) and muscovite (m) in a finer grouncinass of muscovite, chlorite, and quartz. Only minor pressure-shacion effects are seen on the edge of a spherical pyrite grain (large black grain) in the plane of cleavage. Cleavage $\left(S_{1}\right)$ is faint and marked by some parallelism of platy minerals. Bedding $\left(S_{0}\right)$ makes an angle of $11^{\circ}$ to cleavage. 
Dut is believed to be gradational.

\section{Mahantango Formation}

The Mahantango Formation was proposed by Willard (1935) for strata between the Marcellus Shale and Tully Iimestone exposed along Mahantango Creek in Juniata and Snyder Counties, Pa. Ellison (1965) reviewed previous work on the Mahantango and, along with Willard $(1938,1939)$, presents faunal lists. In Monroe County, Pa., the Mahantango was reported to be 1,200 feet thick by White (1882; his Hamilton S8ndstones), about 1,200 feet thick by Willard (1938), 1,320 feet thick by willard (1939), and 1,400 feet thick by willard and Stevenson (1950). Approximately 850 feet of the lower Mahantango 18 present in the northest corner of the Strovdoburg quadrangle. It is about 2,000 feet thick in the Saylorsburg quadrangle to the west.

The Mahantango in the Stroudgburg quadrangle consists of mediurigray to mediun-dark-gray shaly siltstone to coarse siltstone, but very fine grained sandstone is exposed to the west of the quadrangle. The Mahantango weathers medium gray to grayish orange and is gradational through about 25 to 50 feet of rock into the underlying finer grained rocks of the Marcellus Shale. Very fossilfferous beds are numerous; these contain brachiopods, corals, cephalopods, pelecypods, crinold columnals, trilobites, and other forms. An especially fossiliferous, medium-dark-gray, calcareous and noncalcareous, thickbedded to irregularly bedded siltstone occurs atout 800 feet above base of the Mahantango. This blostrome was designated the 
erfield corel zone by willard (1936b, 1938, 1939), Beerboker (1957), and Beerboker and McDowell (1960). The Centerfield blostrome is exposed at only one locality in the Strouditurg quadrangle--in the roadcut along U.S. Interstate 80 at the west border of the quadrangle (fig. 55). About 30 feet of the blostrome are exposed. The dominant fossils are favositid corals and Hellophyllua, neither of these appear to have moved far froin their grovth position.

\section{QUATERTARY}

Surflcial deposits of Quaternary age unconformably overlie twothirds of the bedrock in the Stroudiburg quadrangle. These consist of Pleistocene glacial deposits of Illinoian(?) and Wisconsin age and Holocene (Recent) sediments of allurial, swam, and man-made origin. These deposits heve been described in detail by Epstein (1969) and are discussed briefly in the section on surficial geology and illustrated in plate $\mathrm{IV}$. 


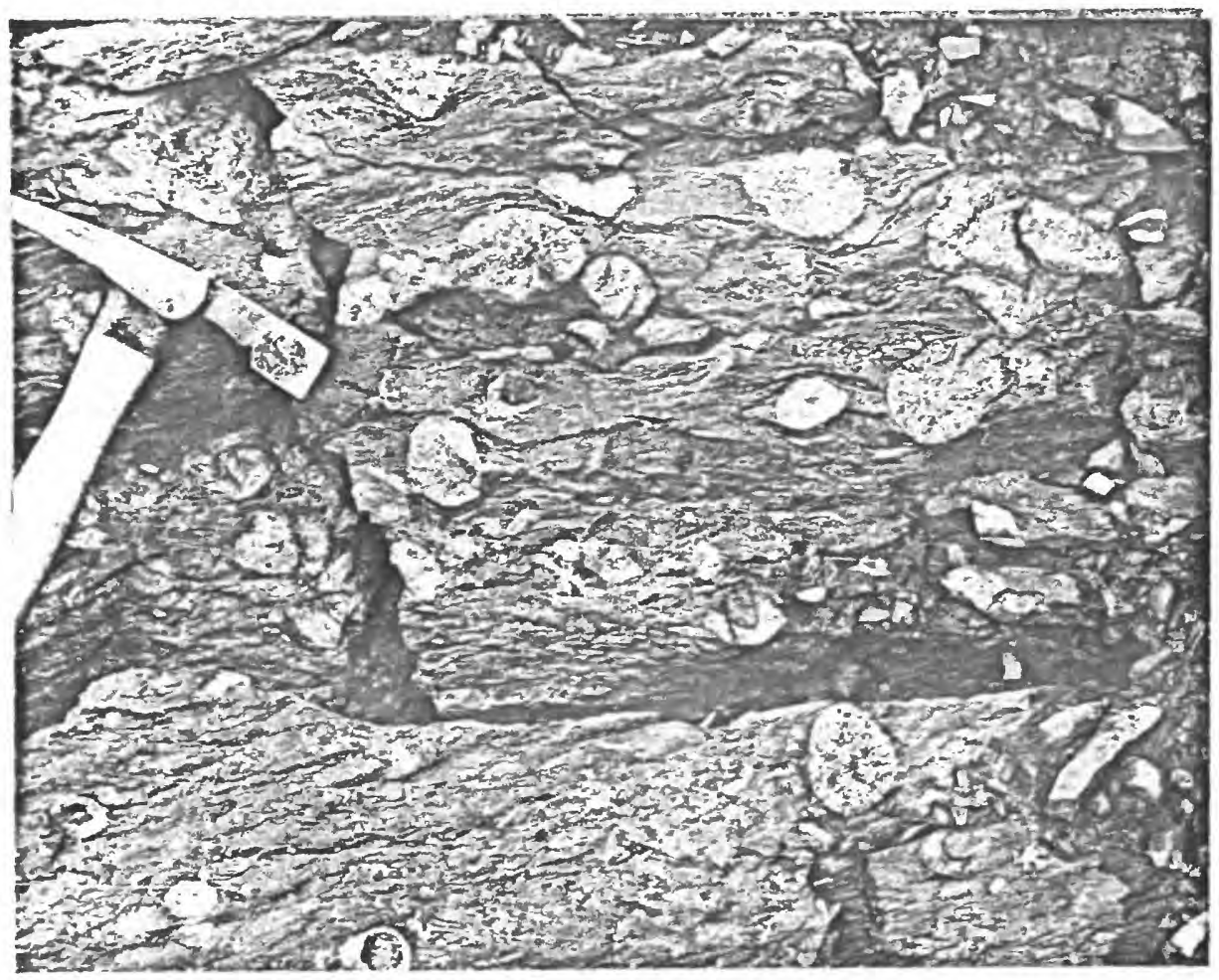

Figure 55. Heliophyilum in poorly bedded calcareous shaly siltstone in Centerileld biostrome of Mahantango Formation, exposed along U.S. Interstate 80 at the west border of the Stroudsturg quadrangle. Note horizontal trace of cleavage that wraps around fossils. 


\section{ENVIROMDENIS OF DEPOSIIIOH}

The Midale Ordovicion through Middle Devonian rocks in the Stroudsburg quadrangle and adjacent areas compose parts of two shelf-flysch-molasse sequences related to two tectonic cycles attributable to the Taconic and Acadian orogenies.

From Cambrian through Late Ordovician time, the Appalachian basin in eastern Pennsylvanfa gradually deepened and the influx of terrigenous sedinents gradually increased. The rock record indicates that the area slowly changed from a supratidal-shallow shelf (Hardyston Quartzite, Leithsville Formation, Allentorn Dolomite, and Beekmantorn Group: dolomite, 11mestone, erkose, and orthoquartzite) to a deeper neritic-flysch basin (fossiliferous calcarenite and calcilutite of the Jacksonburg Iimestone to thick accumulations of rhythwically bedded graywacke and slate of the Martinsburg Formation).

Rocks older than the Martinsburg are exposed south of the Stroudsburg quadrangle. Jacksonburg time marked the onset of flysch-type sedimentation, which culminated in Martinsburg time w1th rhythmic graded sequences of graywacke and dark-gray slate. The graywackes are immature sediments that contain sedimentary features characteristic of deposition by turbidity currents (McBride, 1962; Van Houten, 1954). The Martineburg sediments reflect Taconic orogenic activity, which reached its peak with 
ewergence of the area sometime in the Late Ordovician. The mineralogy of the Martinsburg graywackes, dorinated by muscovite; chlorite, quartz, and calcite, with minor amounts of biotite (some of which has been retrograded to chlorite), high scdic plagioclase feldspar, and a mature heavy-bineral suite (mostly rare zircon and tourwaline), along with chert and rock fragments of shale and slete, which together indicate a source including low-grade metamorphic and sedinentary rocks with possible contributions from volcanic rocks.

The Martinsburg is succeeded by a molesse and carbonateorthoquartzite sequence of Silurian to early Midale Devonian age. The inferred environments of deposition of these rocks in the area between the Stroudsburg quadrangle and Lehigh River in eastern Pennsylvania is shown in figure 56.

The Silurian clestic sequence in the Stroudsburg area (Shawangunk-Bloomsburg interval) consists of four distinct units: a basal sandstone and conglomerate (Mins1 Member of the Shawangunk Formation); interbedded very fine to medium-grained sandstone, siltstone, and minor shale (Clinton Member of the Shawanguns Formation), a sandstone-conglomerate unit similar to the basal member (Tamany Kember of the Shawangunk Formation); and an upper redbed sequence dowinated by repretative fining-upward cycles of fine- to coarse-grained sandstone, siltstone, and silty shale. These form a clastic wedge derived from sourcelands to the southenst that rose during the Taconic orogeny. 
Figure 56. Generalized blcok diegram showing sedimentary nvironments and major Iithofacies in northeasternmost Pennsylvania rom Silurian through early Midale Devonian time.

lluviated coastal plain

1, Streams of high gradient, coerse loed, low sinuosity (braided). $A$, Bedforms in upper flow regitie (planar beds, antidunes) and upper lower flow regime (dunes); chiefly conglomerate and sandstone; lower conglomerate untt of Shawangunk Formation, 12 miles southwest of the stroudaburg quadrangle.

$B$, Bedforms in lower upper flow regime (planar beds) and upper lower flow regine (dunes); chiefly conglomeratic quartzite and quartzite; Minsi and Tamany Mewbers of the Shavangunk Formation.

2, Streams of low gradient, medium load and fine flood-plain deposits, high sinuosity (meandering). Bedforms in Iower flow regiwe (dunes and ripples). Sandstone, siltstone, and shale. Bloomsburg Red Beds and Poxono Island Forution.

\section{IdaI flats}

3. Supratidal flat, may include tidal creeks. Dolomite, limestone, shale, sandstone. Laminated (algal), massive, mud-cracked, intraclast8, sparse fauna. Clinton Meuber of Shewangunk Formation and Poxono Island, Rondout, and Decker Formations.

4, Intertidal flat, may include tidal channel and gully, estuary, logoon, beach. Shale, siltstone, sandstone (equivalent limestone in areas of low terrigenous influx), minor nodules and oolites of collophane, siderite, and chlorite. Irregularly bedded and laminated, graded, rippled, flaser-bedded, cut-andfill, ball-and-pillow structure, burrowed; restricted fauna. (Lingula, Dipleurozoa, eurypterids in noncarbonates; abundant leperditild ostracodes in carbonates). Clinton Mewiber of Shavangunk Forwation, Poxono Island Formation, Bossardville Limestone, and Rondout and Coeymans Forrations.

\section{arrier zone}

5, Offshore bar and beach. Conglomerate, sandstone, and siltstone, and equivalent limestone. Foreshore laminations, crossbedding, scouring, abundant wave-tossed shell debris, textural maturity. Clinton Member of Shawangunk Formation, Decker and Coeyrans Formations, Oriskany Group, Palmerton Sandstone 2 miles west of the Stroudsburg quadrengle. 
Neritic zone

6, A, Upper neritic. Cherty, calcisiltite and calcareous siltstone, unevenly bedded (burrowed), diverse fauna, and B, B10herm and blostronal bank. Biolithite and biogenic liwestone containing minor terrigenous sediment. Decker, Coeymans, and New Scotland Formations, Minisink Limestone, Port Evien Shale, Oriskany Group, Schoharle Fortation, Buttermilk Falls Lixestone.

7, Lower neritic. Shaly siltstone, calcareous shaly siltstone, and calcareous shele. Laminsted, burroved, skeletal debris less abundant than in upper neritic. New Scotland Formation, Port Ewen Shale, Esopus and Schoharie Formitions. 


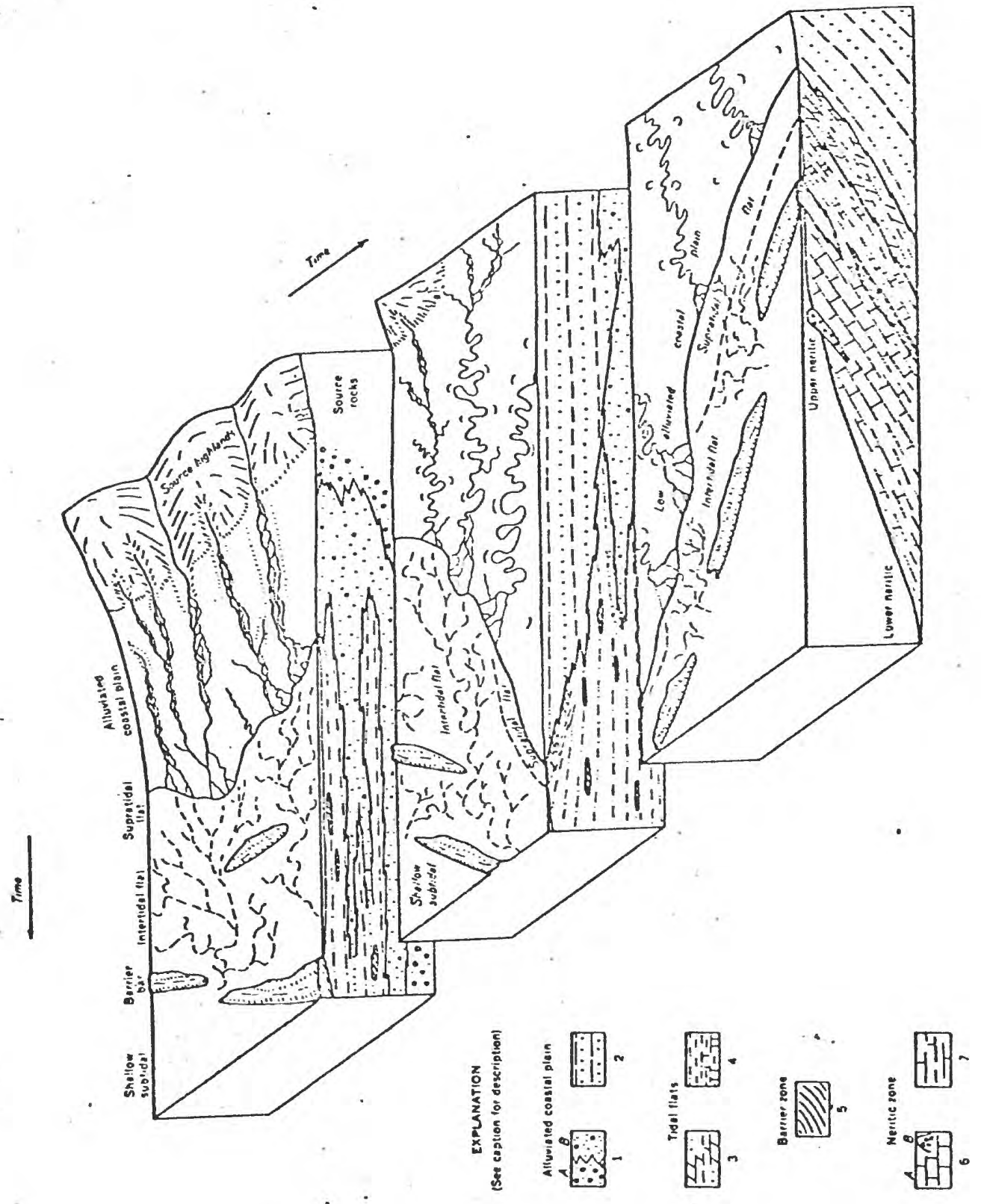


This clastic wedge is considered to be predominantly fluvial in origin, but the Clinton Meaber is a transitional marine facies and parts of the Bloomsburg nay have been deposited in a shallow marine environment. These major enviroments of deposition for the Shawongunk-Bloomsburg interval that I have previously Interpreted (Epstein and Epstein, 1967, 1969) are in general agreement with those of Smith $(1967 \mathrm{a}, 19670)$ and Smith and Saunders (1970) who made and independent study of this interval from Hew York to central Pennsylvania.

In general, previous workers on the Shawangunk have considered it to be predominantly deltaic or fluvial in origin (for example, Grabau, 1909, 1913; Swartz. 1948; Yeakel, 1962; Epstein and Epste1n, 1967, 1969; Smith, 1967a, 1967b), although an exclusively Iittoral origin has been proposed by others (Schuchert, 1916; Willard, 1928).

Initially, uplift was rapid, as evidenced by the unconforwable Shawangunk-lhartinsburg contact and the coarse texture of basal Shawangunk rocks, as shown by the conglomerate unit in the Lehigh Gap area to the west ( $f 1 g .8)$. Sediments become finer from the Mins1 Member through the Clinton Nember in the Strouasburg area. This interval is about 575 feet thick at Delaware Water Gap and about three times as thick at Lehigh Gap. This represents a transgressive phase and the lowering of the source area concomitant with basin subsidence. 
The inftial deposits of this sequence, the conglomerate unit of the Shawangunk Formation at Lehigh Gap (see fig. 8) (possibly present at one time southeast of Delaware Water Gap, but removed by erosion), are characterized by rapidiy alternating conglowerate beds, medium- to very coarse grained sandstone, and very minor argillite. The conglomerates, containing pebbles 88 wuch as 6 Inches long, are indistinctly bedied to planar-bedded and the sandstones are planar-bedded to crossbedded, indicative of relatively rapid flow (upper lower flow regime to upper flow regime; Simons and Richardson, 1962; Fabnestock and Haushild, 1962), and probably are channel and bar deposits of streams. Grain size is variable and pebbles are well rounded to subangular, indicative of a fluviatile environment (Sames, 1966). The sandstones are generally imature (high muscovite-chlorite matrix). Paleocurrent trends are unidirectional to the northwest, also indicating a Iluvial environment (Yeakel, 1962; fig. 57). The bedforms and sedimentary structures indicate deposition by streams which had great competency and steep gradients and are characteristic of streaws of low sinuosity (braided). Properties of braided streams have been discussed in many papers; e.8., Doeglas (1962) and Allen (1965a). The lack of channel-fill deposits in channels with relief greater than 5 feet also indicates that the streams were not confined to a single channel but flowed in many anastomosing channels that shifted position continuously. The nearly complete absence of fine siltstone and shale in the conglomerate unit is 


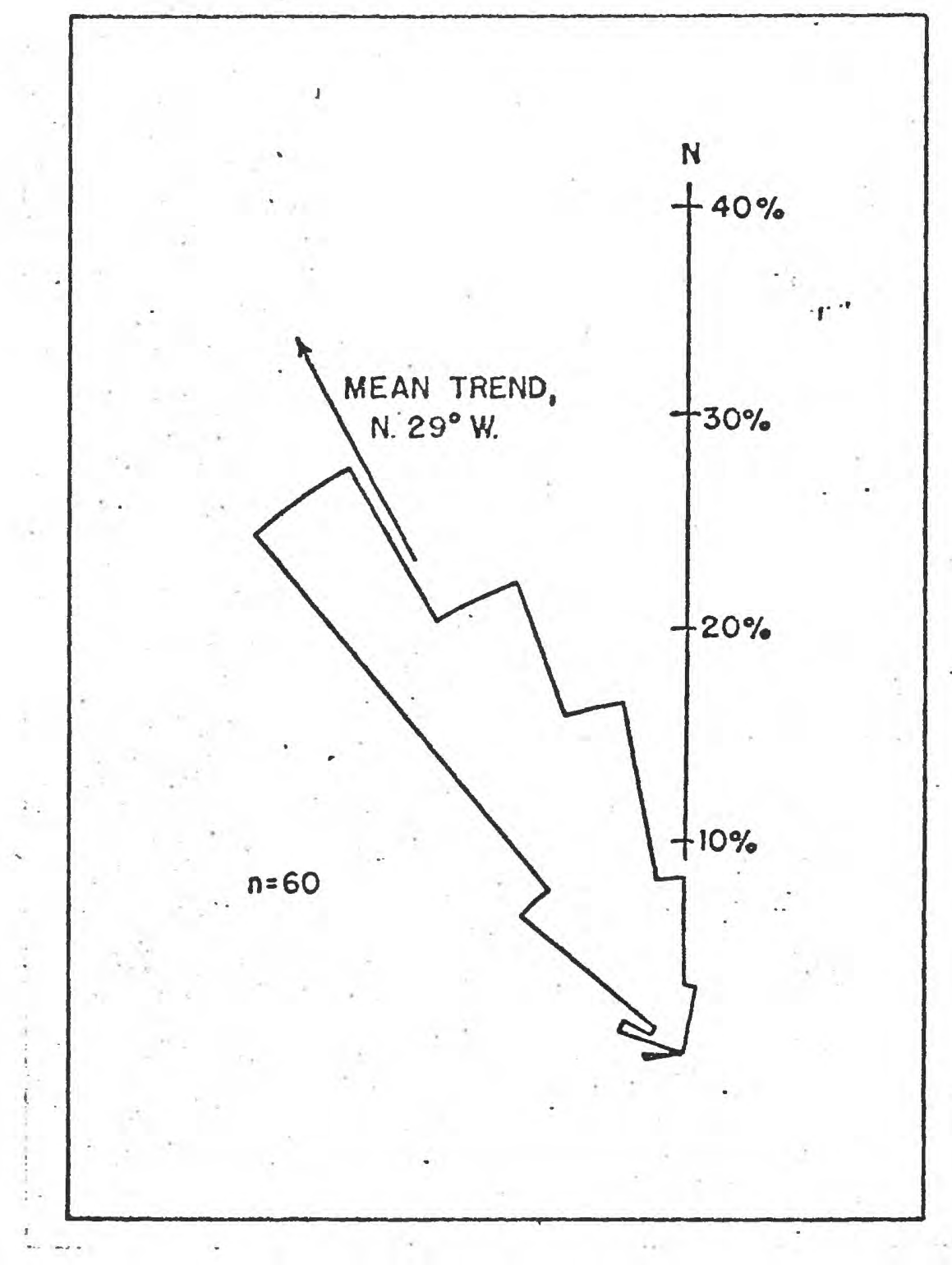

Figure 57. Histogrem showlng current trends from crossbedding In the Shawangunk Formation at Delaware Water Gap. Beds rotated to horizontal. 
also characteristic of braided stream depostts. Braided streams shift so rapidy across the fluvial plain that they are able to remove fine-grained sediment. Some of the shale and silt was incorporated in the coerser sedinent as flattened mud balls.

Glaciofluvial deposits of Pleistocene age in the Stroudsburg area are very similar to the conglomerates and sandstones in the Shawangunk (see section on surficial geology). The glacial sediments were undoubtediy deposited by brelded streams with high velocity and coarse losd. Fahnestock (1963) described similar deposits of the White River, Mount Rainier, Wroh.

The Minsi Member, which overlies the conglowerate unit at Lehigh Gap and forms the basal unit of the Shawangunk Formation at Delaware Water Gap (see IIg. 8) Is similar to the conglomerate unit except that pebbles are swaller (less than 2 inches long), and argillites, probably representing overbanls and backwater deposits, are more abundant. Mudcracks in at least one siltstone bed ( $\mathrm{flg}$. 10) show that these deposits were subject to subaerial exposure. Numerous sedimentation units are superposed, as in the conglomerate unft and also represent deposition by braided streams. The finer grain size suggests that the source higblends were lowered or eroded back at this tiue.

The long linear outcrop belt of the lower part of the Shawangunk suggests that It was deposited on a coastal plain of alluviation with a linear source to the southeast. The pebbles In the conglomerate unit are as much as 6 inches long near Little Gap, Pa., suggesting that the Fall Line could not have been far to 
the southeast, perhaps in the axea of the Reading Prons (see Yeakel, 1962). The maturity of the pebbles (quartz, chert, and quartzite) and heavy winerals (preponderance of zircon and tourusilne, many of which are rounded) suggests a sedimentary source. Basal beds in the Sharangunk contain enough potash feldspar (fig. 11; see also chemical analysis 1 , table 2) to suggest that the source was at least partly composed of granufic or gnoissic rocks. The feldspar. and absence of kaolinite in the clay-size fraction (indicated by $X$-ray diffraction studies) may exclude a decply weathered crystalline source, but any kaolinite that way have been present could have converted to muscovite by diagenesis or metemorphism following deep burial. Mainly quartzose and feldspathic metasedImentary rocks and lesser amphibolite, marble, and granitic rocks are now exposed in the Reading Prong (Drake, 1969). Conceivably, equivalent rocks that may have been exposed during Silurian time courd have been the source for some of the Shawangunk, and chertbearing carbonates and quartzites of Cambrian and Ordovicien age could have supplied other components. Hornblende is extremely rare in the Shawangunk, and pyroxene and epidote, all comon in Prong rocks, were not seen in the Shawangunk at Delaware Water Gap. Quartz is the most abundant mineral in pebbles in the Shawangunk. Much of the quartz contains vermicular chlorite, Indicating derivation from quartz veins. The Reading Prong characteristically lacks abundant quartz veins. Could it be that rocks dissimilar to those now found to the southeast were the source for the Shawangunk, emplaced in their position in thrust sheets or 
ap but long since eroded? Drake (1970) reported that a equence of low-grade metasedimentary and metavolcanic rocks are 'ound on the north border of the Prong. These are apparently ounger than the more highly metamorphosed rocks they overlie and fould have been more extensive. They could have been a source Fr much of the Shawangunk.

The coarse clastic rocks of the Minfi Member grade rapidly up Into Interbedded shale, siltstone, anã sandstone of the Clinton rember. Tinis unit is generally exenly bedded (fig. 13) and is interpreted to have been deposited in a corplex transitional (continental-marine) environment.

The Clintonthickens to the west and at Lehigh Gap it is about 1,200 feet thick ( $f 1 g .8$ ). In addition to similar deposits described at Delaware Water Gap, the Clinton contains redbeds, beds with chlorite pellets, phosphate nodules, and Lingula fragments which, as a group, are interpreted as shallow water, transitional (tIdal-flat, lagoon, barrier bar or beach, and other complex environments characteristic of deltas described by Shepard and Lankford, 1959; Coleman and Gagliano, 1965; Bernard and LeBlanc, 1965; Donaldson, 1966) deposits (Epstein and Epstein, 1969; Eunter, 1970) The differentiation of these environments will require more detailed work. The Clinton thins towards Delaware Nater Gap and is replaced by coarser clastic fluviatile sediments of the overlying Tammany Member. This change in fecies supports the interpretation that the Clinton at Delaware Water Gap is partly 
es rine, and partly tidal flat in orfgin; that is, the finer material transported across the alluviated coastal plain was carried into the transitional environment and distributed into a number of subenvironments (fig. 56). This interpretation is consistant with the environment suggested by the fossils that have been found--Arthrophycus in a block of rock in the retaining wall in Delawere Water Gap on the New Jersey side of the river, eurypterIds (Clarke and Ruedemann, 1912), and Dipleirozoa (Johnson and Fox, 1968)( see age of the Shawangunik Formation, p. 46-50).

Deposits believed to be tidal plat in origin consist of irregularly interlaminated to finely interbedded burrowed shale, siltstone, and sandstone. Flaser bedding (ripple lensing, fig. 16), a characteristic of sediments reworked by tidal currents (IËntzschel, 1939) 1s conmon. These beds also contain mud flasers such as have been found in recent tidal-channel deposits (Reineck and Singh, 2967). Phosphate nodules (calcium fluorapatite) are comon in these beds. At Lehigh Gap these nodules are associated with chlorite and siderite which are belleved to be early diagenetic replacements in an agitated environment. Iingula was also found, indicating that water depths were probably less than 60 feet. Many of the LIngula and nodule-bearing beds are interbedded with sandstones belived to be beach or barrier-bar deposits (Epstein and Epstein, 1969). Thus, there can be little doubt that the phosphate nodules are of very shallow water origin. 
pwe crossbedded sandstones containing wud clasts way be Elal channel or tidal gulley deposits (see van Straaten, 196I) or luviatile deposits that prograded out onto the tidal flats. This 11stinction may be difficult to make (Land and Boyt, 1966). Many sandstones in the Clinton appear generally evenly textured and passive in outcrop, but on polished or wet sawed surfaces are inely bedded to laminated (fig. 14). These are mature sandstones orthoquartzites) with primary current lineation; they are interpreted as beach or bar deposits assoclated with the tidal lats. If correct, the paleogeography may have been similar to the chenier plains along the southern coast of Louisiana. Some -1pple-topped sandstones (fig. 15) are similar to the sand-flat sandstones described by Evens (1965). Rare silty sandstones have pill-and-pillow structure, due to soft-rock slumping (f1g. 17), chat were possibly produced during storms. Ore (1964), however, lescribes simflar intraformational deforwation in braided streams, lue to moverient of saturated sediment, a condition also prevalent in tidal flats.

Regression in the Stroudsburg area occurred as fluvial sediments the Tammany Member, similar to those of the Minsi Member, over lapped the transitional environment. As such, the Tammany epresents the topset plain of a delta that was built out over the transitional environment (fig. 8). This regression may have seen localized by the shifting of the site of major stream lebouchwent, rather than due to uplift in the source area, because barse deposits of the Tammany die out to the west. 
he occurrence of ferroan dolonite in the Tammany indicates proximity to salt water that supplied magnesium for dolowitizatton, possibly in the same manner as has been described for the penecontemporaneous dolomitization of limestone in supratidal environments (for example, see Shinn and others, 1965). In the case of the Shawengunk, as herein envisioned, ground water carrying salts in solution from the nearby body of water was enriched in magnesium at or near the surface by evaporation and also by precipitation of gypsum, thus increasing the $\mathrm{Ng}$ :Ca ratio." Capillary action resupplied water to the surface. In this way, the sedipents in the Tamany Newber were dolowitized by the magnesium-rich brines. A certain amount of aridity (evaporation exceeding rainfall), and lack of flushing of the salty ground water by fresh ground water derived upslope, is implied in this scheme. The water body may have been the sea or a lake on the alluviated coastal plain. An inland sea is favored, because the dolomites are within a few hundred feet of the overlying Bloomsburg Red Beds that are interpreted to be of fluvial origin and deposited very close to sea level, but way have also been partly tidal flat in orfgin. Similar replacement by ascending brines may account for the dolomite nodules that are near the dolomite bed in the Tamenany Member, as well as in the overlying Bloomsburg Red Beds.

Fluvial conditions persisted through Midde Silurian time, the braided stream deposits of the Taumany Member glve way to 
reduminantly meandering stream deposits of the Bloomsburg. This ndicates lowering of the source highlands to the southeast.

The Bloomsburg consists predominantly of red sandstone, siltstone, and shale, which occur in poorly to well-defined upwardeining cycles ( $\mathrm{fig} \cdot \mathrm{25}$ ). The cycles are as much as 10 feet thick and consist of, from bottom to top:

(1) Very Iine- to coarse-grained, large-scale crossbedded to planar-bedded sandstone that locally contains red shale clasts as much as 3 inches long. The basal contact is a sharp erosion surface of very low rellef that cuts into the underlying finer beds. The lower fev Inches of the sandstone are locally gray. The abruptness of the basal contact in places is accentuated by beding slippage descrited in the section on structural geology.

(2) Finely interbedded and irregularly interlaminated siltstone and very fife grained sandstone containing strall-scele ripples. Mud clasts occur locally in the sandstone beds.

(3) Shaly siltstone that is extensively burrowea is indistinctiy wud cracked in places and contains scattered irreguler darkyellowish-orange concretions averaging about $I$ inch in length. X-ray diffraction analysis and staining techniques show that the nodules are ferroan dolorite. The cycle described is somewhat Idealized and does not represent all rocks in the Bloomsburg. Cyclicity in the Bloomsburg is readily explained by vertical and lateral accretion from migrating streams concomitant with n sinking. Each fining-upward cycle represents superposition of beds of successively lower flow regime. 
Jese fining-upward cycles are generally considered to have meen deposited by meandering streams (e.g., Allen, 1965b). The oarse basal sands were deposited in stream channels and point bars hrough lateral accretion as the stream meandered. The wud clasta Tere derived from bank caving. Large-scele crossbedding and plansrredding are indicative of the upper lower and loker upper flow regimes, respectively. These basal beda grade up into laminated pandstone and siltstone containing siall-scale crossbedding that ndicates decreasing flow regime. Similar rocks have been Interpreted to be levee and crevasse-spiay depositg (AIlen, 1965b). fext in succession sre the fine overbank or flood-plain deposits that accumulated by vertical accretion. Burrowing animals obliterated stratification in many of these beds in this low-energy, tranquil environaient. Mud cracks show that aubserial exposure was comon. Evaporation at the surface may have caused the precipitation of calcareous concretions (see Bernerd and Major, 1963; Mocdy-Stuart, 966), but, as mentioned previously, the concretions in the Blocmeburg are ferroan dolomite. It is possible that the Bloomsburg rivers were not far above the strandline, and that the dolcaste concretions may have formed in a high tidal-flat environment by a mechanism similar to the one described for the dolomitization of rocks in the Tammany Member of the Shawangunk Formation.

Fossils are very rare in the Bloomskurg. Fish scales were found near the toll booth at the village of Delaware Water Gap. The fish are belleved to have lived in a fluvial or lagoonal environment cerbower and Hait (1959). Thus, some of the redbeds in the 
10 Durg could have been deposited in shallow marine waters. In many places, such as in the steep-sided valley 0.4 mile north of 'oplar Valley church, the Bloomsburg is made up of interlaninated and finely Interbedded green and red sandstone and siltstone. The colors are believed to have formed at the site of deposition (see (Nalker, $1967 \mathrm{a}, \mathrm{b}$ ) and may mark the oxidation-reduction boundary at or near mean tide level (Mckee, 1957; Nichols, 1962). A similar itustion prevails at the top of the Bloomsburg where tidal-flat deposits of the Poxono Island Fornation are interbedded with red beds in a transition interval a few hundred feet thick (seen outside the Stroudsburg quadrangle). Clearly, the land surface in Bloomsburg time was at low altitudes. Encroachment of the sea over broad tidal flats during Poxono Island time initiated a transgression which continued through part of Early Devonian time.

The above discussion does not mean that all color changes in the Bloomsburg are related to the site of deposition. Certainly the massive color change between the Shawangunk and Bloomsburg Red Beds as seen at the north end of Delaware Water Gap may be due to late diagenesis, as suggested by Horowitz (1969) and Thompson (1970b) for the red-nonred sequences in the central Appalachians. Between Late Silurian (Bloomsburg) time and Oriskany time, deposits in this part of the Appalachian basin are of the marine shelf carbonate-orthoquartzite facies. During the first half of this interval, the rates of sedimentation and basin sinking were about equal and the area was maintained near sea level, so that rocks the Poxono Island through lower Coeymans were deposited in 
flats (supratidal and intertidal) and barrier bars or biostromal banks (Intertidal and shallow subtidel). Repetition of lithofacies characterizes this stratigraphic sequence. These lithofacies are indicative of broad subenvironments within this major shallow marine transgression (fig. 56). Details are given in Epstein and others (1967).

Sediments that accumulated in supratidal flats are characterized by: (I) laminations or organo (algal)-sedimentary origin ( 1 ig. 34); (2) Elightly quartzose, dominantly very fine to fine-grained, laminated and very thin bedded to massive dolorite, limestone, and interlaminated dolomite and limestone; (3) very restricted fauna (nainly leperaltiid ostracodes); (4) mud cracks (f1g. 33). Supratidal sediments occur in the Poxono Island Formation, upper Bossardville Limestone, and Rondout Forrnation.

The intertidal zone can be subdivided into intertidal flats and barrier bars or beaches. Intertidal flat aediments are characterized by: (I) generally graded and rippled laminae to thin beds of slightly quartzose, very fine to medium-grained limestone (fig. 28); (2) cut-and-fill structure, small-scale crossbedding, and intraclasts; (3) abundant ostracodes (mainly leperditilds; figs. 29, 36); (4) scattered beds containing alverse marine fauna belleved to be storm-tossed skeletal debris on a tidal flat behind a barrier bar; (5) rare mud cracks which way have formed during exposure above the intertidal zone (fig. 30). Barrier-bar deposits of the intertidal zone are distingulshed by: (1) quartzose he- to coarse-grained Ilmestone and calcareous sanoistone and 
confonerate contalning foreshore laminations and large-scale crossbedaing (fig. 38); (2) cut-and-fill structure and intraclasts; (3) abundant skeletal debris of a variety of marine organisms;

(4) scattered burrows. Intertidal sediments occur in the Poxono Island Fornation, Bossardville Iimestone, Decker Formation, Rondout Formition, and Depue Ifmestone Nember of the Coeyrens Formation.

Sediments that may have accurulated in the shallow subt1dal zone of a barrier bar are characterized by: (I) Iaminated to bedded, fine- to coarse-grained quartzose limestone and calcareous siltstone to sandstone containing scattered to abundent burrows, (2) flaser beading (ripple lenses), (3) abundant and diverse marine feuma. Shallow subtidal sediments occur in the Bossardville Limestone west of the Stroudsburg quadrangle, Decker Formation, Rondout Formation, and Coeymans Formation.

From Coeymans to Oriskany time, the area underwent a major transgressive-regressive episode. The basin steedily deepened from Coeymans through most of Port Ewen time (sinking exceeded sediment accunulation). Regression began in late Port Ewen time and culminated with post-Oriskany emergence.

In northeastern Pennsylvania, the Lower Devonian outcrop belt crosses several Early Devonian depositional zones. In Coeymans time, the shoreline probably lay near Hazard, Pa., about 20 miles southwest of the Stroudsburg quadrangle, and areas southwest of were probably emergent (Epstein and Epstein, 1969). S1It, 
and gravel were carried into the basin by streams and spread liong the shore as bars by marine currents (Stormille and Peters (alley Mexbers of the Coeymans Fornstion). Ostracode blosparrualtes If the Depue Limestone Member of the Coeymans Forwation (fIF. 36) -rere probably deposited in a protected lagoon behind the Peter6 Valley bar or biostromal banks of the Shawnee Island. Areas tore distant from shore, or areas receiving less terrigenous material, were occupled by blostromal banks (Shawnee Island Member of the Coeymans Fortation). These rocks are generally burrowed silty and sandy biosparrudites ( $\mathrm{fig} .37$ ). In areas of inconsequential terrigenous sediment influx, reefs grew during Shawnee Island time (Epstein and others, 1967). A flood of terrigenous meterial, the Stormville Member (fig. 38), entered the basin at the end of Shawnee Island time and was spread as bars as far northeast as Wallpack Center, N.J., about 25 miles northeast of the Stroudsburg quadrangle.

A deeper subtidal phase followed stormillle deposition. Rickard (1962) interprets the 11thofacies of the New Scotland Formation and Port Ewen Shale as indicative of a deep neritic environment. From New Scotland through most of Port Ewen time, the basin slowly subsided (fossiliferous burrowed quartzose calcilutite and calcisiltite containing beds and lenses of very fossiliferous limestone, both having an abundant benthonfc fauna, and beds and lenses of chert, gradually give way to laminated guartzose calcisiltite and calcareous siltstone with a less aloundant fauna). Sediment influx exceeded basin deepeuing from 
Prt Even through Oriskany time. Deposition, however, was Dntinuous, and a gradual transition from a deep-water to shallowEter nertic shelf environmient proceeded from Port Ewen to Oriskany ime. The abundance of bioturbation structures and skeletal ebris increases from the base of the Port Ewen into the Shriver hert of the Oriskany Group (figs. 4I, 43). In late Oriskany time Ridgeley Sandstone), the strandline continuousiy shifted and bar- ler bar or beach deposits were laid down, consisting of lenses and jeds of laminated, planar-bedded, and crossbedded quartzose sandtone and conglomerate with abundant thick-shelled spiriferid orachiopods (Spirifer arenosus). The coarse beds abruptiy overlie and grade up into beds of quertz calcisiltite containing abundant brachiopod hash, probably of a shallow subtidal probar apron (fig. 42). Seilacher (1968) also interpreted the Oriskany as a beach deposit based on its faunal characteristics--heavy shelled brachlopods that are fragmented and worn along with lack of foreign faunal elements indicate considerable reworking in place. The entire area was emergent following Orlskany tire.

Deep nexitic conditions were re-established following postOribkany emergence. Shallow neritic deposits of this transgression are absent. The Esopus Fornation and lower part of the Schoharie are interpreted to be deep neritic deposits because of abundant lateral burrows (Taonurus, fig. 46) which are placed in the deepderitic Zoophycos facies by Seilacher (1967). PIicka (1968), on the other hand, belleves that "Zoophycus" are prostowla of marine morms. Sellacher's interpretation is favored because in cross 
Taonurus resembles burrows seen in other rocks in the =er, and individual paths of the trace fossil cut across others fig. 58).

Shallowing of the basin is interpreted to have occurred in pper Schoharie time because Tronurus disappears and long vertical urrows become prowinant, and because the Schoharle grades up into the shallow nerttic cherty and argillaceous limestone of the 3uttermilk Falls. The Buttermilk Falls Limestone contains an xbundant and diverse fauna including corals, suggesting depths within the photic zone and warm, well-oxygenated, and gently circulating Hater.

The carbonaceous, pyritic, sparsely fossiliferous, laminated shales of the Marcellus are belived to represent sublittoral conditions below wave base in a reducing environment. These rocks have not been studied in any detail, but this interpretation is strengthened by comparison with similar rocks (e.g., Ellison, 1965; Friedman and Johnson, 1966) and gradation of the Marcellus into the Mahantango Formation, a probable neritic siltstone with abundant fossils, biostromel layers, and coquinite lenses, and including the Centerfield biostrome with abundant corals. Apparently, there was generally rapid and fluctuating sedimentation during Mahantango time. Coquinites and very fossiliferous beds xepresent periods of low clastic influx; poorly fossilfferous beds reflect flooding of the living niches and perhaps killing off of Inal populations which were re-established in different areas and 8tratigraphically at different levels. 


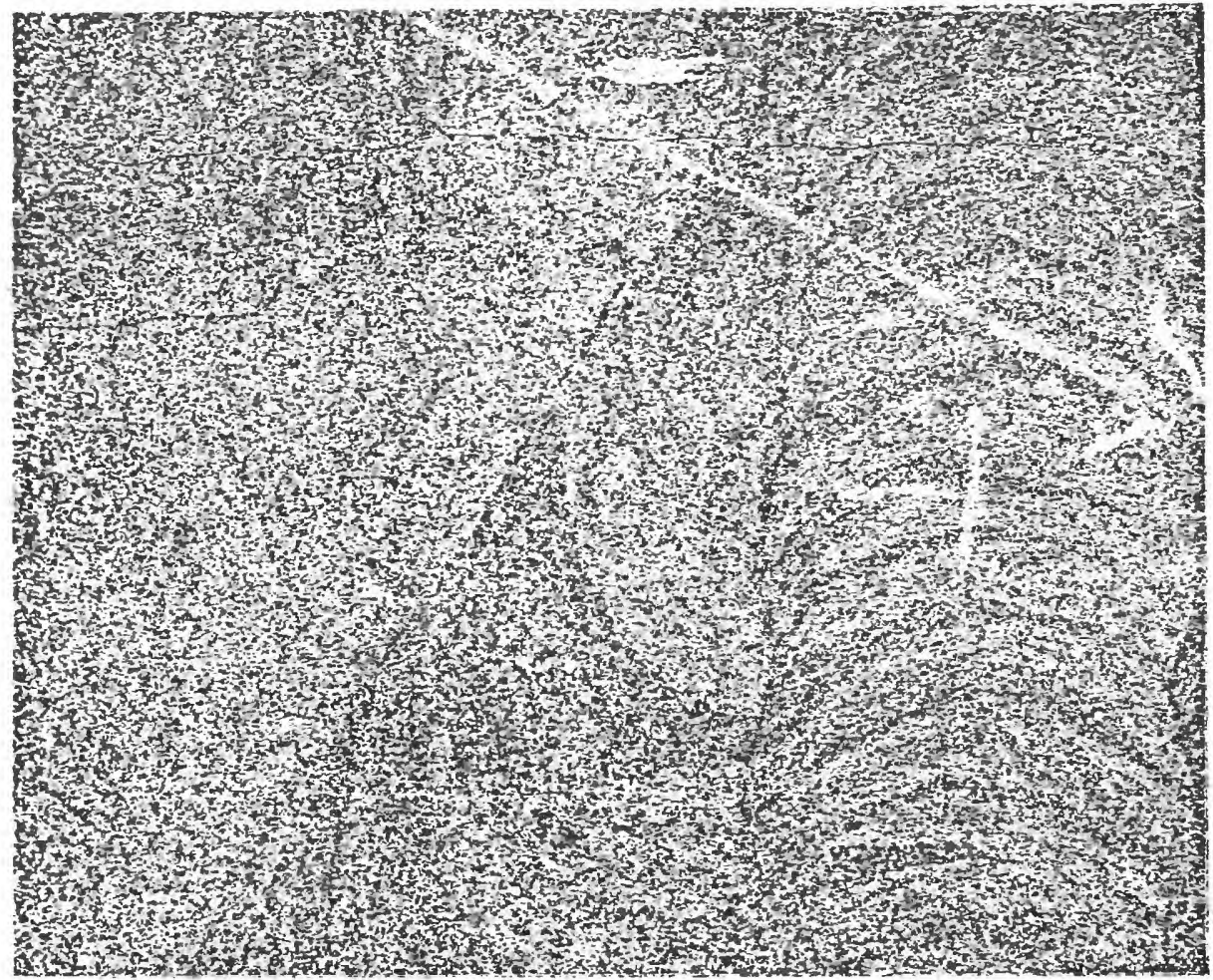

Figure 58. Crosscutting burrows (Teonurus) in coarse quartzmuscovite-chlorite siltstone, Esopus Formation, 650 feet southwest of WVPO radio tower, Godfrey Ridge. Negetive print of thin section $(X 7.5)$. Dark laminee are more quartz-rich than lighter laininae. Horizontal lines are cleavage. White markings are orientation scratches on thin section. 
The Mahantango Formation is the youngest bedrock unit in the stroudsburg quadrangle. Beyond the quadrangle, the Mahantango is overlain by the Trimers Rcok Sandstone, an apparently deep neritic deposit, partly of turbidity current origin (composed of beds containing transported fossil hash at the kase). The Trimers Rock is overlain by the deltaic Catskill Formation, thus ending another major transgressive-regressive cycle. 


\section{SURFICIAL GEOLOGY}

Detalls of the surficial geology in the Stroudsburg quadrangle are given by Epstein (1969) and Epstein and Epstein (1969). A brlef sunmary is presented here. Abbreviated descriptions of the deposits are given on plate IV.

The Stroudsburg quadrangle is within the Valley and Ridge and Great Valley physiographic provinces. Evidence of at least two glaclations is indicated by one deeply weathered till, possibly Illinoian in age, and another fresher till and melt-water deposits of Wisconsin age. After deglaciation, alluvial fans, alluvium, talus, and swamp deposits accumulated.

\section{Illinolan(?) Glacial Deposits}

IIIInolan(?) drift is poorly exposed. It caps bedrock around slate quarries in the West Bangor area, in the southwest corner of the quadrangle. It consists of compact grayish-orange to darkyellowlsh-orange silty clayey till, lacks stratification, and is poorly sorted. Angular to subrounded quartzite boulders, mostly from the Shawengunk Formation, are numerous. These have a weathering rind as much as 2 inches thick. No limestone fragments were found. The till is leached to a depth of at least 10 feet, and weathering has advanced down to the slate bedrock. As 
de mined by $\mathrm{X}$-ray diffraction techniques, the clay-size fraction consists of chlorite, illite, quarta, bematite, and kaolinite. The kaolinfte is belleved to be a prolonged weathering product of reldspar. The greater depth of leaching, rubification, more muddy texture, lack of limestone pebbles, and presence of kaolinfte, as well as more subdued topography, stands in sharp contrast to the younger Wisconsin drift and suggests a long period of interglacial weathering. Thus, this older till may be Illinoian in age, or even older.

\section{Wisconsin Glacial Deposits}

Glacial sediments of Wisconsin age are composed of varying proportions of gravel, sand, silt, and clay. On the basis of texture, internal structure, bedding anā sorting characteristics, and generally well preserved landforms, the deposits are subdivided into till (ground, end, and terminal moraine (fig. 59) and stratified drift (delta, glacial-lake-bottom, kame, kame-terrace, and outwash deposits; f1g. 60). Plate IV shows the location of these deposits.

Numerous striae, grooves, and rouches moutonnée formed by Wisconsin glacial erosion are found on bedrock surfaces in most parts of the quadrangle. The trends of atriae show that the ice Was strongly deflected by underlylng bedrock topography. Average direction of flow of the ice sheet was about S. $20^{\circ} \mathrm{W}$. Similar festures are not found beyond the Wisconsin drift margin, and can be ascribed to IIlinolan(?) glaciation. 


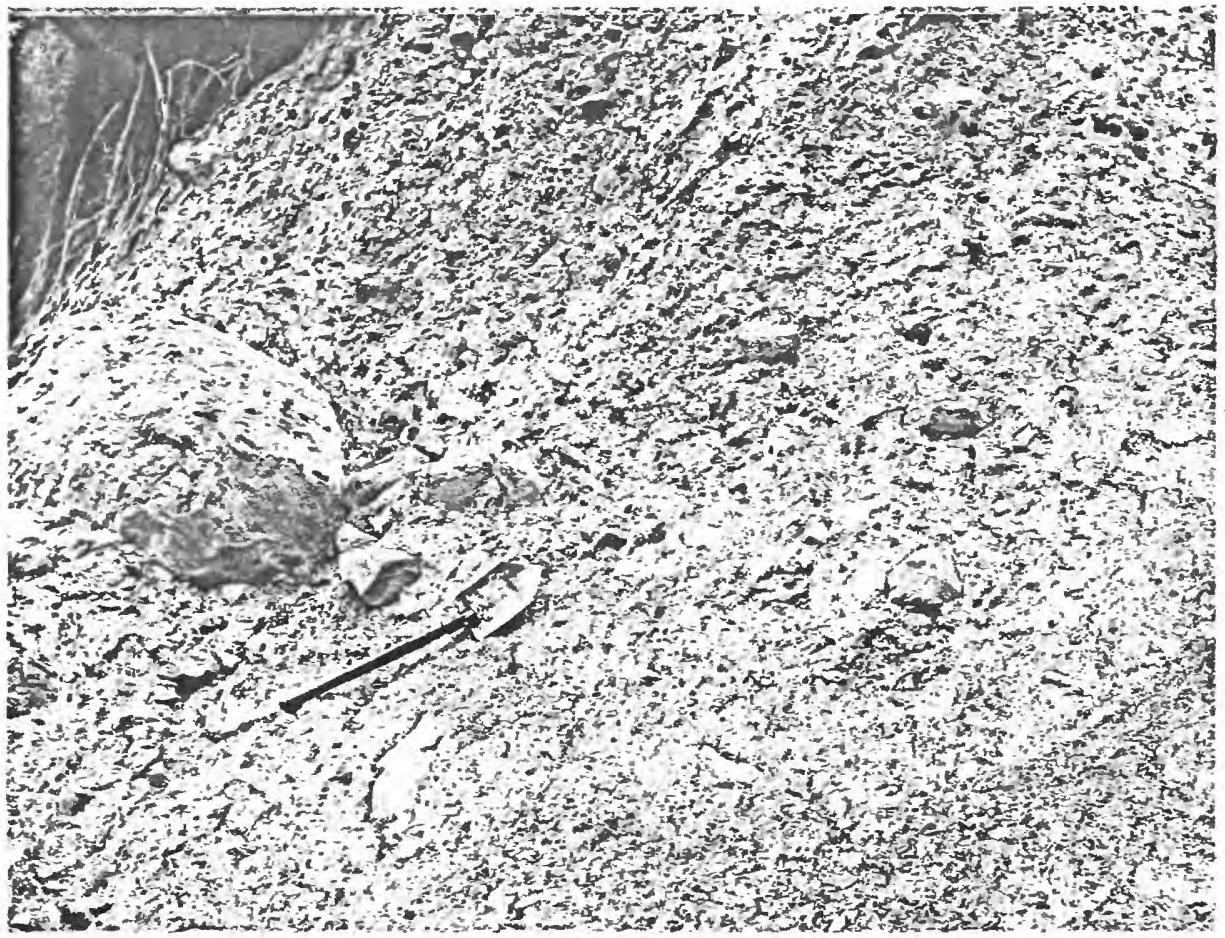

Figure 59. Wisconsin till exposed in cuts along the ErieLackawanna Rallroad (formerly the Delaware, Lackawanna, and Western Railroad) at semple locality ób, plate IV. The till is a silty sandy gravel with boulders as wuch as 10 feet long. A sample collected from this exposure was very pcorly sorted $\left(s_{0}=21.0\right)$. 


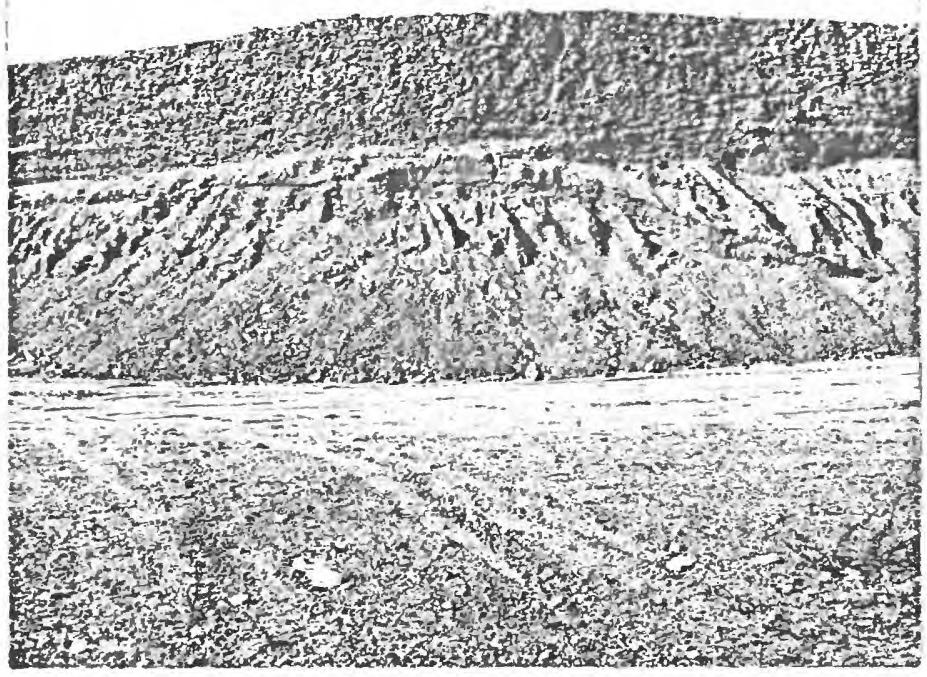

Figure 60. Coarse topset beds beveling finer foreset beds in delta deposit. Gravel pit of Javelyn Mobile Mix, Inc., in Arlington Heights. Belght of face about 25 feet. 
Phases of Deglaciation

Successive phases of 1ce-twargin retreat northeastward across the quadrangle are shown on plate IV. Aress of ice stagnation are characterized by ice-contact deposits such as kames, whereas end moraines and certain deltas are interpreted to reflect the front of active ice.

A conspicuous terminel moraine (Bangor moraine) in the southwest corner of the quadrangle marks the limit of Wisconsin glaciation (phase 1). Widespread ground moraine, locally more than 100 feet thick, containing boulders more than 30 feet long, was also deposited. Because the slope of the land just in front of the terminal moraine was northeastward, toward the Delaware River, a basin formed in which lake clays accurnlated (fig. 61). The pre-Hisconsin drainage divide lay about 5 miles west of Saylorsburg where the valleys are narrowest. Melt weters from the northeastward-retreating ice were trapped between the ice front and the terminal woraine, forming a lake, Lake Sciota. Lake Sciota was probably continuous with the lake in front of the terminal moraine through the col in the moraine at Saylorsburg. Ice-marginel deltas and rhythmically laminated lake beds were latd down in the pro-glacial lake in the Saylorsburg quadrangle during phase 2 (fig. 61). Perhaps the end moraine south of Kittatinny Mountain formed at this time. At first, the outlet of Lake Sciota was acrosis the terminal noraine at Saylorsburg at an altitude of about 680 feet, to which the first delta to have med in the stroudsburg quadrangle (phase 3) 1s graded. The lake 


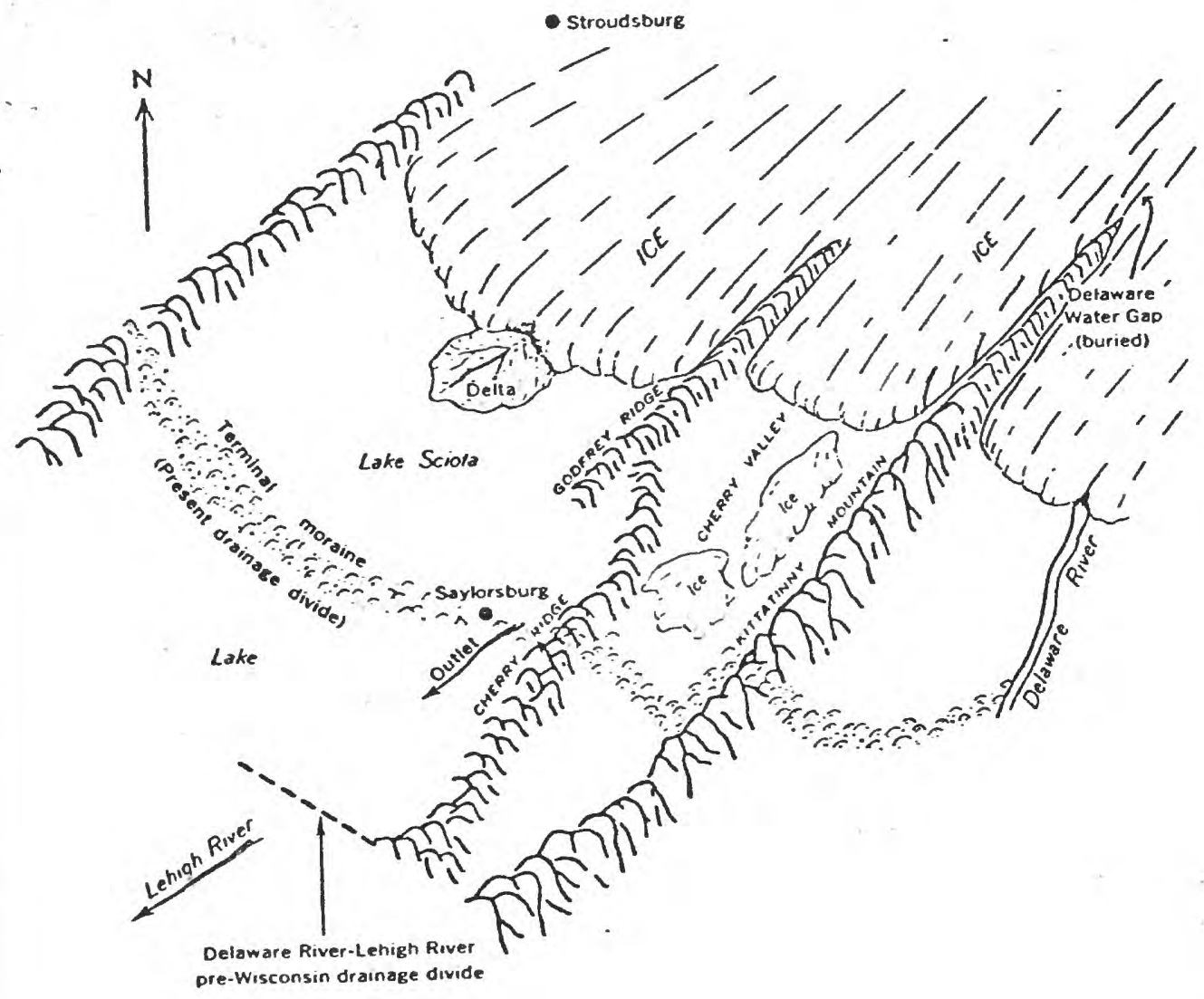

NE

sw pre-Wisconsin drainage divide

Lehigh River drainage Delaware River drainage

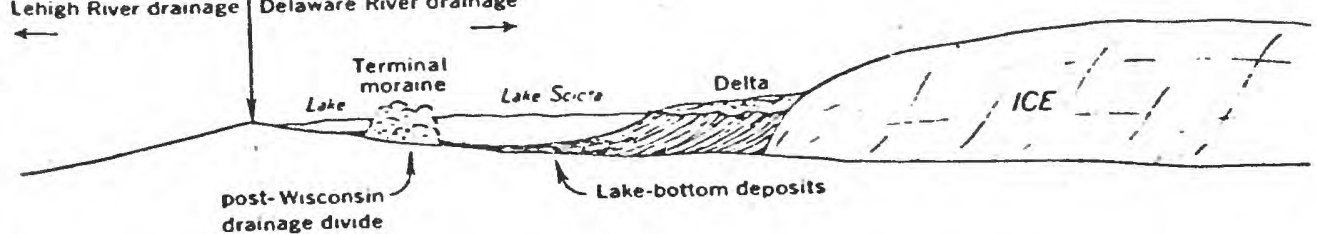

Figure 61. Diagramnatic sketch and section showing preWisconsin drainage divide and position of Wisconsin glacier at time of deposition of delta in Lake Sciota (Saylorsburg quadrangle) during deglaciation phase 2. A kame moraine (not shown in sketch) was built in Cherry Valley at this time. The terminal moraine marks the present Delaware River-Lehigh River drainage divide. . 
atned its level during con'inued ice retreat and a linear kame was deposited north of Godfrey Ridge, perhaps subequeously, during phase 4, and a kame terrace was deposited at the north slope of the ridge during phase 5. Kames in Cherry Valley probably mark stagnated ice margins that are related to phases 3-5 north of Godfrey Ridge. The normal retreat of phase 2 was transitional into stagnation of the ice margin during phases 6 and 7. During this time, the level of Iare Sclota dropped continuously as Delaware Watex Gap opened and the lake drained. A kame was deposited in Cherry Valley in the stagnated zone at this time, and deltas were deposited at successively lower altitudes in the Arlington Heights area. Finally, the lake drained.

\section{Late- and Postplecial Deposits}

After deglaciation, alluvial fans, talus, swamp deposits, and flood-plain deposits accumlated. Alluvium of present streams contains admixtures of pebbles and cobbles derived from underlying and surrounding glacial drift, but consists, for the most part, of brownish silt to coarse-gralned sand. Slate dunps are conspicuous features in the area of slate quarries in the Martinsburg Formation. Some dumps rise more than 100 feet above surrounding surfaces. The material consists of waste blocks of slate. 


\section{STRUCTURAL GEOLOGY}

Generalized summaries of the structural geology in the Stroudsburg area are given by Rogers (1858), White (1882), and Willard (1936). Behre (1933) described the structure in the slate quarries In the Martinsburg Fornation in detail. O'Neill (1940) gave a general account of the structure of part of Codfrey Ridge. The structure as depicted by Willard (1938) and given publicity in structural texts by King (1951, p. 99) and Eardley (1951, p. 99) consists of gentl homoclinal northwest dips in rocks younger than the Martinsburg Formation and couplex folds and faults in the Martinsburg. The Martinsburg-Shawangank contact is thus a marked angular unconformity separating structures assigned to the Taconic and Appalachian orogenies.

This structural picture is too simplified. The structure in post-hiartinsburg rocks is certainly more complex than hitherto envisioned. The attempt to subtract structures definitely of Appalachian age from structures found in pre-Silurian rocks, and to be left with the remainder assignable to the Taconic orogeny, meets with perplexing difficulties. Certainly there was a Taconic orogeny--the Silurian clastic wedge and certain structural features attest to that. But it is here tentatively concluded that most of the structural features in the Stroudsburg quadrangle (most folds and minor structures, such as cleavage) are of Appalachian age. 
c folding and large-scale faulting are also recognized. The lature and origin of cleavage in the report area and the age of its formation have of late been of paramount importance in de:Aphering the structural history of eastern Pennsylvania. These will be discussed in detail.

The rocks in the Stroudsburg area can be divided into four ilthotectonic units; that is, four rock sequences of dissimilar lithology and competency that have different atyles of deformation. Each sequence has been deformed semi-independently of rocks above and below and are presuned to be set off from those by décollenents (detachnents along a bassl shearing plane or zone). Type and amplitude of folds are apparently controlled by lithic variations within each lithotectonic unit, and as a result folding is disharmonic (see pl. II). The lithotectonic units, their lithologies, thickness, and styles of deformation are listed in table 3.

Two mechanisms were operative in producing the folds: (1) flexural folding, in which bedding was active and movement vas either by slip (flexural slip) or flow (flexural flow); and (2) passive folding, in which movement was along laminar-flow planes (passive flow) or slip planes (passive slip), and in which bedding was passive and merely indicates deformation in the direction movement (see Donath and Parker, 1964). Flexural-slip folding in the area Is characterized by extensive development of bedding-plane slickensides and by maintenance of constant orthogonal bedding thickness in all-parts of the fold, whereas in flexural-flow folding, thickness 


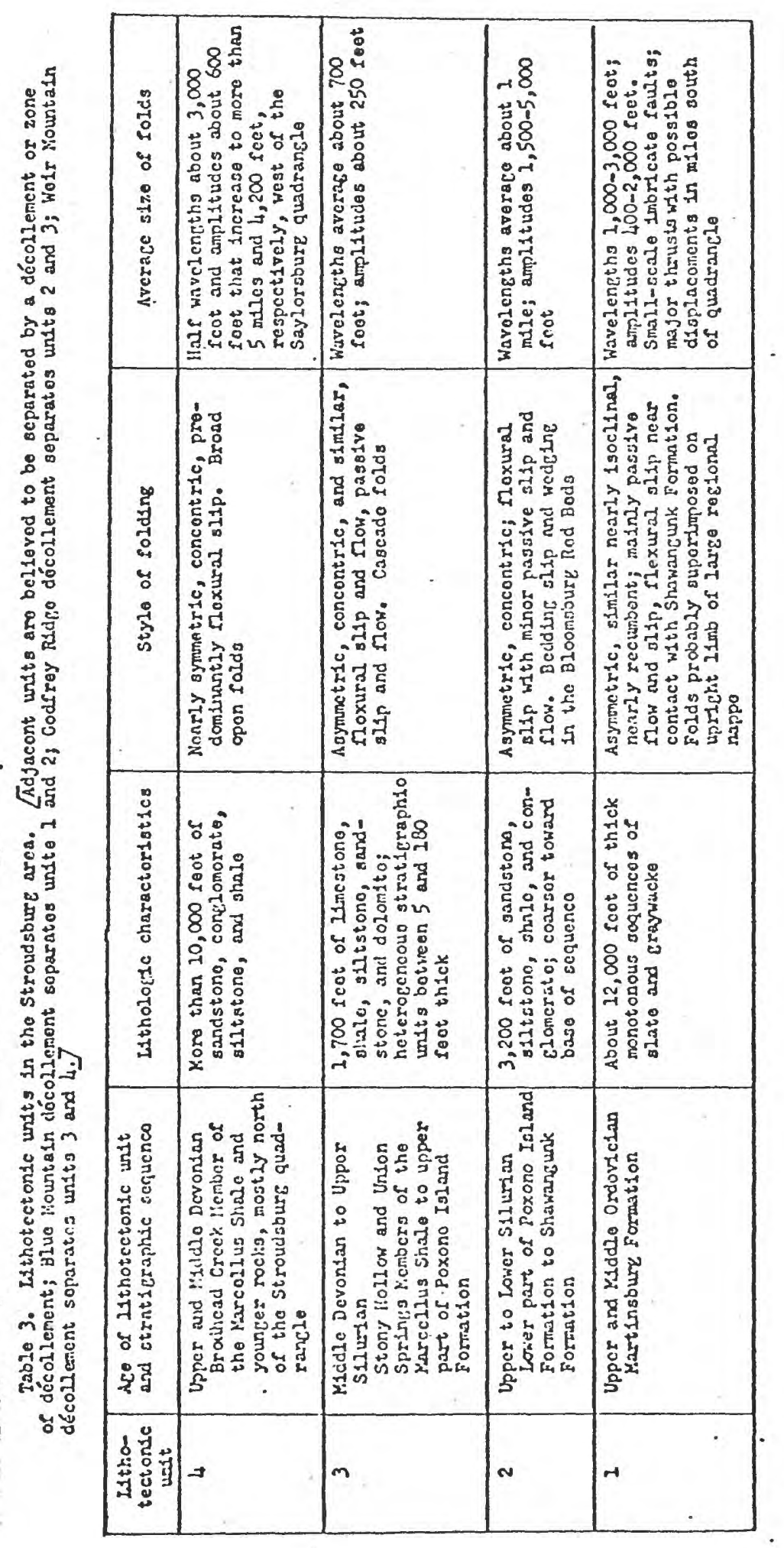


indicular to bedding need not be constant. Passive folds have the shape, or form, of similar folds and corstant axial-plane thicknesses (the length between bedding planes measured along cleavaje, if cleava,e is parallel or subparallel to the axial planes, for example) are generally maintained. If the planes of movernent (the cleavaje planes) are macroscopically discontinuous, the folding is by passive slip, but if the movement planes are so closely spaced as to be indistinguishable to the unaided eye, the folding is termed passive flow.

\section{Décollements}

Three décollements, or zones of décollement in relatively incompetent rocks separate the four lithotectonic units, described in table 3.

The Blue Mountain decollement, parallel to the MartinsburgShawangunk contact, is a zone of detachment between lithotectonic units 1 and 2. The contact is not exposed in the quadrangle, but at the tunnel of the Yards Creek hydroelectric plant on Kittatinny Mountain, 4.5 miles northeast of Delaware Water Gap, and at Lehigh Gap, fault gouge that is several inches thick occurs at the contact, and microscarps or steps on bedding-plane slickensides in the Martinsbur: near the contact indicate northwest translation of the overlying Shawangunk. This sense of movement is corroborated by small drag folds at the contact at Lehigh Gap (Epstein and Epstein, 1969, fig. 22).

A thick detachment zone, the Godfrey Ridge decollerent, separates lithotectonic units 2 and 3. The change in style of deformation between the two units takes place in the Poxono Island Formation. Considerable northwest movement is indicated by wedging and ar beddine slip in the underlyin: Bloomsbur: Red Beds. This will 
be scribed under lithotectonic unit 2 below. The differences in the amount of shortening between rocks in lithotectonic unit 3 as compared to rocks in lithotectonic unit 2 is more than 15 percent, if all the complex folding shown on plate III is considered to be flexural slip. However, some of the folding was passive, so the net difference in shortening is somewhat less than 15 percent.

Differential movement between lithotectonic units 3 and 4 appears to have been concentrated along a zone in the Marcellus Shale (Weir Mountain décollement), but outcrops that would provide proof of the décollement are lacking due to thick drift cover. Because movement on the Godfrey Ridge and Weir lountain décollements appears to have occurred in fairly thick intervals or rock, their general location is shown on plate $I$, but they are not shown in the cross sections on plate II.

Several other explanations for the disharmonic relations between lithotectonic units 2, 3, and 4 are possible. First, the folds in lithotectonic unit 3 may be the result of drag on a southeast-dipping thrust fault that lies in the covered interval of the Marcellus Formation. Thus, the drag folds would not continue under cover to the northwest as depicted in plate II. The fault could be the extension of the Sweet Arrow fault farther to the west (Wood and Kehn, 1961). Its presence could be verified by drilling or mapping to the southwest in the Saylorsburg quadrangle where the fault presumably would cut off the Weir Mountain syncline (see Epstein and Epstein, 19úg, fig. 3). This mapping is currently underway, but the fault hypothesis is tentatively rejected because reconnaissance suggests no crosscutting relationship. Also, the folds in lithotectonic unit 3 are not considered to be drags, because they do not die out southeast of the hypothetical fault. The second possibility is that Iements do not separate the units. Rather, Iithotectonic unit 3 
is self a décollement zone separating strata in the lithotectonic units above and below that have moved relative to each other. This scheme has been described by Kehle (1970). The thira possibility is that there has been no relative movement between the lithotectonic units and that the disharmony is the result of buckling of a series of layers of different competencies (viscosities) (for example, see Ramsey, 196́7, p. 380). Thus, no relative differences in shortening has taken place. The interpretation of décollements separating the lithotectonic units is favored over the last two alternative possibilities because of evidence of northwest translation of rocks as mentioned above and to be described below. Moreover, this interpretation is in harmony with similar interpretations in the Appalachians elsewhere in Pennsylvania (Gwinn, 1964; Wood and Bergin, 1970). Dahlstrom (1959) presented a similar example of décollements separating lithotectonic units in the Fernie Basin of British Columbia.

The detachment zones generally dip to the northwest and may be rootless. Therefore, northwest movement into the Appalachian basin may have been primarily by gravitational sliding off uplifted areas to the southeast, albeit alded by northwest-directed tectonic forces. Upward thrusting from these décollements, as described by Gwinn (1964) in central Pennsylvania, has not been observed in the Stroudsburg quadrangle. Possibly these décollements are similar to or continuous with those described by Gwinn (V. E. Gwinn, written commun., 1967). Examples of small-scale internal disharmony in all lithotectonic units are found in the Stroudsburg area. These will be described under a separate heading below.

\section{Lithotectonic Unit I}

The MartinsburE Formation of Ordovician age comprises lithotec. tonic unit 1. Passive folding was the dominant mechanism of deformaalthough bedding-plane slickensides and its relationships to 
clorage indicate that flexural slip occurred at times both before and after passive folding. Slaty cleavace is the most dominant planar feature, although it is less prominent within a few hundred feet of the Shawangunk Formation. The cleavace fans the folds slightly, especially in silty and sandy beds. In places, the cleavage is folded, comonly near thrust faults, and a second-generation slip cleavare has formed. The intensity of deformation increases to the southeast. In the southern part of the quadrangle, axial planes of folds generally dip gently to the southeast (pl. II), and in places the folds are nearly recumbent. Farther southeast, beyond the Stroudsburg quadrangle, deformation increases to the point where the second cleavarje is locally nearly as prominent as the first cleavarge. To the northwest, axial planes dip more steeply, but disappointingly, thick cover by glacial deposits conceals most of the Martinsburg. In the Delaware River, abundant exposures show that the Ramseyburg Member trends northeastward under the Shawangunk Formation. The Pen Arcyl-Ramseyburg contact is unconformably overlain by the Shawangunk $3 / 4$ mile southwest of the gap (pl. I). The beds in this area dip homoclinally to the northwest with a few small superimposed folds and faults (pl. II, cross sections $G-G^{\prime}$ and $F-F^{\prime}$; see also Drake and others, 1969). Lack of continuous exposures makes it impossible to trace small thrusts for any great distance. The farthest any fault could be traced was about 3,000 feet. While there are no marker horizons to indicate amount of displacement, ! the tracing of one thrust fault into an unbroken fold within a short distance indicates that displacement is not great; possibly less than 100 feet.

The Portland fault in the southeast part of the Stroudsburg quadrangle is the only fault of very large displacement recognized within lithotectonic unit 1 . It has been mapped to the northeast the Portlend quadrangle (Drake and others, 1969) and separates 
ca. nate rocks of Cambrian and Ordovician are in the Paulins Kill valley of New Jersey from rocks of the Martinsburg Formation on both sides of that valley. The belief that the fault traces on both sides of the valley are part of the same fault is proved in the Stroudsburg. quadrangle by sparse water-well data that show carbonate rocks in the lower plate of the fault and slate in the upper plate (pl. I). The fault is folded by the Flicksville anticline and plunges to the southwest under the slate quarries in the East BangorBangor area. It is not recognized in the area of the quarries. In the portland quadrangle, Drake and others (1909) show that the fault cuts bedding at low angles. In places, more than 3,500 feet of strata have been cut out, implying that displacement is at least on the order of miles. The fault can be traced for about 25 miles to the northeast in New Jersey (Lewis and Ktrmel, 1912). Based on geologic and aeromagnetic data, Drake (in U.S. Geological Survey, 1959, p. A. 28) interpreted the Portland fault as extending in the subsurface for about 40 miles southwest of Bangor. He concluded that the fault is part of a large regional nappe that is mostly buried in Pennsylvania and underlies the Musconetcong nappe exposed to the southeast. As will be discussed under the chronology of deformation, the Flicksville anticline, as well as similar folds in the Martinsburg, is believed to be Appalachian in age. The Portland fault is probably a Taconic feature because similar faults are not known In rocks younger than Ordovician Immediately to the northwest. Its regional significance, however, has yet to be deciphered.

The Flicksville anticline is shown on plate I to trend more theasterly than folds west and north of it. This trend may be 
in pror. The axial trace of the Flicksville anticline was drawn to join folds with the same name in the Bangor quadrangle to the south (Davis and others, 1967) and the Portland quadrangle to the east (Drake and others, 1969). In all probabllity it is not continuous with either of these folds but is probably continuous with the anticline southeast of the Old Bangor syncline, and its position shown on plate I could not be corrected before submission of this report.

The Blue Mountain décollement, as mentioned above, separates Iithotectonic units 1 and 2. The amount of displacment is nnknown, but based on Inferences from the Godfrey Ridge décollement, displacement could be thousands of feet or miles.

The best exposures in the Martinsburg Formation, hence places where the most structural detail can be obtained for lithorectonic unit 1 , are in the slate quarries shown on plates $V$ and VI. The Capitol slate quarry (no. I4) is presently the only one active in the Stroudsburg and Portland quadrangles, the others are mostly flooded. A mubber liferaft was used to get into all the quarries except two, the Bangor Central (no. 17) and Bangor Royal (no. 18). Most of the openings have been described by Sanders (1883) and especially Behre (1933), and their operational histories mentioned. However, some were inaccesstble to Behre, many have been modified by quarrying operations since his investigations, and a few require different structural interpretations. 
Fidelity and West Bangor quarries (1)

The Bangor Fidelity is a rectangular opening about 550 feet long and 250 feet wide. Adjoining it to the northeast is the West Bangor quarry with dimensions of 450 to 350 feet. The two quarries are abandoned and are separated by a wall of slate about 100 feet wide. Behre (1933, p. 246) reported that the openings reached a depth of about 300 feet. The dunps to the southeast are about 100 feet high. About 10 feet of Illinoian(?) till caps the northeast part of the openings. The exposed rocks are weathered and consist mostly of slate, but thin silty beds with convolute bedding are not uncommon. The quarries are cut into the overturned West Bangor syncline whose axial plane dips $20^{\circ} \mathrm{SE}$. (fig. 62). A bedding-slip fault is described and 1llustrated by Behre (1933, p. 237, 247). Intersections of bedding and cleavage, which are presumed to indicate the plunge and trend of the fold, plunge to the southirest in the upright limb of the fold and to the northeast in the overturned limb. The fold is, therefore, noncylindrical.

Bangor Superior quarry (2)

Two openings, large square one about 250 feet long and a smaller one to the southwest, make up this quarry. A maximum of 15 feet of bedrock crops out above water, except in the southeast corner. No sandy beds were seen. Between 5 and 10 feet of Illinoian(?) drift covers the slate. The dumps to the east are about 80 feet high. Cleavage dips moderately to the southeast and beds are ght and dip gently to the southwest. Thus, the quarry is 


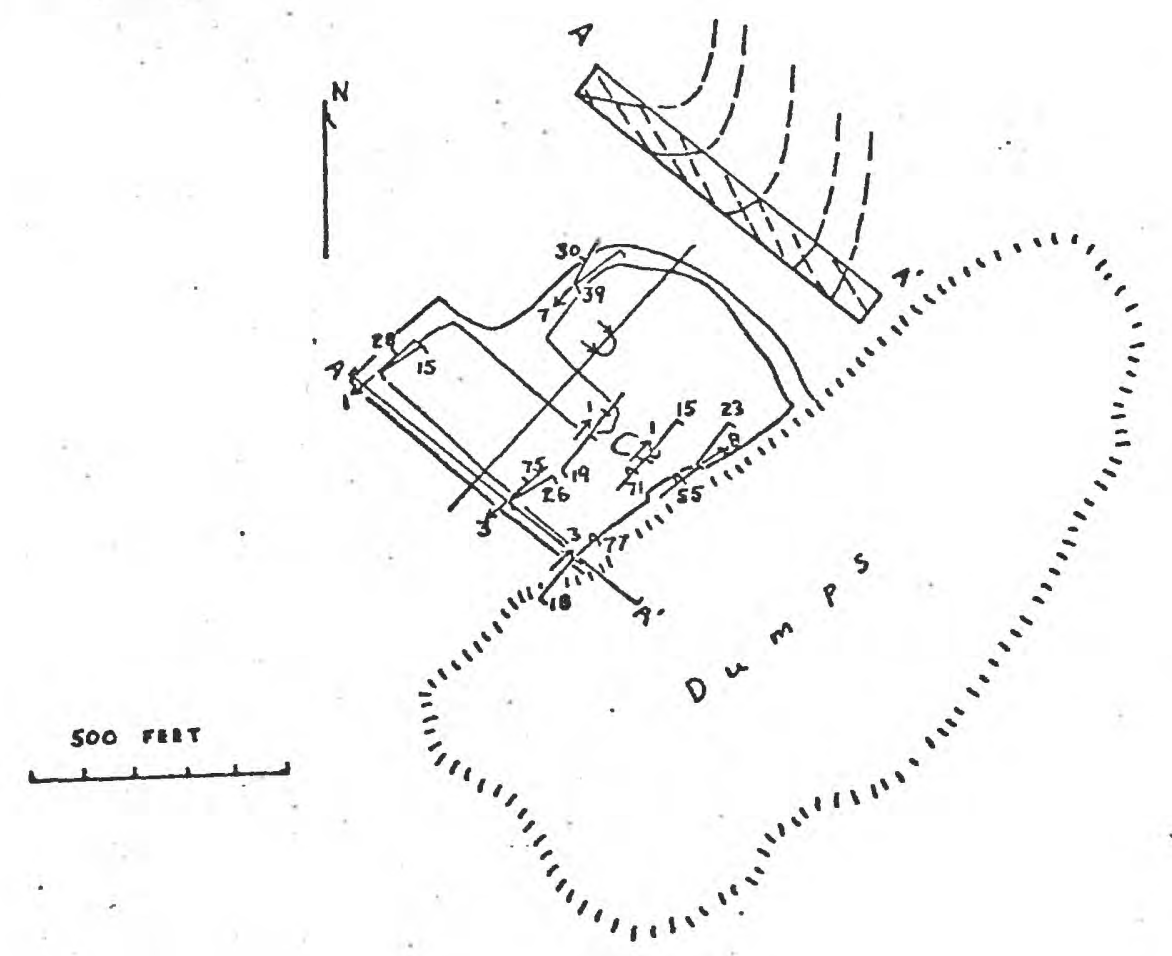

Figure 62. Geologic map and section of the Bangor Fidelity and Kest Bangor quarries. See plate I for explanation of map symbols. Areas of bedrock exposure enclosed by solid lines. In cross section, solid lines are bedding, dashed lines are cleavage. 
loo in the trough of the southwest-plunging overturned syncline exposed in the Bangor Fidelity and West Bangor quariles to the mouthrest.

Northampton quarry (3)

The Northampton quarry is situated on the nose of the gentiy southwest-plunging overturned Roseto anticline whose axial plane dips about $15^{\circ} \mathrm{SE}$. (fig. 63). Behre describes (1933, p. 222) and illustrates (p. 218) a bedding slip fault along which there has been distortion of cleavage. Some of the slate in the quarry is silty. Beds range from about 6 inches to 3 feet thick. About 10 feet of till covers bedrock in the northern part of the quary. The quarry is abandoned and is presently being used as a garbage dump for the borough of Roseto.

Hoboken quarry (4)

In this water-filled quarry, a maximum of 8 feet of carbonaceous slate and lesser slightly calcareous silty beds are exposed, ranging from 1 inch to 2 feet thick. Strike of bedding averages N. $28^{\circ}$ E. and dip ranges between $10^{\circ}$ and $20^{\circ}$ N.S. Attitude of cleavage is consistent--N. $61^{\circ} \mathrm{E}, 37^{\circ} \mathrm{SE}$. Thus, the quarry is in the trough of a broad southwest-plunging syncline which extends at least to the New York quarry (no. 5). The quarry is about 100 feet by 150 feet. The dumps Ife to the northeast and south and are about 30 feet high. New York quarry (5)

The New York quarry is about 230 feet square. The dumps to the are more than 80 feet high. At present this flooded quarry is 


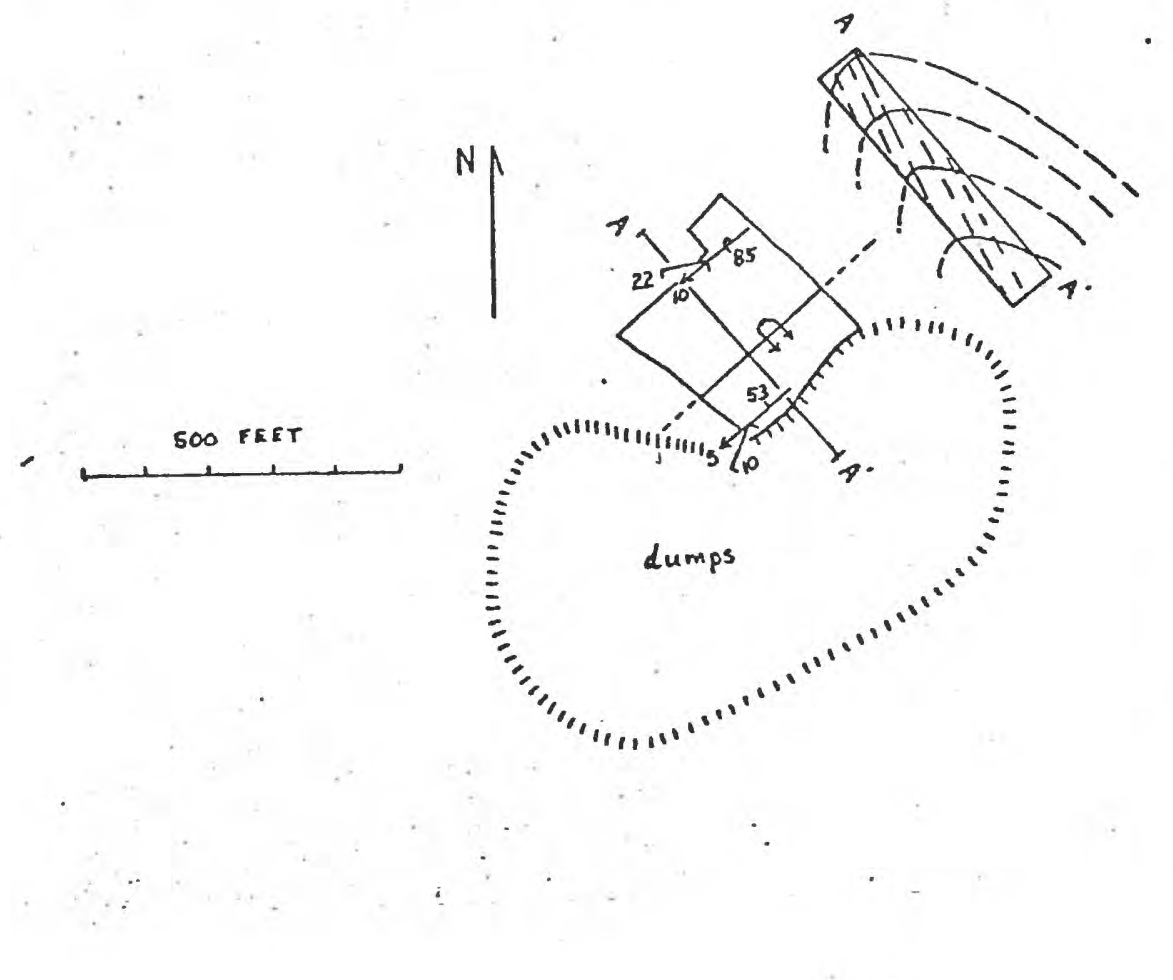

Figure 63. Goologic map and section of the Northampton quarry. See plate I for explanation of map symbols. In cross section, solid lines are bedding, dashed lines are cleavage. 
used for local water supply. The trend of cleavage is parallel to the regional trend of folds, but bedding strikes more northeasterly. Thus, the position of the quarry is in the trough of the same syncline as described for the Hoboken quarry (no. 4). Behre (1933, p. 203) described the quarry in detail and mentions two "loose rlbbons" or calcite-quartz-filled bedding-plane slickensides. These developed primarily prior to the developinent of cleavage. New Peerless (Bangor Vein) quarry (6) and Strunk quarry (7)

These two quarries show similar structures and will be described together. The New Peerless is larger and measures about 650 feet by 300 feet. The Strunk quarry Iies sbout 120 feet to the northeast and is roughly 200 feet square. Drift cover is thin to absent. Dumps to the north and between the quarries rise about 40 feet above water level. The quarries are abandoned, but scine machinery and unworked slate blocks remain. A maximum of 20-30 feet of bedrock is exposed above water level. Slate of varying quality predominates over thin siltstone beds that average about 2 inches in thickness.

The quarries are located in a southwest-plunging, nearly recumbent and isoclinal syncline (West Bangor syncline) that is overturned to the northuest (fig. 64). The axial plane of the fold is exposed in the Strunk quarry (fig. 65), whereas it plunges southwestward beneath water Ievel in the New Peerless quarry and only the upper limb of the fold is seen in the New Peerless (fig. 66). B $\left(1933\right.$, p. 204) reported that the axial plane dips between $8^{\circ}$ 


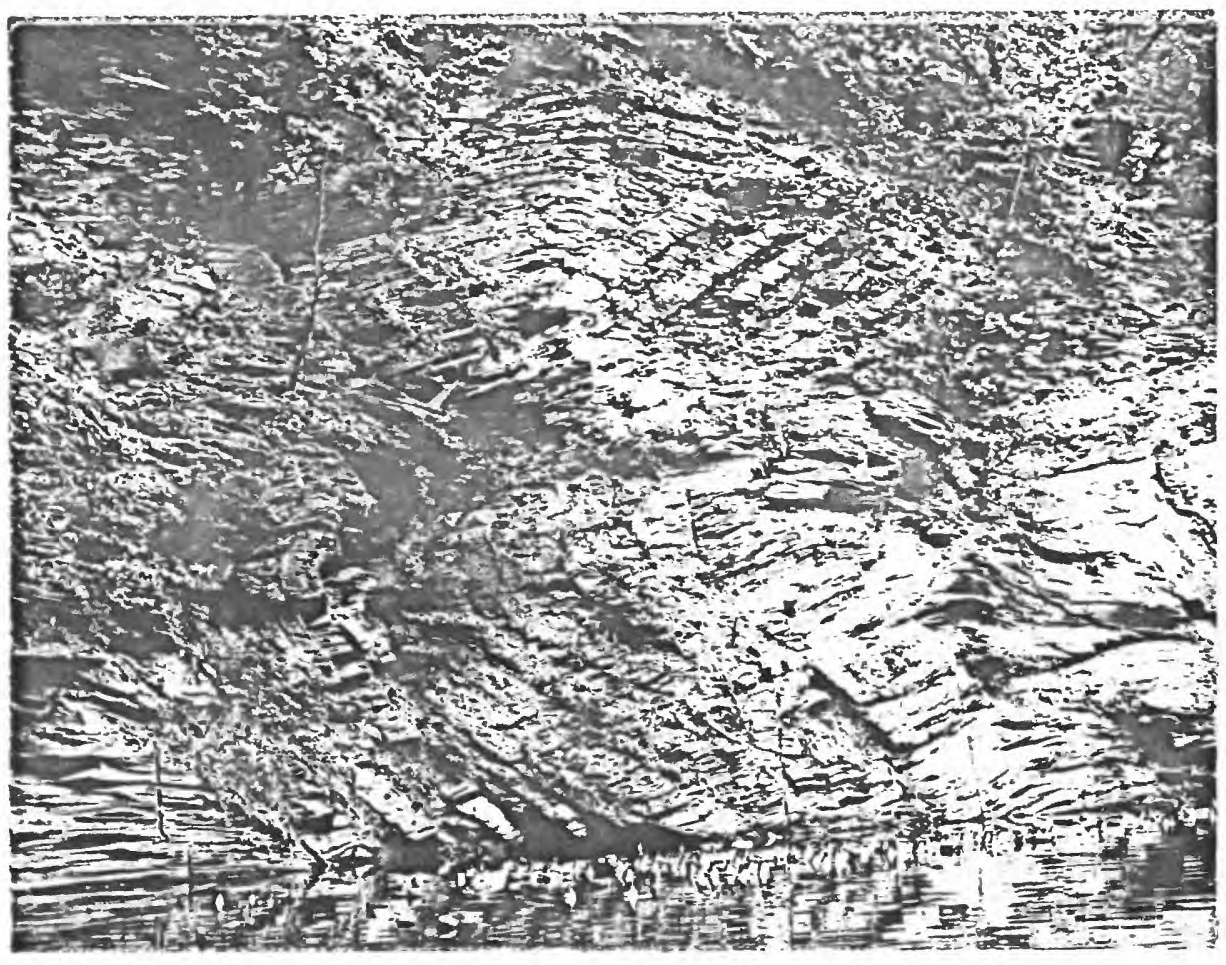

Figure 65. Nearly recumbent West Bangor syncline in the Strunk quarry, Pen Argyl Hember of the Martinsourg Formation. Slaty cleavage dips gently southeast ( $l \in f t$ ). This is an example of passive flow in lithotectonic unit 1 . Beer bottles in flooded quarry give scale. Note refraction of cleavage in siltier beds. 


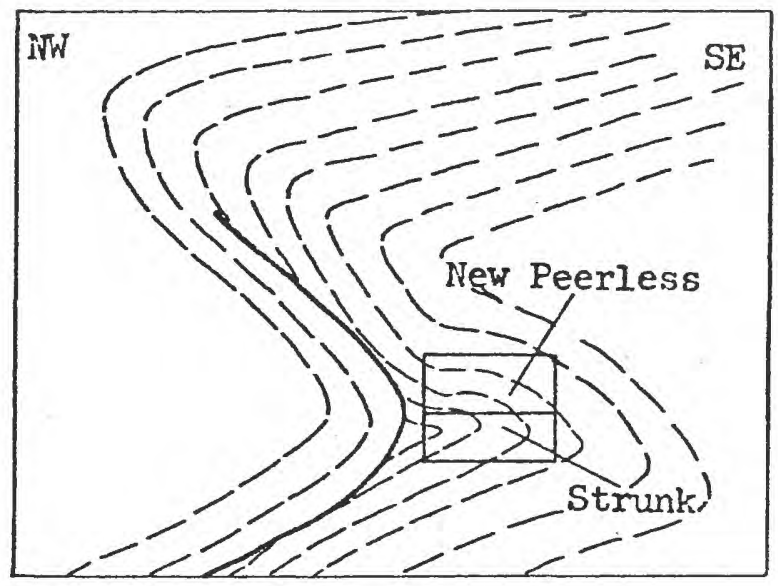

Figure 66. Diagrammatic section showing the structural position of the New Peerless and Strunk quarries. Dashed lines are bedding. The bedding-slip fault described by Behre (1933, p. 167) is shown as a solid line. 
and $13^{\circ} \mathrm{SE}$. The upper $1 \mathrm{mb}$ is more severely deformed and in the New Peerless quarry bedding and clearage are about parallel, showing that this part of the fold is essentially isoclinal in places. Several minor cleavage arches wero seen, but attitudes were difficult to obtain. One, however, in a swall pit about 300 feet south of the Hew Peerless quarry, plunges $13^{\circ} \mathrm{S} .45^{\circ} \mathrm{E}$. (fig. 64). The arch is broken by a mall fault, the attitude of whose plane is warped but is essentially N. $10^{\circ}$ E., $15^{\circ}$ SE. (fig. 67).

Behre (1933, p. 166, 167, 205, 206) iliustrates and de8cribes a bedding-silp fault in the New Peerless quarry. This fault was not seen because the querry is flooded, but similar structures have been seen in active quarries adfacent to the Stroudsburg quadrangle. The faults generally are parallel to folded beds to the northrest and truncate more tightly folded beds to the southeast (see fig. 66). They apparently developed during later phases of deformation as a method of relleving excessive stress in the tightening folds. Cleavgge is often warped at the fault contact and a second slip cleavage may have formed that is parallel to the axial planes of these small clearage folds.

The West Bangor syncline extends to the southwest where it is exposed in the Bangor Fidelity and West Bangor quarries (no. 1). It is less tight in that direction. Little Bangor quarry (8)

This small quarry has been filled in and no data could be tained. Behre (1933, p. 205) reports that bedding and cleavage 


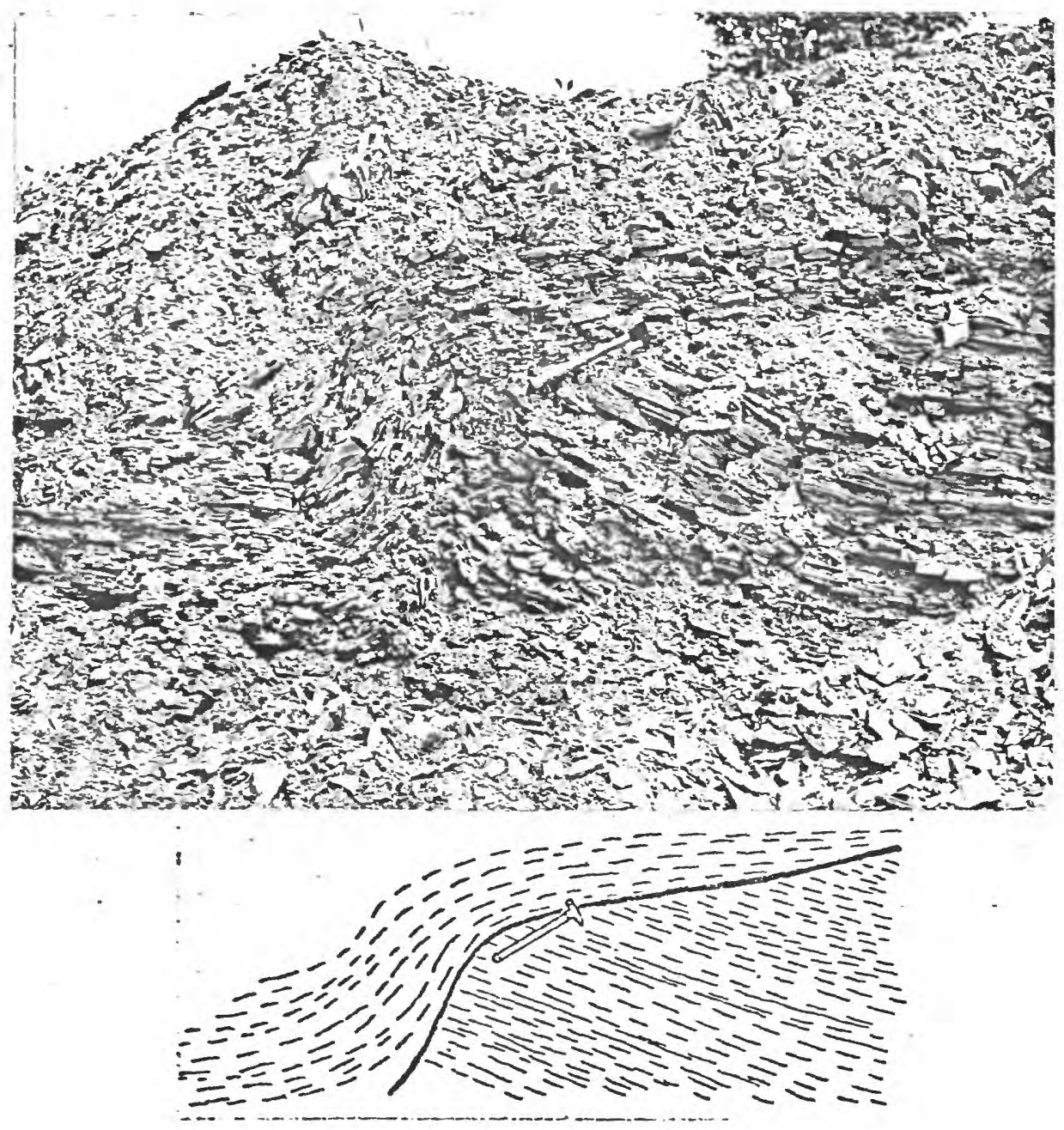

Figure 67. Photograph and sketch of minor clesvage arch and small fault in a borrow pit, about 300 feet south of New Peerless quarry. A thin gouge is present in the fault plane. Bedding and cleavage are subparallel. View looking scutheast. Exposure has been removed aince photograph was taken. 
are about parallel and dip gently southward. The beds are, therefore, on the upper limb of the overturned West Bangor syncline described in the New Peerless and Strank quarries. Mountain View quarry (9a)

This square quary is alightly more than 100 feet on a side. About 15 feet of slate is exposed above water. Dumps lie east of the openirg. Beds of slate with a few thin silty intercalations dip gently to the southwest and are, therefore, near the trough or in the gently dipping upright limb of the Old Bengor syncline (p1. II, section B-B').

Quarry (9b)

This shallow rectangular opening lies 600 feet south of the Mountain View quarry. It is 150 feet Iong, 90 feet ride, and about 5 feet deep. About 4 feet of till overlle the bedrock. The low dumps are 200 feet to the southerst. Bedding dips northestward between $12^{\circ}$ and $17^{\circ}$ and cleavage dips between $10^{\circ}$ and $20^{\circ}$ nearly due south.

Quarry (9c)

Slate of comercial quality was probably not obtained from this small digging because of the presence of several thin massive graywacke beds. The opening 1850 feet $10 n g$ and 25 feet wide and is located fust east of the dumps of quarry no. 9b. Bedding dips gently to the northest.

Quarry (10)

This nameless water-fllled quary 18 located in a small woods 
the center of a cultivated field and is approximately 60 feet long and 30 feet wide. Bedding dips gently to the northrest, as it does in this general area, and cleavage dips $2^{\circ} \mathrm{SE}$. in slate, but is refracted to $30^{\circ}$ in a 10-inch-thick calcareous grayracke. Shimer quarry (11)

About 15 feet of slate is exposed in the northern half of this quarry and approximately 5 feet of till overlies the slate. The beds dip gently northwestward (fig. 68), Behre (1933, p. 208) reported that it was at least 100 feet deep. Consolidated No. 3 quarry (12)

This quarry is irregular in shape and its flooded portions are separated by dumps (fig. 68). It is about 700 feet long. Drumps rise more than 100 feet above water level. The southern part of the opening presently cerves as the garbage dump for the town of East Bangor. Till ranges in thickness from 3 feet at the northern end to 8 feet on the western margin. The quarry was at least 100 feet deep (Behre, 1933, p. 207). Bedrock consists of thinly interbedded slate and siltstone. Some of the siltstone beds are crossbedded, and one set indicates a current direction of N. $75^{\circ}$ E. Bedding-plane slickensides in the northeast part of the quarry indicate that the overriding beds moved to the northwest. In several places bedding is displaced about $1 / 100$ inch along slaty cleavage, showing some slip has occurred on cleavage. Bedding generally dips gently westward and sourhwestward, as it ches in the Consolidated No. 2 quarry (no. 13), showing that the 


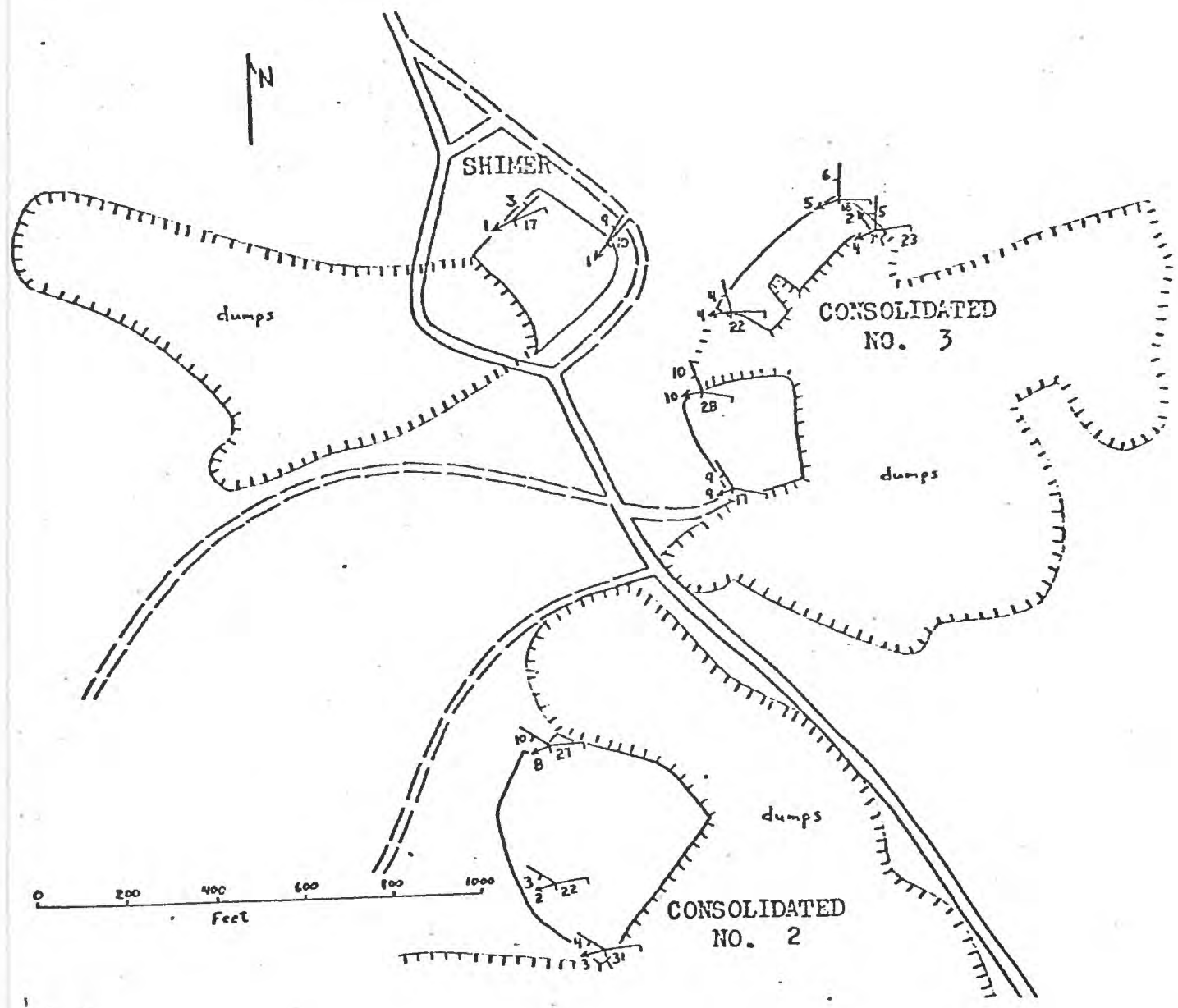

Figure 68. Geologic map of the Shimer, Consolidated No. 3, and Consolidated No. 2 slate quarries. See plate I for explanation of map symbols. 
qu Pies are in the brosd bottom of the overturned old Bangor syncline.

Consolldated No. 2 quisry (13)

This irregular opening is about 500 feet long. Dumps are more than 100 feet high on all borders except the west one. A maximum of 40 feet of rock is exposed sbove water in the northwest wall. Abont 5 feet of till overlies the slate. Slippage of bedding planes along cleavage shows the same type of northwest movement of overriding as in the Consolidated No. 3 quarry. Capitol Slate quarry (14)

This is the laxgest and only active slate quarry in the Stroudsburg quadrangle. It is listed by Behre (1933, p. 208-210) as the Consolidated No. 1-Star quarry. It is about 1,000 feet Iong and irregular in shape. The western part is presently being worked (fig. 69), and in 1961 it was about 250 feet deep, but continuing operations have made it deeper. Figure 70 is a detailed topographic and geologic map of the quarry showing the lajout of the operation. The quarry is located in the undulatory broad trough of an overturned southwest-plunging syncline whose axial trace Iles to the southeast (pl. I). Steepening northwest dips in the northeast corner of the opening indicate that the axis of the fold is not far away. Slippage along cleavage was observed in this quarry as in adjoining ones. Dumps completely surround the hole and are more than 100 feet high in places. Behre (1933, p. 209) noted the development of false (sIip) cleavage in the northwestern corner. This was not seen, but in the northern corner 


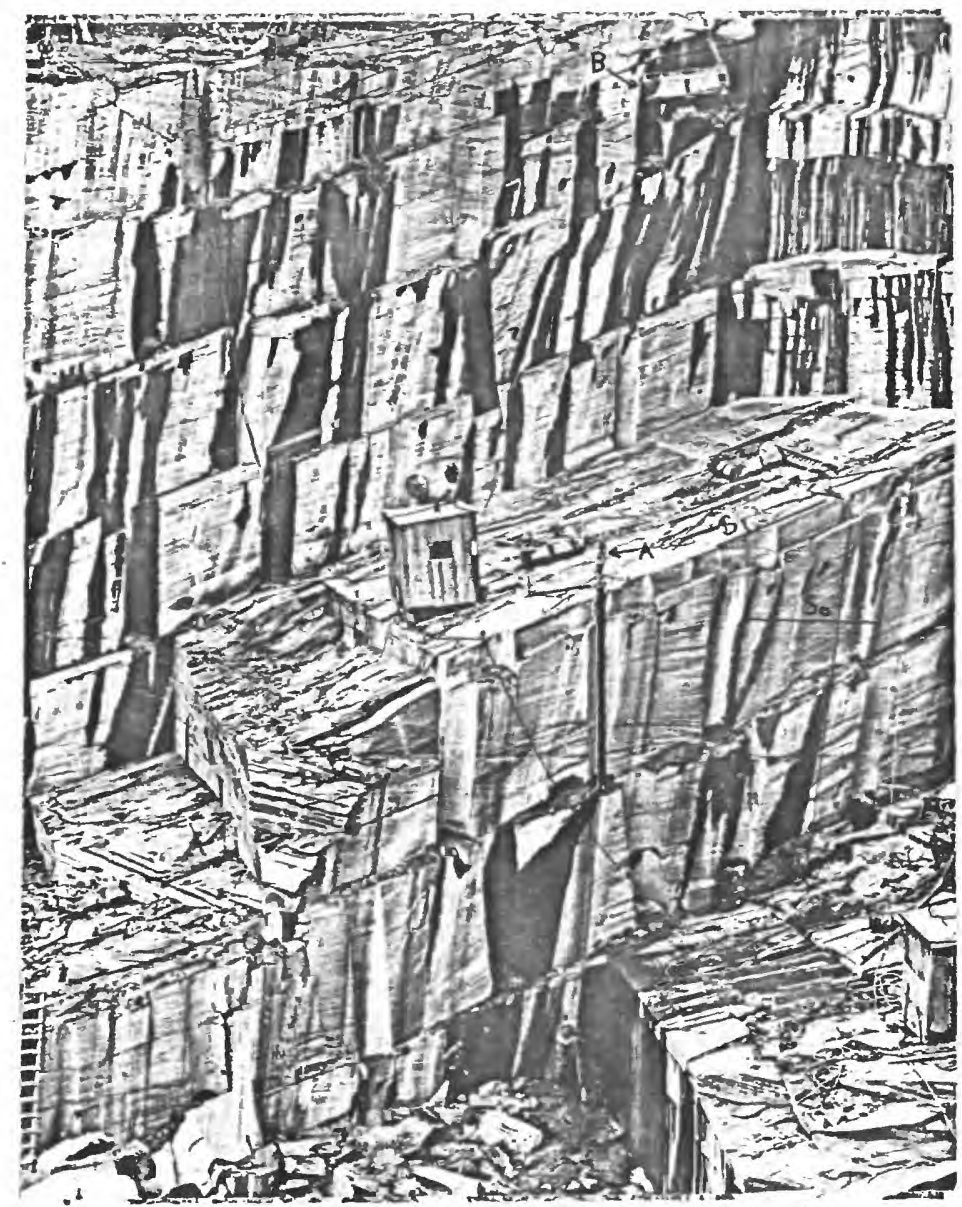

Figure 69. Operations in the northwest corner of the Capitol Slate quarry. Bedding $\left(\mathrm{S}_{\mathrm{O}}\right)$ dips gently northrest and cleavage $\left(\mathrm{S}_{1}\right)$ dips gently southeast. Intersection of bedding and cleavage, as seen on cleavage plane in center of photograph, approximates the trend and plunge of the fold axis. Note wire saw (at A) used to divide the quarry into large "pieces" from which blocks of slate are separated either manualiy (as man in bottorn is doing) or with dynamite. Bucket (at $B$ ) is being lowered to remove blocks of slate. The hole 1s more than 250 feet deep near this part of the quarry. The fairly thick beds of slate are typical of the upper part of the Ramseyburg Member of the lartinsburg Formation (see Pig. 3). 


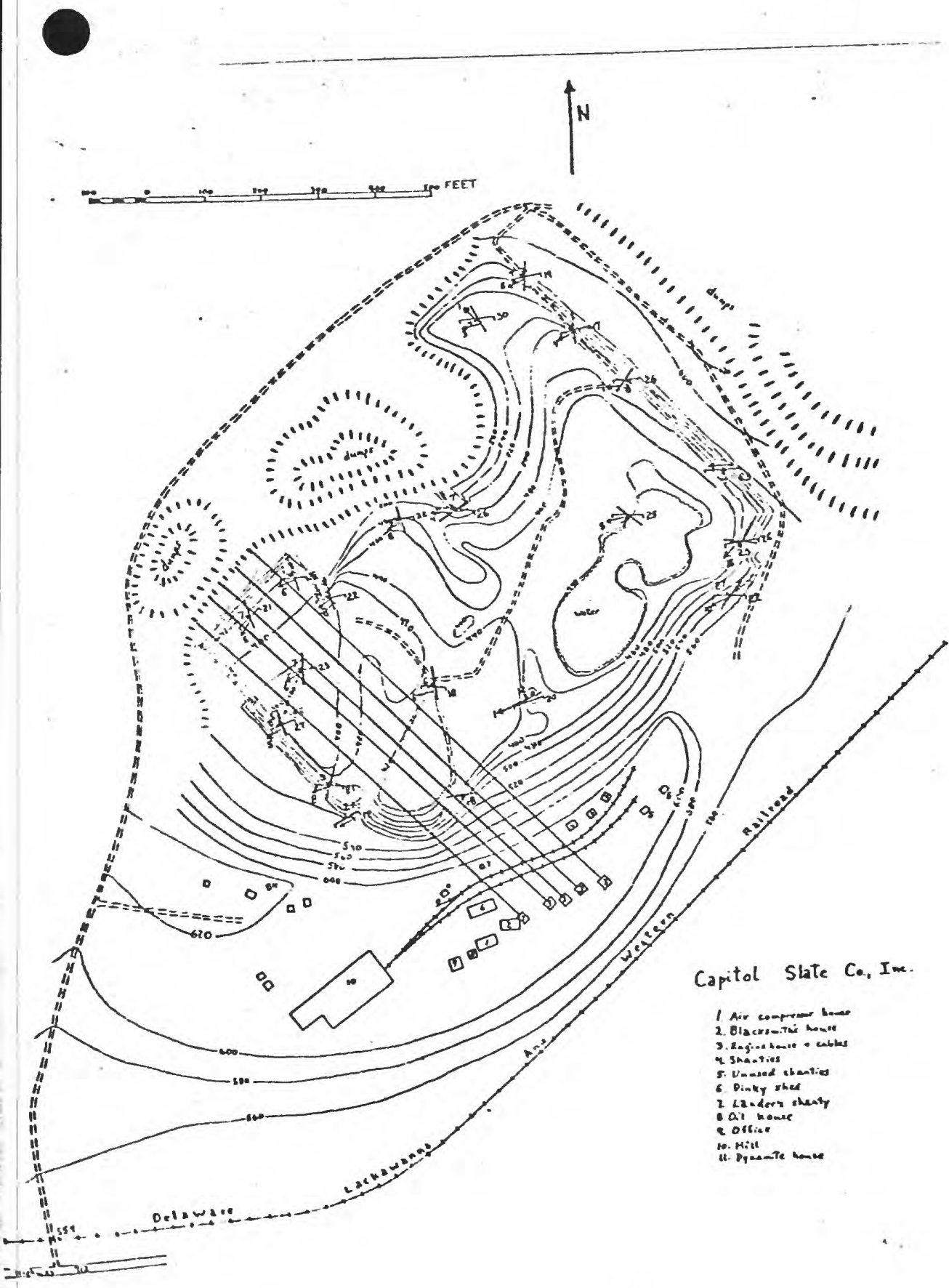

Flgure 70. Geologic and topographic map of the Capitol Slate quarry, East Bangor, Pa., showing plen of operations. 
the is a 5-inch-thick zone of quartz, calcite, and slate fragments parallel to bedding. Slickensides trend $\mathrm{N} .42^{\circ} \mathrm{W}$. showing that this is a bedajing-slip fault. Cleavage is crumpled in the zone but well-defined slip cleavage was not apparent. More than 25 feet of till overlie bedrock in the northeast corner of the quarry.

Standard quarry (15)

The Standard quarry lies 200 feet west of the Capitol quarry and shows similar structural trends. About 30 feet of slate is exposed above water, and about 10 feet of drift overlies the slate. The quarry is roughly circular and about 250 feet across. Bangor Valley (Bangor Eclipse) quarry (16)

About 50 feet of bedrock and 10 feet of drift are exposed in the northwest part of this quarry. Bedding dips gently northest. Bangor Central quarry (17)

This flooded rectangular opening is about 200 feet long. About 60 feet of slate and 20 feet of till are exposed in the northwest end. Bedding in the southwest corner is N. $36^{\circ} \mathrm{W} ., 4^{\circ} \mathrm{SW}$., but dips $13^{\circ} \mathrm{NW}$. in the northrest wall. Bangor Royal quarry (18)

This quarry now serves as the garbage dump for the town of Bangor and was, therefore, inaccessible. Attitudes shown on plate I were obtained by sighting across the quarry and are approximate. A few foundations and old rusted cables lie in the durn to the nh. Apparently this opening was also inaccessible to Behre (1933, p. 212). 
umbia Bangor, New Bangor, and Bangor Excelsior quarries (19)

The Columbia Bangor and New Bangor quarries are flooded and presently appear as a single opening 1,200 feet long and 300 feet wide. The Bangor Excelsior is an irregular opening about 500 feet long and separated from the New Bangor by a narrow wall of slate. Only the northern corner of the New Bangor is in the Stroudsburg quadrangle. The dumps to the east apparently served all three quarries and are about 200 feet high. Many.shanties, a furnace and engine house, and overhead cables still remain. The slate is covered by about 15 feet of glacial drift at the norib end.

The structure as deternined-from surface exposures (fig. 71) corroborates Behre's observations (1933, p. 212-214). Bedding in the northeast wall of the Colunbia Bangor quarry is overturned to the southeast. In a small exposure on the southeast wall of the quarry, bedding dips gently southwest on the crest of an overturned anticline. In the New Bangor and Bangor Excelsior quarries bedding is upright and dips to the northwest. The trend of intersection of bedding and cleavage (which approximates the trend of the fold axis) in the northeast wall of the Columbia Bangor quarry shows that the overturned limb plunges beneath the upright beds to the southwest, substantiating the fact that the quarry is opened in an overturned anticline. The axial plane of the fold dips gently southeast. Cleavage in the overturned limb is rotated to the southwest, as it is in the New Peerless and Strunk quarries dagcribed above. No second-generation slip cleavage was observed, 


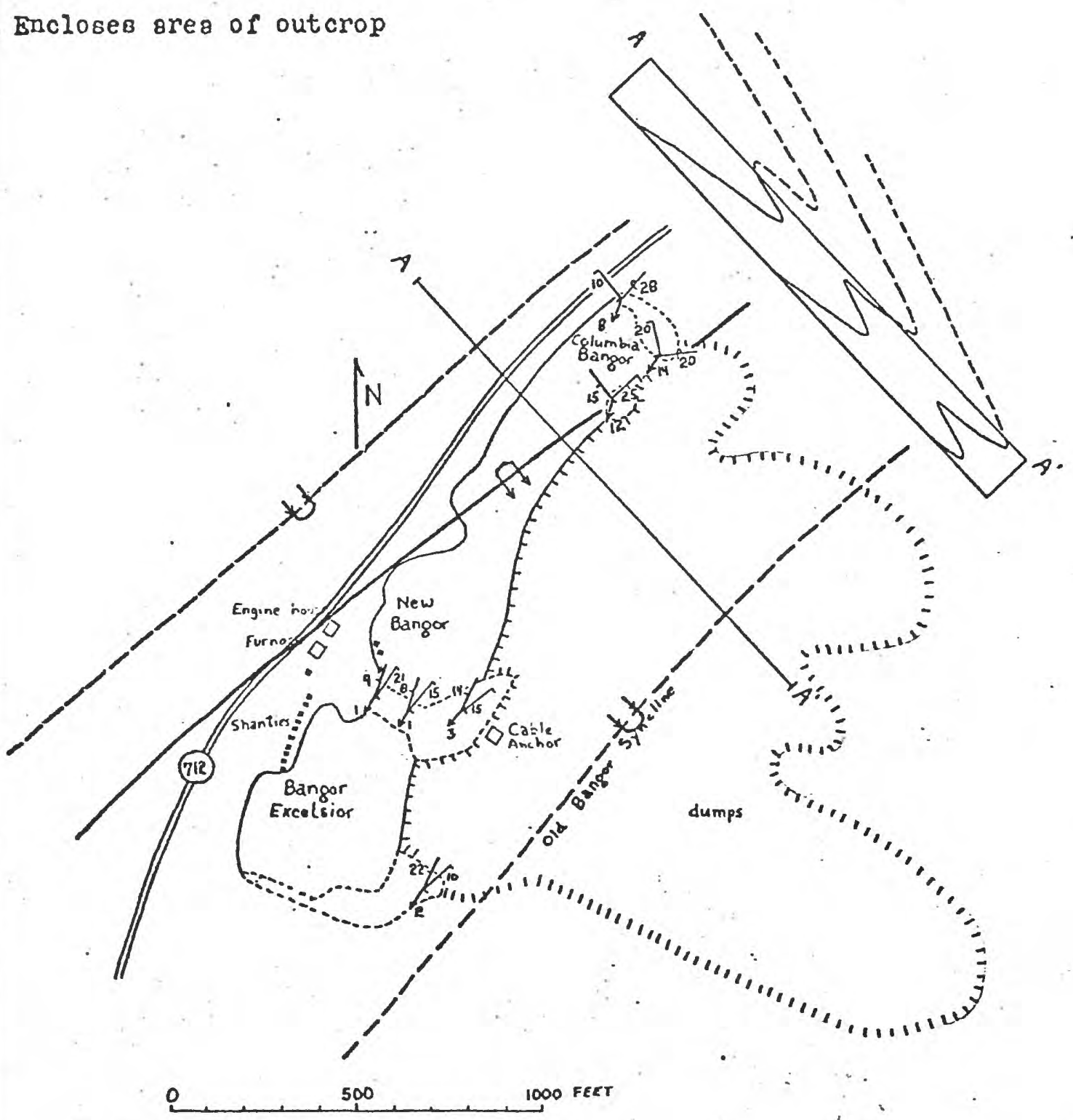

Figure 71. Geologic map and section of the Columbia Bangor, New Bangor, and Bangor Excelsior quarries, East Bangor, Pa. Map symbols are explained in plate $I$. 
bur contorted cleavage was seen in fragments on the dumps. An overturned symcline is inferred to lie to the northiest between the overturned limb of the anticline and the upright northwestdipping beds in the quarries immediately to the northwest. An over turned syncline, the Old Bangor symcline of Behre (1933, p. 214), is exposed in the 01d Bangor quarry 500 feet south of the Bangor Excelsior quarry. The inferred position of the axial trace of this fold in the Stroudsburg quadrangle is shom in figure 71 and plate I. Emory Pipher quarry (20)

Knom locally as the Enterprise, this quarry is located in a tributary of Slateford Creek. Most bedrock exposures are flooded, but small outcrops on the northwest side show bedding to dip $9^{\circ} \mathrm{SE}$. and cleavage to dip $22^{\circ} \mathrm{SE}$. A few thin grayracke beds were seen. Both bedding and cleavage are folded in a mall arch, over 10 feet across, winich trends S. $31^{\circ} \mathrm{W}$, and plunges about $1^{\circ} \mathrm{SW}$. Bedding on the northwest side of the $\operatorname{arch}$ is $\mathrm{N} .28^{\circ} \mathrm{E} ., 14^{\circ} \mathrm{NW}$. , and cleavage is N. $17^{\circ} \mathrm{E} ., 9^{\circ}$ NW. Dumps surrounding the quarry are about 20 feet high. The bedrock is overlain by a few feet of t111.

Quarry (21)

This small circular opening is about 40 feet wide. A small creek flows through it, and it is now the site of a reservoir for local water supply. Slate and some graywacke beds are exposed. liding is N. $44^{\circ} \mathrm{E} ., 22^{\circ} \mathrm{NW} .3$ cleavage is N. $84^{\circ} \mathrm{E}, 11^{\circ} \mathrm{SE}$, with 
sight variation. Of particular interest is the divergence in strike between these beds and beds in the Shakangunk Fomation Inunediately to the north. Washington Brown quarry (22)

In this 100-foot long oval-shaped opening about 8 feet of alate and interbedded graywacke are exposed. In the southeast corner bedding strikes N. $31^{\circ}$ E. and dips $20^{\circ} \mathrm{NW}$. The attitude of cleavage is $\mathrm{N} .12^{\circ} \mathrm{W}, 14^{\circ} \mathrm{SW}$. This is part of an apparent cleavage arch with cleavage dipping to the northrest as the contact wth the Shawangunk Formation is approsched (see pl. I). Sanders (in Lesley and others, 1883, p. 86) referred to this opening as the John Morrison's quarry. The Washington Brown quarry, accordIng to Prime, is the small opening 2,600 feet northeast of this quarry in the Portland quadrangle (no. 23). Quarry (23)

This quarry is about 200 feet above Delaware River. It is square, 100 feet on a side, and about 40 feet deep. Bedding dips moderately to the northwest and cleavage dips in the same direction at a gentler angle. Bedding, however, is not overturned as will be discussed later.

Williams quarry (24)

This quarry is located in Slateford Creek and is about 600 feet long. At the western end the creek falls over the 80 -foothigh wall of the quarry and at the eastern end it flows betwoen foot-high walls of slate that are 10 feet apart. Approximately 
feet of drift overlie the slate. The slate is underlain by a massive 20-foot-thick unit of grayracke sandstone and siltstone and 50 feet of interbedded slate and grayracke that is exposed 1,500 feet downstream. The slates in the quarry are also overlain by grayrackes to the northrest showing that the quary is in the Ramseyburg Member of the Martinsburg Formation (see discussion on p. 8 and 9). Bedding fairly constant in the quarry, but the dip of cleavage changes from $11^{\circ} \mathrm{SW}$. In the eastern end to $44^{\circ} \mathrm{SE}$. in the western end. In the southwest corner of the opening, about 2 inches of quartz is found in a slickensided zone parallel to bedding. Microscarps indicate that the overlying beds moved N. $53^{\circ}$ W. Srall crenulations in the zone whose axes trend perpendicular to the slickensides were also produced by this movement. Snowdon quarry (25)

This is an irregular opening about 500 feet long and 300 feet wide. About 40 feet of slate and some graywacke is exposed above water. Operations began about 1870 and discontinued about 1920 (Behre, 1933, p. 199). About- 15 feet of till overlies the slate in the northwest part of the quarry, and beds on both sides are overturned (fig. 72). The fault is actually a shear zone about 50 feet wide in which slaty cleavage is folded and a second (slip) cleavage has developed (fig. 73). Dump blocks have bedding-plane slickensides deformed by slaty cleavage indicating that flexural slip preceded passive flow which was in turn followed by fanlting d the development of slip clearage. The quarry is discussed 


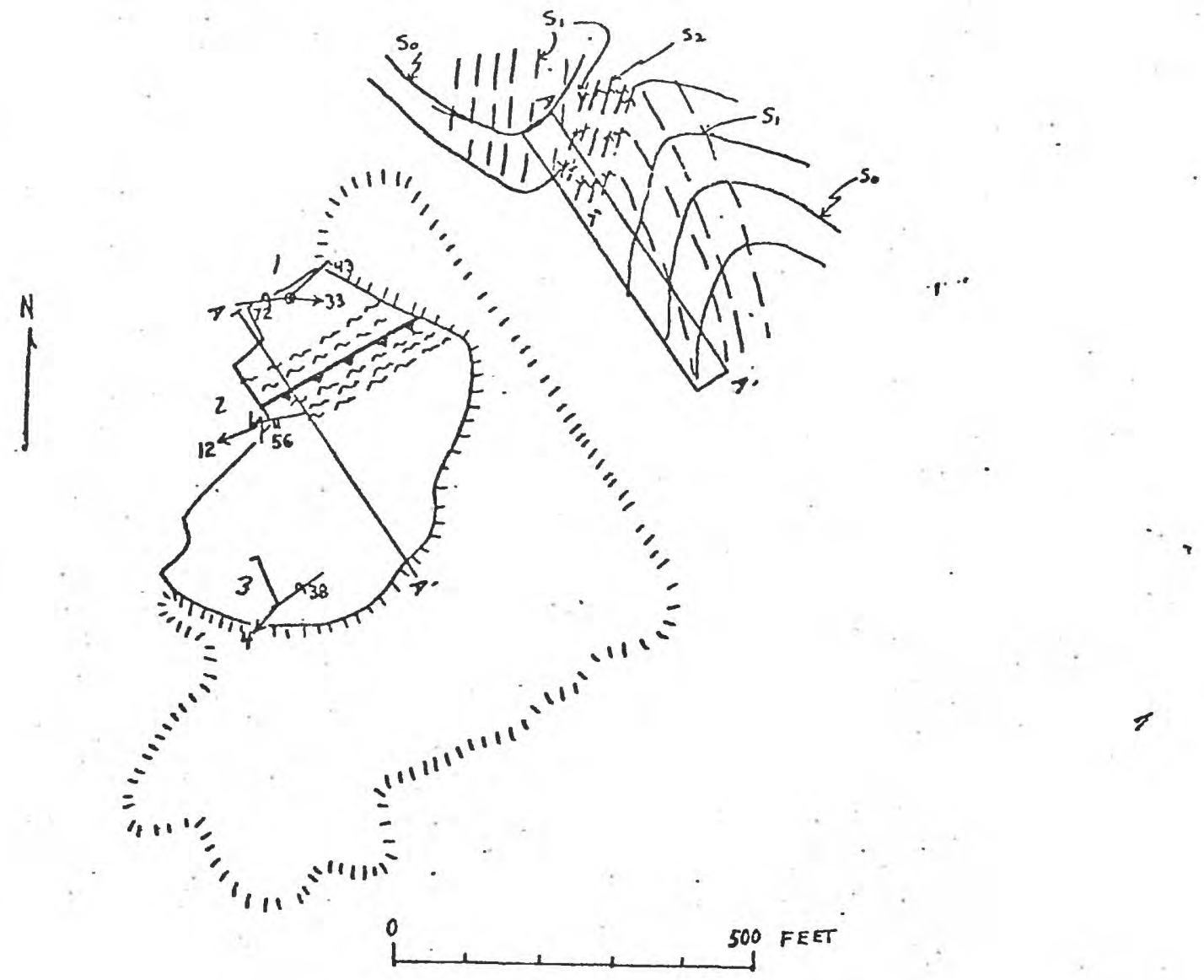

\section{EXPLANATION}

$A_{38}$ Strike and dip of overturned bedding $\left(S_{0}\right)$

4. Strike and dip of slaty cleavage $\left(s_{1}\right)$

$\pi_{56}$ Strike and dip of slip cleavage $\left(S_{2}\right)$

$\rightarrow \rightarrow_{3}$ Intersection of bedding $\left(S_{0}\right)$ and slaty cleavage $\left(S_{1}\right)$

in Minor cleavage crinkle showing style and plunge

or Thrust fault, sawteeth on upper plate

$\therefore \approx \approx \approx$ Shear zone, much calcite and quartz, slip cleavage developed '

Fleure 72. Geologic map and section of the Snowdon slate quarry. 


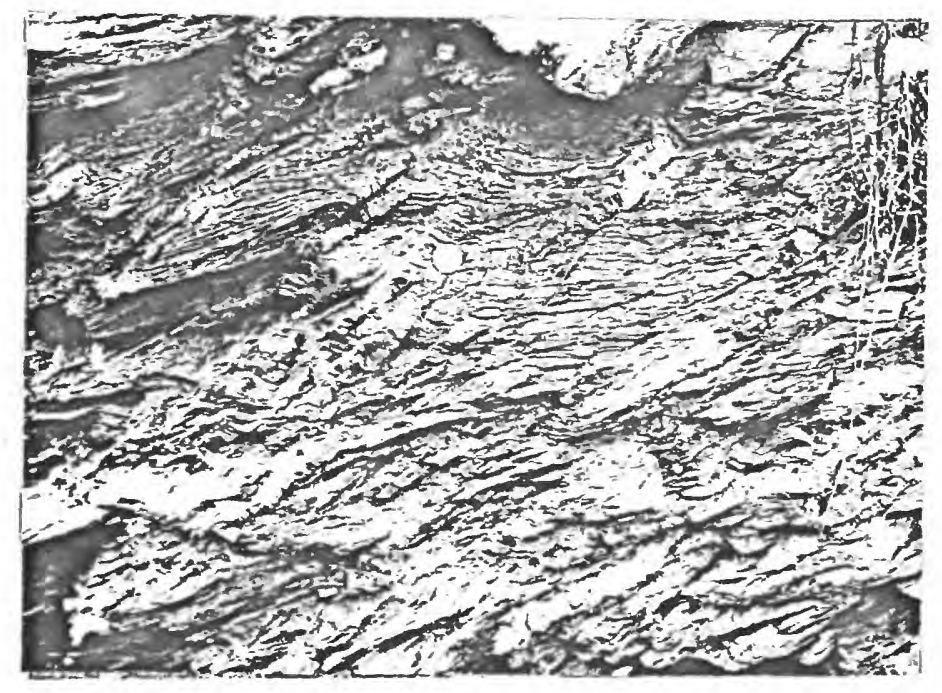

Figure 73. Slip cleavage in Snowdon quarry (no. 25) dipping steeply to the southeast (left) deforming nearly horizontal slaty cleavage. These megascopic features have been called shear zones by Behre (1933, p. 37) and are equivalent to his sualler scale false cleavage (slip cleavage of this report). 
anders (in Lesley and others, 1883, p. 88-89) who reported that the quarry was 150 feet deep. Evidently, slate was obtained from beds south of the fault zone. Frye quarry (26)

The Frye quarry is about 400 feet long and has a maximum width of about 75 feet. It has a maximum depth of about 20 feet and is cut into arenaceous and carbonaceous slates. No machinery is present and large trees in the bottam indicate that it has not been worked for many decades. The northwest section was probably worked for slate because a fault is close to and parallels the southeast wall (fig. 74). The fault zone has a l-inch-thick gouge but is fairly smooth. Humerous quartz-filled tension fractures are near the fault. The rock is deeply weathered in places so that bedding and cleavage are indistinct.

Quarry (27)

This is a small opening about 25 feet long and 15 feet deep. Drmps lie to the east and west. Cleavage is N. $35^{\circ} \mathrm{E}$., $32^{\circ} \mathrm{SE}$, and bedding dips $7^{\circ} \mathrm{SW}$. Thus, the quarry is on the upper limb of a southwest-plunging fold (see section F-F'-F', pl. II). Quarry (28)

This is an overgrown quarry cut into the Bushkill Meraber of the Martinsburg Formation on the southwest bank of the Delaware River about 300 feet west of U.S. Highway 611A. It is about 100 feet long and as much as 75 feet wide. About 25 feet of slate is posed on the uphill side overlain by about 10 feet of glacial 


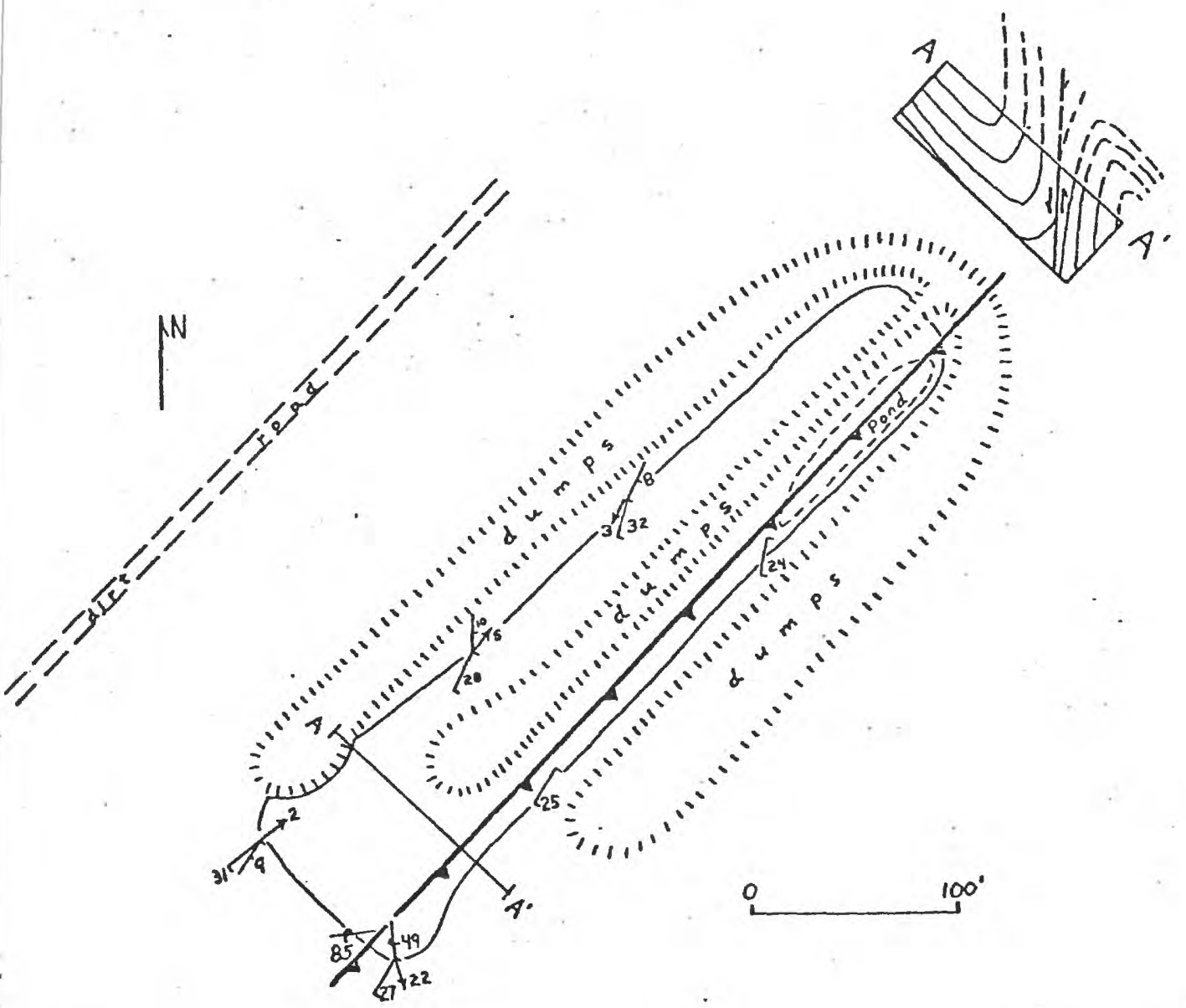

Figure 74. Geologic map and section of the Frye quarry. See plate I for explanation of map symbols. 
drift. The duraps extend along the southeast side of the quarry to the highway, paralleling the creek that flows through the quarry. Bedding and cleavage dip to the northeast, possibly rotated to that position along a concesled fault nearby. There Is a fault about 400 feet to the north. A dense, dark-gray to medlurn-dark-gray, very fine grained quartzose, micaceous, and chloritic dolanite concretion about 4 feet long and 2 feet wide was found near the botton of the quarry. It is flattened paraIlel to bedding and cleavsge maps around it.

New Jersey quarry (29)

The early history of this quarry is given by Cook (1868, p. 519) and Chance (in Lesley and others, 1883, p. 149-15I). The quarry is aneven in plan, about 500 feet Iong and 250 feet ride. A creek falls over a 75-foot wall of slate at the northeast end and flows out to the southwest. The dumps extend for about 1,000 feet to the southwest opening along the creek. No thick graywacke beds were seen. Abcut 20 feet of glacial deposits overlie the slate. Bedding and cleavage remain fairly constant. Cleavage attitudes are N. $53^{\circ}-73^{\circ}$ E., $12^{\circ}-25^{\circ} \mathrm{SE}$; bedding is N. $38^{\circ}-47^{\circ} \mathrm{E}$, $26^{\circ}-44^{\circ} \mathrm{NW}$. The becis clearly strike into the Shawangunk Formation. Some movement along bedding is shown by slickensides. Quarry (30)

This small quarry is mentioned by Chance (in Lesley and others, 1883, p. 148). It is about 100 feet long, 40 feet deep, and is cated in a small ravine about 200 feet above Delaware River. 
About 60 feet of interbedded slate and graywacke is exposed. Graywacke occurs in thick massive beds and is most abundant near the top. Bedding strikes N. $53^{\circ}$ E. and dips between $19^{\circ}$ and $30^{\circ} \mathrm{NW}$. Cleavage dips gently to the northrest, varying between $2^{\circ}$ and $15^{\circ}$. Dumps extend dom the hillside for about 300 feet on both sides of the quarry. This opening is of interest because of the near parallelism of bedding with that of the overlying Shawangunk, a departure from trends in the Martinsburg to the south in New Jersey and southwest in Pennsylvania, and because of the thick graywacke beds showing the proximity of the middle member of the Martinsburg Formation (Ramseyburg Member) to the Shawangunk Formation in New Jersey.

\section{Lithotectonic Onit 2}

The Shawangunk Fornation and Bloomsburg Red Beds comprise this lithotectonic untt. In general, folds are more upright and open than those folds in the Martinsburg about 1 mile or more southeast of the Shawangunk-Martinsburg contact. Some folds are tighter, however, such as the Little offset anticline and Poplar Valley syncline, in places. The geometry 83 shown in the cross sections, plate II, may not be exact because of poor exposures due to thick drift cover, and some of these tight folds may be faulted. If 80 , the displacement is not great. The limited exposures can be interpreted to suggest that faulting is not necessary to explain the structural relations. The fold axes in this unit are interpreted to extend into the Martinsburg terrane, although there 
is no definitive evidence of this in the quadrangle. However, in the Bushkill quadrangle, 5 miles to the northeast, the Dunnfield syncline and Cherry Valley anticline extend into the Martinsburg and beds in the Martinsburg are folded concordantly with the overlyling Shawangunk, except for slight divergence in dip between the two formations due to the Taconic angular unconformity. All of the folds plunge gently to the southwest. There is generglly good topographic expression on the folds on Blue and Kittatinny Mountains. They also show up well on aerial photographs. Outcrops are very poor southwest of the Wisconsin terminal moraine at the Little Offset, especlally on the broad top of Kittatinny Hountain north of Big Offset, but the folds can be traced with a fair degree of confidence by using photographs and the topographic map. The Big and Little Offsets are topographic expressions of the Big Offset syncline and Ross Cormon Creek symcline, respectively.

The monoclinal dip of the Shatangunk Forration on the southeast limb of the Dunnfield Creek syncline is broken by a few small folds and faults (see figs. 21, 75). The small fold seen in figure 21 is shown in detail and described in figure 76. A small thrust fault subparallel to bedding and a fold above the fault were seen about 50 feet above the fold and fault shown in figure 76. Drag in bedding along the small fault shows that the overriding limb nored domward to the northwest, an oppsoite sense of movement to that generally envisioned for "drag" towards the crest an anticline. These folds are thus incongruent and are also 


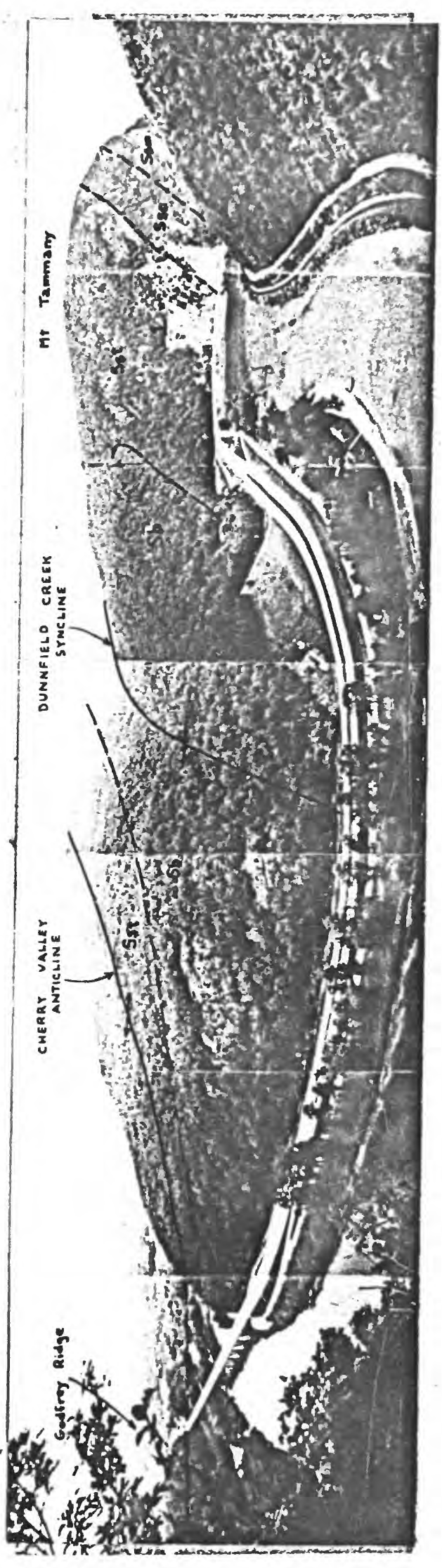

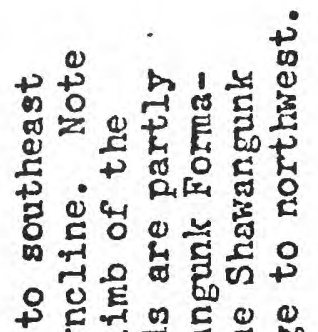

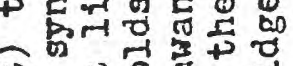

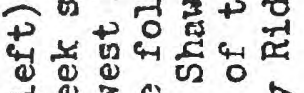

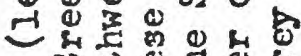
声运出

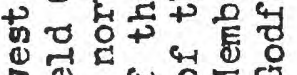
है क 50

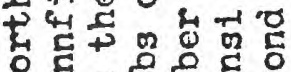

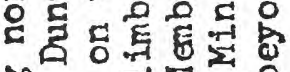

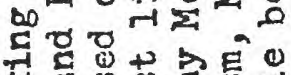

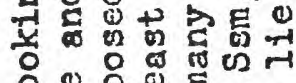
연 Ð

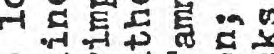

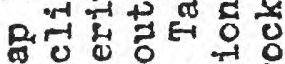
可 0 D

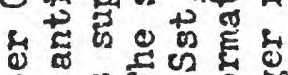

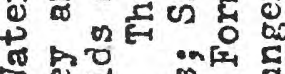
₹ 0 क्षा की

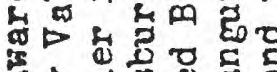
ज न ๑

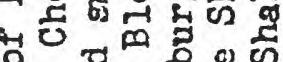
○

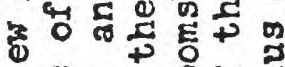

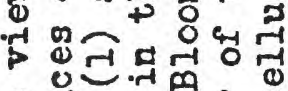

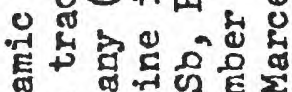

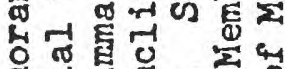
O

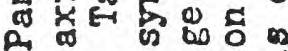

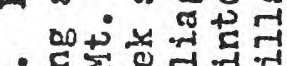

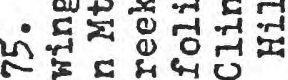
एव हु.

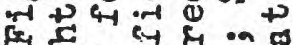
कo 500

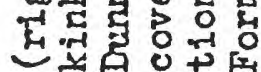




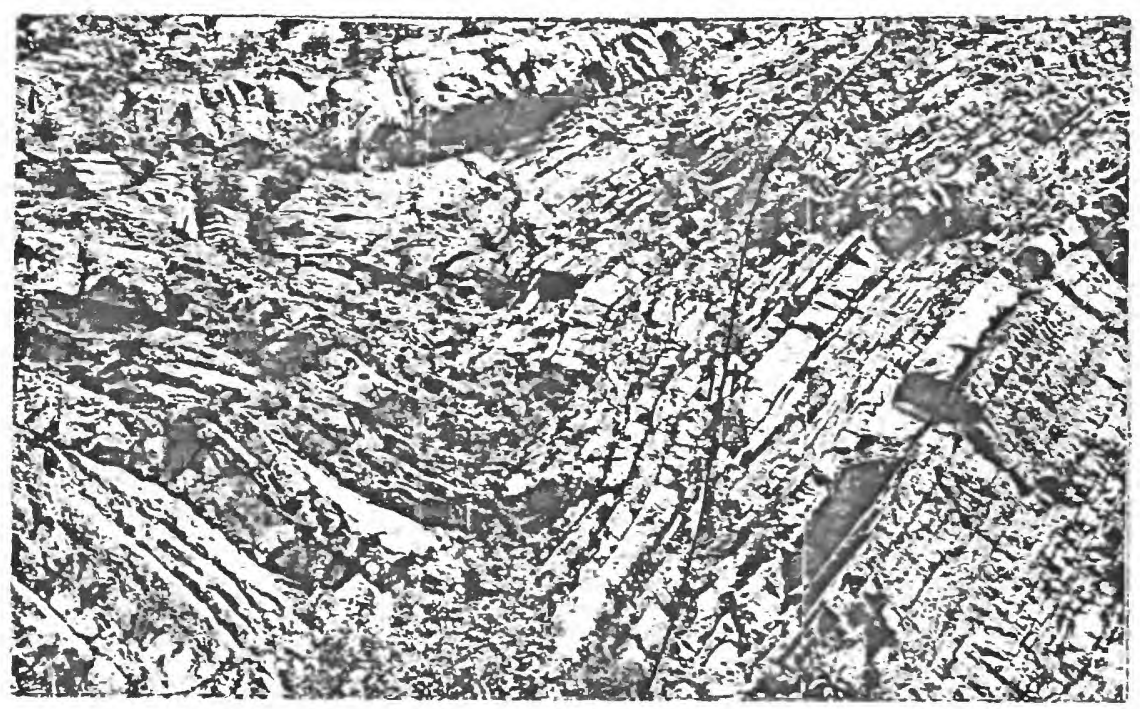

Figure 76. Fold and thrust fault in the Clinton Member of the Shawangunk Formation at Delaware Water Gap, N.J. The strike of the fault parallels local structural trends. The fault dips steepIy to the northwest (left) at the botton and dies out upward into a bedding plane. The sense of movement is shown by drag on the upper plate. Note crumpling of beds in the center of the syncline near the top of the fold. 
disharmonic with beds above and below. Most bedding-plane slickensides indicate that the sense of movement of overriding beds was to the northwest. Thus, it is believed that these folds and faults developed after folding began by northwest movement, perhaps under the influence of gravity. By analyzing deformation lamellae in the fold shown in figure 76, scott and others (1965) concluded that the lamellae formed early in deformation and were externally rotated during the later stages of folding. The deformation in lithotectonic unit 2 was, therefore, not simple, 83 will be mentioned again.

About 600 feet north of the structures shown in figure 76 is a structural terrace, 50 feet wide, with beds that dip gently southeastward interrupting the northwest homoclinal dip in conglomerates and quartzites of the Tammany Member of the Shawangunk Formation. The fold produced is similar (the fold form extends upwards for 500 feet unchanged) and the axial planes dip ateeply southeastward. Faill (1969, fig. 2) describes it as a kink band, but perhaps that term ought to be reserved for microscopic and small-scale (hand sample) features. The terrace formed by flexural slip because bedding-plane slickensides are present, and there is no apparent change in thickness of beds in different parts of the fold. I do not believe that the major folds in this lithotectonic unit can be ascribed to kink-folding--the crests and troughs are not abrupt enough and the limbs are not generally Mraight sided (pls. II, III). However, lithotectonic unit 3 may 
have deformed by kinking and the structural geometry may meet the qualifications for that process.

The Kemmerervilie anticline rises from the western part of the Stroudsburg quadrangle and extends to Delaware Water Gap where it dies out and is traced into a series of smaller folds (p1. I). Willard (1938) believed that the anticline is the major structure in the Bloomsburg Red Beds in the gap and that the anticline is broken by a number of high-angle normal faults. No such faults occur, and the major structure at Delaware Water Gap is a complexly folded syncline (Dunnfield Creek syncline) or, assuming the northwest limb to be nearly flat, a structural terrace (see cross section F-F'-FH, pl. II, and fig. 75). The small folds superimposed on the Dunnfield Creek syncline in the Blocmsburg Red Beds average a few hundred feet in wavelength, they have amplitudes generally less than 40 feet, and can be traced for about $1 \mathrm{mile}$ along the length of their axes. Bedding-plane slickensides are abundant and small steps or microscarps on them clearly indicate that translation of overriding beds was to the northwest in all parts of the folds. This northwest movement is corroborated by numerous wedges that are mall imbricate shears from sole beddingplane slips (fig. 77). Cleavage dips southeast in all parts of the fold and would appear to have formed after the small-scale folding, except that the cleavage is dragged at many bedding-slip surfaces. By rotating bedding back to horizontal in the fold that partly shown in figure 77 , it was found that cleavage was not 


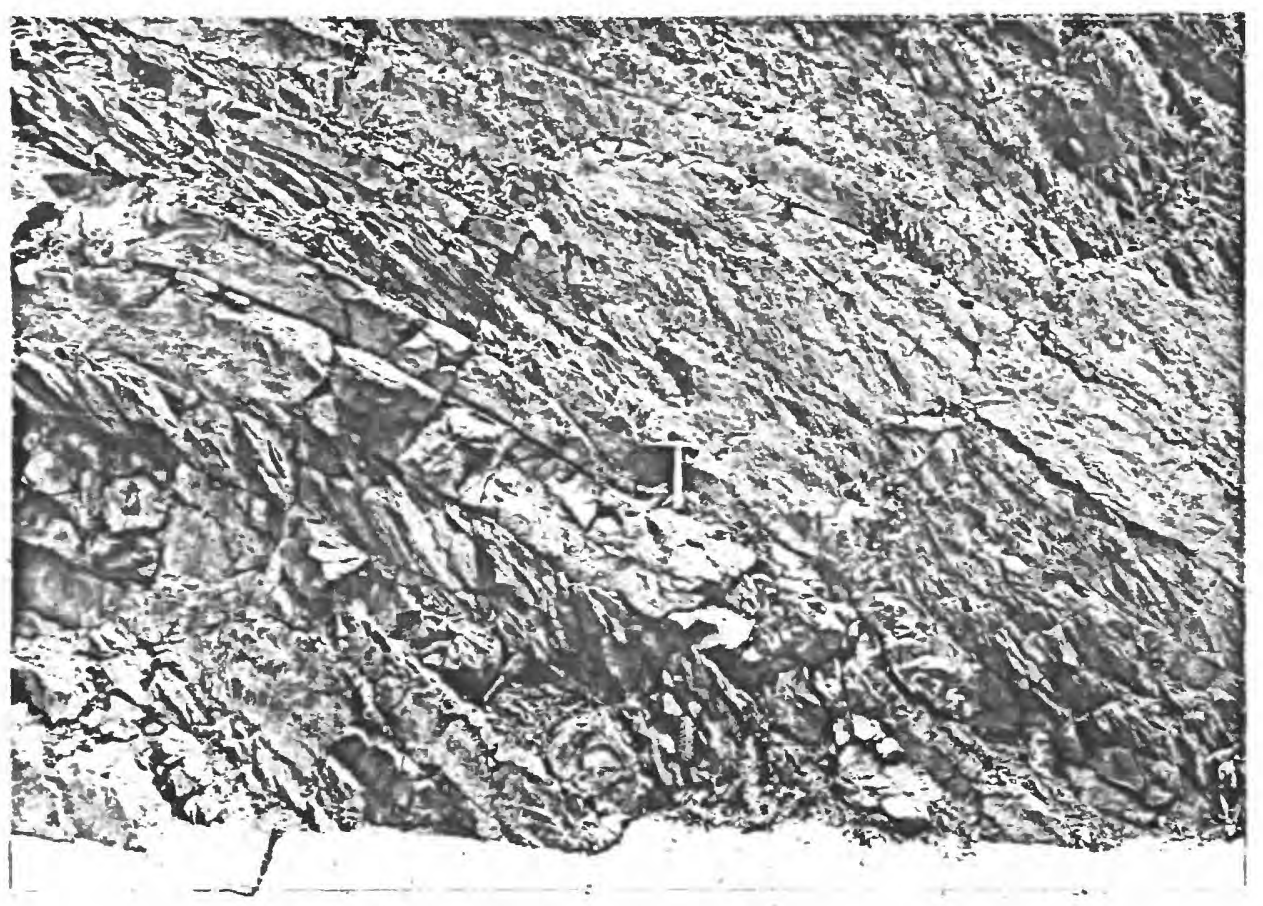

Figure 77. Wedging and bedding-plane slip in the Bloomsburg Red Beds, just east of where U.S. Interstate Highway 80 crosses Delaware River, Delaware Water Cap, N.J. The bedding plane at bottom of hammer handle is slickensided and microscarps indicate northwest movement of overriding beds. Wedge lies to left of harmer. Note southeast-dipping (to left) cleavage in silty beds. The sigmoidal shape of the en echelon tension fractures are probably not due to frictional drag but to rotation during continued movement indicated by the wedge. The movement picture is corroborated by the orientation of the fractures (for example, see Shainin, 1950). The cleavage is perpendicular to the last-formed part of the tension crack, thus also perpendicular to maximum compressive stress. 
rotated back to parallel orientations in all parts of the fold. Thus, the cleavage did not simply develop prior to folding and later become rotated to its present position during folding. As mentioned previously, the deformational pattern in lithotectonic unit 2 is far fron simple, and folding, cleavage development, bedding-plane slippege, and wedging were probably overlapping features. Maxwell (1962, fig. 9) showed some of these structures and claimed that the cleavage is a fracture cleavage that developed by interbed shear. But, as will be discussed later, there is some mineral alignment along cleavage planes. The cleavage in the Bloonsburg parallels the cleavage developed regionally.

The relative ages of the structures in the Bloomsburg at Delaware Water Gap seem to be (1) uplift and start of folding of the Dunnfield Creek syncline, possibly accompanied by the initiation of cleavage development; (2) northwest sliding of beds into the broad trough and onto the northwest limb of the symcline forming mall folds with superposition of the regional cleavage on the folds; (3) continued bedding-slip and wedging draging cleavage at the bedding-slip surfaces and shearing off the tops of several anticlines (as pictured by Maxkell, 1962, fig. 9, for example). These features probably developed during one continuous period of deformation and their order may have varied from place to place due to differences in local stress conditions. The accumulated displacement (net telescoping) of the bedding slips and wedges may amount to thousands of feet or more. 


\section{IIthotectonic Unit 3}

The structure in lithotectonic unit 3 is too complex to be shown on the quadrangle map (pl. I) in detail, and a larger scale map is presented for this purpose (pl. III). The folds, in general, are smaller than in other units (fig. 78). They are overturned or asymmetrical to the northwest, en echelon, and the plunge is variable so that when viewed perpendicular to axial traces, they appear to be crossfolded (fig. 79). The variability in plunge may be due to convergence and divergence in the moving rock mass parallel to the b-tectonic axis, which, in turn, is due to differential foward motion of the northwestward-migrating mass. The difference in amount of shortening between rocks in 1ithotectonic unit 3 as compared to rocks in lithotectonic unit 2 is more than 15 percent, If all the complex folding shown on plate I was by flexural slip. However, some of the folding was passive, so the net difference In shortening is somewhat less than 15 percent. In sone folds beds in argillaceous stratigraphic units, such as the Port Eken Shale shown in figure 35, are thickened as much as 50 percent in the hinge areas relative to the limbs. In most cases cleavage fans In the folds open toward fold troughs (convergent fanning, fig. 78), but in others the cleavage fan is divergent ( $\mathrm{fig} .80$ ). In the Slater-Canfield quarry, 1,200 feet west of where $0 . S$. Interstate 80 crosses Brodhead Creek in the northeast part of the Stroudsburg quadrangle (labeled "gravel pit" on the topographic map), crumpling In the core of an overturned syncline has produced reversed foldIng--a small anticline has developed in the trough of the syncline. 


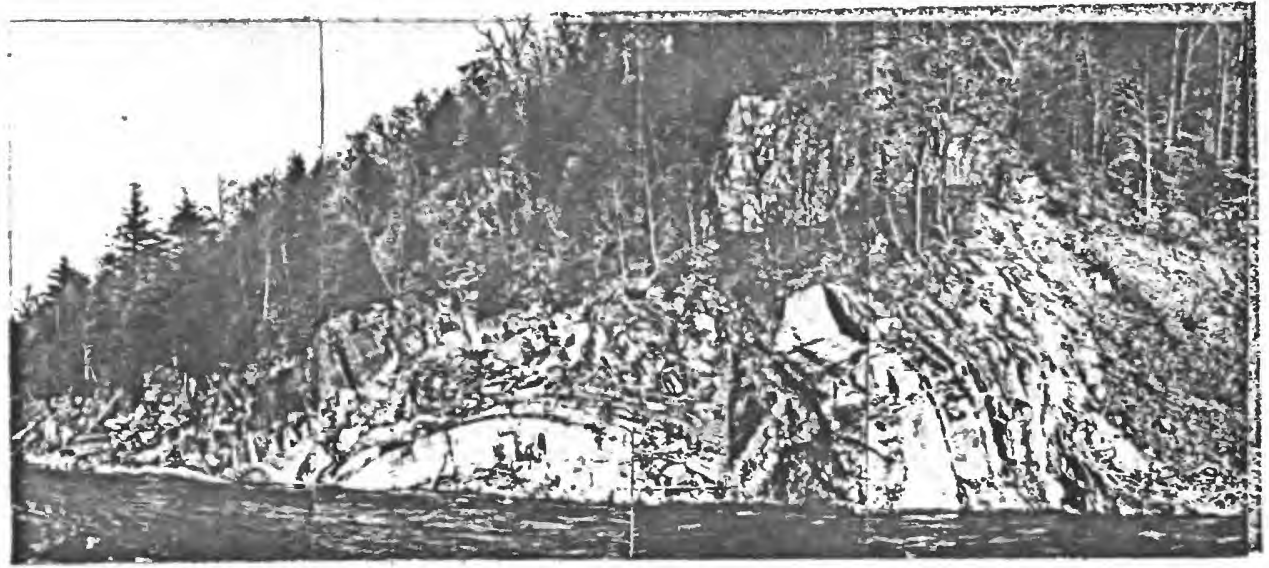

Figure 78. Folds interpreted to be cascades in the Ridgeley Sandstone (massive bed and underlying rocks) and orerlying Esopus Fonnation (with convergent cleavage fan in syncline) along Brodhead Creek, I mile east of Stroudsburg, Pa. 


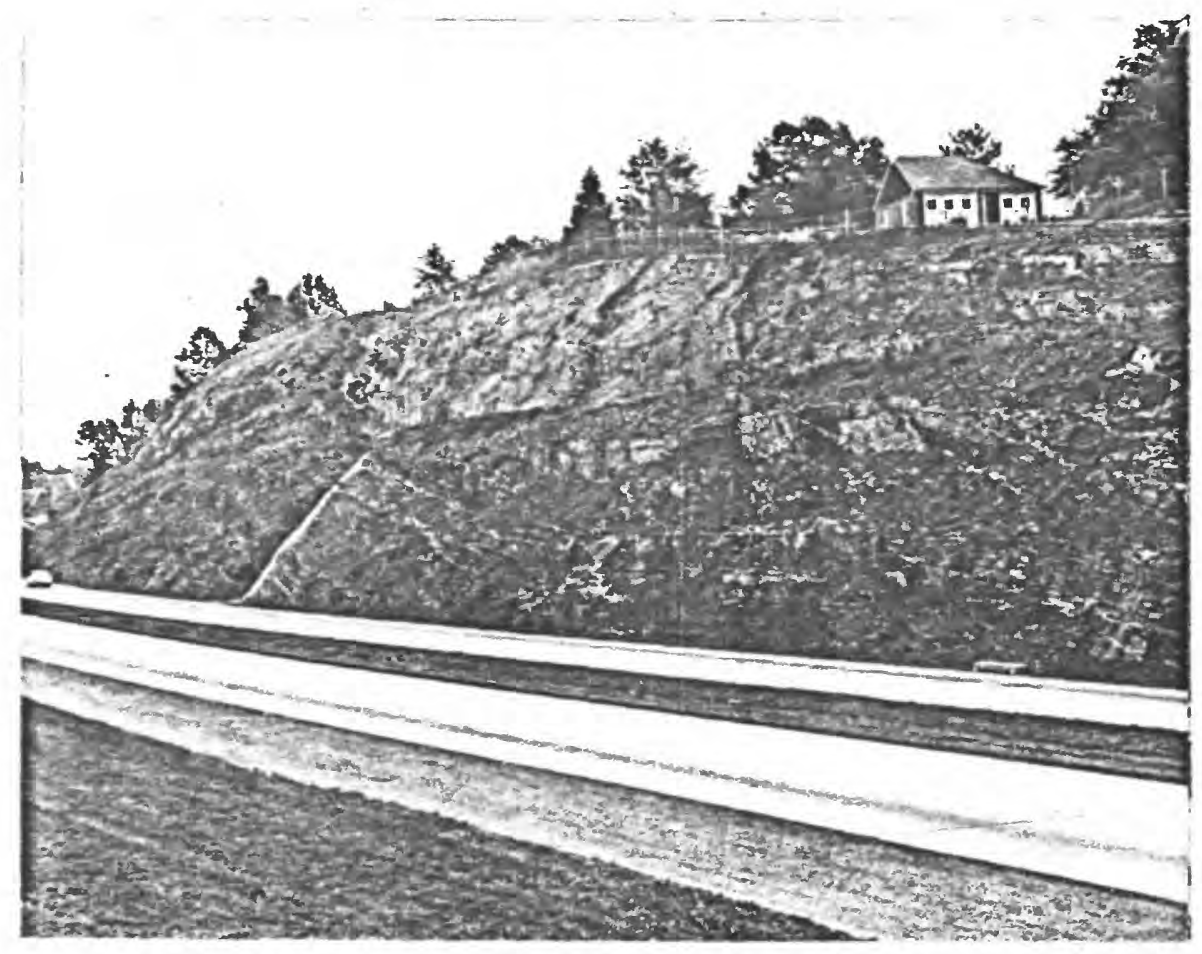

Figure 79. View parallel to the axis of an anticline (northwest limb dips northwest, to the left) in the Stroudsburg Member of the Buttermilk Falls Limestone in roadcut along U.S. Interstate 80 , Stroudsburg, $\mathrm{Pa}$. The variation in plunge is apparent. The fold is noncylindrical, and becsuse its axial plane appears to vary in dip, it is also nonplanar. Outcrop patterns are of folds in lithotectonic unit 3 thus complex (pl. III). 


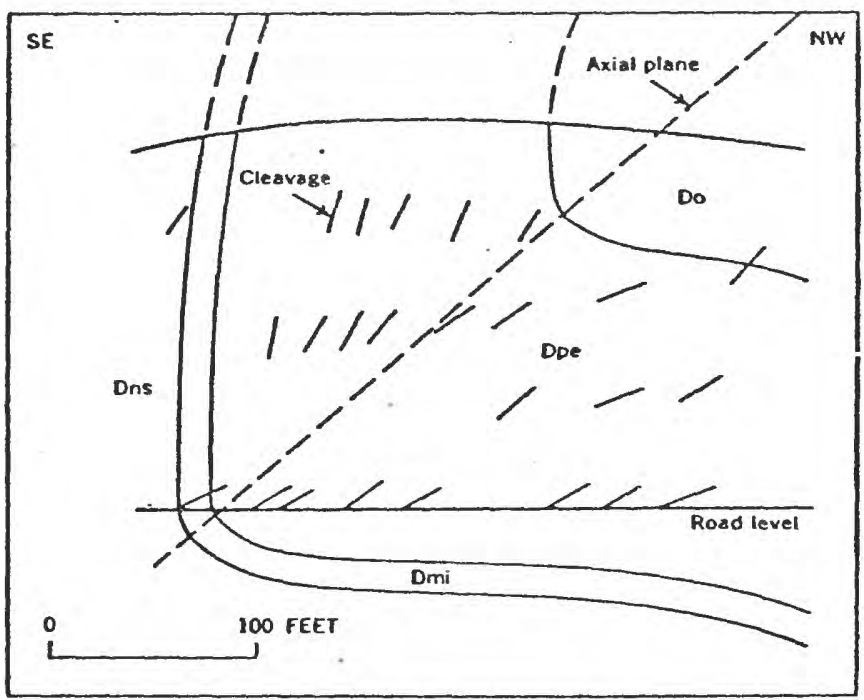

Figure 80. Geologic section showing divergent fanning of cleavage in the Port Eken Shale in Godfrey Ridge along U.S. Interstate 80 , approximately 0.4 mile southest of Minisink Hills, Pa. Figure 35 is a photograph of the exposure. Section is perpendicular to strike of beds. Vertical scale same as horizontal. Do, Oriskany Group; Dpe, Port Ewen Shale; Dns, New Scotland Formation; Dmi, Minisink Limestone. 
Few faults were seen in lithotectonic unit 3. A few 1-footthick shear zones, filled with calcite, quartz, and fragments from surrounding rock, were seen in the Port Ewen Shale in the northeast section of Godfrey Ridge. Displacment was insignificant, and they are not shown on the geologic maps. The fault cutting the Oriskany shown on the geologic map of Pennsylvania (Gray and others, 1960) nearly 2 miles east-northeast of Stroudsburg is best interpreted as a fold. One fault was mapped along Brodhead Creek in the northeast section of the quadrangle. It is a high-angle fault with the northwest block down and rotated to the southeast relative to the southwest block (fig. 81 ).

Folding and development of deformation lamellae followed by rotation in lithotectonic unit 3 has been demonstrated by Hansen and Borg (1962) as it was in lithotectonic unit 2 discussed above.

\section{Iithotectonic Unit 4}

The change from complicated folds of lithotectonic unit 3 to gently undulating beds of Iithotectonic unit 4 takes place fairly abruptly, apparently in the covered zone at the base of the Brodhead Creek Nember of the Marcellus Shale. One fold was mapped in the Stroudsburg quadrangle--the East Stroudsburg syncline. It is a broad open fold with a half-wavelength of about 4,000 feet. A moderate to gently dipping southeast cleavage is found in all exposures, but the cleavage is not as well developed as in older 11 tes. 


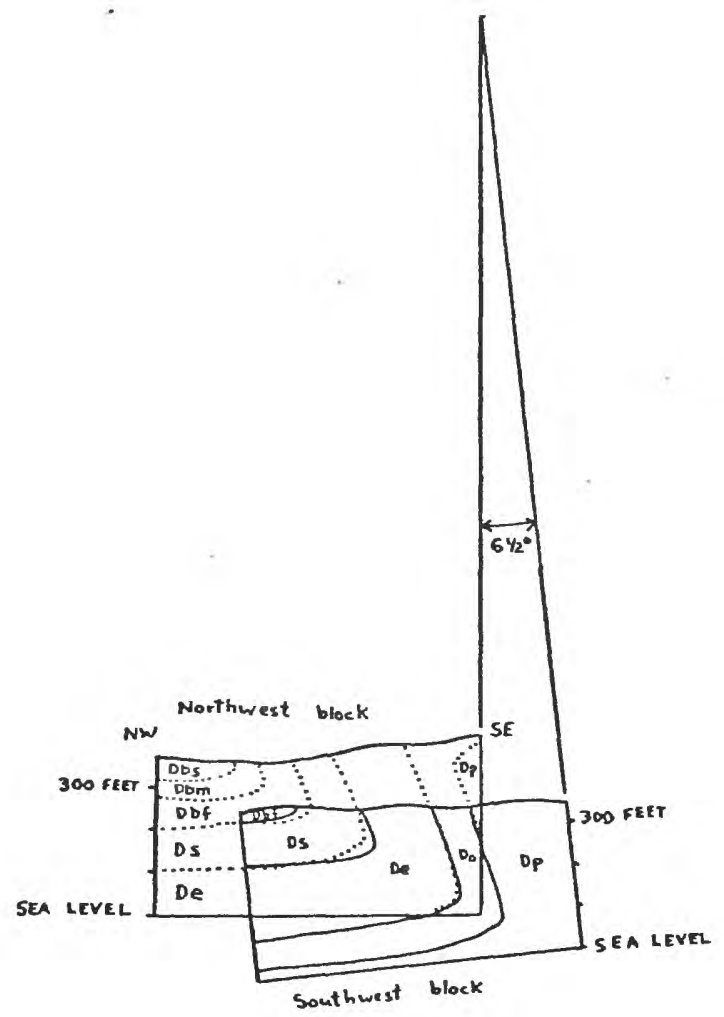

Figure 81. Cross sections of blocks on either side of highangle fault 5,000 feet southwest of Minisink Hills in Brodhead Creek. Sections are rotated so that structures and stratigraphic units are superimposed as they were before faulting. To have reached their present position, the northwest block must have moved down and rotated to the southeast with the pivot point above 1,700 feet above. Dp, Port Ewen Shale; Do, Oriskany Group; De, Esopus Formation; Ds, Schoharle Formation; Dbí, Foxtown Member of Buttermilk Falls Limestone; Dbm, McMichael Member of Buttermilk Falls Limestone; Dbs, Stroudsburg Member of Buttemilk Falls Limestono. 


\section{Small-acale Structures}

Lineations and planer elements are numerous in the Stroudsburg quadrangle and vicinity. Lineations include slickensides, elongated fossils and minerals, axes of folds, intersections of bedding and cleavage, and intersections of cleavage and cleavage. Planar elements include joints, bedding, slaty cleavage, and slip cleavage.

\section{Lineations}

Bedding-plane slickensides and slickensides on cleavage are shown on the geologic maps (pls. I, III). In general, their trends are similar in all lithotectonic units. Unfortunately, not enough were recorded so that a structural plot could be made. of interest is the increase in the number of bedding-plane slickensides in the Martinsburg Formation within a few hundred feet of the Shawangunk Formation. The significance of this will be discussed shortly.

Mineral streaks and elongated fossils are common. These comprise the "transport lineation" of some workers. These were not recorded, but they generally trend perpendicular to fold axes and parallel to direction of tectonic transport. Distinct lineations of this type are generally not well developed in slates in the Martinsburg Formation. The growth of minerals in pressure shadow areas parallel to cleavage will be discussed under cleavage.

Aside from the possibility that the variably-plunging folds n lithotectonic unit 3 are cross folds, at only one locality 
(in the Martinsburg Formation) were small-scale cross folds seen. These are located in Slateford Creek 500 feet west of the east border of the Stroudsburg quadrangle. Their axes parallel beddingplane slickensides that trend $\mathrm{N} .38^{\circ} \mathrm{W}$. The folds have wavelengths of about 6 inches (fig. 82), and they apparently developed by convergence in the b-tectonic direction as the rock was transported parallel to $\underline{\mathbf{a}}$.

Intersections of cleavage and cleavage are rare in the Stroudsburg area because a second cleavage was seen in outcrop in only a few places--in the Snowdon slate quarry in the Martinsburg Fornation (no. 25) and in the Rondout Formation on Godfrey Ridge. These will be discussed in the section on cleavage.

The only lineations that were consistently recorded are intersections of bedding and cleavage. These approximate the trend of the axes of the folds in which they occur, but it can be shown geometrically that some variation from this trend is to be expected if there is any fanning of the cleavage; that is, if the cleavage is not parallel to the axial surface of the fold in all parts of the fold. Cleavage in all rocks in the area fan the folds to some extent, but nevertheless, it does give an approximation of axial trends. Figure 83 is an equal-area plot of the recorded intersections of bedding and cleavage in the four lithotectonic units in the Stroudsburg quadrangle. A symoptic plot (fig. 106) shows that the trends are very similar in all lithoctonic units in the quadrangle. There is, however, a slightly 


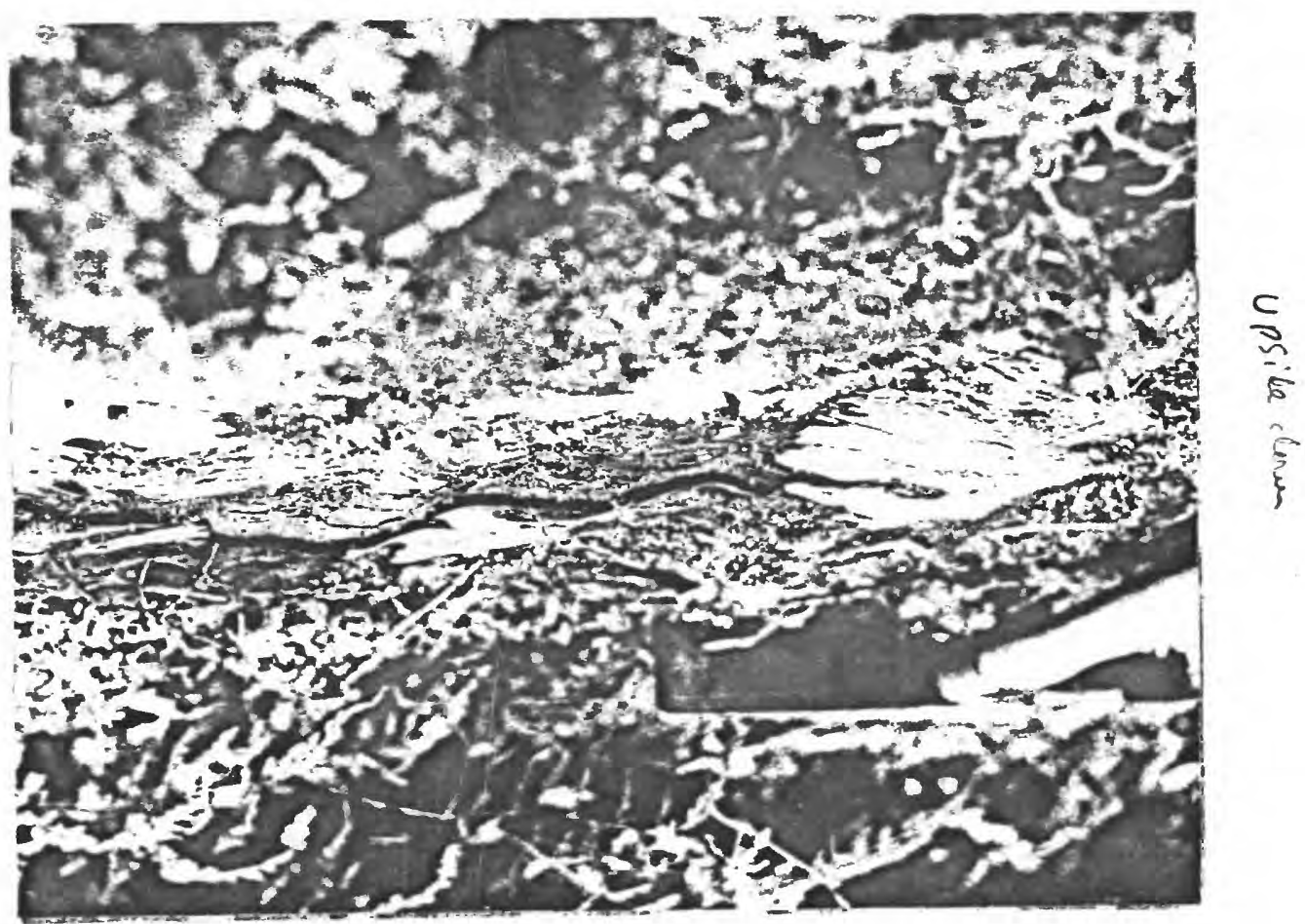

Figure 82. Small cross folds in the Martinsburg Formation in Slateford Creek, 500 feet west of the east border of the Stroudsburg quadrangle. Fold axes parallel slickensides that trend to the northwest, parallel to bammer handle. 

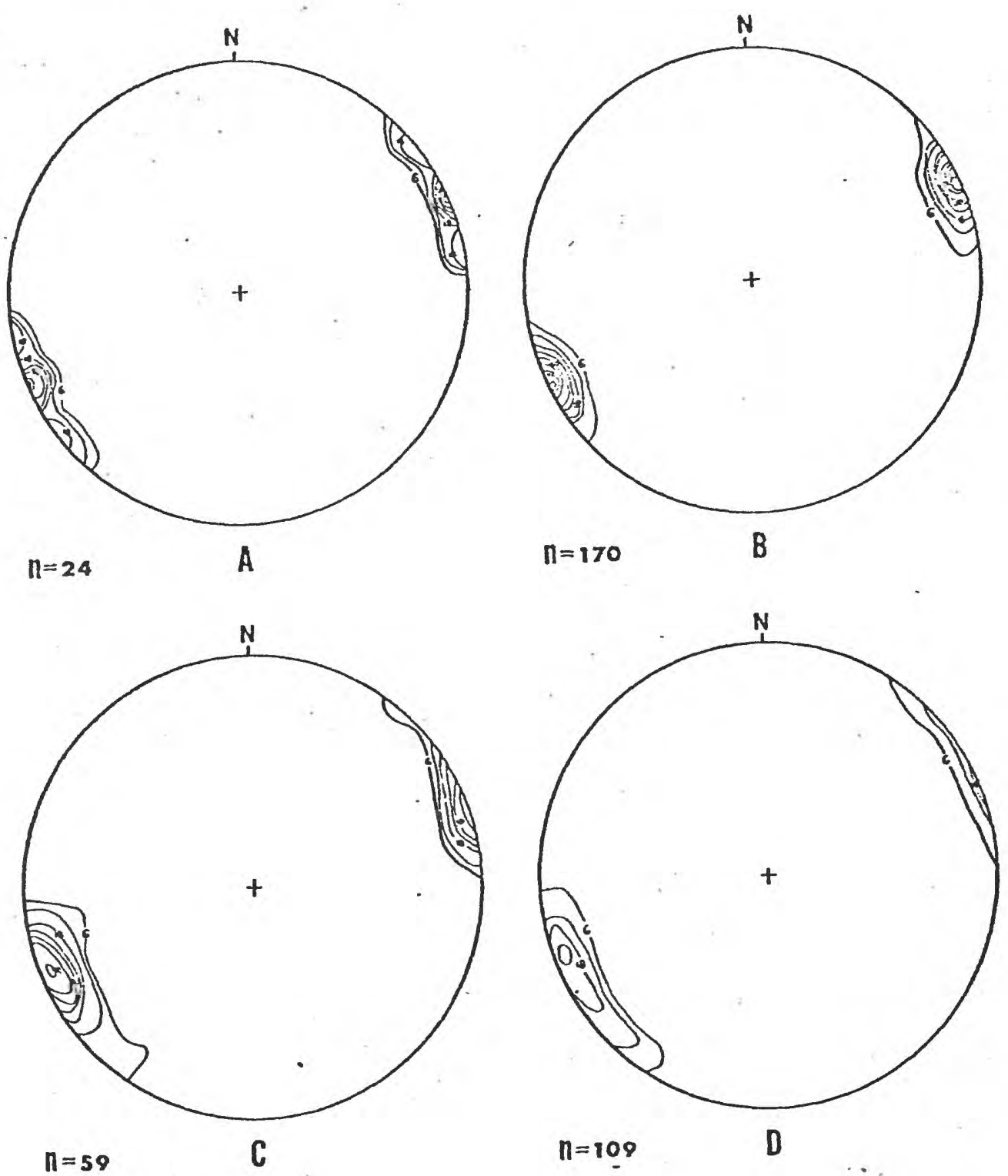

Figure 83. Equal-area projections (lower henisphere) of intersections of bedding $\left(S_{0}\right)$ and cleavage $\left(S_{1}\right)$, a lineations, in the four lithotectonic units in the Stroudsburg quadrangle. Contour interval 6 percent per 1 percent area.

A, I1thotectonic unit 4 , maximum at $2^{\circ}$, S. $68^{\circ} \mathrm{W}$.

$B$, lithotectonic unit 3 , maximum at $1^{\circ}, \mathrm{s}: 66^{\circ} \mathrm{W}$.

C, lithotectonic unit 2, maximum at $5^{\circ}$, s. $70^{\circ} \mathrm{W}$.

D, lithotectonic unit 1 , maximum at $4^{\circ}$, S. $70^{\circ} \mathrm{W}$. 
greater spread in the Hartinsburg Formation (fig. 83D).

\section{Joints}

These planar features can be conveniently related to folds as cross, longitudinal, and oblique joints. They are generally smooth to rough, planar to slightly curved fractures usually tens of feet or more in length. Calcite or quartz may line some joints. Displacement along joints, if present is never more than a few inches. Equal-area plots of joints (fig. 84) show that cross (ac) joints are very well developed in relatively competent rocks (i.e., I1thotectonic units 2 and 3) and that longitudinal joints are less vell dereloped. The joint pattern in lithotectonic units $I$ and 4 (predominantly in shales and siltstones) is more complex, and no attempt is made to decipher its structural significance. Tro useful conclustons may be made of the joint plots, however. The first is that ac foints are not orlented perpendicular to strike of bedding (see fig. 85). They are as much as $20^{\circ}$ off from the perpendicular. This further evidence that there has been rotation of joints (as well as beds) following their initial development, presumably during the latest stages of folding or just after. They are a later feature than cleavage because no cleavage was seen transecting them. The second conclusion is that joint sets served as IInes of weakness during erosion and that the numerous wind and water gaps in the area are located along these lines of weakness. This will be discussed further under geomorphology. 

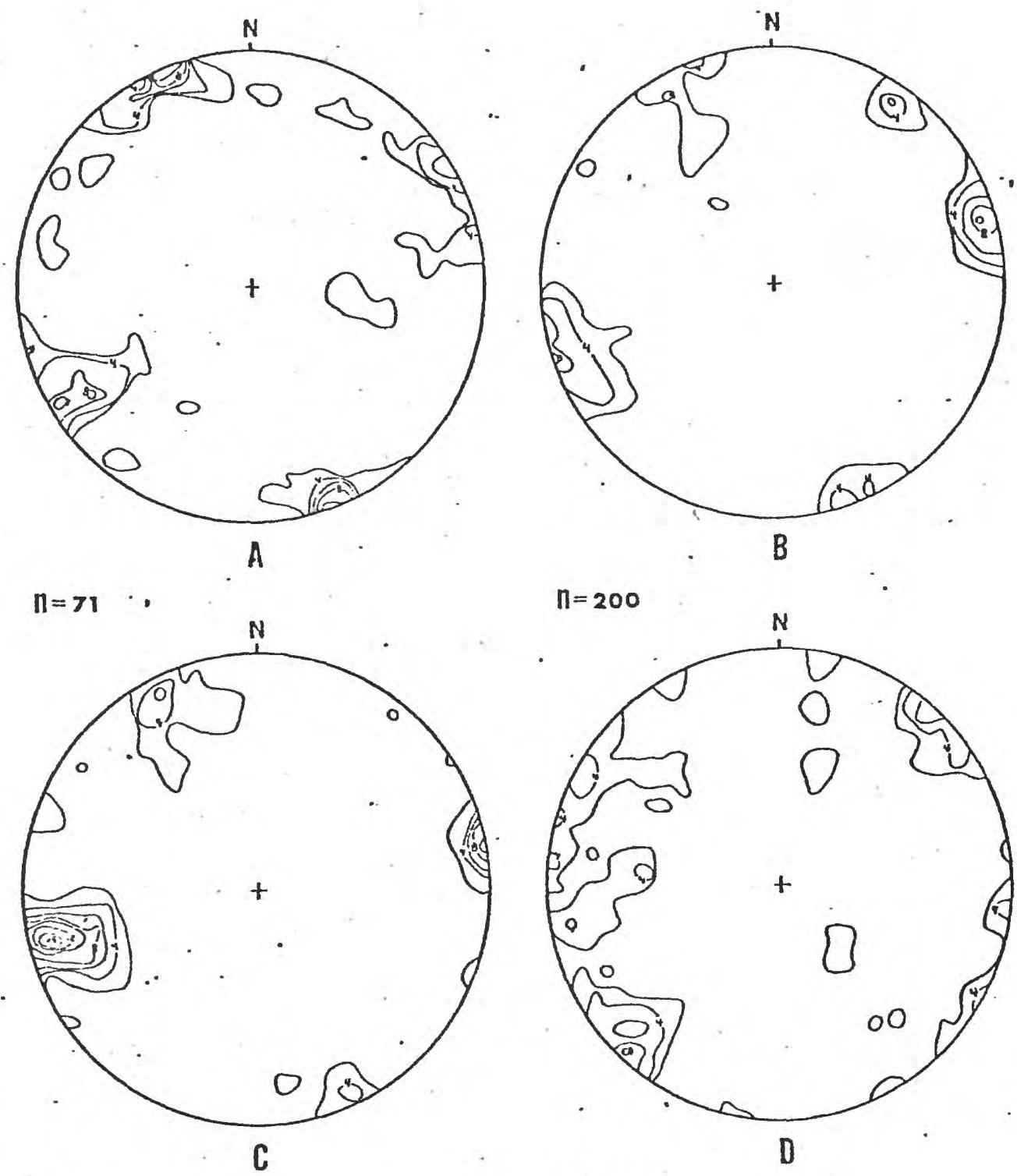

$n=177$

$n=200$

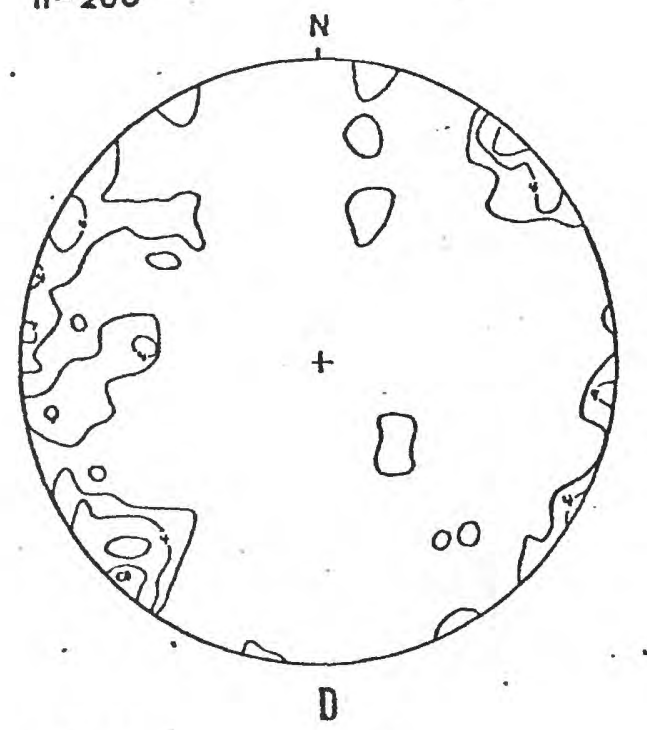

$n=120$

Figure 84. Equal-area projections (lower hemisphere) of poles to joints in the four lithotectonic units in the Stroudsburg quadrangle. Contour interval 2 percent per 1 percent area.

A, Iithotectonic unit 4

$B$, lithotectonic unit 3

C, lithotectonic unit 2

D, lithotectonic unit 1 


\section{Bedding}

Bedding is a primary planar structural feature that is used to define the geometry of folds. The characterfstics of folds have been described under the lithotectonfc units and their geometries may be further expanded by plotting bedaing on equalarea nets (fig. 85). In general, the plots of bedaing substantiate the low angle of plunge of folds in the area that is shown by plots of intersection of bedding and cleavage. Slight arcustion of the girdies, especially in Iithotectonic unit 2 ( $\mathrm{fig} .85 \mathrm{C}$ ) shows the gentle southwest plunge.

The plot of beds in I1thotectonic unit 4 shows the upright nature of the folds in that unit. The asywetric overturning In units 2 and 3 are well shown in the nets. The lack of overturned beds in the net for the Martinsburg Forration (Iithotectonic unit 1) is due to the low concentration of such beds In the area, and is not to be construed that overturning is not present in that unit. Note that bedaing waxima in the Martinsburg Is more northerly than in the other Iithotectonic units, substantiating the unconforwable relationship between it and overlying rocks. There is also the suggestion that bedaing in the Martinsburg was rotated to a more northeasterly direction parallel to beds in overlying rocks. Figure 106 shows a synopt1c summary of bedding in the four lithotectonfc units. 

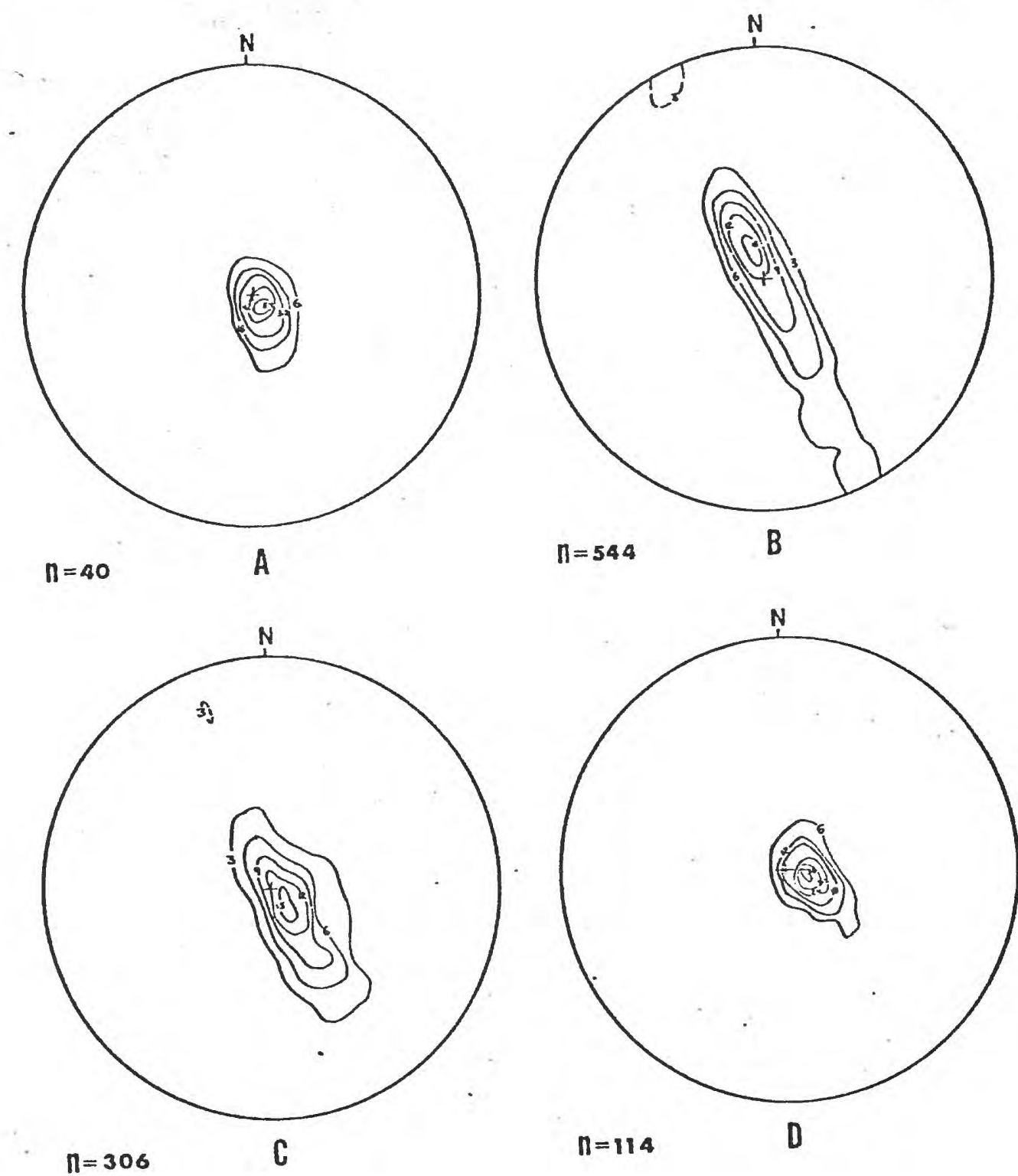

F1gure 85. Equal-area projections (lower hemisphere) of poles to bedaing $\left(S_{0}\right)$ in the four lithotectonic units in the Stroudsburs quadrangle. Contour interval for $A$ and $D 186$ percent per 1 percent area, and for $B$ and $C$ is 3 percent per 1 percent area. Dashed contours are overturned beds.

A, I1thotectonic unit 4 , maximum at N. $46^{\circ}$ E., $6^{\circ} \mathrm{NW}$. $\mathrm{B}$, I1thotectonic unit 3 , maximun at $\mathrm{N} .65^{\circ} \mathrm{E} ., 10^{\circ} \mathrm{SE}$. C, I1thotectonic unit 2 , maximum at N. $50^{\circ} \mathrm{E} ., 13^{\circ} \mathrm{NW}$. D, IIthotectonic unit 1 , maximur at $\mathrm{N} .21^{\circ} \mathrm{E} ., 8^{\circ} \mathrm{NW}$. 


\section{Cleatage}

All pelitic rocks in the Stroudsburg area have a secondary folfation or cleavege, the Intensity of which, both megascopicalIy and wicroscopically, decrease to the northwest. For years there has been disagreement concerning the conaitions under which cleavage forms. In general, two types of cleavage have been recognized; (1) flow cleavaze (often used synonymously with slaty cleavage, axlal-plane cleavage, etc.), which forwed efther by recrystalilzation of platy uinerals perpenalcular to the direction of maximum stress, or by movement parallel to planes of maximum shear; and (2) fracture cleavage, which is closely spaced Practures that are cenerally not belleved to be controlled by any mineral aligrment. A third type, slip cleavage (also called crenulation cleavage, false cleavage, etc.), Is sometiues categorized as fracture cleavage by some workers. It is usually described as closely spaced fractures alons which a previous follation (elther bedding lanination or an earlier cleavage) is dragged due to movement along the cleavage planes. Slaty and fracture cleavage are generally described in the same outcrop, the slaty varlety found in pelitic interbeds and fracture cleavace found In more competent siltstones and sandstones. The two types of cleavage are lithically controlled, they are gradational, and they apparently have a common orlgin.

The cleavage in the Stroudsburg area is a regional feature hat malntains a falrly consistent range of attitudes in all 
11. Stectonic units ( 1 ig. 86). It generally appears to be related to the folds in that it is subparailel to the axial planes of the folds and is oriented.symetrically in the folds (fans the folds). Dips are steeper in more competent units (coarse siltstone, argillaceous sandstones, and Ilmestones) than in less competent sheles and finer siltstones. In graded pelite-sandstone sequences, the change in dip of cleavage is gradual and the cleavage appears to be folded ( $\mathrm{fig} .87$ ), but this is due to gradual "refraction" of cleavage in more competent beds. In many rocks clesvage is the wost prowinent structure and results in a cleavage banding that way be mistaken for bedding.

Several "types" of cleavage are found in rocks of the Stroudsburg area. It is not the purpose of this discussion to delve deeply into the mechanics of cleavage formation. Rather, I shall describe the cleavages as they fefect interpretation of the ages of deformation in the area and present scme discussion concerning the conclusion of Maxwell (1962) that the slaty cleavage in the Martinsburg Formation is a product of diagenesis (and not metemorphism) during mild deformation of the Taconic orogeny, and that all other cleavages in the area, particularly in post-Nartinsburg rocks, are the fracture type.

No rock seen in this section, from the best slate in the Martinsbure Forwation to. Marcellus Shale with poor cleavage, has perfect allgmment of all component minerals. However, every rock fen has at least some preferred mineral alfgntwent, even where 

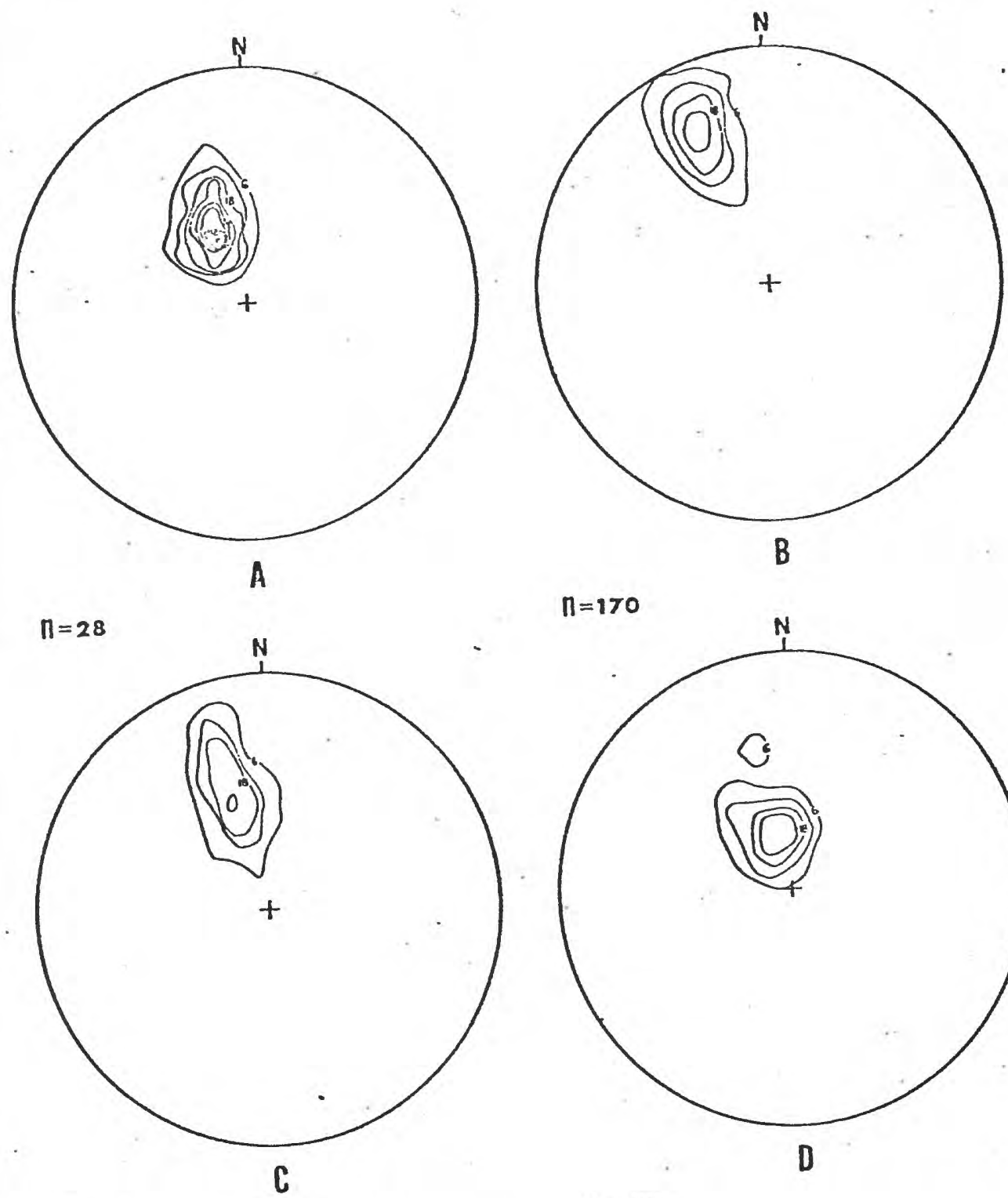

$n=59$

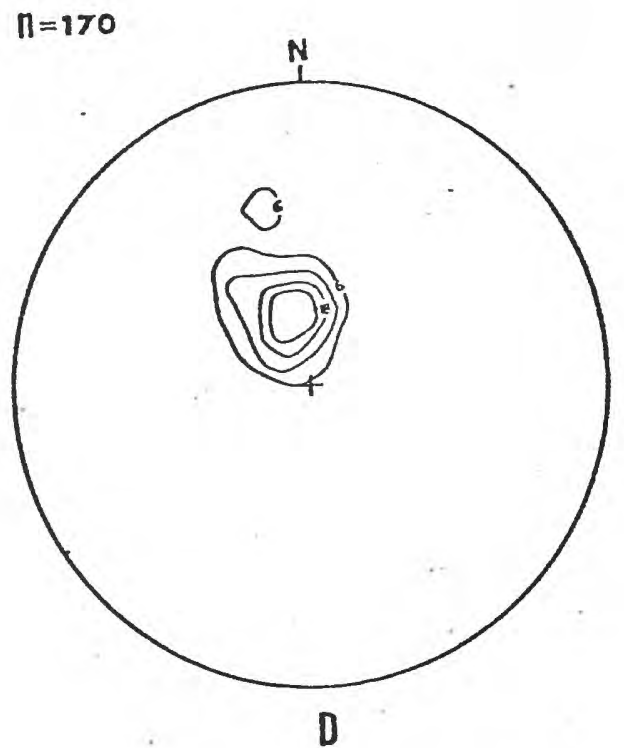

$n=116$

Figure 86. Equel-arce projections (Iower hemlsphere) of poles to cleavage $\left(S_{1}\right)$ in the four I1thotectonfc units in the Stroudsburg quadrangle. Contour interval 6 percent per 1 percent area.

A, Ifthotectonic unit 4 , maxirnum at N. $66^{\circ}$ E., $23^{\circ} \mathrm{SE}$. $B$, I1thotectonic unit 3 , maxioum at $\mathrm{N} .66^{\circ} \mathrm{E} ., 60^{\circ} \mathrm{SE}$. C, Iithotectonic unit 2 , maximum at N. $72^{\circ} \mathrm{E} ., 42^{\circ} \mathrm{SE}$. D, Iithotectonic unit I, maxdraum at N. $73^{\circ} \mathrm{E}, 1^{\circ} \mathrm{SE}$. 


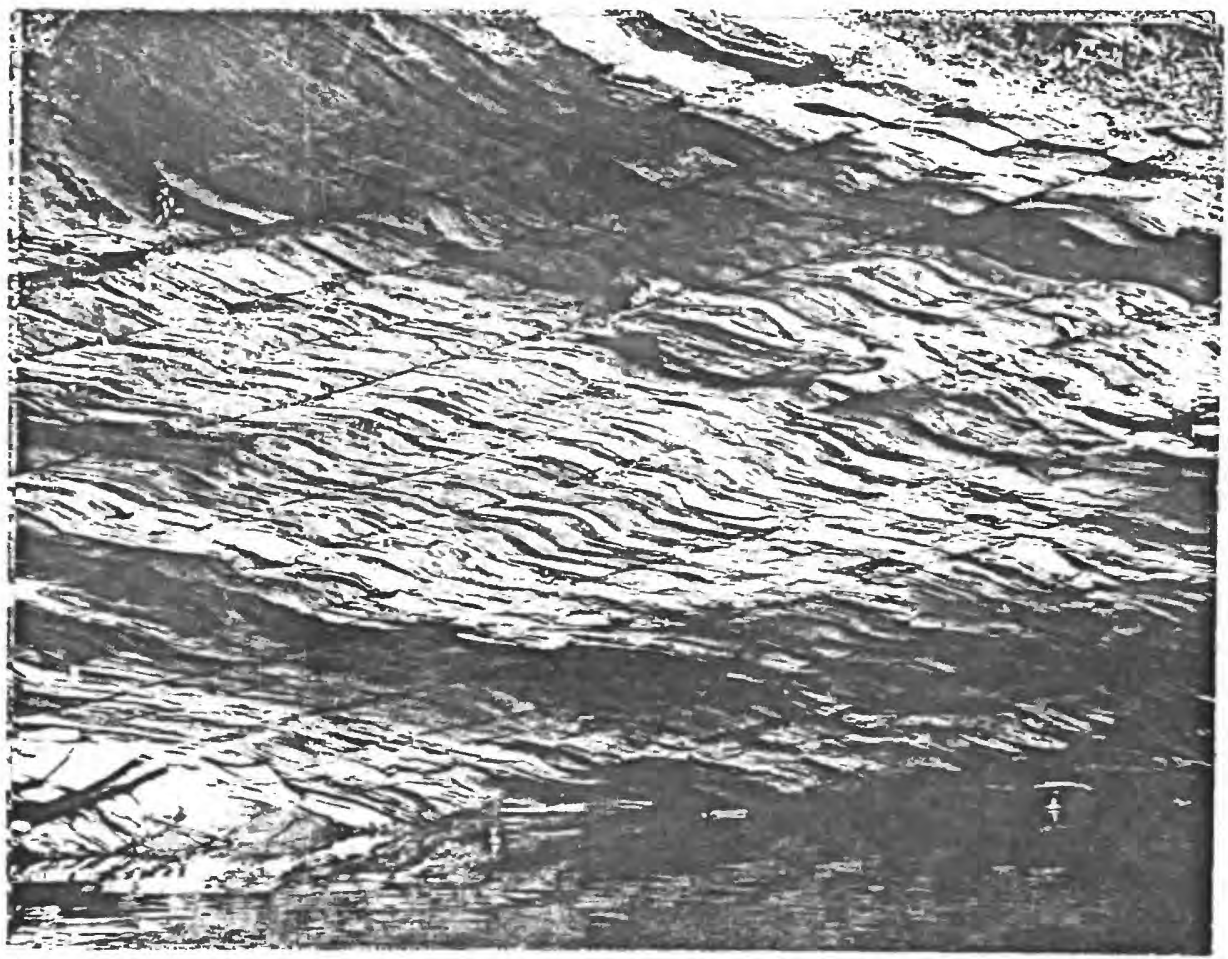

Figure 87. Refracted slaty cleavage in Pen Argyl Member of the Martinsburg Formation, Strunk quarry (no. 7), 0.5 mile southeast of North Bangor, $\mathrm{Pa}$. Bedding dips gently northwest (left) and cleavage dips gently southeast. Cleavage is steeper in siltier beds. Beer bottles floating in flooded quarry give scale. 
clearage is poorly developed. Therefore, fracture cleavage is a term that is not applicable in this area and slaty cleavage is herein used to define that cleavare whlch allows a rock to be split Into thin folle and is dependent upon the parallellsm of plety minerals and dimensional alignment of prismatic minerals for that property. Thus, the slates in the Nartinsburg Forticion have slaty cleavage and the less perfectly developed cleavage in siltstone of the Bloomsburg Red Beds, even though Bloomsburg slltstones are not slates in a comercial sense, also have slaty cleavage. I shall use "cleavgge" and "slaty cleevage" Interchangeably. There has been too much confusion steming from the complex plethora of names that exist for this follation for we to suggest others. SIIp cleavage is used as a separate type (a follation along which others are crenulated) with the full realization that it too may be mechenically equivalent to Elaty cleavage; 1.e., slip cleavage may develop in laminated or follated rocks while slaty cleavage developes in rocks of different isthology elsewhere.

Megascopically, cleavege. is characterlzed by the eesy splitting of the rock parallel to the cleavage direction (flgs. 3, 50, 98). Microscopically, In rocks of the Delaware Water Gap area, the cleavage is shown by thin folla of muscovite, chlorite, elongate quartz and calcite, and opaque minerals, presumably carbonaceous matter and Iron oxides, that are orfented parallel to one another and are separated by thin layers of quartz, mica, chlorite, and her minerals that are not oriented parallel to the cleavage 
direction (figs. 4, 6, 12, 24, 26, 40, 49, 53, 54, 88, 97, 99, $100,102,103)$. No sample seen has all mineral grains parallel to the cleavage direction. These observations are in accord with those of Schamel (1969) and Pokell (1969). The proportion of aligned minerals in cleavage folla apparently increases (I) as the intensity of deforation increases, (2) in finer grained rocks, (3) with increased percentages of platy minerals in a rock. Thus, clearage folla are farthest apart in coarser grained rocks and in more quartz-rich rocks (to which the term fracture cleavage is generally applied). Cleavage that is most closely spaced occurs in such fine-grained rocks as lithographic (micritic) limestone, such as the Bossardville Ifmestone (fig. 29), and fine-grained pelites of the Martinsburg Fortiation (figs. 4, 88). Cleavage surfaces are never perfectly swooth in outcrop. Often there are small steps that appear to be the result of the intersection of two or more cleavages. Ilkewise, microscopically, the cleavage folia are wavy and anastomose around other grains, such as quartz, in the interfolial areas (figs. 54, 88, 97, 99). The divergence in the direction of cleavage way be more than $20^{\circ}$ in small domains and gives the false appearance of two intersecting cleavages. Cleavage diverges around more rigld obstacles, such as fossils and quartz-filled burrows, by more than $35^{\circ}$, as seen in many lithologic units. Certainly, these divergent trends cannot be ascribed to more than one generation of cleavage. Perhaps the best example of this irregularity 18 illustrated by Behre 
(1933; p. 31, pl. 7A), and shows a sarple from the Mart1nsburg Formation cut perpendicular to bediding and cleavege (the bc plane).

Cleavage is at least pertly the result of recrystallization and new mineral growth (neomorphisw), but probsbly is largely the result of mechanical reorientation of minerals. Flowage is evidenced by laminar intrusions of fine pelitic, often carbonaceous, material across more rigid laminae (f1gs. 88, 94, 101). Dragging of minerals into the cleavage plane is coumon (fig. 26). Occassionally, the cleavage folia extend across shells (fig. 102), bedding-plane slickensides (fig. 88), and stylolites (f1g. 103), indicating that mobility of the waterial in the folla occurred after a certain amount of lithification occurred. The mobllity induced after lithification can certainly be ascribed to the presence of water in the rocks under conditions of, or approsching, low-grade regional wetamorphism (quartz-nuscovite-2lbitechlorite subfacies of the greenschist facies).

How much recrystallization occurs after flowage starts is difficult to say, but undoubtedly there has been some recrystallization and grain diminution in cleavage folla (figs. 88, 95, 100, 102) as well as growth of porphyroblasts (f1g. 88) and growth of new minerals in pressure-shadow areas around other grains such as pyrite (figs. $29,88,99,101$ ). Similarly, quartz, derfved from pebbles adjacent to a shale layer, and was intruded Into the shale parallel to the cleavage, is strong evidence for recrystallization (fig. 95). 
There appears to be crushing and stretching of mineral grains in cleavage folla, suggesting considerable recrystallization. In general, minerals are finer grained in the cleavage folla than in Interfolfar areas. Evidence of grain difulnution and stretching is to be found where cleevage cuts through coarse quartz-rich lawinae, quartz grains, shells, etc. Extensive recrystallization has not taken place in all cases. In many instances, it appears that quartz grains have "floated" during flowage of materfal making up the cleavage folla (fig. 101). Thus, it is concluded, that slaty cleavage is the result of flowage of material, crushing of certain mineral grains, recrystallization, and Erowth of new minerals. Both cataclasis and lowest grades of regional metamorphism are epparently involved. Initiation of cleavere, as represented in the youngest rocks (those in the highest tectonic levels), appears to have occurred below the level generally ascribed to lowest greenschist facies wetamorphism.

The intensity of cleavege development and other tectonite phenomena in the Stroudsburg area appears to be related to (I) 11thology---fine-grained pelites show greater mineral readjustwent thas coarser grained, heterogeneous, and wore competent rocks, (2) afe and depth of burleI--younger rocks were less deeply buried, (3) total strain related to distance from source of tectonism--all rocks, including those in the Martinsburg Formation, become more severely deformed to the southeast. 
Several methods may be used to compare degree of deformation in rocks in the Stroudsburg area. The first is enpirical observation in outcrop--well developed cleavaze occurs as nearly flat continuous planes over large areas of the outcrop (1igs. 69, 98) as opposed to more poorly developed Irregular cleavage surfaces ( $f 1 g .52$ ). This of course may depend to a large part on lithology, so rocks of the same type must be compared. The second is to what degree porphyroblasts have grown in the rock (figs. 4, 88). The third is amount of pressure-shadow mineral growth in the cleavage planes arcund orfglnal rigid grains such as pyrite (figs. 29, 88, 99, 101). The net minerals in the pressureshadow areas suggests that these are zones of least pressure parallel to the alrection of maximum extension. Zones of greatest pressure (perpendicular to the greatest stress axis) occur parallel to cleavage, so that quartz grains and other winerals, and most dramat1cally, fossils ( 1 1g. 29), are dissolved adjecent to cleavage laminae. Finally, there are the effects of deformation on quartz. Fellows (1943) has shown that quartz has certain textures that progressively change from one into the other with increasing intensity of deformation. Four of his types are recognized In the Stroudsburg quadrangle: 1) orlginal grains--these show Iittle apparent effect other than the development of strain shadows. These do not appear to be common--most quartz grains have corroded or Intergrowm borders; 2) peripheral growth quartz--opt1cally continuous quartz overgrowths characterize these forms. They are 
of ten accompanied by adjolning quartz grains with sutured or straight contacts (perhaps solution of silica along these contacts supplied quartz for the overgrowths; 3) crush quartz--perhaps a poor term, indicating apparent granulation or growth of smaller grains of quartz as well as shreds of mica, chiorite, and calcite around the grain in the plane of wovement (generally paraliel to cleavage where apparent in the rock); and 4) needle quartz--slivers of quartz that have been stretched parallel to a to lengths greater than three times their widhs. These "tailed" clusters may join two parent quartz grains (fig. 100) and be intergrown with neocrystallized mica. Recrystallized quartz with a granoblastic texture, the last variety discussed by Fellows, is very rare in the rocks of the stroudsburg area.

Slip cleavage is not as pervasive as slaty cleavage. It appears as a serles of subparallel planes where a previous slaty cleavage or bedding laminations have been crinkled (flgs. 73 , 89, 96). The slip cleavage is generally parallel to axial planes of the crinkles, the limbs of which are thinned and in places sheared off along the cleavage. Mca, chlorite, and other minerals are transposed by mechanical rotation into the new cleavage direction, but there may be some new mineral growth (f1gs. 89, 96). When enough minerals have been rotated subparallel to the slip-cleavage direction, fractures appear in the rock, apparently not before. This mechanism discounts the usual supposition that 
been dragsed. Rather, it is the parallel alignment of the minerals that allows the rock to be fractured. With continued rotation, the minerals may be nearly coupletely transposed so as to obliterate bedding or any carlier cleavage that may have been present. Slip cleavage is common in the Martinsburg Formation south of the Stroudsburg quadrangle and rare within the quadrangle, a fact noted by Echre $(1933$, p. 36). It is rare in younger rocks and was found only in the Shawangunk and Rondout Formations (figs.96, 105). Southestwarả, slip cleavage becomes comon in progressiveIy younger rocks, so that it transgresses the Martinsburg-Shawangunk contact in the Lehigh River area and is also common in that area in rocks younger than the Martinsburg (Epstein and Epstein, 1969). Cleavage In Litbotectonic Unit I

Slaty cleavage is perhaps the most prominent planar feature In fine-grained rocks of the Martinsburg Formation (f1gs. 3, 69) and it is because of this excellent cleavege that the Martinsburg has been extensively quarried in eastern Pennsylvania for more than 140 years. The cleavage consists of thin folla of oriented minerais separated by interfolial areas dominated by quartz in which mineral orientation is not as marked. Very pale green chlorite, Intergrown with muscovite, in grains as much as 20 times the size of the groundusas minerals, are found in many samples. The chlorite-muscovite grains are elongated parallel to cleavage and are thought to be porphyroblasts. This contention is strengthened y the fact that chlorite and muscovite with similar optical 
properties have grown parallel to cleavage in pressure-shadow areas around pyrite. This 18 also supported by couparison with similar chlorite-muscovite grains in younger rocks, such as the Bloomsburg Red Beds ( $118 \cdot 26$ ). These grains in the Bloombburg are mostly detrital and are about the same size as, or perhaps a Ilttle larger than, assoclated quartz. Moreover, the chloritemuscovite grains are elongated parallel to bedding. Similar grains in the Martinsburg, on the other hand, are elongated parallel to cleavage, and are 5-10 times larger than the largest quartz graln. Clearly, the large muscovite-chlorite grains in the Nartinsburg are metamorphic. Many quartz grains in the Martinsburg are elongated parallel to cleavage and have "crush" borders and mineral growth parallel to cleavage (fig. 4). Behre (1933, p. 177) noted that elongate quartz may have a length: w1dth ratio of as much as $5: 1$, and maintained that their elongation was due to metamorphism. The features just described are shown in f1gure 88. One plausible explanation for the relations shom in figure 88 is that the Martinsburg was competent enough to fail by flexural slip during the initial phases of folding (indicated by the bedding-plane slickensides) and later, as deformation increased in Intensity the rock falled plastically with the development of cleavarge and shortening of the Blickensided bed. Mobilization causing Intrusion of the pelitic folla along cleavage way have been aided by expulsion of interstitial water or water libered from hydrous minerals during inftiation of metamorphism. 
Figure 88. Negative print of thin section (below) and photomicrozraphs (above) showing relations in slaty cleavage in Pen Argyl llember of the Martinsburg Formation, New Peerless quarry (no. 6), 3,000 feet southeast of North Bangor, Pe. Dark (graphitic?) pelitic material (appearing white in lower photograph) intrudes slate along cleavage planes for distances of more than $2 \mathrm{~cm}$. The folla cut across bedding-plane slickensides (dark vertical calcite bed) and converge where they do so. Quartz grains as much as 0.15 mo long have groun parallel to cleavage along the slickensides, although this is not visible in the photograph. Quartz grains in the area where cleavage is most appressed have length:width ratios averaging 4:1 and are elongated in the cleavage direction. Porpbyroblasts of intergrown chlorite and muscovite (B) are much larger than the groundmass minerals and as much as 10 tiwes larger then associated detrital quartz grains. Chlorite and muscovite, and minor quartz, have grown in pressure-shedow areas around botryoldal pyrite (A). 


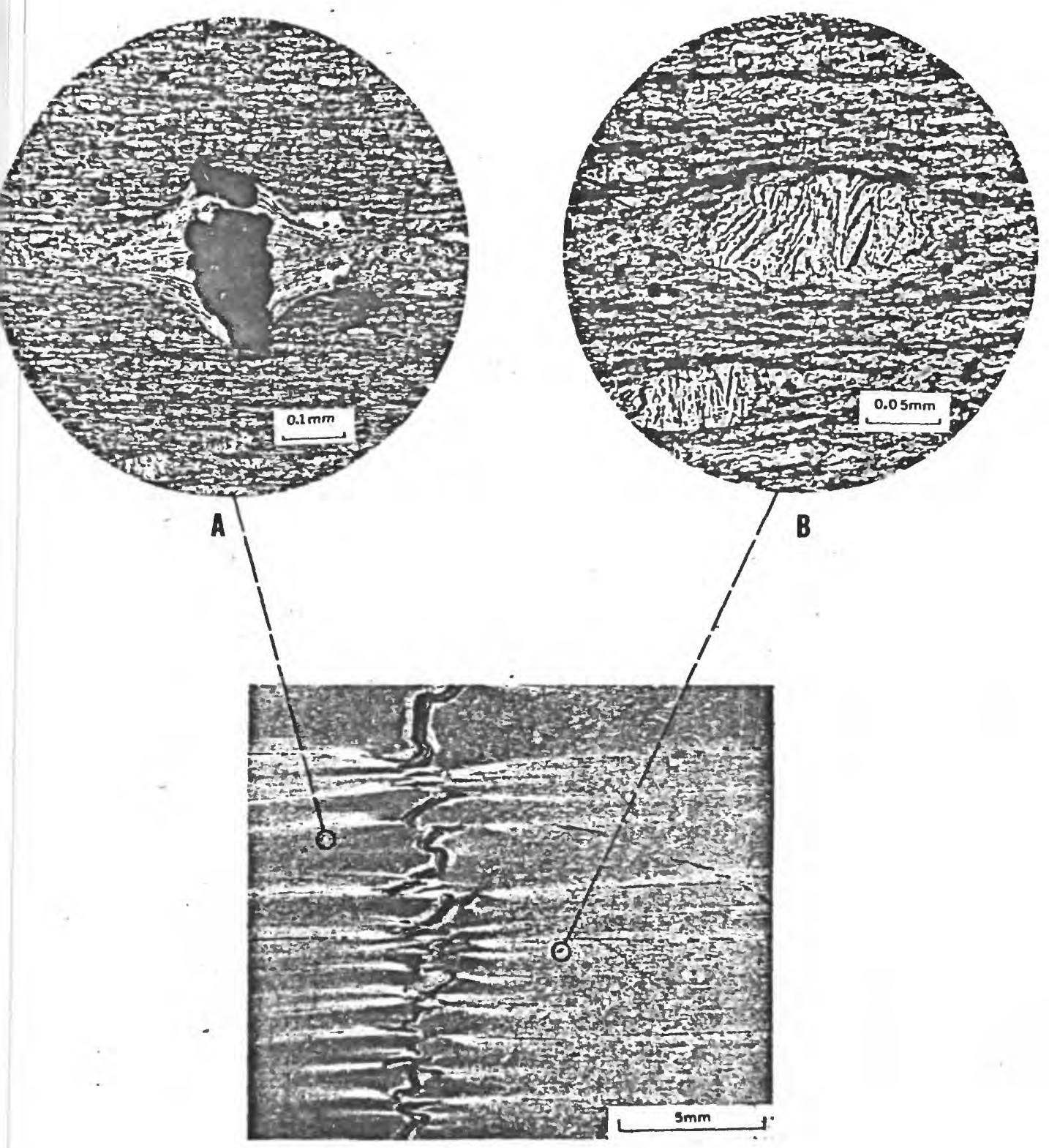


As mentioned previously, slip cleavage (11g. 73) is not cormon in the Martingburg in the area of this study. Behre (1933) reported a few occurrences in quarries that I did not see because of cover, but he noted the general paucity of slip cleavage in this area. Slip cleavage increases in intensity to the southeast, and reorientation of minerals along the new cleavage may nearly transpoge the alfgnment from the earlier cleavage. In figure 89 , about 25 percent of the minerals have been rotated into, or nearly into, the slip cleavage direction, although in other parts of the sample the figure is as high as 50 percent. This sample 1s from the Bushkill Member of the Martinsburg Formetion in the Wind Gap quadrangle, 10 miles southwest of the southwest corner of the Stroudsburg quadrangle. Ifo samples of complete transposition have been seen, but it is suspected that if the process went to completion, a second slaty cleavage, as defined here, might have formed, as suggested by Broughton (1946) for the Martingburg in New Jersey. Note in 1 fgure 89 that pressure-shadow growth of muscovite and chlorite parallels the earlier slaty cleavage and has been rotated into the slip cleavage. Also note that new mineral growth has occurred along the second cleavage cutting across the earlier formed minerals. Thus, neocrystalIization is shown to accompany both slaty cleavage and later developed slip cleavage. 


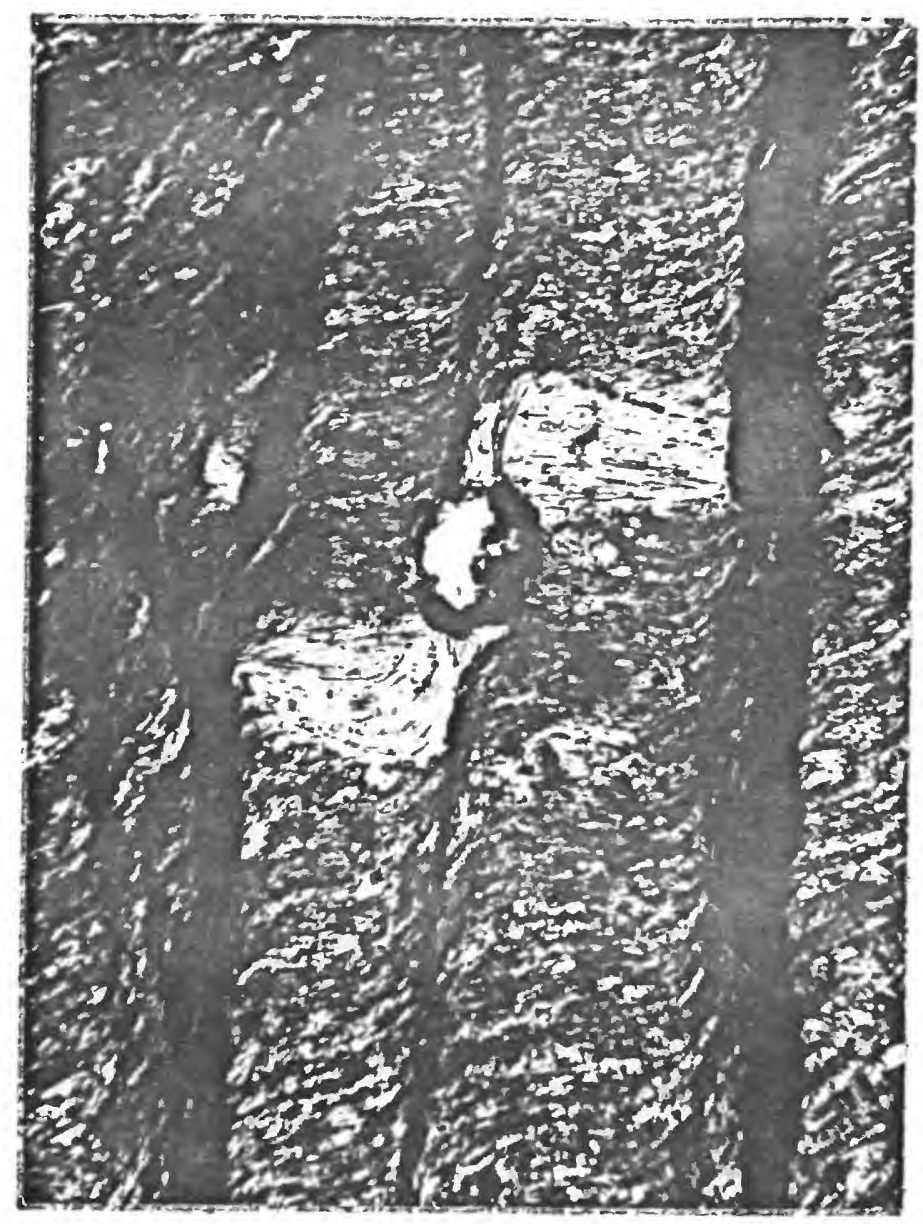

Figure 89. Photomicrogreph (plane-polarized 11ght, x 170) of slip cleavage (vertical graphitic? folla) crinkling horizontal slaty cleavage. About 12 percent of the field has been transposed Into the slip cleavage direction and another 13 percent is drasfed towards this direction. quartz and lesser chlorite, and possibly minor muscovite, in the pressure-shedow fringes around dark circular IImonite grain (probably pseudomorphous after pyrite; grain partiy missing due to grinding in preparation of thin section) is rotated into the second cleavage direction. Note also that there has been new growth in the pressure-shadow areas in the slip cleavage direction and that new growth cross cuts the older generation minerals (arrow). This shows that neocrystallization occurred during development of both slaty cleavage and later slip cleavage. Sample from Bushk11l Member of the Martinsburg Formation, south edge of the Wind Gap quadrangle, 10 miles southwest of the southwest corner of the Stroudsburg quadrangle, and 4 miles west of Stockertow, $\mathrm{Pa}$. 
Slaty cleavare penetrates all pelitic rocks of the Nariinsburg Formation and is vell developed except within a few hundred feet of the contact with the overlying Shawnngunk Formation where the cleavare either disappears (as at Delaware Water Gap, Beerbower, 1956, and Lehigh Gap, Epstein and Epstein, 1969, p. 182, and at the Yards Creek hyoroelectric puroped storage facllity, 4.5 miles northeast of Delaware Water Gap) or becomes very poorly developed and resenbles cleavage in younger rocks such as the Marcellus Shale (i.e., the Martinsburg near the Big and Little Offsets and south of Totts Gap in the Stroudsburg quadrangle). This phenomenon takes place just beneath the Sharangunk and occurs in many stratigraphic horizons within the Martinsburg. Thus, the poorly developed cleavage in the Martinsburg is related to proximity to the Shawangurk Formation and not any particular stratigraphic level within the Martinsburg.

In eddition to the poorer development or disappearance of the cleavage, the moderately southeast-dipping cleavage in the Martinsburg Formation in the Delaware Water Gap area flattens within 2,000 feet of the Shawangunk contact and then dips gently to the northwest as the contact is approached ( $f 1 g .90)$. This is accompanied by development of numerous bedding-plane slickensides indicating northwest translation of overriding beds. These relations may be explained in four ways: -1) external rotstion or arching during Appalachian folding of cleavage formed during Taconic orogeny (Drake and others, 196́, p. B181; Maxwell, 1962, p. 285). This 


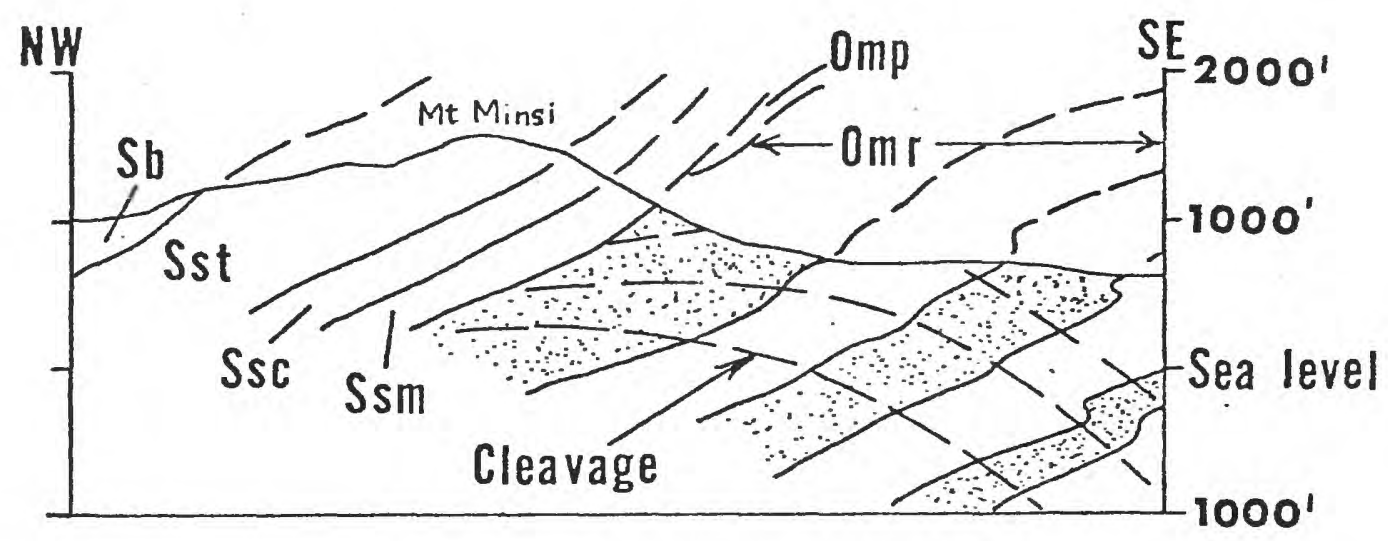

Figure 90. Geologic section through lit. Mins1 in the Delaware Water Gap area showing the "arching" of the cleavage in the Nartinsburg Formation adjacent to the contact with the Shawengunk Forwation. The cleavage is generally steeper than shown in graykacke beds. Trend of section is the same as for section $F-F^{\prime}-F^{\prime \prime}$, plate II. Sb, Bloomsburg Red Beds; Sst, Tammany Member of the Shawangunis Formation; SEc, Clinton Member of the Shawangunk Formation; Ssm, Minsi Member of the Shawangunk Formation; Omp, Pen Argyl Member of the Niartinsburg Formation; Omr, Raraseyburg Nember of the Nartinsburg Formation. Stipple Indicates graywacke-bearing intervals in Onr. Horlzontal scale = vertical scale. 
pothesis is rejected because (a) the cleavage "arch" is anticlinal--no similar structure is seen in bedding which should have been similarly rotated. Rather, the "arching" of cleavage occurs in a northwest-dipping sequence of beds; (b) a similar anticlinal arch cannot be reasonably extrapolated in the Shawangunk that would have overlain the arch; (c) cleavage in the Martinsburg is not rotated by an amount equivalent to the dip of beds in the nearby Shawangunk. For exanple, if the cleavage in the Martinsburg In the outcrop Just south of Tctts Gap were rotated back to the southeast by about $35^{\circ}$, the dip of beds in the Shawangunk above, then the cleavage would have originally been verticsl. Similar rotation in areas to the southwest, where the Shawangunk is overturned, would wean that the cleavage in the Martinsburg orfiginally dipped to the northwest, an obvious contradiction to assumptions that have been made conceraing the regional orfentation of cleavage in the Martinsburg and related rocks in eastern Pennsylvanta.

2) Drageing of cleavage near the contact by the northwestward overriding Shawangunk (1nternal rotation in the domain envisioned). This implies that the cleavage is partly, at lesst, pre-Blue Mountain décollement and may therefore be faconic in age. I suggested this possibility earlier (Epstein and Epstein, 1967, p. 31) but now discount it because the dragged cleavage should have a sigroldal shape between bedding-plane slickensides, as they In the Bloomsbure Red Bed.s where this has occurred. Such is 
231

ot the case--the cleavage is not deflected at bedaing slip surfaces.

3) The cleavage was produced by force couples due to interbed shear. This implies that the cleavage formed during norithest movement of beds in the Martinsburg. Because this northwest movement take place near the Showangunk contact (a simflar situation at Leh1gh Gap), it is presumed that it occurred after depsition of the Shawengunk (1.e., during the Appalachian orogeny). The reason for this is that the movement and "arching" of cleavage occurs in different stratigraphic levels within the Martinsburg (Rauseyburg. Member in the Delaware Water Gap area and Pen Argyl Mamber in the Lehigh Gap area) and the only apparent controlling fector is the proximity to the Shawangunk. Therefore, it seems reasonable to suppose that the Shawangunk had some influencs on the structures in the Imediately underlying Martinsburg---the "arching" of cleavage, the dying out of cleavage, and the apparent decrease in metamorphic grade as the contact is approached that will be discussed shortly. There appears to be little argument agains this third suggestion, except that elsewhere to the southwest in the Stroudsburg quadrangle the cleavage does not dip to the northwest. The cleavage, however, does die out or is poorly developed near the Shawangunk contact. Unfortunately, exposures are very poor and relations are poorly known.

4) The orientation and dying out of cleavage 1s perhaps best explained by a pressure-shadow mechanism. On a smaller scale as 
seen in thin section, cleavage is seen to curve around clastic grains, smaIl lenses of sandstone ( $f 1 g .94)$, sand-fllled burrows, fossils ( $\mathrm{f} 1 \mathrm{~g} .101$ ), etc. Cleavage is most intensely developed (Plattening is greatest) on top and bottom of these more comptent bodies and is absent or poorly developed in areas of maximum extension parallel to cleavage where neocrystallization may taise place in the areas of lower pressure (fig. 88). In many small folds of interbedded cleaved pelites and poorly cleaved more competent rocks, cleavage diverges around syaclinal troughs and Is either poorly developed or absent in the pressure-shadow area next to the trough ( $f i g .91$ ). If the relationship is true on a larger scale (compare with fig. 90) It may explain the arching of cleavage and dylag out or poorer development of cleavage as the contact with the Shawangunk Formation is approached. This mechan1sm Implies that the cleavage is post-Shawangunk in age.

Similar strongly divergent fanning of cleavage in incompetent beds with axial-plane follation near concentrically folded more competent layers has been 1 llustrated by numerous investigators (Dieterich, 1969, p. 157, for example).

\section{Metamorphism in the Martinsburg Formation}

Most previous studies of the slates of eastern Pennsylvania have attributed the origin of slaty cleavage to processes operatIng under metamorphic conditions. Maxwell (1962), on the other hand, sugsested that cleavage in the Martinsburg Formation in the Delaware-Water Gap area was produced during the Taconic orogeny 


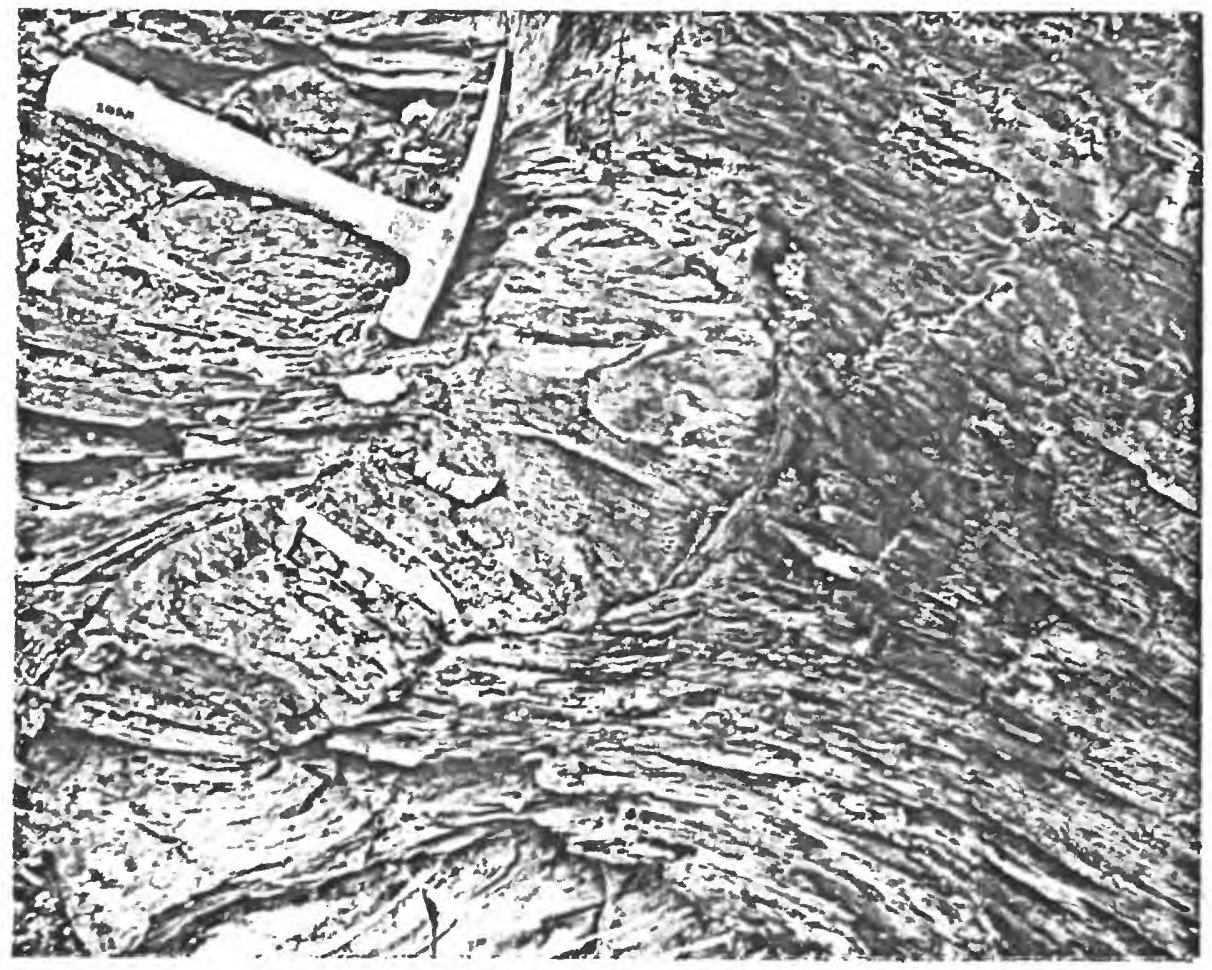

Flgure 91. Divergent fanning of cleavage in flattened fold in lower part of the Bushkill Metnber of the Hartinsburg Formation, along U.S. Route $46,1.8$ miles northeast of Eelvidere, N.J. Slaty cleavage in pclite diverges around syncline to lower right of hammer in the more competent micaceous fine-grained dolomite and 18 less well developed at the trough. The relations in the area Just under the trough compare well with those shown at Delaware Water Gap ( $11 g .89$ ). 
and was the result of only slight stress on pelitic sediments with high pore-water pressures. The slate produced, therefore, is not a metamorphic rock, but is rather a proauct of diagenesis. As a consequence, Maxwell concluded that the effect of the Taconic orogeny in this area was minor. Fracture cleavage was produced in the Nartinsburg after it was dewatered and in younger rocks during the later, more Intense, Appalachian orogeny. Maxwell's Ldeas have stimulated similar conclusions elsewhere (Koench, 1966, 1970; Carson, 1968; Clark, 1969; Powell, 1969; Braddock, 1970) and, because his hypothesis was formulated to explain cleavage in the Delaware Water Gap area, it will be alscussed at length. The origin of cleavage as I have presented it above, disagrees with Maxiell's concept in certain important detalls--mainly, the age of the cleavage in the Martinsburg, the temperature-pressure conditions under which the cleavage formed, and type of cleavage Identified in post-Martinsburg rocks, and the general field relations.

Most pertinent to the alscussion of the age and origin of the slaty cleavage is the type of mica in the slate. Most workers have identified it as "sericite" and a product of metamorphism. Maxwell (1962), on the other hand, based on the work of Cuthbert (1946) and Bates (1947), suggests that the mica is dominantly "Illite" and was not effected by elevated temperature and pressure. This is interesting because Bates (1947, p. 635) believed that the mica was a product of metamorphism. Cuthbert 
46) identiffed the "clays" in the Mirtinsburg as "illite" using differential thermal analysis techniques; Whitten (1966) cautioned agalnst the reliance on such 1dentifications during 1946-47. Yoder and Eugster (1955) showed that many terms applied to micas, such as illite and sericite, are not meaningfur, and that several polymorphs can be recognizea which are sequentially transformed during progressive metamorphism of a sediment. For purposes of this discussion, IM muscovite will be considered equivalent to "1llite" that is stable under conditions of diagenesis, and am wuscovite is the stable forw at elevated temperatures associated with metamorph1sm (Yoder and Eugster, 1955, p. 246).

Several samples of Martinsburg slate were routinely X-rayed during mapping in the Delaware-Lehigh River area. Because of complex minerelogy, the traces were not well enough defined to accurately designate the polylworph of muscovite present in the rock, although an muscovite was indicated. The muscovite was concentrated in sexmles by boiling in $6 \mathrm{M} \mathrm{hydrochloric} \mathrm{acid} \mathrm{for}$ 3 hours to remove chlorite and calcite. Muscovite and quartz were then the major minerals remaining and $\mathrm{X}$-ray diffraction traces clearly show that the dominant polymorph is $2 \mathrm{M}$ muscovite. Albite is also a component of most Martinsburg pelftes. Its presence created problems in polymorph identification, which need not be discussed here, but it too is considered to be partly a product of metamorphism, as discussed below. 
Maswell (1962, p. 298) stated that if the dominant micaceous mineral is "seric1te", or $2 M$ muscovite (which he disagrees with), then "the mica for the most pert is a projuct of metamorphism of clay ralnerals, presumably at high pressure and elevated temperature." The occurrence of $2 k$ muscovite, however, does not prove metamorphIsm (although it strongly supports 1 ), because the source area for the Martinsburg may have supplied 24 muscovite. However, the contention that the dominant mica is "illite" (presumably IM muscovitel is shown to be suspect.

All samples of slate from the Martinsburg that were $\mathrm{X}$-rayed contain recognizable albite, except those samples near the Shawangun's contact where slaty cleavage is poorly develoged or megascoplcally not prominent. This occurs in ail quadrangles shown in figure 1. The essumption is that growth of albite accompanied the development of cleavage.

As previously polnted out, there is strong evidence for neomorphic growth of quartz, chlorite, and muscovite in the slates of the Nartinsburg Formation. Also, the replacewent of quartz and new mineral growth along the borders of quartz grains in graywackes suggest considerable reconstitution due to chenfcal interaction between framework grains and matrix, and probably of the watrix 1tgelf. Thus, there can be little doubt that the slate grew at or near conditions of low-grade reglonal metamorphlom, Judging from the assemblage of new minerals that was produced. It lo not Intent to debate the vague zone of passage from 
lagenesis to metamorph1sm. However, I will suggest later that the cleavage in the Martinsburg forned during the Appalachian orogeny, and, because at that tine the top of the Martinsburg was burled by approximately 24,000 feet of rock ranging in age from Silurian to Pennsylvanian, and the base of the Martinsburg was covered by about 35,000 feet of rock, it was at a terperature of at least $350^{\circ} \mathrm{C}$, assuming a geotherwal gradient of $1^{\circ} \mathrm{C} / 100$ feet. This is well within the temperature range of the greenschist facies of metamorphism. It is known that depth of burial alone probably cannot be held accountable for metamorphism, but the rocks in eastern Pennsylvania have been severely affected by orogenic deformation.

Further evidence for metamorphism in the Martinsburg is the occurrence of anthraxolite wich Stevens (1966) showed is a metamorphic product, although he belleved that the metamorphism occurred during the Taconic orogeny.

Lack of shearing at sandstone-shale contacts was taken as evidence by Mawell (1962, p. 286) that the sandstones were incompetent during the folding and development of cleavage. However, there is evidence that bedding slip occurred prior to cleavage development ( $\mathrm{flgs} .3,88$ ), and 1t is suggested. that the incompetent behavior of the sandstones and the development of cleavage was due to deformation in a deeply buried sequence of rocks.

These conclusions do not rule out the dewatering mechanism of Maxwell (1962). His mechanism has been applied in other areas 
here 1t was concluded or inplied that slate formed under low-grade metamorphic conditions (Moench, 1966; Clark, 1969; Povell, 1969). Water has long been known to be a contributing factor in the alignient of mineral grains. Fissility due to compaction and some dewatering of muds, is one example. The alignment of minerals due to flowage in sandstone dikes is another well known example. Axial-plane cleavage has been shown to have developed In penecontemporaneous folds forwed by loading under near-surface conditions (Williams and others, 1969). On the other hand, penecontemporaneous slum folds have been shown to occur in flysch basins without the development of cleavere, but with superposition of a later "tectonic" cleavage that is coincidentally parallel to the axial planes of the slurp folds becsuse of the geometry of the basin and directions of tectonic stress (Helwig, 1970). The fact that mineral alignment can occur under conditions of low temperature and pressure does not mean that they cannot occur under metamorphic conditions. The role of water in metamorphism has been anply discussed, ranging from its effects during the development of cleavage (Hills, 1963; Leith, 1905, p. 70) to higher grades of metamorphism (Yoder, 1955). It is to be expected that water is liberated during progressive metamorphism. There is little reason to suppose that such water could not have been the mobility medium during the development of cleavage at elevated temperatures and pressures. 
The possibility therefore exists that the disappearance of cleavage in the Martinsburg near the Shawangunk contact can be attributed to rapid dewatering of the Martinsburg neax the permeable sands of the Shawangunk, thus precluding reorientation of mineral grains acconpanying increased pore-water pressures that approached Ifthostatic pressures. The cleavarge would then be younger than the Shawangunk. However, this argurrent loses some of Its attractiveness because Carson $(10,68)$ shows that sinflar decrease in cleavage development occurs several thousana feet below the top of the Nartinsturg in New Jersey.

Asice froul tineralogical considerations, the bellef that cleavage in the Martinsburg formed diagenetically while the rock was still wet stenmed from the discovery that sandstone dikes parallel cleuvage in at least one locality (Naxwell, 1962, p. 287, 1ig. 4A). The dike pictured by Maxwell diverges a fer degrees in dip from the dip of the cleavage ( $5^{\circ}$ by my measurement). Maxwell attributed this to intrusion of the dike early in the folding and presumably reorlentation of the cleavage to its present gentlex position later on in the folding. However, more difficult to explain is the pact that the strike of the dike (H. $28^{\circ}$ E.) differs from the strike of the cleavage (N. $48^{\circ}$ E.) by $20^{\circ}$ ! This iuplies considerable reorlentation of stress which may not be compatible with the mechanisw as envisioned by laswell. The dike would have had to be intruded early along cleavage, then lithified while the Tuds were still wet and mineral grains reorlented along the subsequent new stress directions. 
Mud dikes are perhaps more numerous than sandstone dikes in the Martinsturg. One sample collected near the sandstone-dike locality described by Naxwell intrudes fine-grained graywacke for a distance of at least 3.5 inches ( $\mathrm{fig} .92$ ). There is mineral aligrment parallel to the dike wells, as seen in thin section, and the slaty cleavage in the rock lies at nearly right angles to the mud dike. The mud dike extends in many directions that are not parallel to the regional cleavage. Proof that the dike was intruded prior to the development of regional cleavage is found in the fact that the cleavage produced by rolnexal alfonment parallel to the dike walls is crinkled by the regional cleavage (fig. 93). Some neocrystallization has occurred paraliel to the regional cleavEge, but not parallel to dike-wall cleavage. Thus, the question arises, could the sandstone dike in the Martinsburg that is 1llustrated by Maxwell have been intruded before lithification and later have been rotated nearly parallel to the reglonal cleavage in the Martinsburg pelites during tectonism? Sinilar reorientation of early sedinentary features into near parallelism with later developed cleavage has been described by Wise (In Field Conference of Pennsylvania Geologists, 1960, p. 65).

The contention of Maxwell that the cleavage in rocks younger than the Martinsburg is "fracture cleavage" needs no further discussion because I have shown that the cleavage is best termed slaty cleavage. 


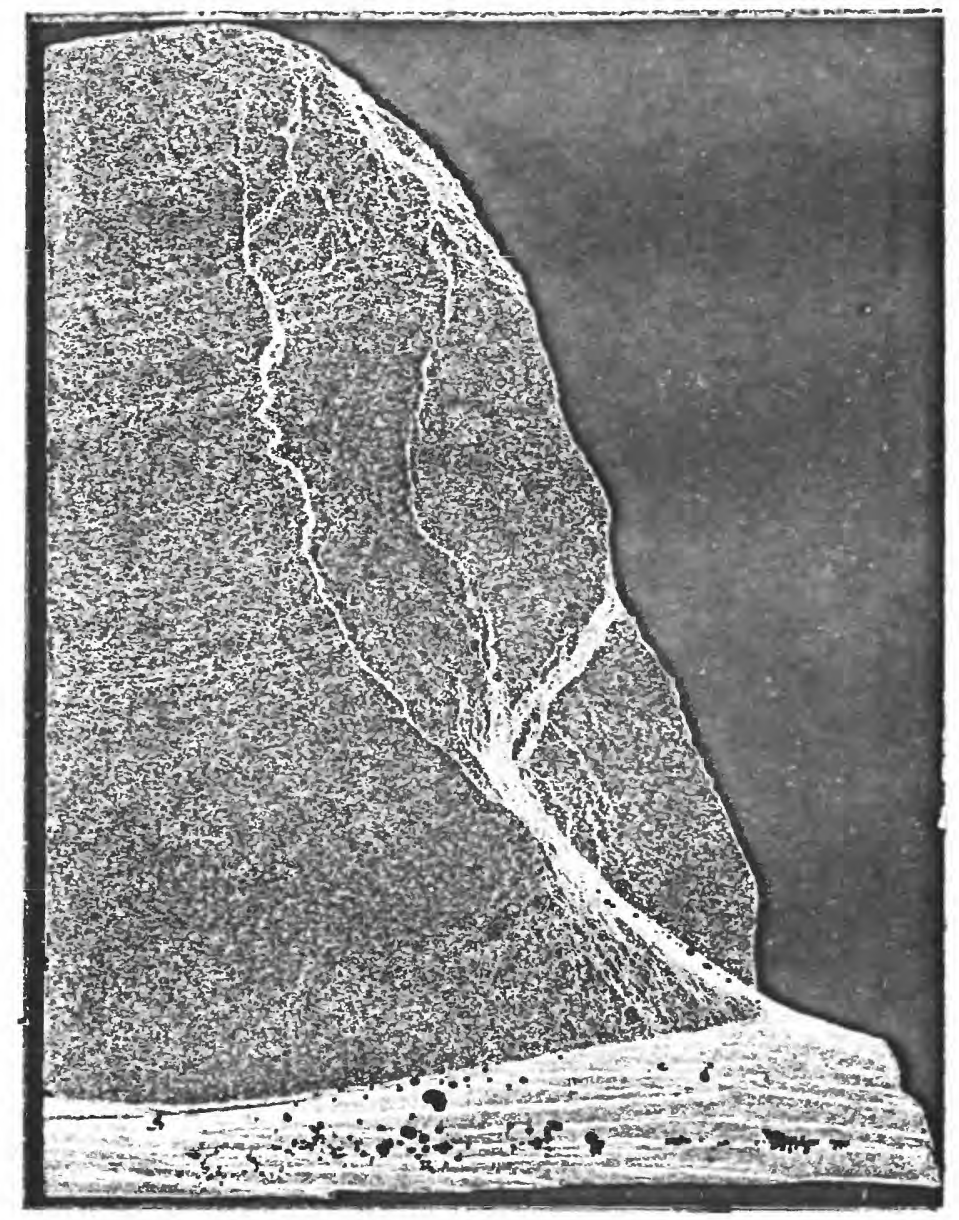

Figure 92. Nud dike (I1ghter vertical structure) intruded into laminated to thin-bedded, fine-grained, calcareous, feldspathic graywacke. Note archinz of laminae in the graywacke in places near the dike, presurably due to arching during intrusion of the dike. A cleavage, not apparent in this photo, has developed by orfentation of minerals parallel to the dilse walls. A later slaty cleavage appears as white lines in the slate at the bottom. Th1s slaty cleavage is refracted to steeper angles in the graywacke and crinkles the mud dike (see fig. 93), showing that it is post-dike in age. Sample from the Rameeyburg llember of the Martinsburg Fortation, 2 inlles southeast of Columbia, N.J., Portland $7 \frac{1}{2}-$ minute quadrangle. Negative print of acetate peel ( $\left.x_{2} 2\right)$. 


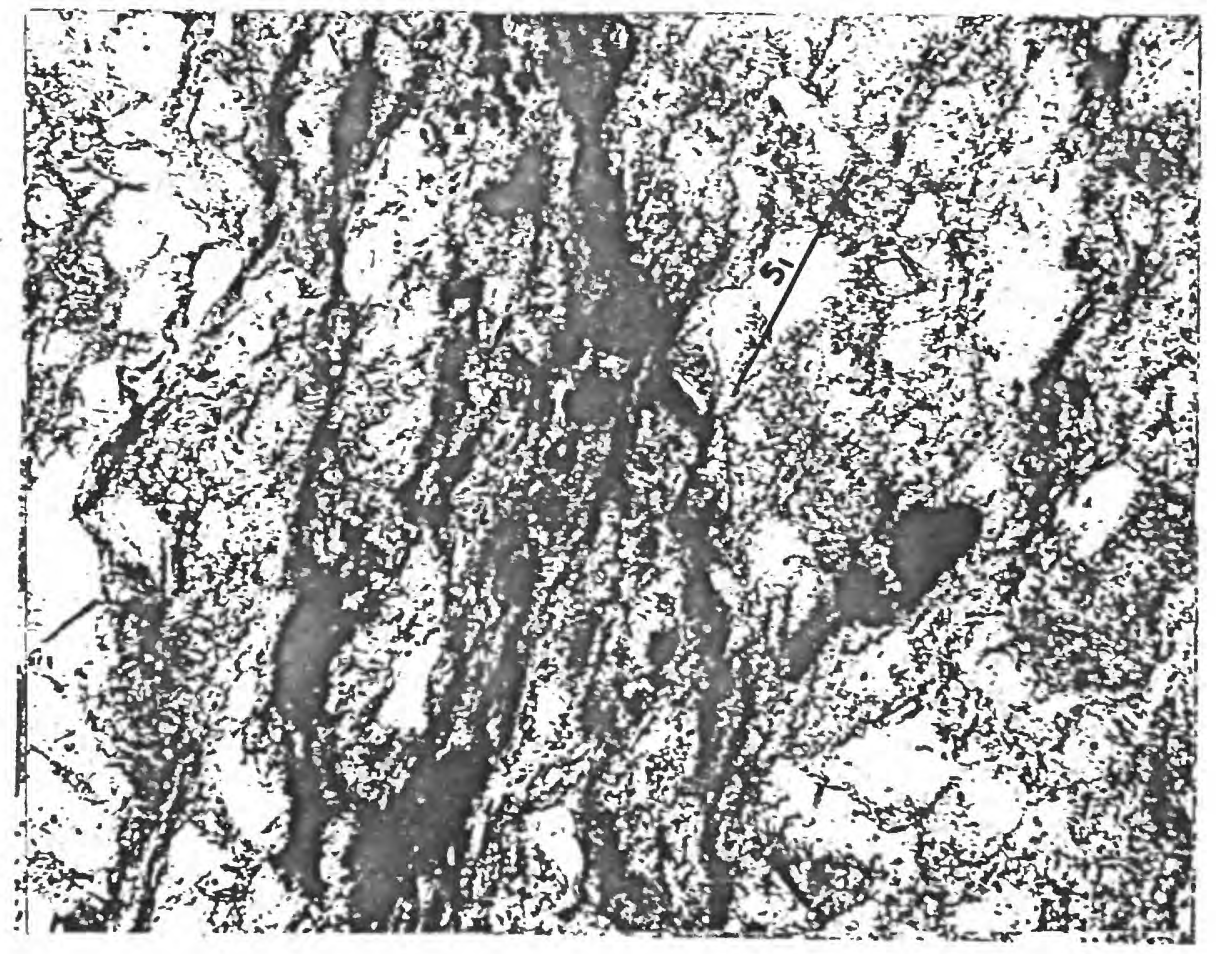

Fibure 93. Photomicrograph (plane-polarized light, $X$ 108) of mud dike (dark vertical lines) shown in figure 92 , offset by slaty cleavage $\left(S_{1}\right)$. An earlier cleavage has developed ty mineral orlentation psrallel to the dike walls, but this is not apparent in the photograph. Sample locality sane as for figure 92. Photograph is reversed (mirror image) in relation to figure 92, top is to upper left. 
Ueavege In Ifthotectonic Unit 2

The Shawangunk Formation, making up the basal part of lithotectonic unit 2, contains only subordinste atwounts of pelitic raterial, and as a consequence, slaty cleavage is not readily apparent. Because of the high content of quartz, cleavage in siltstone of this formation is generally irregularly developed (fig.12). Sandstones show evidence of recrystallization ( 1 fg. 22) and neocrystallization parallel to the regional clearage alrection ( 1 ig. 24). Quartz grains have peripheral growth and interlocking contacts. Commonly cleavage is strongly reoriented around quartz clusters (fig. 94). In places where cleavage folla have intruded quartzose laminae the quartz has recrystallized and stretched to lengths more than 8 times their widths (fig. 95). Such elongate grains are not as vell developed in the underlying Martinsburg. Slip cleavege was not seen in outcrop (often incipient development of slip cleavage is overlooked in the fleld), but it was seen by chance in thin section ( 118.96 ). Note that there is strong evidence that quartz has been replaced by muscovite during the development of slip cleavage. Growth of new quartz in cleavage planes next to other grains is commonly seen in thin sections of the Shawangunk. Clearly, even though the "competent" rocks that make up the Shawangunk Formation did not favor cleavage development, the effects of the process that produced the regional cleavage are recognizable. 


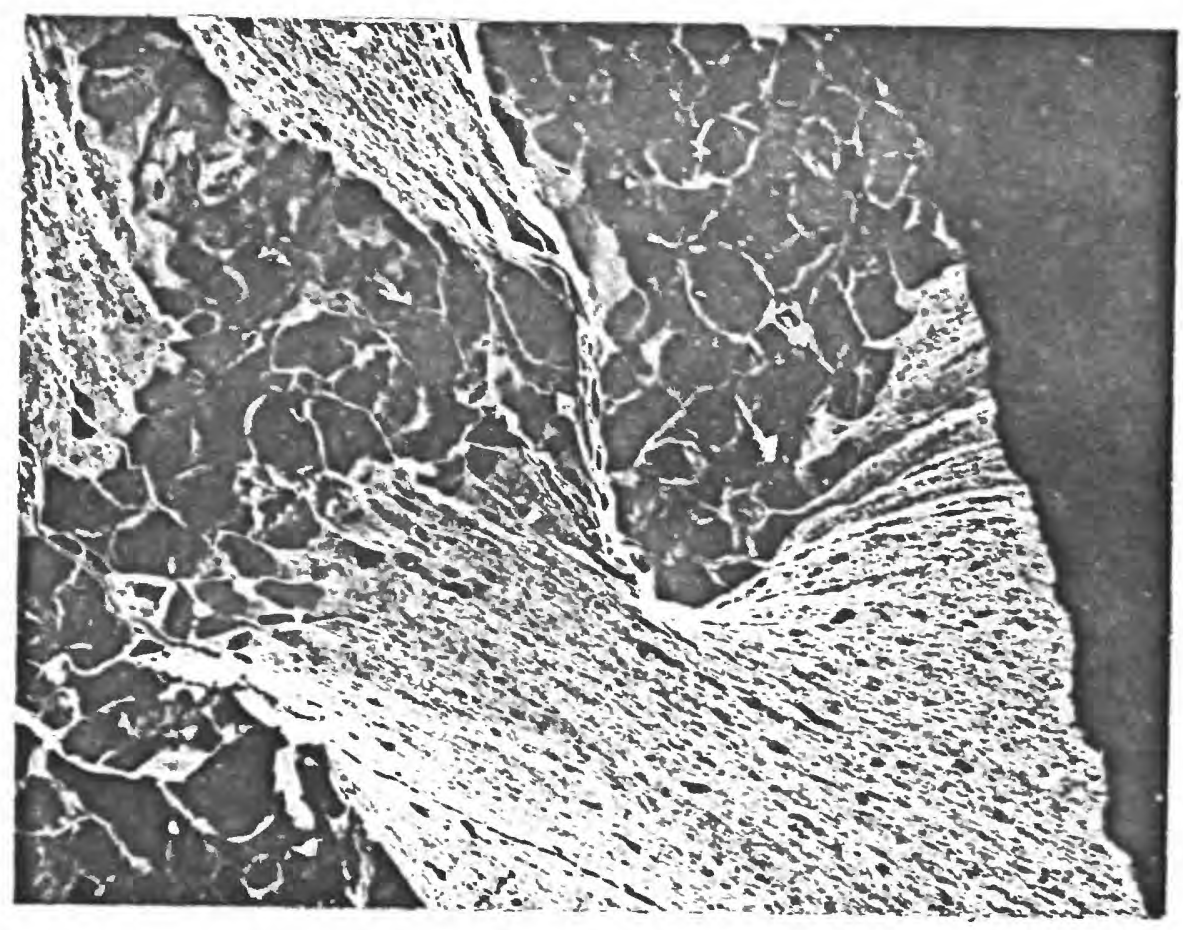

Figure 94. Negative print of thin section ( $x$ 37) showing strong divergence of cleavage in silty shale around irregular lens of medium-grained sandstone. Note the continuation of cleavage and intrusion of cleavage folla through the sandstone. Clinton Member of the Shawangunts Formation, Delaware Water Gap, N.J. 


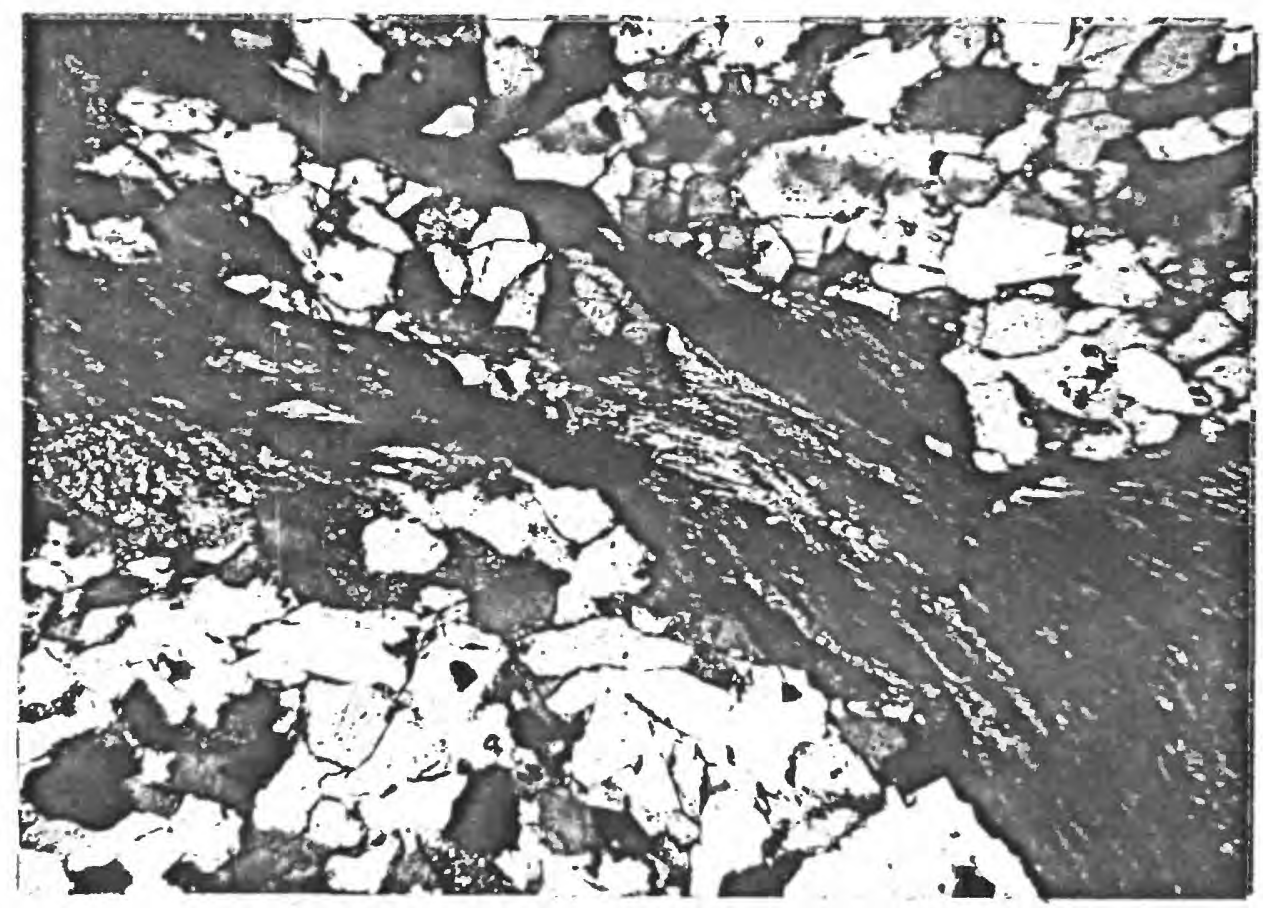

F1gure 95. Photomicrograph (crossed polarizers, X 43) showIng cleavage folia passing through a sandstone lamina between two silty shale lenses. The quartz grains (light area) "caught" in the cleavage are stretched into slivers that are more than 8 times their width. The original shapes of the quartz grains are shown above and below. The needle quartz is intergrown with minute muscovite shreds lying parallel to cleavage. A linear granoblastic texture has developed due to stretching, granulation, and recrystallization. Clinton Member of Shawangunk Formation, Delaware Water Gap, N.J. 


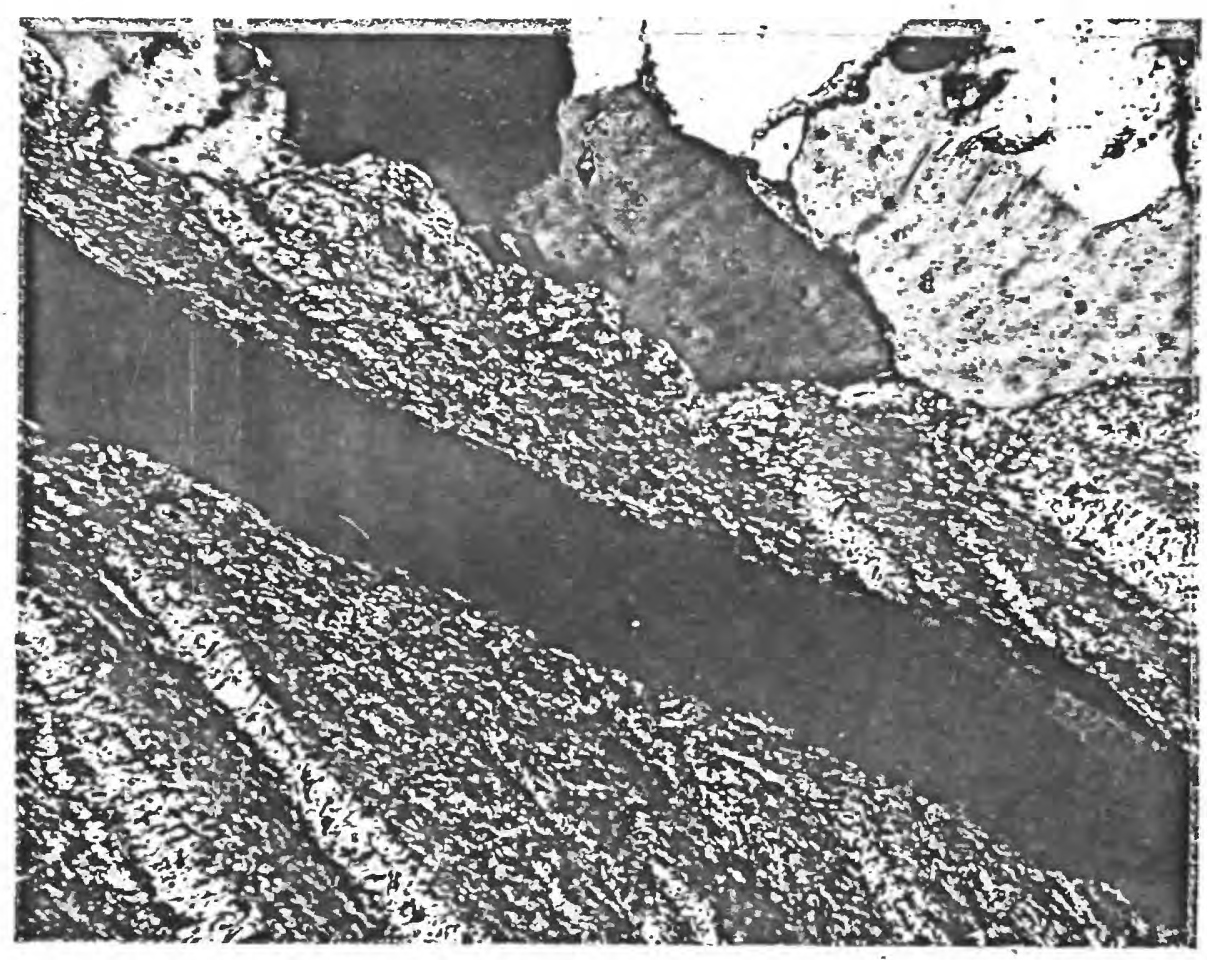

Figure 96. Photomicrograph (crossed polarizers, X 180) showing slip cleavage (kink bands extending to lower right) in shale of the Clinton Member of the Shawangunk Formation, Delaware Water Gap, N.J. Note solution of quartz grains parallel to tops of small kinks and growth of small grains of muscovite (about 0.007 mon long) replacing quartz (at arrow). Dark band in center is crack in thin section. 
Cleavage in the Bloomsburg, which contains larger amounts of finer grained rock, 1s more apparent (f1g. 25). In figure 26, the alignment of micas parallel to cleavage planes is not apparent because the photograph was taken in plane-polarized light. Figure 97 shows an enlarged section of the same thin section under crossed polerizers. The alignment of muscovite and elongation of some quartz parallel to cleavage is more apparent.

\section{Cleavage In Lithotectonic Unit 3}

Megascopically, slaty cleavage is very apparent in shales and siltstones of Iithotectonic unit 3 (figs. 50, 98). Crush quartz is conmon in most thin sections of rocks from the unit as is neomorphic growth of muscovite, quartz, chlorite, and clacite (figs. $29,40,49,99$ ). Needle quartz has developed parallel to cleavage in some samples; length:width ratios in these may exceed $35: 1$ (11g. 100). Examples of laminar intrusion of pelitic waterial along cleavage folia are numerous in laminated and finely bedded rocks ( 1 Ig. IOI). Evidence that the cleavage formed after the rocks were lithified to some degree is afforded by cleavage cross cutting shells (fig. 102), stylolites (fig. 103), and beddingplane slickensides (see Epstein and Epstein, 1969, 11g. 65A). Many mid cracks are present in rocks in lithotectonic unit 3; these are all extended in the $\underline{b}$ tectonic direction. Slaty cleavage is preferentially concentrated in those mud-crack colurans that are subparallel to the bc plane ( 1 ig. 104) giving the impression in some fases that the features are not mud cracks, but intrusions of 


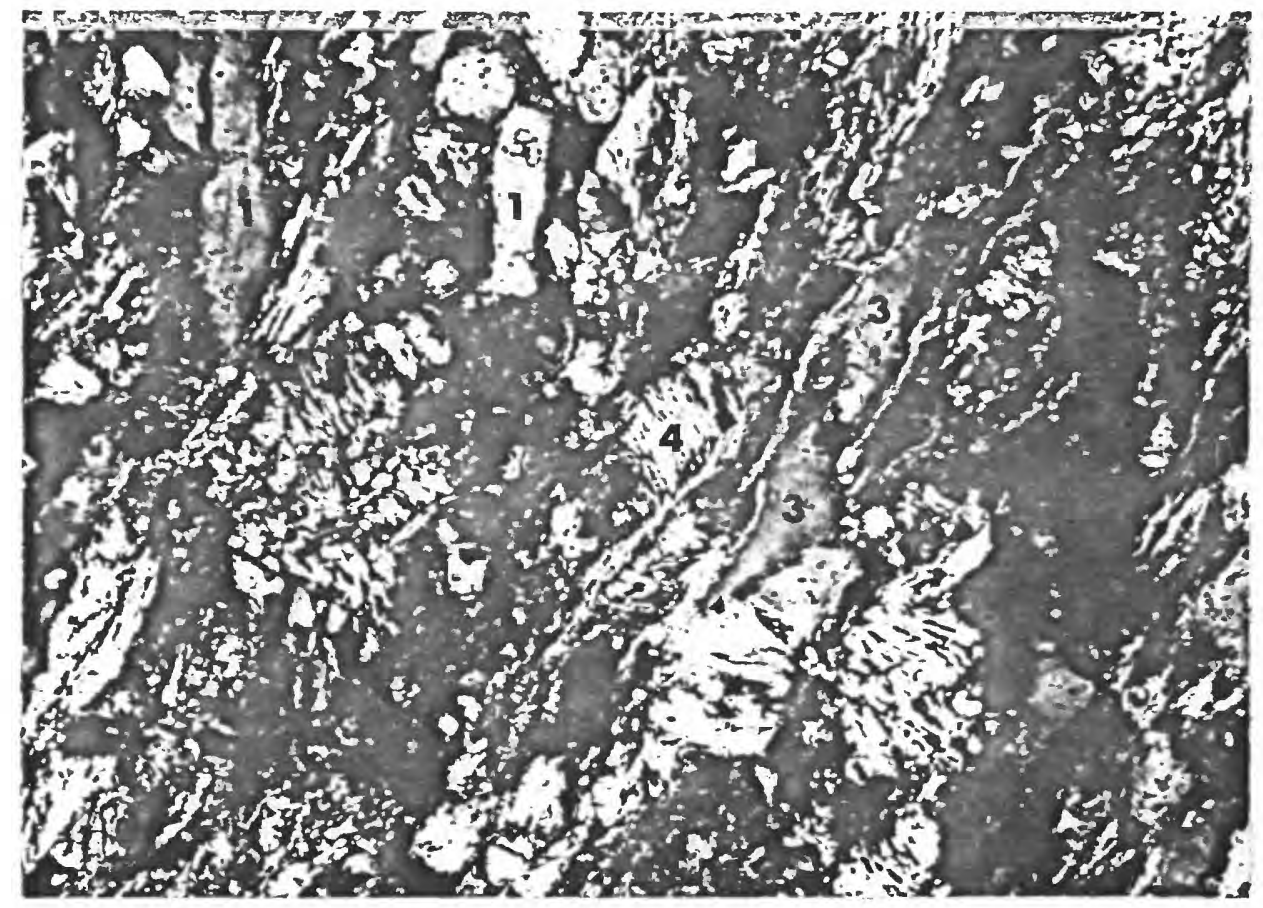

Figure 97. Photomicrograph (crossed polsrizers, X 270) of coarse siltstone to very fine grained graywacke (see f1g. 26) showing alignment of muscovite along cleavage extending to lower left, quartz graing (I) paraliel to bedding that is vertical in photograph, corrosion and new wineral growth along edges of quartz (crush quartz) in the plane of the cleavage (at 2) so that some quartz is oriented subparallel to cleavage (3). Note dragging of muscovite into cleavage (4) and diminution of muscovite in cleavage folia. Bloomsburg Red Beds, 0.5 mile northwest of Dunnfield, N.J., Delaware Water Gap. 


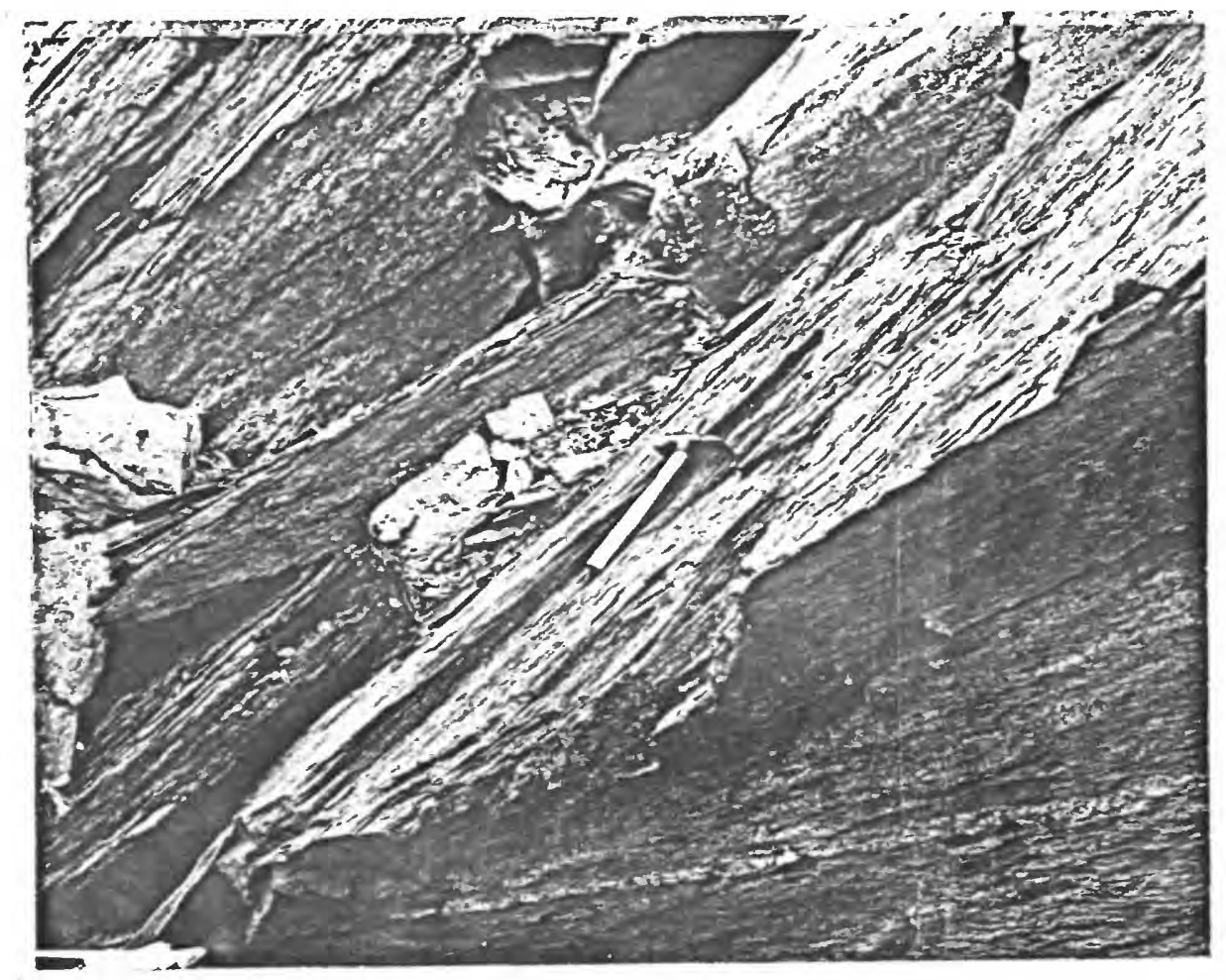

Figure 98. Prominent slaty cleavage dipping to the southeast (parallel to hamer handle) in the Port Ewen Shale, Godfrey Ridge, 0.9 mile northwest of tollgate on U.S. Interstate 80 in villege of Delaware Water Gap. More gently dipping bedalng is apparent on jolnt in lower part of photograph. 


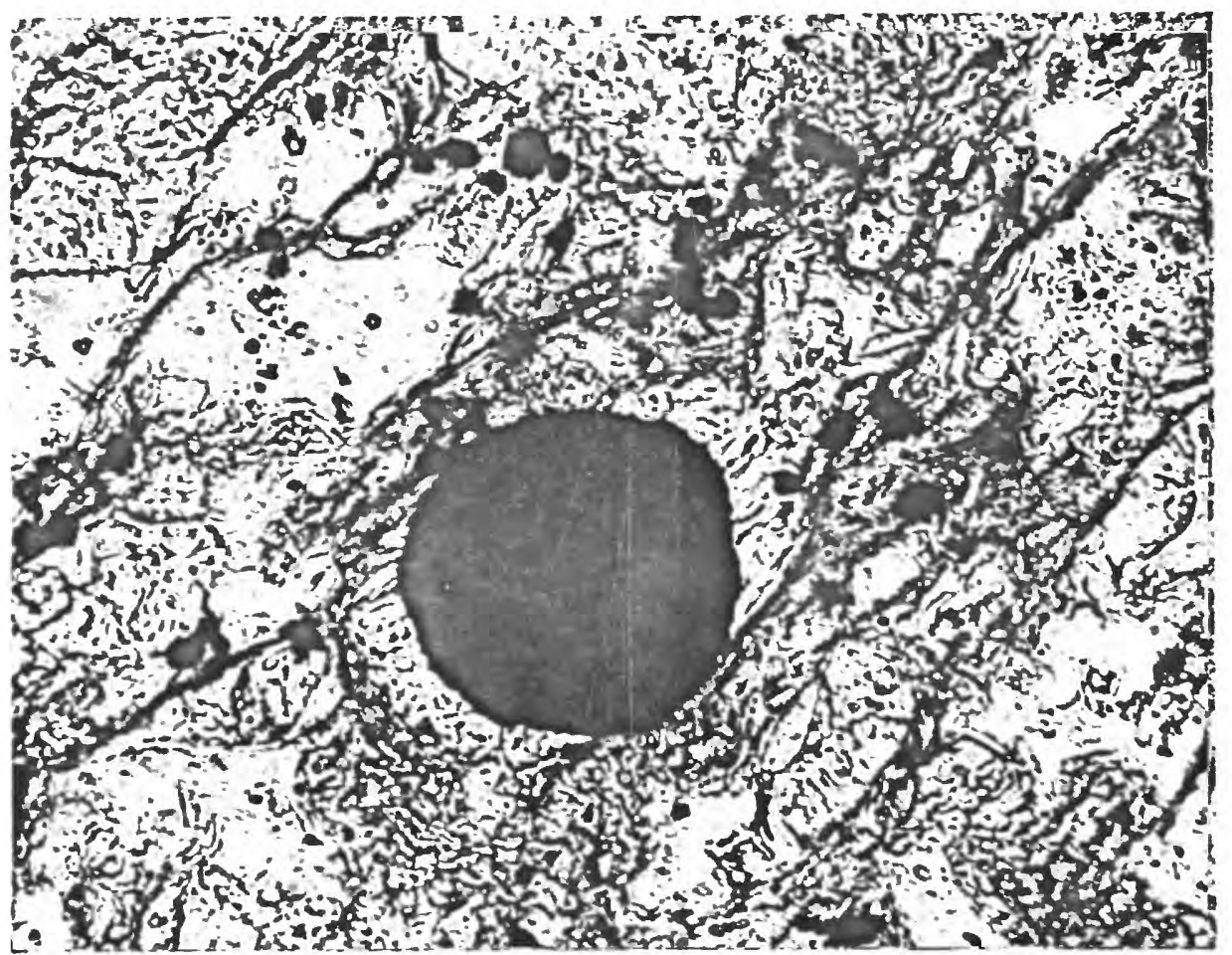

F1gure 99. Fhotomicrograph (plane-polarized light, X 430) showing growth of quartz and lesser chlorite and muscovite paraIlel to slety cleavage (trending to lower left) in pressureshadow areas around pyrite grain. Corroded quartz grains are jagged along edges perpendicular to cleavage (crush quartz). Note warping of cleavage folla around quartz. Bedalng is horizontal. This is an enlargerent of figure 40. Port Eten Shale, unit 3 of measured section 7 . 


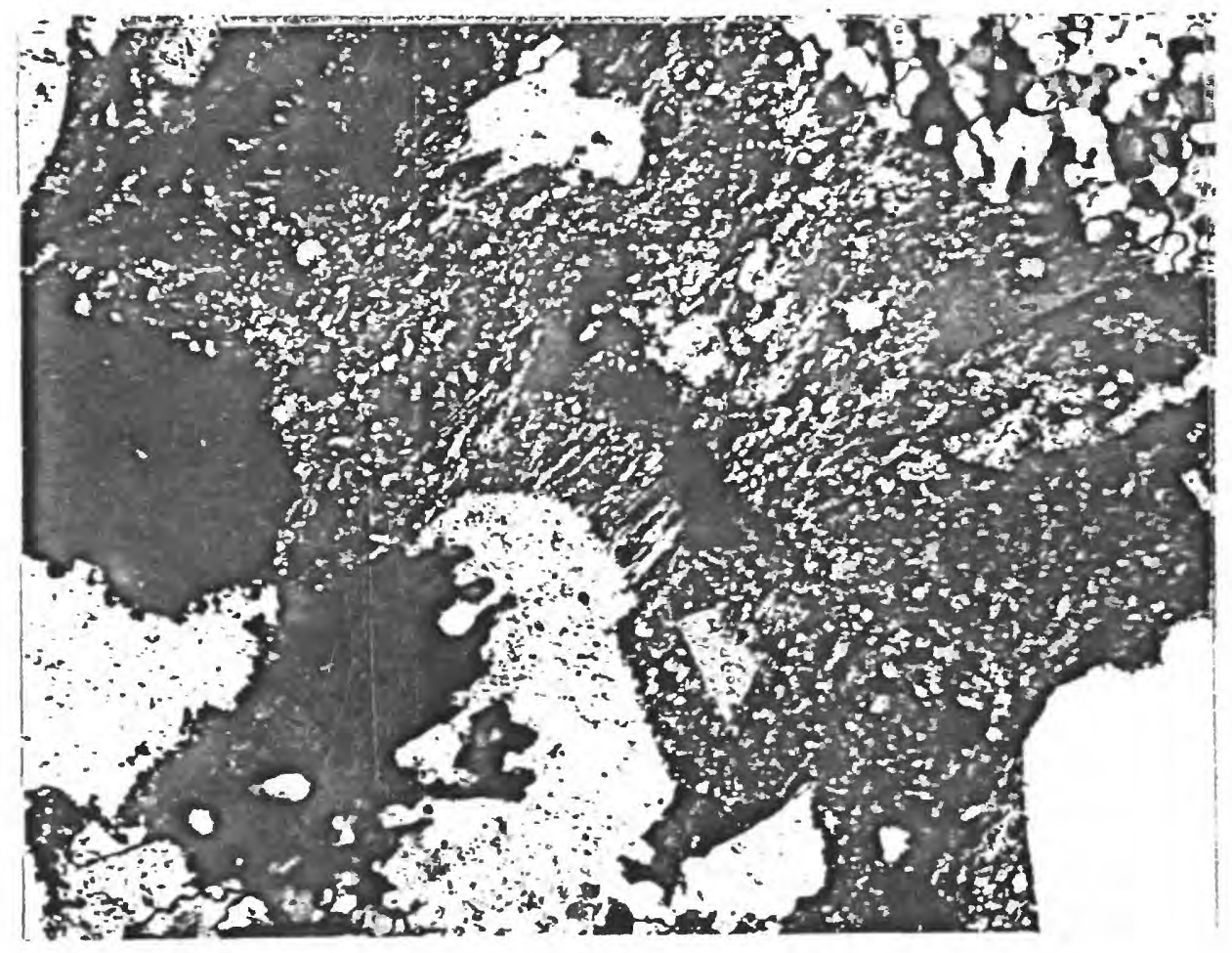

Figure 100. Photomicrograph (crossed polarizers, X 87) of needle quartz and muscovite, parellel to cleavage $\left(S_{1}\right)$, extending from corroded edges of quartz grains in very coarse grained sandstone in the Shriver Chert of the Oriskany Group, unit 19 of measured section 7. Soine of the needle quartz is more than 35 times longer than it is wide. A milmentary granoblastic texture has developed in some areas. See figure 44 for I1thologic detalls. 


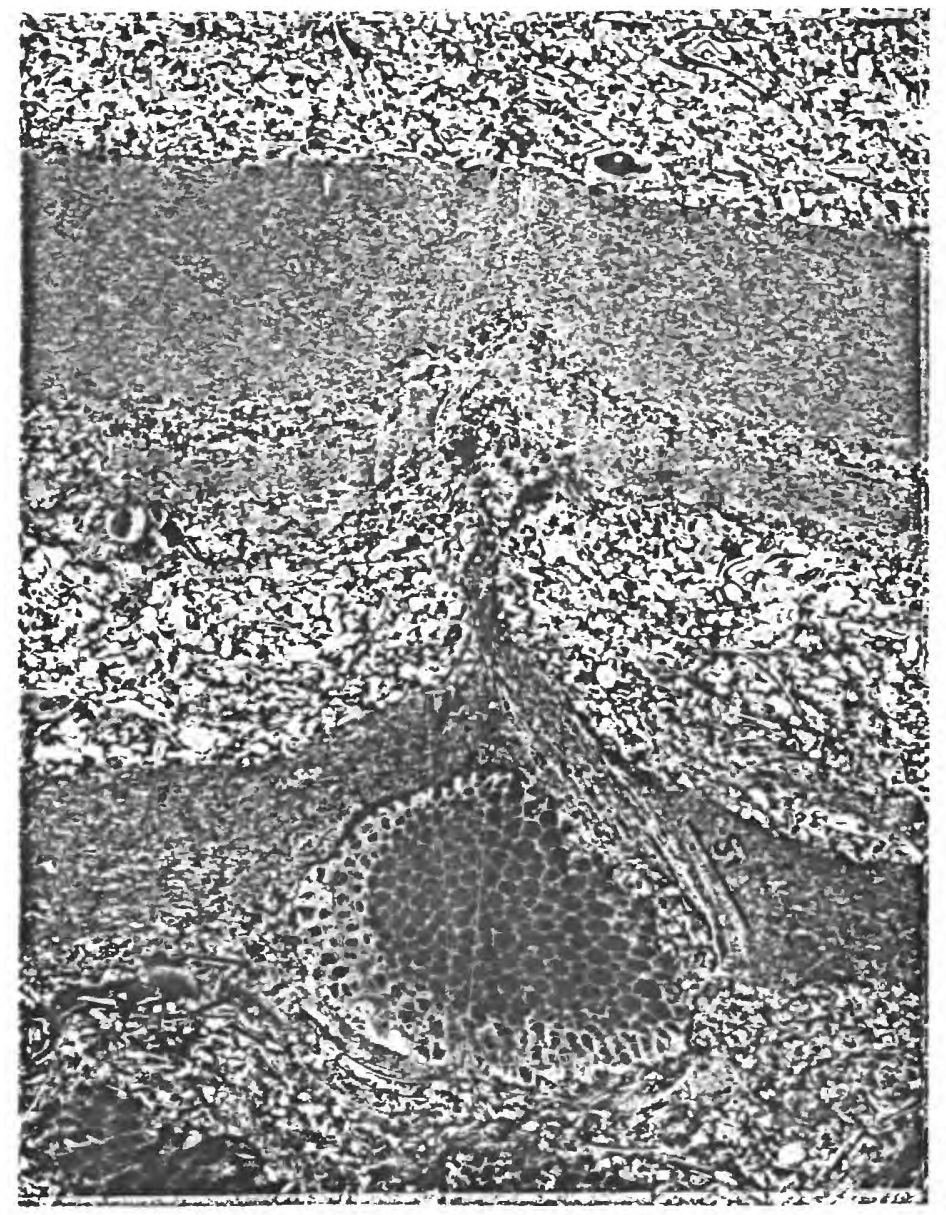

Figure 101. Negative print of thin section (X 9) showing Intrusion of elongate calcite and quartz along cleavage folla $\left(s_{l}\right)$ into biopelmicrite (dark lamina) and arching of biopelmicrite. Note divergence of cleavage around Coenites sp. Arrows mark places where quartz and calcite have grown subparallel to cleavage. Uppermost Bossardville Limestone, quarry of Hamilton Stone Co., Inc., Bossardsville, Pa., Saylorsburg $7 \frac{1}{2}$-minute quadrangle, unit 23 of measured section 18 of Epstein and others (1967). 


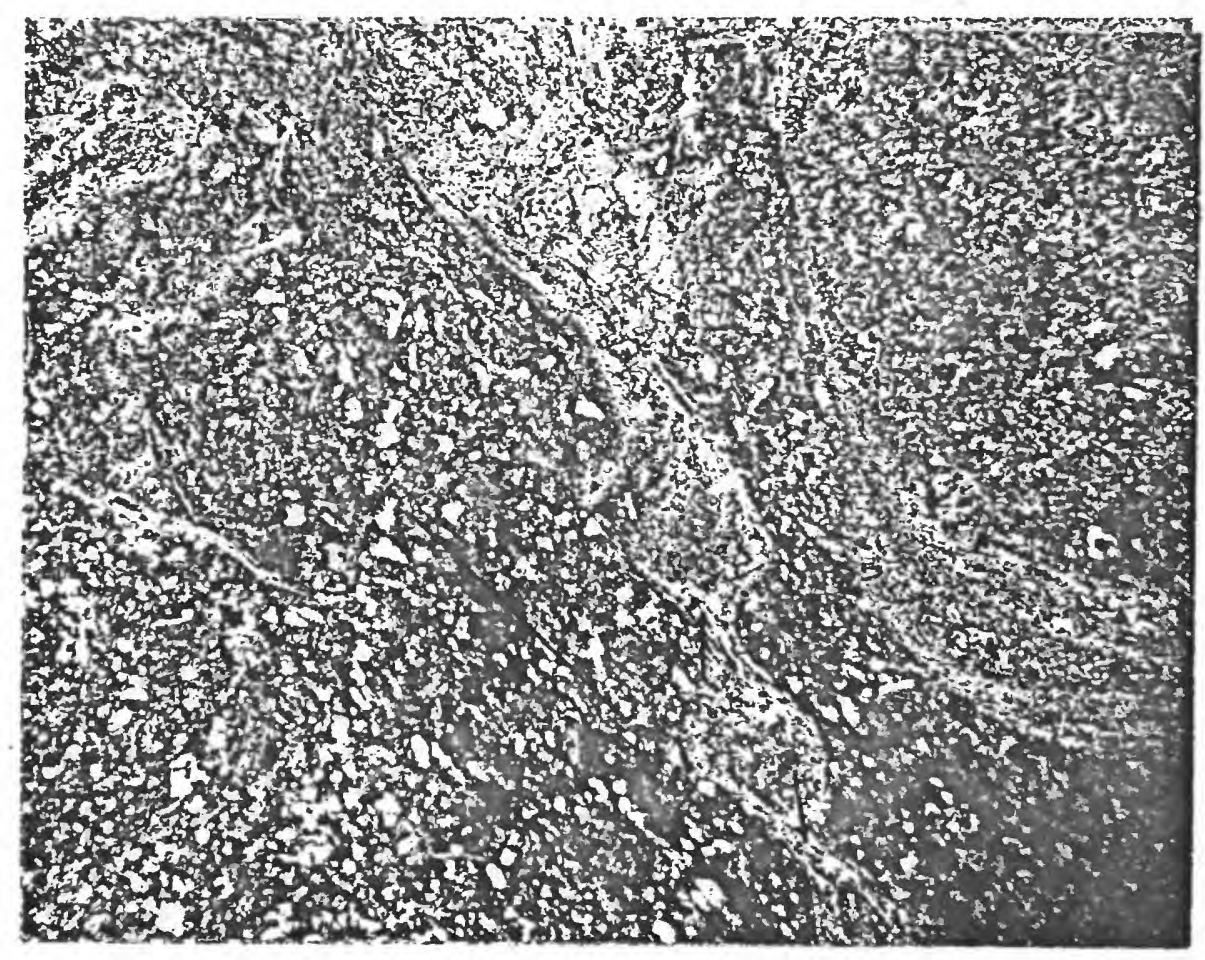

Figure 102. Photomicrograph (plane-polarized Iight, X 44) of very fine grained fossillferous calcareous sandstone of the Schoharie Formation with cleavage $\left(S_{1}\right)$ defined by aligned quartz, calcite, and minor muscovite, cutting across brachiopod shell. Elongate quartz has grown where cleavage cuts across the shell (arrows). Sample from roadcut along U.S. Route 209 near Buttermilk Falls, East Stroudsburg $7 \frac{1}{3}$-minute quadrangle. 


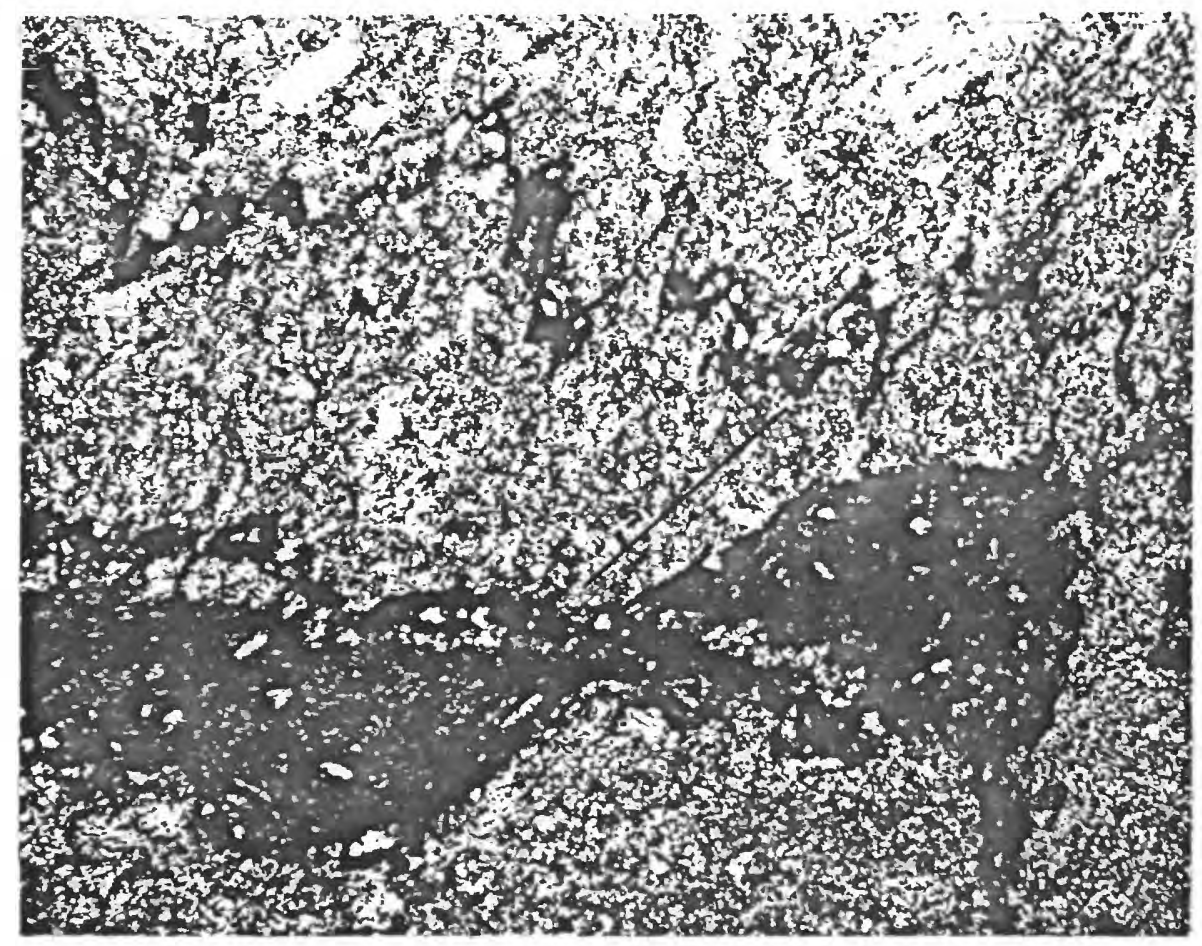

Figure 103. Photomicrograph (plane-polarized light, X 44) of stylolites (Irregular dark seams) cut by cleavage $\left(S_{1}\right)$ in silty fine-graincd Iimestone. Shriver chert of Oriskany Group, roadcut along U.S. Interstate $80,0.5$ mile west of Minisink Bills, $\mathrm{Pa}$. 
Figure 104. Deformed mud-crack polygons in laminated dolomite (A, same as fig. 33) that have been shortened in a northwest direction with a length (parallel to b):width (parallel to a) ratio averaging about 1.8:1. Coordinate axes are shown: a, direction of tectonic transport; $b$, direction of fold axes; $c$, perpendicular to ab plane. B, C, and $D$, are negative prints of acetate peels showIng more pronounced development of cleavage and intrusion of pelItic material along columns that are subparallel to $\underline{b}(B, a b$ plane; C, ac plane) and lack of intrusion along clesvage folia in columns at right angles to $\underline{b}(B$, arrow; $D$, bc plane). Whiteport Dolomite Member of the Rondout Forwation, roadcut on north side of Cherry Valley Road, 2,000 feet northeast of church in Stormville. 


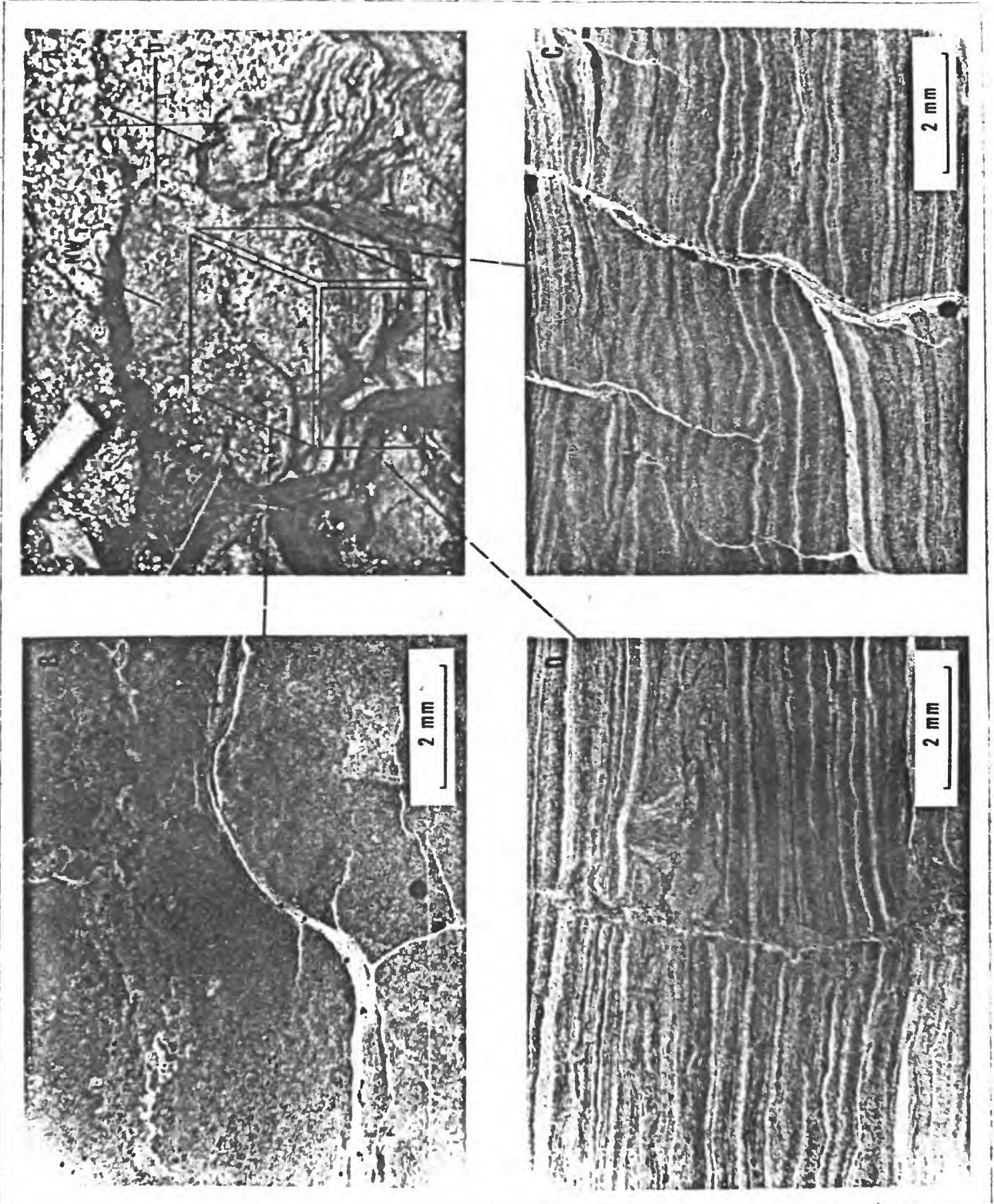


pelitic material along cleavage. Intrusion of some waterlal has taken place along the cleavage, but it was the original columns that localized this movement.

Slip cleavege is rare in the unlt, although many examples could have been overlooked. One locality where slip cleavage 18 present 18 in the Mashlpacong Member of the Rondout Formation on Godfrey Ridge (Plg. 105).

\section{Cleavage In Lithotectonic Unit 4}

Cleavage is poorly developed in the Narcellus and kahentango formations (figs. 54, 55). It is faint in thin section and resembles the cleavage in the Martinsburg Formation near the contact with the Shawangunk Formation. Very little growth of new minerals has been observed in pressure-shsdow areas. Most grains of pyrite seen in the Marcellus in thin section do not have any new mineral growth around them in the cleavage direction. The wost obvious effect these grains have had on cleavage is the typical diverging of cleavage around them. It thus appears that there is a "tectonite front" (Fellows, 1943) between lithotectonic units 3 and 4 in this area. Farther southwest, however, cleavage is better developed so that in the Lehigh Gap area the Nahantango Formation has been quarried for slate, a fact noted many years ago by Dale and others (1914, p. 108) and Behre (1933, p. 119). Thus, the tectonite front crosses the boundary between Iithotectonic units 3 and 4 somewhere between Delaware Water Gap and Lehigh Gap, probably near the border of the Wind Gap and Kunkletown quadrangles 


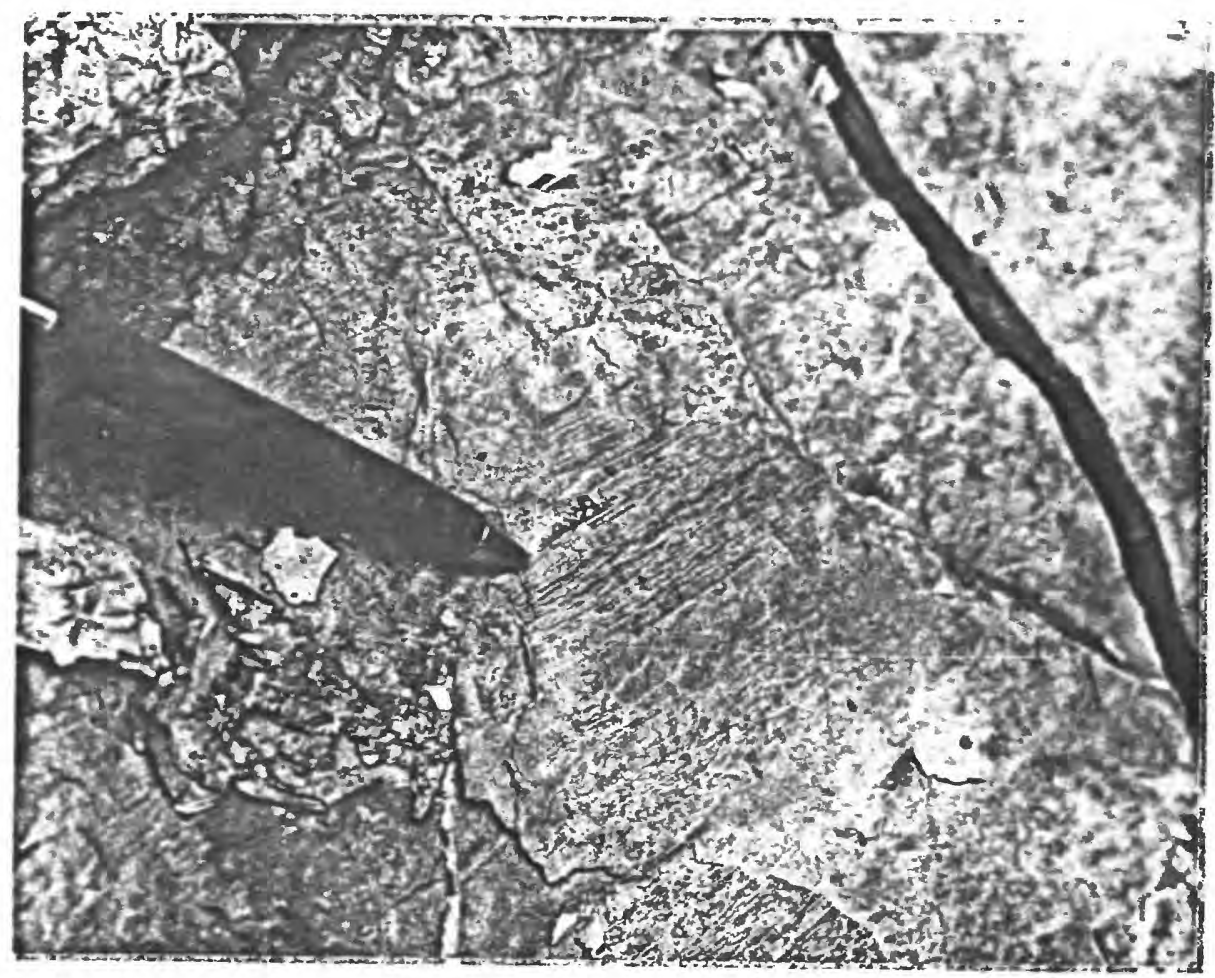

Figure 105. Slip cleavage in the Mashipacong Member of the Rondout Formation crinkling earlier slaty cleavage that dips steeply southeast (toward observer). Attitude of slip cleavage is N. $55^{\circ} \mathrm{E} ., 41^{\circ} \mathrm{NH}$. Intersection of slaty cleavage and slip cleavage is $5^{\circ}$, looking northwest. Outcrop is at an altitude of about 520 feet on Godfrey Ridge, 0.9 mile northwest of the tollgate on U.S. Interstate 80 in the village of Delaware Water Gap, Pa. 
(fig. 1), Judging from the developsent of cleavage in the Marcellus in that area.

\section{Cleavege Sunmary}

In surmary, microscopic study and fleld relations of cleaved rocks suggest that the cleavage in the Stroudsburg area is due to plastic laminar flow of pelftic material along "cleavage" folia accompanied by mechanical reorientation and neocrystallization. The cleavage folia are separated by more quartz-rich folia in which reorientation of platy minerels and dimensional alignment of prismatic minerals has not taken place, or is not as well developed. Numerous lines of evidence point to the conclusion that cleavage developed after the rocks were indurated. Plasticity increased during increased tectonism and the mobility may be ascribed to the presence of water, derived either from connate water squeezed out of the rocks during tectonic compaction, or by release of water from hydrous minerals during continued deformation. Neomorphism of quartz, chlorite, muscovite, calcite, and probably albite, in most rocks, argues for formation of cleavage at and just below the limits of low-grade metamorphism (quartz-muscovitealbite-chlorite subfacies of the greenschist facies). Cleavage 1s progressively more poorly developed to the northwest, and it is probable that cleavage was formed in the youngest rocks (those that were least deeply burled and farthest from the source of stress to the southeast) below the limits of metamorphism. These IIndings disagree with the concept of the origin of cleavage 
developed for the Delaware Water Gap area by Kaxwell (1962) in certain important deta118. His contention that slaty cleavage is not a metamorphic phenodienon affected by extensive deformation of rocks at great depths is challenged. H1s bellef that water facilItated the development of slaty cleavage is accepted. His conclusion that all cleavage in rocks younger than the Martinsburg Formation is fracture cleavage is rejected.

Slaty cleavage is less penetrative (cleavage folia are farthest apart) in rocks that (1) are less pelitic, (2) have not been as severely deformed, and (3) are coarser grained than rocks with wore penetrative cleavage. Every rock examined that has cleavage has at least sotwe mineral allemment parallel to cleavage. Hence, "fracture cleavage," as generally concelved and used by some other workers in the Delaware Water Gap area, is the same a.s and grades into slaty cleavage, and is a term that is inspplicable in this area.

SIip cleavage increases in prominence from southeast to northwest. It consists of kinked follations and transposition of minerals into the new cleavage plane, and in the latter respect is similar to slaty cleavage. It 18 also similar to slaty cleavage In that new minerals may grow parallel to the cleavage direction.

The orlentation of cleavage in all Ifthotectonic units is shown in flgure 86. Cleavage maxima are consistent for all units. The cleavage in the Martinsburg (Iithotectonic unit I) has a slightly wider "spread" than the others, hence the question, what 
is the age of the cleavage (and of the major structural features) in the Nartinsburg Formation and younger rocks in the Stroudsburg area?

\section{Age of Deformation}

The contact between the Martinsburg Formation of Ordovician age and Shawangunk Formation of Sflurfen age has attracted the attention of geologists ever since Rogers (1838) recognized that is was an unconiormity and later proclaimed that the orogeny was the ". . most momentous... revolution" in North America (Rogers, 1858, p. 785). White (1882) described the contact as unconformable at Lehigh Gap, Pa., and Otisville, N.Y., but Chance (in White, 1882) and Lesley (In Lesley and others, 1883) maintained that the angular relations were due to faulting. Later, Clark (1921) and Keith (1923), among others, mintained that the angular unconformity seen between Ordovician and Silurian rocks to the northeast is not to be seen in Pennsylvania.

Miller (1926) disagreed. He believed that an angular unconformity is present in Pennsylvania and based his conclusions on the following reasons: (1) the disconformable relations seen in exposures; (2) sericitized slate pebbles, apparently derived from the underlying Martinsburg, in the basal beds of the Shawangunk Formation; (3) omission of beds along strike; (4) the Martinsburg Formation is more highly metamorphosed than Devonian shales a few miles away; (5) structures in Ordovician and Cambrian rocks are 
more complex than those in Devonian and Silurian rocks; (6) the cleavage in the Nartinsburg, wh1ch was formed during the Taconic orogeny, is itself deformed into folds and was faulted during the Appalachian orogeny.

Behre (1924, 1933) argued that the Taconic orogeny produced slaty cleavage, close overturned folds, and thrust faults and was more intense than later Appalachian deformation which merely distorted the slaty cleavage. Behre (1927, 1933) divided the Martinsburg into three mewbers, a lower and upper slate separated by a sandstone unit. Stose (1930), however, mointained that the upper slate member of Behre is the lower member repeated by fold1ng; hence, the Taconic orogeny must have been intense, for the Shawangunk Formation rests on the lower member of the Martinsburg. Work by Drake and Epstein (1967) reestablished the threefold subdivision of the Martinsburg and showed Store's structural interpretations were wrong.

Willard and Cleaves (1939) showed that the angular unconformity extends as far southwest as Susquehanna Gap in Pennsylvania, where the Bald Eagle Conglomerate of Grabau (1909) rests conformably on top of the Martinsburg Formation. Willard (1938) had previously presented a cross section of the unconformity at Delaware Water Gap, but his interpretation is not in agreement with the interpretation presented in this report.

Hess (1955) belleved that the Taconic orogeny was so intense that it was not only the cause of folding of the sediments in the 
Appalachian geosymcline, but rather the cause of the geosyncline 1tself. Woodward (1957) waintained that the slate belt of the Martinsburg is the result of the superposition of three periods of folding, each having a different trend. Hovever, no fleld evidence has been recognized to support Woodward's views.

Work in the Delaware Valley by Drake and others (1960) led to the interpretation that the Taconic orogeny was more severe than the Appalachian orogeny in that area, that far more complex structural terrane was present to the southwest, and that the slaty cleavage in the kartinsburg is Taconic in age. At the same time, Arndt and Wood (1960) concluded that the Appriachian orogeny was by far the stronger. Wood and others (1963, p. 78) suggested that the discordant contact between the Martinsburg and Shawangunk might be largely the result of faulting. Maxwell (1962) concluded that the flow cleavege in the Martinsburg Formation in the Delaware Water Gap area was produced by relatively minor deformation during the Taconic orogeny.

The recent interpretation that a large nappe underlies the Great Valley in easternmost Pennsylvania (Drake and others, 1961, 1967; Drake, 1967a, 19670, 1969; Drake and Epstein, 1967; Davis and others, 1967) with no structurel counterpart in rocks younger than Ordovician strongly suggests an Intense Taconic orogeny. Nappes have been reported in other parts of the Great Valley (Stose, 1950; Gray, 1954; Field Conference of Pennsylvania Geologlsts, 1966). Root (1970), however, maintalned that the Lebanon 
Valley nappe in the Harrisburg, $\mathrm{Pa}$, area, contains rocks that were deformed during the Taconic orogeny and thrust into their present position during the late Paleozolc orogeny. Bird and Dewey (1970) explatned the Taconic nappes in Pennsylvania in their plate-tectonic model for evolution of the Appalachian orogen, although they were not certain to what extent Alleghenian (Appalachian of this report) deformation affected pre-Silurian rocks.

Thus the relative intensities of the Taconic and Appaiachlan orogenies in eastern Pennsylvania have not been resolved. On the basis of field evidence in the Stroudsburg area, outlined in the previous sections, it is concluded that (1) there is an angular unconformity between the Martineburg and Shawangunis Forrstlons as shown in plate I and described elsewhere by Epstein and Epstein (1969, p. 169); (2) the Taconic orogeny was a period of mountain building, indicated by the clastic wedge overlying the Martinsburg; (3) most of the folding seen in the area, as vell as the associated slaty cleavarge, is Appalachian in age; (4) deformational effects of the Taconic orogeny include the folding that can be seen under the Shawangunk-liartinsburg unconformity and probably the Portland fault; (5) the observed effects of the Appalachian orogeny in this small area are more intense than the observed effects of the Taconic orogeny--however, if the Taconic nappe reported in the Great Valley was atectonitic (no tectonite fabric was developed), then evidence for this nappe rould not be 
present and the Taconic orogeny may have been extremely intense. Work currently in progress by I. B. Alterman, Columbia University, In the Martinsburg outcrop belt from southeastermmost liew York to eastern Pennsylvania, Indicates that in severel localities an earlier cleavage, previously unreported, which has been nearly obliterated by the later defornation, can be 1dentified. I have not seen this cleavage, but if present, then Alterman is correct that this less distinct, earlier cleavage may have developed as an axial-plane foliation in the nappe (I. B: Alterwan, written commun., 1968).

The evidence that the folds and slaty cleavage in the Martinsburg Formation were produced during the Taconic orogeny, as presented by other geologists included deformation of the slaty cleavage and production of slip cleavage during the later Appalachlan orogeny, folding of the slaty cleavage into cleavage 8.rches, the higher degree of metamorphism in the Martinsburg than in younger rocks, occurrence of large nappes and thrust faults in the Martinsburg and not in younger rocks, and occurrence of slate fragments in basal Shawangunk beds. However, acceptance of some of these arguments leads to certain bewildering contradictions. If the structures in the Martinsburg are Taconic in age, then there should be an abrupt structural aiscontinuity, other than the angular unconforwity, at the MartinsburgShawangunis contact. This is difficult to find. Figure 106 is a composite diagram showing the average trends of the major 


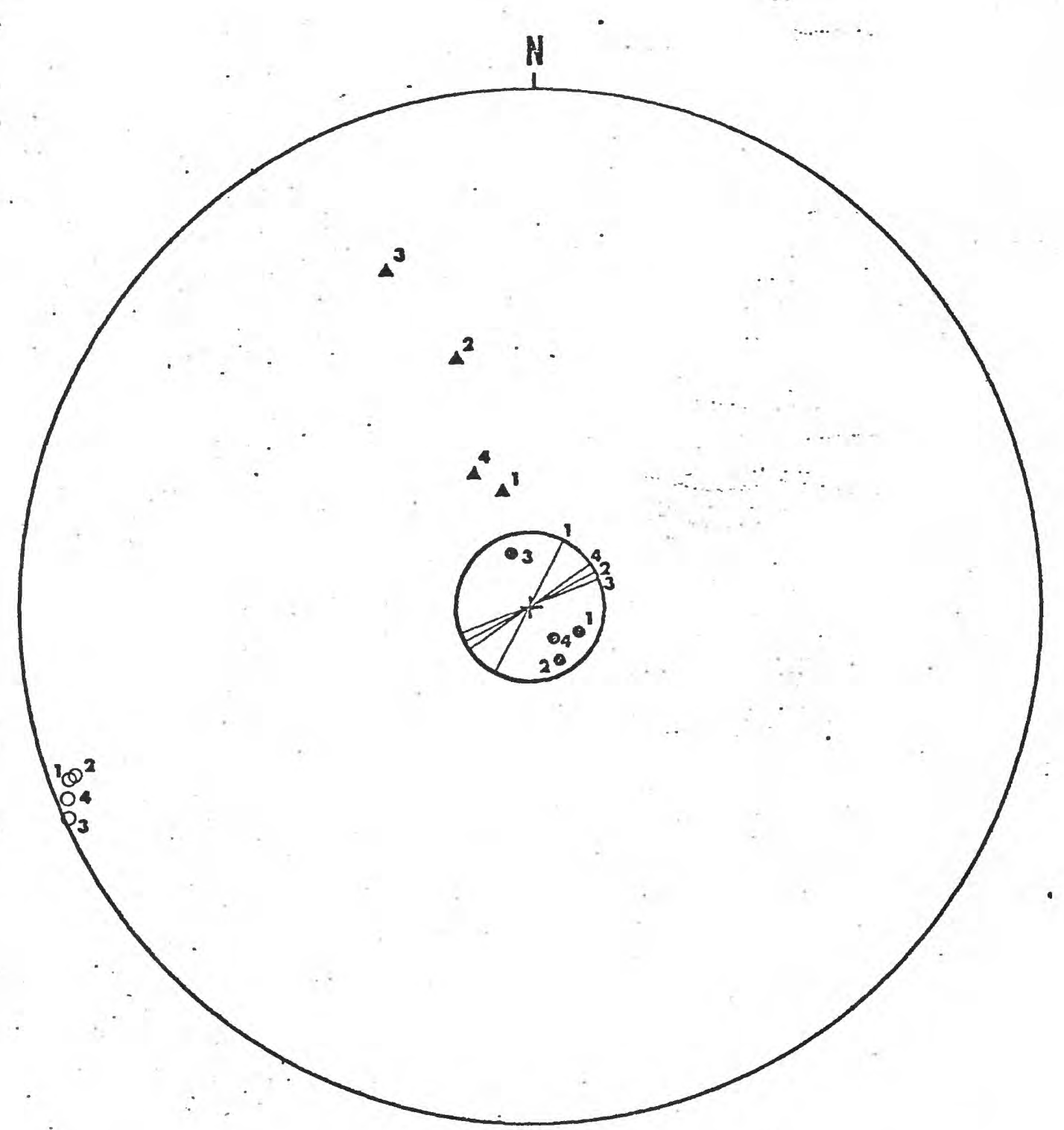

Figure 106. Composite equal-area projections (Iower hemisphere) showing maxitua of poles to bedaing (solid circles), poles to cleavage (solid triangles), intersections of bedding $\left(S_{0}\right)$ and cleavage ( $\mathrm{S}_{1}$ ) (open circles), and average strike of bedaing determined from maxima of bedaing (lines in small central circle) in the four Iithotectonic units (as numbered) in the Stroudsburst quadrangle. 
structual features in the Stroudsburg quadrangle. Note that bedding in Ordovicisn rocks (Iithotectonic unit I) strikes more northerly than in the other units, but ell other structural features, including cleavage, are remarkably similar. This strongly suggests that the Martinsburg was folded prior to Appalachian deformation, but that the cleavage and folds were superimposed on all rocks during the Appolachian orogeny. The formation of slaty cleavage in all rocks in the area at the same time was suggested by Lowry (1957). Thus, if we subtract minor structures of the post-Ordovician rocks from the Kartinsburg, we are left with very little. The slaty cleavage will be gone from the Kartinsburg, as well as the slip cleavage. What remains is a northwest-dipping slightly warped sequence of beds that constitutes the upright Iimb of the nappe that has been mapped to the southeast, and the Portland fault. It is true that there is wore variation in trends of cleavage in the Martinsburg than in overlying units, but this may be expected because the variations, folding of cleavage, and development of a second (sl1p). cleavage increases in the Martinsburg to the southesst toward the center of the orogen.

Moench (1970) suggested that slaty cleavage developed in the Rangeley area, Malne, by tectonic dewatering and mechanical reorlentation of wineral grains in rapidy deposited eugeosynclinal rocks during down-to-basin faulting. He presented the following mechanism for eastern Pennsylvania as an alternative to the mode of cleavage generation I presented earlier (Epstein and Epstein, 
969): the clesvage in the Martinsburg developed during the Taconic orogeny by basinward mass movement, and the cleavage in younger rocks developed later by the same mechanism (sliding basinward on the Blue Mountain décollement). Similar cleavage orientations in the two sequences would then be due to sirflar directions of mass sliding controlled by similar basin geometries. This is a most attractive hypothesis, but it suggests that cleavage in rocks younger than the rartinsburg developed by the dewatering mechan1sm, which Naxwell (1962) originally discounted. Moench's hypothesis, however, meets with several objections. First, it means that stress was taken up in post-Martinsburg rocks w1th little or no effect on the Martinsburg itself (1.e., nearly complete "dermal" tectonics). I have considered this possibility, but discounted it because folds in at least one locality (in the Bushkill quadrangle mentioned previously) pass from one lithotectonic unit into the other. Therefore, there has not been completely independent folding of the two sequences. Secondly, a basin with rapidly deposited muds requisite for Moench's thesis is. not supported by post-Martinsburg paleogeographic interpretations as discussed under environments of deposition.

The tacit acceptance of two orogenies led Broughton (1946) to believe that the slaty cleavage in the Martinsburg of New Jersey was a product of Taconic tectonism and that the slip cleavage was formed during the later Appalachian orogeny, although he suggested that "These structures might well be explained as the result of 
two peaks in the stress cycle of one period..." (p. 17). Because both slaty cleavage and slip cleavage are found in all rocks In the Stroudsburg area, they are herein belleved to have formed during the same continuing perlod of orogeny. This same interpretation has recently been accepted in the Harrisburg. area by Root (1970). The laea that the Martinsburg was severely cleaved during the Taconic orogeny led stevens (1966) to conclude that it was Taconic metamorphism that produced anthraxolite in the Martinsburg, although he noted (p. III) that "It is a curious coincidence that the westward diminution of Taconic metamorphism in the MartInsburg conforms to the pattern of later metamorphism for the Penasylvanian coals."

No unoriented slate fragments have been found in basal Shawanguak beds. Argillite intraclasts in the basal Shawangunk, especially at Lehigh Gap, have cleavage that is parallel to one of two cleavages present in the beds above. Moreover, X-ray analyses Indicate that these fragments are similar to argillites interbedded with coarser Shawangunk clastics and not simllar to slates in the Martinsburg.

The colncidental folding of both the Shawangunk and Martinsburg in the Portland and Bushkill quadrangles several miles northeast of Delaware Water Gap mentioned previously, and the cleavage. In the Martinsburg that is parallel to the axial plane of the fold, is also evidence that the folds and cleavage were produced during post-Shawangunk deformation, the Appalachian orogeny (evidence for 
the Acadian orogeny in this area is scanty).

The sequence of events that can be attributed to Appalachian deformation are still problematical. I presented some of the possibilities in the discussion of I1thotectonic unit 2. The general order of events suggested for most units 1s: (1) uplift and folding by flexural slip; (2) northwest translation of the Ithotectonic units down the regional slope, on décollements, with continued folding and development of cleavage; (3) continued 8lippage in lithotectonic unit 2 with production of bedding slips, wedging, and dragging of cleavage (movement on the décollement zones probably ceased when folds become too tight, for there is no evidence that has been recognized to show that the tight folds in Ilthotectonic units 2 or 3 are faulted); (4) rotation of some of the folds and cleavage, especially in the Martinsburg and older rocks southeast of the Stroudsburg quadrangle and in younger rocks In the Lehigh Gap area, and production of slip cleavage that may be parallel to axial planes of cleavage arches, and small thrusts parallel to the slip cleavage, especially in the Martinsburg. This proposed sequence is only a suggestion gleaned from the field data. Probably all events overlapped to some degree, and the order may have varied depending on local stress conditions. Possibly these events occurred sequentially from southeast to northwest, so that intensity of deformation decreases to the northwest and stages 3 and 4 are not represented in 11 thotectonic unit 4 and stage 4 is not recognized in Iithotectonic unit 3, but is known 
to the southwest in the Lehigh Gap area where recumbent folds with doubly overturned Ilmbs have been described (Epstein and Epstein, 1967, 1969). Effects of differences in 1ithology were probably a strong contributing factor to heterogeneity in deformation from place to place. More detalled petrofabric work would shed much light on the problem.

Finally, elsewhere in eastern Pennsylvania there is evidence for wholesale subaqueous gravity sliding like the sliding that produced nappes in the Taconic area of New England. Many of the regional effects of the Taconic and Appalachian orogenies In eastern Pennsylvania are still unresolved. Many geologists are presently involved with the problem, and hopefully the tectonic interpretations presented here, if correct, will fit into the overall structural synthesis. 


\section{GEOMORPHOLDGY}

Numerous and extensive investigations of wind and water gaps in the Appalachians have contributed to the controversies regarding Appalachlan geomorphic evolution. Many geologists believe that after the Appalachian orogeny the drainage divide between streams that floved southeastward into the Atlantic and those that flowed toward the continental interfor was located either in the crystalline highlends southeast of the present Great Valley or in the Valley and Ridge province. The divide has since shifted westward to its present position in the Appalachian Plateau. The location of the original divide, the means by which the divide migrated, and the process or processes by which the numerous wind and water gaps were formed are problems that need to be considered in any hypothesis that attempts to explain the drainsge developuent of the Appalachians.

Johnson (1931) believed that the original drainage lines were obliterated during a Cretaceous marine transgression and that the present drainage pattern is mainly the result of superposition from a coastal-plain cover. The location of a gap was purely by chance and is not systematically related to any weakness in the ridge, although there may have been local adjustinent to structure. 
Meyerhoff and 01mstead (1936) belleved that the present

drainage descended from the pattern that was established in Permian time which ras controlled by structure and topography produced during the Appalachian orogeny. Hence gaps are found along transverse structures or in the northwest limbs of overturned folds.

. Thompson (1949) argued that the original divide, which lay on crystalline rocks along the Blue Ridge-Reading Prong axis, was unstable because the southeastrard-flowing streams had shorter courses than those that flowed northwestward. As a result, the divide shifted northwestward by normal stream erosion (headward piracy), and the gaps in Kittatinny and Blue Mountains are located at points of rock weekness.

Strahler (1945), who favored Johnson's hypothesis, stressed that the main test substantiating superposition was to show lack of coincidence of gaps and sites of structurel weakness (specifically, transverse faults).

Structural characteristics and features other than transverse faults, however, may influence the resistance to erosion of hardrock ridges. These include, among others: (1) changes in outcrop width, owing to changes of dip; (2) abrupt changes in strike, due to dying out of folds; (3) local weakness of otherwise resistant rocks as a result of the overturning of beds and accompanying shearing; (4) closely spaced joints and strong folding resulting from intense local stress; (5) cross folds and attendant fracturing; (6) thinning of resistant units, which reflects the original 
processes of sedimentation; (7) thinaing or elimination of resistant strata by strike faults; and (8) change in facies.

Detalled structural data from gaps in the Stroudsburg area, presented by previous investigators, generally have been scanty. Detalled mapping of Blue and Klttatlany Mountains and of ridges to the north has shown that there is a correlation of gaps with one or more of the following conditions: (1) steep dips of beds and narrow outcrop widths of resistant units; (2) dying out of folds within short distances; and (3) more Intense folding locally than nearby. The parallelism of the gaps is controlled by prowinent southeast-trending cross-joint sets present throughout the area (PIg. 84).

\section{Gaps in Blue and Kittatinny Mountains}

Blue and Kittatinny Mountains, parts of a single ridge supported by the Shawangunk Forwation, are cut by the following gaps in the study area: Delaware Water Gap, Totts Gap, Fox Gap, and WInd Gap. Figure 107 shows the locations of the gaps and other major physiographic features. Figure 108 shows the distribution of geologic formations and the structural geology in the area, and demonstrates the correlation of gap location with the three structural conditions wentioned above.

\section{Delaware Water Gap}

Many early observers of Delaware Water Gap belleved that it was the result of a violent cataclyst. Interesting excerpts of these early discussions are reported by Miller and others (1939, p. 139- 


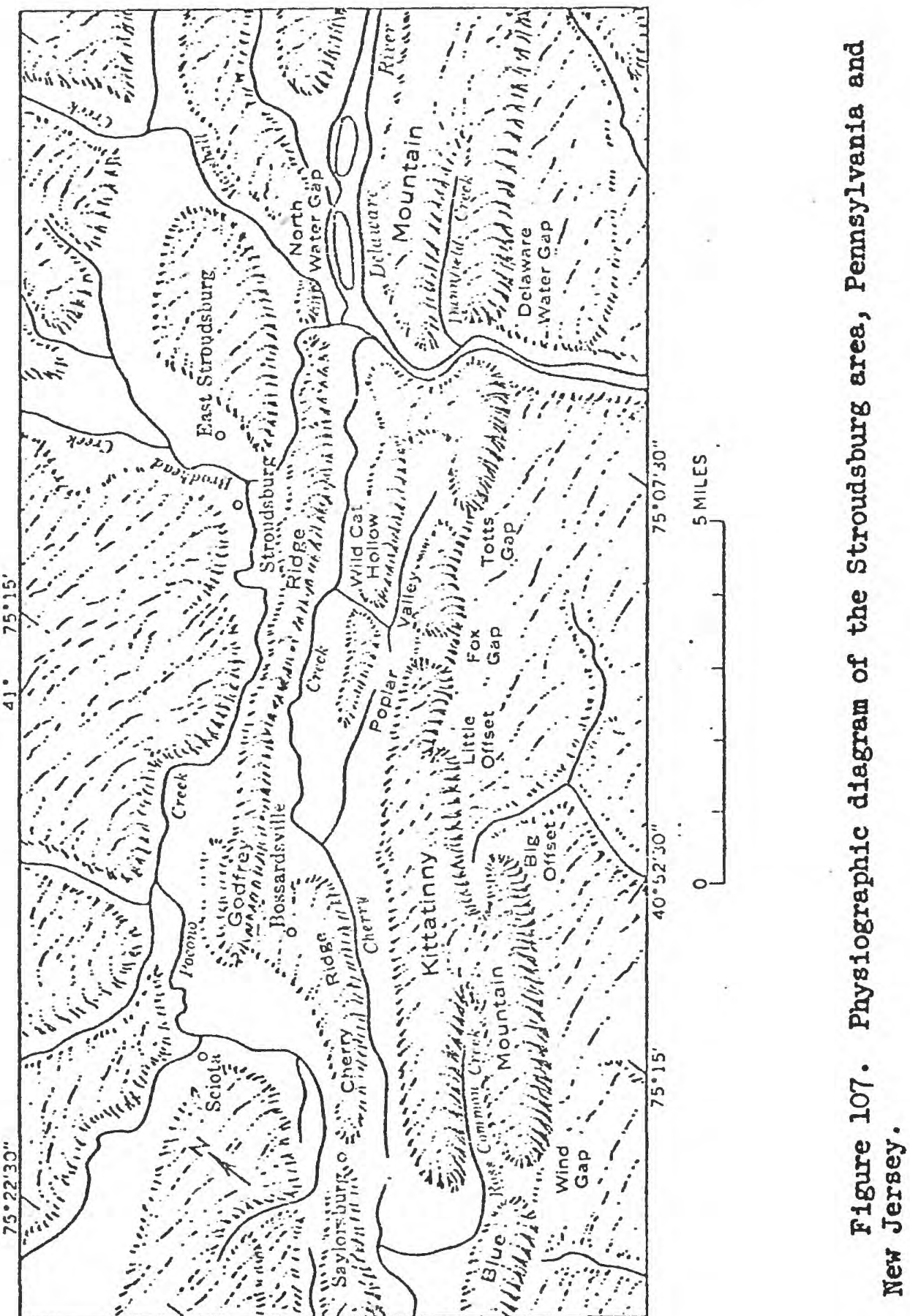



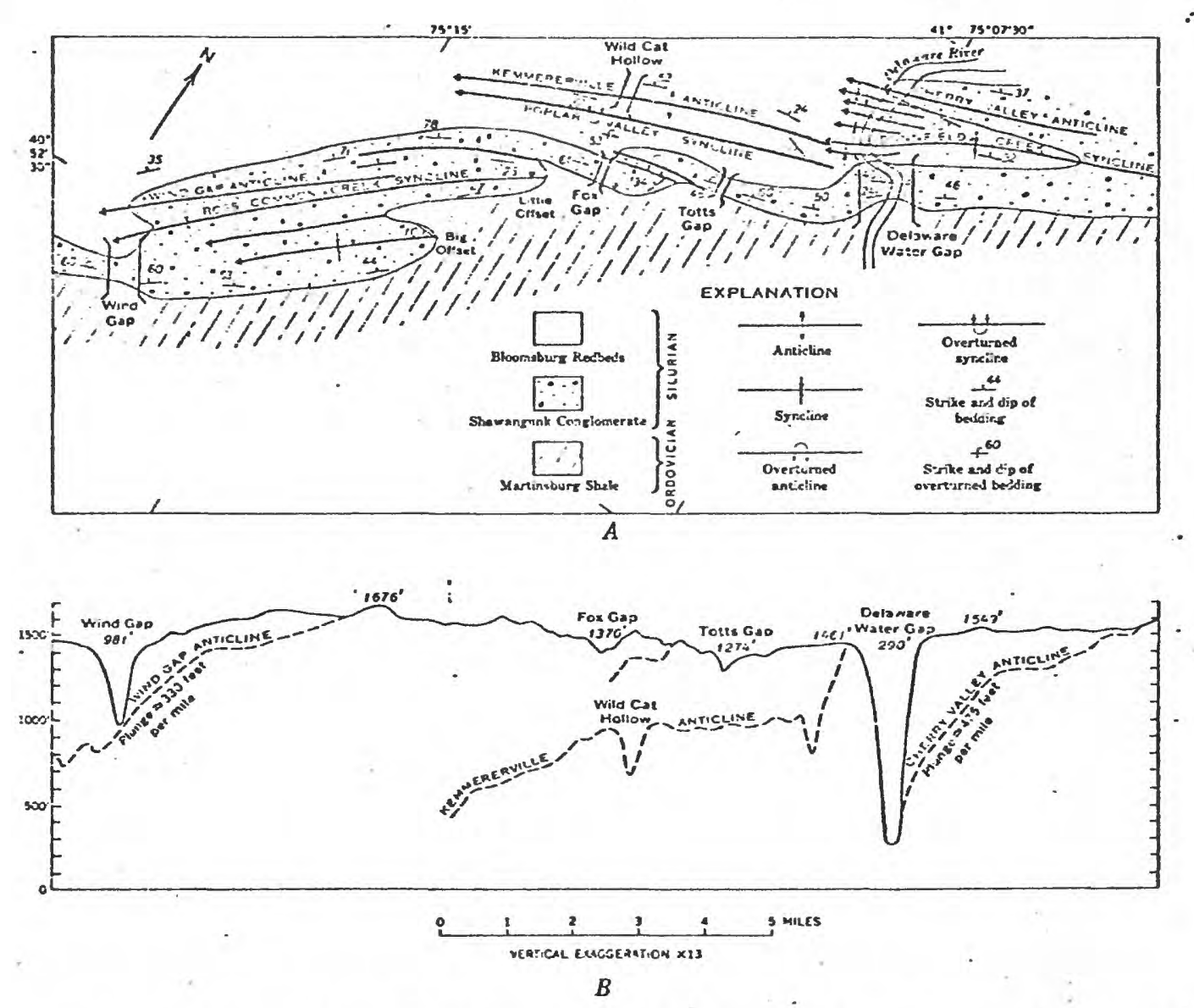

Figure 108. A, Geologic map of the Stroudsburg area, Pennsylvania and $\mathrm{New}$ Jersey. B, Projected longitudinal topographic profile, showing relation of geologic structure to location of gaps in Blue and Kittatinny Mountains. Profile viewed from the southeast. Dashed Iines indicate topography behind wain ridge and comespond approximately to crests of major anticlines. Several small folds north of Wind Gap, similar to those in Delaware Water Gap, are not shown; thelr extent is not well known because outcrops are poor. Topography from Wind Gap 15-minute quadrangle, $\mathrm{Pa} .-\mathrm{N} . J$., and Portland $7 \frac{1}{2}$-minute quadrangle, N.J.-Pa. 
142). Rogers (1858, v. 1, p. 283, v. 2, p. 896) noted that the ridge crest is offset 700 feet at the gap. He attributed the displacement to a transverse fault, as did Ashley (1935, p. 1406) and Willard (1938, p. 23). Chance (1882, p. 338), Johnson and others (1933, p. 26), Miller and others (1939, p. 144), and Strahler (1945, p. 58-59) belleved that the ridge is offset by a slight flexure. Thompson (1949, p. 56, 59) found many small faults which he suggested might be offshoots of a major transverse fault, and attempted to show that the gap is structurally controlled.

During the present study no cross fault could be found at Delaware Water Gap. The Shawangunk consists of three Members that match at river level and have contacts that are not displaced (pI I). The bedding dips $35^{\circ}$ to $45^{\circ}$ to the northrest on both sides of the river at the bottom of the gap. At the top of the ridge on the New Jersey side, at Mt. Tamany, the dip is about $50^{\circ}$, whereas on the Pennsylvania side the dip decreases upward toward Mt. Mins1, being less than $25^{\circ}$ at a place half-way up the mountain. Clearly, there 18 a small flexure at the gap; the beds on the New Jersey side dip more steeply than those in Pennsylvania, and the ridge crest in New Jersey lies about 700 feet northwest of the axis of the crest on the Pennsylvania side. The flexure can be seen by looking west from the New Jersey bank. Consideration of the structural geometry (fig. 109) reveals that there was an abrupt change in strike of the beds that formerly occupled the 


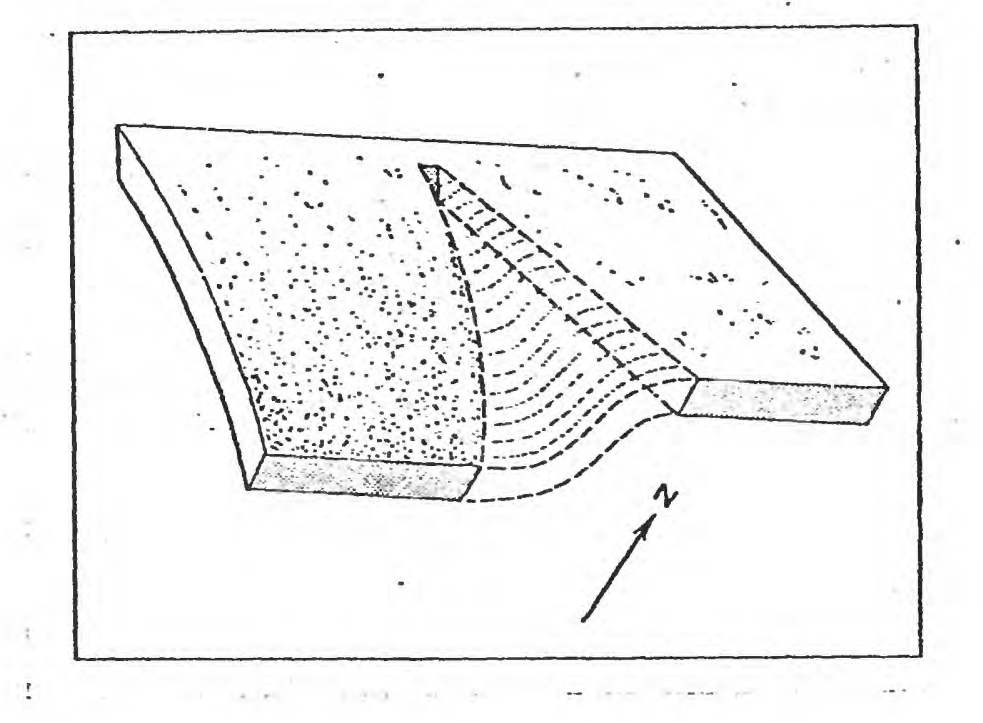

Figure 109. Diagram showing reconstructed flexure at Delaware Water Gap. Dashed Iines show form of bed before gap was cut. Presence of flexure accounts for the topographic offset of the ridge and suggests extensive fracturing of the Shawangunk Formation at the gap site in the flexure zone. 
gite of the gap. As a consequence the brittle Shawangunk must

have been weakened by extensive fracturing in the flexure zone. Structural control is therefore thought to have determined the location of the gep.

A series of folds in the Bloonsburg Red Beds along the course of the Delaware River north of the gap dies out to the southwest within a short distance ( 11 g. 108). Probably the rocks are more highly sheared here, and reststance to erosion is less than in the areas between gaps where simflar folds were not observed.

Perhaps equally important in controlling the location of Delaware Water Gap is the narrow width of outcrop of the Shawangunk Formation at the gap site than to the northeast where the formation is repeated in the southwest-plunging Cherry Valiey anticline. The river now flows on the Shawangunis where it crosses the anticline, but undoubtedly it flowed on the weaker Bloomsburg Red Beds earlier in its history before cutting down into the Shawangunk. This is an example of local superposition.

\section{Totts Gap}

The beds at Totts Gap are more strongly overturned than elsewhere along the ridge crest in the area of study, and It seems likely that the rocks here are weakened more than in adjacent areas. Moreover, the Shawangunk Formation has a narrow outcrop width at Totts Gap. Thompson (1949, p. 58) observed that between Totts Gap and Delaware Water Gap the ridge crest 18 lower where joints are more closely spaced than elsewhere, and that at Totts Gap, the 
lowest polnt along this stretch, the joints are most closely spaced.

Whether this reflects greater stress, or whether it is due to chance exposure of different beds in the Shatangunk that possess different structural characteristics, is difficult to deternine.

Fox Gap.

Fox Gap is located where two southwest-plunging folds die out over a short distance, much as they do at Delaware Water Gap. Also, the beds are strongly overturned, and the outcrop width is narrow.

\section{Wind Gap}

Geologic structures in Wind Gap duplicate those in the Delaware Water Gap area. Two major folds plunge out north of the gap. The Shawangunk Formation is not repeated to the northwest because the Wind Gap anticline plunges to the southwest. There is a $15^{\circ}$ difference in strike in beds in the ridge crest on either side of the gap, indicative of a plexure similar to that at Delaware Water Gap. In addition, several small folds in the Bloomsburg Red Beds are simflar to those in the Bloomsburg at Delaware Water Gap. These folds were not included in figure 108A becsuse outcrops are too few to permit tracing of their trends. Thinning of the outcrop width of the Shawangunk at the gap is evident on figure 108A. This is indicative of near-vertical dips which can be seen in cuts along the highway where it passes through the gep. 


\section{Gaps in Godfrey Ridge}

281

Godfrey Ridge lies about 2.5 miles north of Kittatinny Mountain and is supported by complexly folded Upper Silurian and Lower Devonfen Ifmestone, shale, sandstone, and conglomerate. Silty shale and sandstone of the Esopus Formation and Oriskany Group support the higher parts of the ridge (pl. III). Small folds are pumerous and die out rapidly. Sags in the ridge crest are numerous, but it is difficult to relste structural features to them. The two largest gaps in Godfrey Ridge, the gap of Brodbead Creek and North Water Gap, are located about 2.5 miles northnorthwest of Delaware Water Gap.

\section{Gap of Brodhead Creek}

Brodhead Creek cuts through Godfrey Ridge at an altitude of about 300 feet. No rock crops out in the creek bottom, but bedrock is exposed in the creek bed about 1 mile upstream. Therefore, bedrock cannot be far below creek level in the gap. Folding at the gap is so complex that Willard (1938, p. 23) belleved that the gap is the site of a north-south tear fault. Rather, there are four overturned folds in the southwestern part of the ridge near Brodhead Creek, two of which die out and are absent in the northeastern part. The abrupt dying out of folds Is well illustrated by sections $C-C^{\prime}$ and $D-D^{\prime}$ in plate III. Change In strike of the beds that formerly occupied the site of the gap is inferred, as it is at Delavare Water Gap. 
North Water Gap is located where Marshall Creek cuts through Godfrey Ridge, about half a mile northeast of the gap of Brodhead Creek. It is almost as deep as the latter, but bedrock is not exposed in the creek floor. Glaclal debris, whlch mey be of great thickness $^{1}$, is found along the course of the creek in the gap. Clearly, North Water Gap was much deeper in preglacial times.

The structure at North Water Gap is similar to the structure at the gap of Brodhead Creek. Two folds trending toward the gap Irom the northeast die out within the valley, and do not reappear in the ridge to the southwest (compare sections $B-B^{\prime}$ and $C-C^{\prime}$ in pl. III). The two gaps are therefore located at sites where folds plunge out abruptly, and Implication of structural control is clear. Moreover, because of near-vertical dips, the Oriskany and Esopus, which together make up the main ridge support, have a narrow outcrop widh.

\section{Stream Capture}

Structural relations in the Stroudsburg area are believed to have controlled not only the locations but also the history of the gaps. For example, Wind Gap was cut by a stream that was later captured north of Blue Mountain by tributaries of elther the Lehigh River to the west or the Delaware River to the east (Wright,

\footnotetext{
Bedrock was penetrated at a depth of 296 feet in a water well near the west bank of the Delaware River at an altitude of about 300 feet and approximately 2,000 feet southeast of the mouth of the gap, as reported by a local resident.
} 
1896; Ver Steeg, 1930; Willard, in Miller and others, 1939;

Mackin, 1941). Mackin showed that the drainage changes in the Wind Gap area were exceedingly complex and implied that evidence of the original captor of the Wind Gap River may be gone. Nevertheless, it seems likely that on the basis of structural considerations, the tributaries of the Delaware were more agressive than those of the Lehigh, and that a tributary of the Delaware captured the headwaters of Wind Gap River. Why was Wind Gap River, rather than the Delaware River tributary, beheaded? Kackin speculated that the present Delaware may have captured a stream that flowed through Culvers Gap in Kittatinny Mountain, 23 miles to the northeast, and greatly increased its own advantage, at that time, by this addition to its volume. Study of flgure $108 B$ suggests the following alternative explanation.

The Wind Gap River was captured just after it had cut down to an altitude of about 980 feet, the present altitude of the floor of the gap. At that level the stream had reached the resistant Shawangunk Formation in the Wind Gap anticline at about 980 feet, just northwest of the present gap, and its downcutting was retarded. The Delaware River, if it was at a simflar altitude at that time, as seems likely, was still cutting down through weaker Bloomsburg Red Beds in the Cherry Valley anticline where the top of the Shawangunk is several hundred feet lower. The lower altitude of the top of the Shawangunk at Delaware Water Gap is 
284

explained by the difference in plunge of the folds: the Cherry Valley anticline plunges about 475 feet per afle while the Wind Gap anticline plunges about 330 feet per mile. Iater, after the Delaware had ceptured the headwaters of Wind Gap River and cut through the Bloomsburg, it was superimposed on the Shatrangunk in the Cherry Valley anticline and slipped down the plunge of the fold in a curving course. The curve was accentuated when it migrated downstream and reached the steeply dipping Shawangunk quartzites and conglomerates just west of the gap. 


\section{APPENDIX}

Measured Sections

\section{Section 1}

Shawangunk Formation along Interstate Highway 80, Delaware Water Gap, Portland quadrangle, New Jersey. Beds generally dip moderately northwest but are interrupted by two small folds. Measurement begins within an estimated 3 feet of the covered contact between the Shawangunk Formation and liartinsburg Formation and ends at the contact betwreen the Shawangunk Formation and Bloomsburg Red Beds.

Shawangunk Formation:

\section{Thickness

(feet)

Tammany Member:

65. Quartzite and quartz-pebble conglomerate, medium-gray to medium-dark-grey, limonitic; quartz pebbles as much as 1.0 in. long; dark-gray argillite clasts as much as $2.0 \mathrm{in}$. long; beds as much as $12.0 \mathrm{ft}$. thick; crossbedded and planarbedded; uppermost few feet consists of reddishmedium-gray fine- to medium-grained quartzite and conglomeratic quartzite with angular pebbles as much as 1.0 in. in diarneter; top of unit forms dip slope in contact with red sandstone and siltstone of the Bloomsburg Formation; thickness of unit approximate; basal contact gradational... 241.0

64. Quartzite, medium-gray to medium-dark-gray, fine-grained, henatitic; crossbedded; massive and in beds as much as $5.0 \mathrm{ft}$. thick; some interbedded dark-gray argillite............. 125.0

63. Argillite, dark-gray; thins up-dip; basal contact abrupt................................ 3.2

62. Quartzite, medium-gray, fine-grained, limonitic; massive; basal contact gradational............ 4.8

61. Quartzite and argillite. Medium-gray to mediumdark-gray, fine-grained, quartzite interbedded with dark-gray argillite. Beds about 3.0 in. 
thick. Unit forms base of steep cliff at an elevation of $660 \mathrm{ft}$. Dark-gray argillite abruptly overlies dense massive quartzite at base.. 5.8

60. Quartzite, medium-gray to medium-dark-gray, fineto medium-grained, linonitic; massive; few interbeds of dark-gray arginitite; basal contact concealed..................................

59. Covered................................. 7.0

58. Quartzite, shaly siltstone, and silty shale. Medium-gray to medium-dark-gray, fine- to medium-grained, conglomeratic, limonitic, massive, crossbedded and planar-bedded quartzite in beds as much as $5 \mathrm{ft}$. thick interbedded with dark-gray lenticular argillite in beds as much as $2 \mathrm{ft}$. thick and argillite intraclasts as much as 5 in. long. Unit is more conglcweratic towards top. Basal contact abrupt.........................

57. Shaly siltstone, dark-gray, laminated; thins and pinches out $50 \mathrm{ft}$. up-dip; basal contact abrupt..

56. Quartzite, very fine to very coarse grained, mediumlight-gray to dark-gray, crossbedded and planarbedded, with quartz pebbles as much as 2.0 in. long. Scattered beds of dark-Eray siltstone and siltstone pebbles as much as 3 in. long. Basal contact abrupt and disconformable...............

55. Arginlite and quartzite. Dark-gray, quartzitic, arenaceous, limonitic, laminated shaly siltstone interbedded with medium-gray fine-grained quartzite. Unit thins up-dip as dark-gray argillite pinches out. Basal contact abrupt and disconformable...........................

54. Quartzite and silty shale. Medium-gray to medium-dark-gray, fine- to medium-grained, partly conglomeratic, massive, crossbedded and planarbedded quartzite with quartz pebbles as much as $\frac{1}{2}$ in. long and dark-gray argillite pebbles as much as 2 in. long interbedded with dark-gray argillite as much as 6 in. thick which thin up-dip. Pyrite cubes scattered throughout. Basal contact abrupt.................................. 
53. Shaly siltstone, dark-gray with pyrite cubes approximately $1 \mathrm{~mm}$. Iong, medium - to coarsegrained, massive, crossbedded and planar-bedded, conglomeratic quartzite bed 11 in. thick in middle of unit separated from an overlying fine- to medium-grained quartzite $?$ in. thick by a $2 \mathrm{in}$. siltstone bed. Unit thins up-dip.

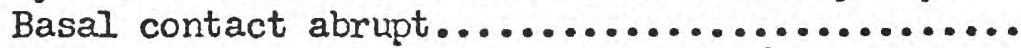

52. Quartzite and argillite. Medium-gray to mediumdark-gray, fine- to coarse-grained, conglomeratic (angular to rounded quartz pebbles as much as $\frac{1}{2}$ in. long and dark-Eray angular to discoidal argillite pebbles as much as 3 in.long), crossbedded and planar-bedded, massive quartzite with lenticular interbeds of dark-gray shaly siltstone as much as 4 in. thick. Unit more conglomeratic towards top. Basal contact

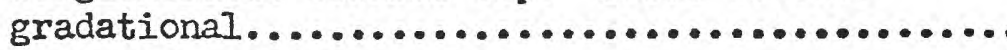

51. Quartzite, medium-gray to medium-dark-gray, fineto medium-grained, limonitic; crossbedded, planar-bedded, massive, in beds averaging 1.5 ft.; conglomeratic in uppermost foot; small pyrite cubes scattered throughout unit, especially in upper part; a few dark-gray burrow-mottled shaly siltstone and siltstone beds as much as 3 in. thick which pinch out within a few tens of feet are scattered throughout unit; basal contact abrupt................

Total thickness of Tammany Member...... 815.8

\section{Clinton Member:}

50. Quartzite, dark- to medium-gray, very fine to fine-grained, silty, argillaceous; with dark-gray discoidal silty shale clasts as much as 2 in. long; unevenly bedded; basal contact gradational.

49. Silty shale, dark-gray, alternating with mediumgray fine-grained limonitic quartzite in uneven beds less than 1 in. to 8 in. thick. Basal contact consists of dark-gray argillite lying

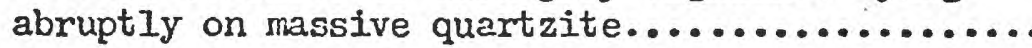

48. Quartzite, medium-gray, fine-grained, with scattered limonite flecks and dark-gray argillite 
pebbles averaging about $\frac{1}{2}$ in. In length; massive; vaguely parallel bedded to structureless; ripples with 3-in. wavelengths $1.5 \mathrm{ft}$. belor top; beds less than 1 to 15 in. thick; a few thin interbeds of dark-gray silty shale; basal contact irregular and gradational..............................

47. Quartzite, shaly siltstone, and silty shale. Darkgray, siliceous very unevenly bedded and lenticular shaly siltstone and silty shale beds as much as $5 \mathrm{ft}$. thick with thin lenses and beds of quartzite interbedded with mediur-gray to dark-gray, finegrained, massive, lenticular, partly crossbedded, locally very limonitic (Iimonite specks as much as $\frac{1}{4}$ in. in diameter), partly conglomeratic (intraclasts of dark-gray silty mudstone derived from underlying beds range in length from less than $\frac{1}{4}$ in. to as much as 2 in.). Quartzite in beds $1-18$ in. thick. Hany bedding planes contorted and show flow structures, channeling, some load casts, flaser bedding, and burrow mottling. One thin quartzite is boudinaged. Some beds rippled. Basal cont act consists of dark-gray silty mudstone in disconformable contact with massive quartzite. Some quartzite beds contain phosphatic intraclasts as much as 1 in. long. Base of unit has small scattered phosphatic intraclasts..................................

46. Quartzite, silty shale, and siltstone. Medium-darkgray, fine-grained, massive quartzite with limonite flecks in upper half underlain by medium-gray, fine-grained limonitic quartzite in uneven beds which are finely to moderately bedded (flaser bedding and burrowed where siltstone and silty shale are interbedded with finer grained quartzite), interbedded with dark-Eray muddy siltstone and silty mudstone in beds and lenses $\frac{1}{4}$ to 12 in. thick (mud flasers). Basal beds lenticular and very unevenly bedded and contain black phosphatic nodules. Basal $2 \mathrm{ft}$. consists of very irregularly int erbedded lenticular quartzite and flaser-bedded shale with abundant phosphatic nodules. Many of bases of quartaite lenses have load casts and sole narks. Phosphatic intraclasts weather white; they are rounded to angular and as much as 1.5 in. long. Many nodules are partly penetrated by quartz sand grains. Contact between units 45 and 46 is at road level at northwest end of stone retaining wall and is abrupt. 
Shawangunk Formation--Continued

45. Silty shale, shaly siltstone, and silty quartzite, medium- to dark-gray, fine-grained, partly limonitic; weathers pale-yellowish orange to light brom; laminated but appears massive in part; partly burrow mottled. Vertical burrows in upper $6 \mathrm{ft.}$ of unit; basal contact abrupt........

44. Quartzite, medium-dark-gray, fine-grained, partly limonitic; weathers light gray; massive; some beds contain dari-gray silty shale clasts as much as 1 in. long; bedding characteristic--crossbedded and planar-bedded. Basal contact abrupt.........

43. Shaly siltstone, silty shale, and quartzite. Dark-gray arenaceous shale and siltstone interbedded and interlensed with thin quartzite in upper half of unit. Ijight- to medium-gray, partly silty, laminated, crossbedded, and massive quartzite with a few thin interbeds of dark-gray mudstone in beds as much as 5 in. thick make up lower half of unit. A 3-in.-thick bed of finegrained convoluted quartzite $2.5 \mathrm{ft}$. below top of unit. Convolutions of laminated medium-light-gray to medium-gray very fine grained quartzite and medium-dark-gray siltstone. Basal contact abrupt.

42. Quartzite and silty shale. Medium-light-gray to medium-gray, fine-grained, massive, crossbedded quartzite containing dark-gray argillite fragments as much as 1 in. long. Quartzites are rippled and occur in beds $2-15$ in. thick and are unevenly interbedded and interlaminated with very dark gray shaly siltstone. Unit partly burrow mottled. Silty shale makes up 12 percent of unit. Basal contact consists of quartzite abruptly overlying dark-gray silty shale...............

41. Quartzite and shaly siltstone. Dark-gray, laminated shaly siltstone interbedded with dark-gray fine-crained to very fine grained silty crossbedded quartzite with clasts of siltstone as much as $\frac{1}{2}$ in. long. Unit partly burrow mottled at top with shale-filled burrows. Unit faulted at road level and repeated $50 \mathrm{ft}$. to northwest on northwest limb of small anticline. Basal contact abrupt.............................. 
Shawangunk Formation--Cont inued

290

Clinton Member--Continued

(feet)

40. Quartzite, medium-gray, fine-grained; massive; a few intercalations of dark-gray silty shale; crossbedded and planar-bedded, massive; basal contact abrupt............................

39. Quartaite, crossbedded and planar-bedded, lightolive-gray to medium-dark-gray, fine-grained, silty above basal foot and becoming very limonitic towards top of unit; basal foot consists of medium-gray quartzite resting disconformably on dark-gray shaly siltstone and silty shale of unit 38. Quartrite-filled, limonitic burrows in upper half (approximately $\frac{1}{4}$ in. in diameter and as much as 10 in. Iong) occur in silty fine-grained quartzite. Very conspicuous vertical burrows in upper $7 \mathrm{ft}$. Overiying units folded and faulted. Contact between units 39 and 40 is abrupt and is repeated $50 \mathrm{ft}$. to northwest................

38. Shaly siltstone and shale, dark-gray, laminated, alternating with light-olive-gray and medium-gray, fine-grained limonitic, crossbedded quartzite with dark-gray shale and clasts as much as 1 in. long. Beds from less than $\frac{1}{2}$ to $12 \mathrm{in}$. thick. Upper $3 \mathrm{ft}$. consists predominantly of laminated dark-gray argillite. Basal contact abrupt...............

37. Quartzite, medium-gray, fine-grained, limonitic, crossbedded, a few thin intercalations of darkgray silty shale comprise about 5 percent of unit; beds $4-20 \mathrm{in}$. thick; basal contact abrupt

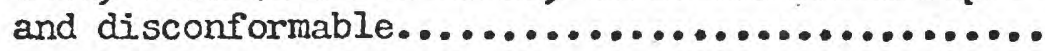

36. Silty shale and shaly siltstone, dark-gray, in uneven laminae and beds (beds as much as 3 in. thick) interbedded with light-olive-gray, finegrained, Iimonitic, thin-bedded quartzite which cormprises about 15 percent of unit. Wany sand-filled burrows parallel to bedding. Basal contact abrupt and disconformable.............

35. Quartzite, moderate-brown and medium-gray, finegrained, very limonitic with limonite concretions as much as 1 in. in diameter; unevenly bedded; bedding plane $1 \mathrm{ft}$. above base has ripple marks with amplitude of about $\frac{1}{2}$ in. and wavelength of about 3.5 in.; basal contact abrupt and disconformable................. 
34. Shaly siltstone and silty shale, dark-gray, with spherical limonitic concretions averaging about $I$ in. in diameter, unevenly interbedded with light-olive-gray to medium-gray fine-grained limonitic thin-bedded quartzite containing dark-gray argillite pebbles as much as 1 in. long. Upper $3 / 4 \mathrm{ft}$. is a light-gray fine-grained quartzite with dark-gray argillite pebbles as mach as $I$ in. long. Basal contact is abrupt and undulatory with many limonite concretions at or

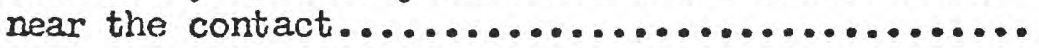

33. Silty shale, shaly siltstone, and quartzite.

Siltstone contains some clay clasts $\frac{1}{4}$ in. in diameter and is partly burrow mottled. Hediumgray to medium-Iight-gray, fine-grained limonitic crossbedded even-bedded quartzite makes up 50 percent of unit and is interbedded with dark-gray partly silty shale. A 3-in. thick, laterally discontinuous quartzite bed, $4 \mathrm{ft}$. above base of urit, contains thin (.1 to $1 \frac{1}{4}$ in.) branching argillite-filled burrows about 1 in. Iong. The finer grained quartzites are ripple topped.

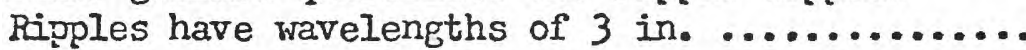

32. Quartzite, medium-gray, fine-grained, limonite flecks; massive, crossbedded, laminated. Basal contact abrupt and disconformable.............

31. Quartzite, medium-gray to medium-Iight-gray, fineto medium-grained, Iimonitic, massive, partly rippled, with minor shale clasts as much as 1 in. long, in beds 4 in. to $2.5 \mathrm{ft}$. thick; alternating with dark-gray silty shale, partly burrowed, in beds $I$ in. to $I \mathrm{ft}$. thick. Basal contact abrupt..

30. Siltstone, shaly, dark-gray, with fine-sand-filled burrows and fine-sand lenses; basal contact

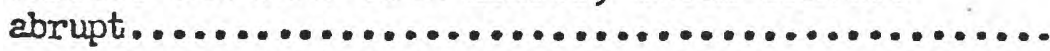

29. Quartzite, medium-gray, fine-grained, crossbedded, with $\frac{1}{2}$-in.-long clay galls alternating with dark-gray, limonitic silty shale and shaly siltstone in beds as much as 2 in. thick which cosprises less than 20 percent of unit. Basal contact abrupt and consists of a 2-ft. quartzite abruptly overlooking dark-gray argillite.........

28. Quartzite, medium-gray, fine-grained, crossbedded, unevenly bedded quartzite with rare clay galls as 
Shawangunk Formation--Continued

Clinton Nember--Continued

much as 1 in. long, comprising 70 percent of unit, alternating with dark-gray burrow-mottled silty shale and shaly siltstone. Basal contact

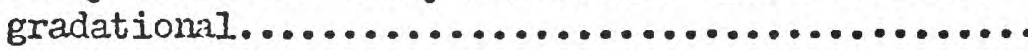

27. Quartzite, medium-gray, fine-to medium-grained, limonitic, crossbedded, massive; basal contact abrupt and disconformable.................. 5.8

26. Quartzite, medium-dark-gray, fine-grained, thinbedded to laminated, crossbedded, alternating with dark-gray silty shale and shaly siltstone. Beds $\frac{1}{2}$ in. to 3 in. thick. Basal contact abrupt......

25. Quartzite, muddy siltstone to silty mudstone, mediun-dari-gray, Iimonitic (Iimonite flecks about .I in. in diameter scattered throughout), massive, unevenly bedded; with scattered dark-gray argillite clasts as much as 2 in. 1ong, in beds 1-11 in. thick and comprising more than 90 percent of unit; and thin interbeds of dark-gray, partly burrow mottled, shaly siltstone. Graphite grains as much as .I in. long scattered throughout.............

24. Quartzite, and silty claystone, Iight-olive-gray, fine-grained, laminated, partly limonitic, evenly bedded, crossbedded quartzite alternating with dark-gray, silty, slabby, burrow-mottled, shale which comprises about 65 percent of unit. Beds $1-8$ in.

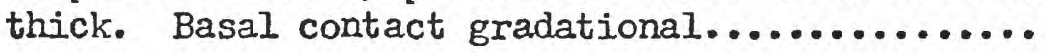

23. Quartzite and shaly siltstone. Medium-light-gray, medium- to fine-grained, limonitic, crossbedded quartzite with scattered dark-gray argillite clasis as much as $1 \mathrm{in}$. long in beds 1 to $19 \mathrm{in}$. thick and making up about 60 percent of unit. Quartzites interbedded with medium-dark-gray to dark-gray shaly siltstone with minor amounts of silty shale. Unit unevenly laminated to evenly bedded. Widely scattered irregular grains of graphite as much as .1 in. long. Some fine- to medium-grained sandfilled burrows $\frac{1}{4}$ in. in diameter. Basal contact covered.................................

22. Quartzite and shaly siltstone interbedded, in beds 1 in. to $3 \mathrm{ft}$. thick. Covered at road level but

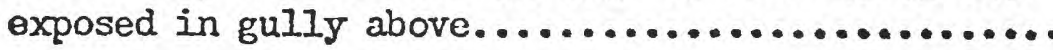


Shawangunk Formation--Continued

293

Thickness

Clinton Member--Continued

(feet)

21. Covered. Probably consists mostly of silt stone and

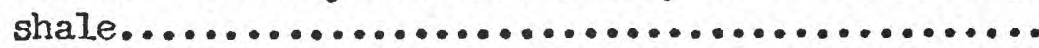

23.0

Total thickness of Clinton Member.

273.0

Minsi Nember:

20. Quartzite, light-to medium-gray, medium-grained to conglomeratic, with quartz pebbles as much as $\frac{1}{2}$ in. Iong, massive, crossbedded and planarbedded; uppermost bed is massive conglomerate about $2 \mathrm{ft}$. thick and is exposed in culvert on east side of road; 1 in.-thick medium-greenish-gray siltstone $5.3 \mathrm{ft}$. above base. Basal contact gradational....

19. Siltstone, shaly, dark-gray, finely laminated, interbedded with medium-dark-gray, conglomeratic, silty, fine-grained quartzite; basal contact abrupt................................

18. Quartzite, medium-gray, fine- to medium-grained, limonitic; scattered angular quartz and chert pebbles as much as $\frac{1}{2}$ in. long; crossbedded and planar-bedded; massive; a few interbedded darkgray shaly siltstone beds 1 in. thick or less; basal contact abmupt and disconformable...........

17. Siltstone and silty shale, dark-gray, comprise about 65 percent of unit, interbedied with medium-gray, medium-grained, crossbedded quartzite and quartzand chert-pebble conglomerate. Basal contact abrupt.

16. Quartzite, light-olive-gray to light-gray, mediumgrained, partly conglomeratic (angular to subrounded quartz pebbles as much as $\frac{1}{2} \mathrm{in}$. long and shale clasts as much as 1 in. long), local ripples; lenticular, intervedded with dark-gray, laminated shaly siltstone in beds 1 in. to $8 \mathrm{in.}$ thick and comprising about 10 percent of unit. Basal contact abrupt.... 37.8

15. Siltstone, shaly, dark-gray, interbedded with light-olive-gray and medium-dark-gray; mediumgrained, Iimonitic, crossbedded quartzite. Unit from top to bottom consists of: 
Shawangunk Formation--Continued

Minsi Member--Continued

$\frac{\text { Thickness }}{\text { (feet) }}$

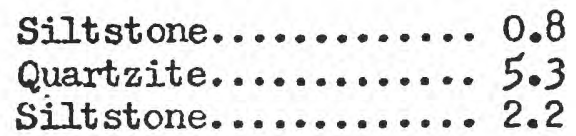

Basal contact abrupt and disconformable.........

8.3

14. Conglomerate and quartzite. Light-olive-gray to medium-dark-gray conglomerate with clasts as much as $3 / 4$ in. long composed predominantly of quartz but with scattered dark-gray shale pebbles as much as $1 \mathrm{in.}$ long alternating medium-gray to dark-gray, medium - to coarse-grained quartzite. Unit massively bedded and crossbedded. Basal $\frac{l}{2} \mathrm{ft}$. is a conglonerate bed which locally grades into underlying light-gray quartzite...............

13. Quartzite, light-gray to light-olive-gray, fine- to medium-grained, planar-bedded; weathers to a lighter color than units above and below; fer thin lenses of darker gray quartzite; basal contact gradational.................................

12. Quartzite, conglomeratic quartzite, and conglomerate, light-olive-gray and medium-dark-gray to lightgray, predominantly medium grained; massively bedded; crossbedded and finely laminated; a few intercalations of dark-gray shaldy siltstone totaling no more than 3 in.; some siltstone pebbles as much as 4 in. long; basal contact abrupt.......

11. Siltstone, shaly, arenaceous, dark-gray, siliceous, laminated, alternating with light-olive-gray and moderate-dark-gray, medium- to coarse-grained, partially conglomeratic (pebbles no more than $\frac{1}{4}$ in. long) quartzite. Basal contact abrupt and disconformable.

10. Quartzite and conglomerate, light-olive-gray and medium-dark-gray, fine- to meoiium-grained; conglomerate comprises about 10 percent of unit; massively bedded; crossbedded; a few thin intercalations and channel fillings of dark-gray siltstone comprising about 4 percent of unit; basal contact

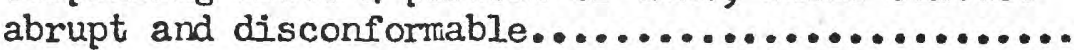

9. Conglomerate and quartzite; Iight-olive-gray to medium-dark-gray, crossbedded and planar-bedded, quartzitic conglomerate with clasts as much as 
3/4 in. in diameter and scattered silty shale clasts as much as 4 in. long interbedded with dark-gray, fine-grained, argillaceous quartzite and siltstone. At road level are 4 dark-gray siltstone beds which range up to $1 \mathrm{ft}$. in thickness; these beds thicken and thin laterally. Conglomerates and quartzites between the siltstones are lenticular. This unit is persistant for at least $100 \mathrm{ft}$. up-dip. Muclcracks found up-dip at edge of cliff, approximately $60 \mathrm{ft}$. above road level. Basal contact abrupt and disconformable................

8. Quartzite, alternating medium-gray and light-olivegray to light-gray, fine-to medium-grained; planar-bedded beds 2 in. to $3 \mathrm{ft}$. thick; basal

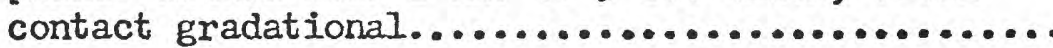

7. Conglomerate and conglomeratic quartzite, lightolive-gray to medium-dark-gray; crossbedded and planar-bedded; clasts as much as 1 in. Iong in a matrix of medium-grained quartzite, comprise basal $2.5 \mathrm{ft}$. and grades up into medium-gray, mediumgrained laminated to fine-bedded quartzite; basal contact abrupt.............................

6. Quartzite, light-olive-gray, fine- to medium-grained; a few scattered pebbles about $\frac{1}{4}$ in. long; basal few feet contains lenses of medium-dark-gray medium- to coarse-grained quartzite; upper half of unit crossbedded; basal half of unit planar bedded; basal contact abrupt...............................

5. Quartzite, light-olive-gray, medium-gray to mediumdark-gray, predominantly medium grained, partly coarse grained; a few scattered angular pebbles as much as $\frac{1}{2}$ in. long; crossbedded. Basal cont act abrupt.

4. Conglomerate and quartzite, light-olive-gray and light-gray to medium-gray, mediun- to coarse-grained, limonitic, partly crossbedded, lenticular. Pebbles of angular quartz and dark-gray chert as much as 2 in. in diameter and averaging $\frac{1}{2}$ in. in diameter. Base of many conflomerate beds disconformable with channels about $\frac{1}{2} \mathrm{ft}$. deep. There are 6 pronounced conformable contacts within this unit at road levels. Conglomerate grades up into or is int erbedded with 
Shawangunk Formation--Continued

Minsi Member--Continued

finer quartzite. Conglomerate beds 1 in. to

$1 \mathrm{ft}$. thick. A few light-olive-gray shaly siltstone lenses averaging about $2 \mathrm{in}$. in length scattered throughout unit. Basal contact abmupt..

3. Quartzite and conglomeratic quartzite, angular pebbles of milky quartz predominate with scattered dark-gray chert and argillite pebbles as much as 1 in. long in a matrix of medium-dark-gray, medium- to coarse-grained quartzite; conglcmeratic and feldspathic at base becoming finer grained toward top of unit; unevenly bedded; conglomeratic beds lenticular; basal contact gradational........

2. Quartzite, Iight-olive-gray and meoium-light-gray to mediun-gray, fine-grained to conglomeratic; crossbedded to planar-bedded partially limonitic; angular to rounded quartz pebbles with a few dark-gray to grayish-black chert pebbles approximat $\in$ ly $\frac{1}{2}$ in. long; irregular bedded and crossbedded; conglomeratic, medium- to coarsegrained, and fine-grained quartzite beds $I$ in. to $1 \mathrm{ft}$. thick alternate; thin lenses of light-olivegray shaly siltstone not more than 1 in. thick and as much as $10 \mathrm{ft}$. Iong; Iimonitic concretions, $1-1 \frac{1}{2}$ in. in diameter are scattered throughout but occur in zones along bedding plames; basal contact covered................................. 18.4

1. Covered; contact between Shawangunk and Martinsburg Formations covered by colluvium; covered interval about 2 ft. thick......................... 2.0

Approximate thickness of Minsi Member....... 302.6

Total thickness of Shawangunk Formation 1391.2 
Upper part of the Tammany lember of the Shawangunk Formation and lower part of the Bloomsburg Red Beds, Delaware Water Gap,

- Stroudsburg quadrangle, Pennsylvania. Traverse begins 100 feet east of the southern contact between the Shawangunk Formation and Bloomsburg Red Beds, extends 2,380 feet northwest along U.S. Highway $611 A$, rises up the cliff face, and then to the St. Marks Church in the village of Delaware Water Gap. LUnits 101 to 119 and 123 are tongues of the Shawangunk Formation within the Bloomsburg Red Beds. For convenience, their thickness, totaling 129.9 feet, is included within the measurements for the Bloomsburg. 7

Bloomsburg Red Beds (part):

Thickness

123. Siltstone, greenish-gray; traverse down dip slope (feet) ends $200 \mathrm{ft}$. in a direction $\mathrm{N} .60^{\circ} \mathrm{W}$. where road near St. Marks Church is intersected; to the northuest of this point the beds rise in an

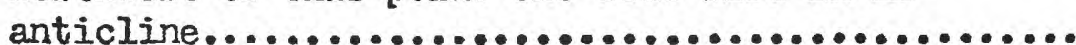

122. Siltstone, shaly greenish-gray with pale- to grayish-red-purple mottles; upper 3 in. grayishred-purple siltstone; upper contact concealed, traverse continues to top of hill then doim dip slope of unit 122 for $625 \mathrm{ft}$. in a N. $60^{\circ} \mathrm{W}$. direction................................

121. Sandstone, shaly, alternating greenish-gray and

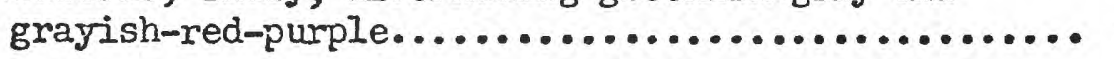

120. Siltstone, arenaceous grayish-red-purole.......... 10.1

119. Covered................................ 10.0

118. Siltstone, dark-gray, interbedded with medium-gray, very fine grained, argillaceous sandstone; unit exposed in ledges in slope above bluff; top of unit 118 forms dip slope on northwest side of hill; traverse continues $N .50^{\circ}$ W. down dip slope of unit

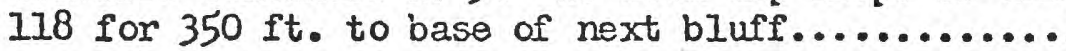

177. Covered.............................. 5.0

116. Quartzite, dark-gray, very fine grained, limonitic; and dark-gray siltstone; unit forms top of bluff...

115. Sandstone, medium-dark-gray, very fine grained,

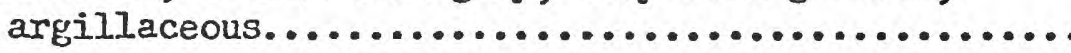

114. Siltstone, dark-gray...................... 
Bloomsburg Red Beds (part)--Continued

113. Sandstone, medium-rlark-gray, very fine grained; basal contact abrupt and irregular.............. 4.0

112. Siltstone, dark-gray; basal contact gradational...... 1.0

21]. Sandstone, medium-dark-gray; very fine grained; basa] contact gradational

110. Siltstone, dark-gray...................... 3.6

109. Sandstone, dark-gray, very fine grained, siliceous... 2.3

108. Siltstone, dark-gray..................... 5.1

107. Siltstone, dark-rray, interbedded with medium-gray and olive-greenish-gray, very fine to medium-grained sandstone. Unit evenly bedded with beds $2-15$ in. thick...................................

106. Partially exposed; a few ledges of medium-gray, fine-grained, argillaceous, limonitic sandstone....

105. Sandstone, medium-gray, and dark-gray siltstone; traverse continues north along Appalachian Trail for $540 \mathrm{ft}$. to a subsidiary trail which leads N. $50^{\circ} \mathrm{W}$. away from main trail. Top of unit 104 is $50 \mathrm{ft}$. up subsidiary trail. Top of unit 105 is $200 \mathrm{ft}$. along subsidiary trail from top of unit 104. Traverse continues up knoll $\mathrm{N} .70^{\circ} \mathrm{W}$. from top of unit 105 and crosses dirt road............... 20.0

104. Sandstone, medium-gray, medium-grained, limonitic..... 2.7

103. Sandstone, greenish-gray, medium-grained, Iimonitic at base and grades up.into argillaceous sanàstone... 7.0

102. Sandstone, greenish-gray, fine-grained........... 5.4

101. Sandstone, greenish-gray, fine-grained............ 5.0

100. Sandstone, greenish-gray, argillaceous, grades up into grayish-red-purple silty shale............... 4.7

99. Sandstone, greenish-gray, fine-grained............ 2.4

98. Siltstone, grayish-purple, arenaceous............ 2.7

97. Quartzite, gray, fine-grained................. 1.3

96. Shale, grayish-purple........................ 0.3 
Bloomsburg Red Beds (part)--Continued

95. Sandstone, greenish-gray, fine-grained............. 1.9

94. Quartzite, greenish-gray, fine-grained............. 1.0

93. Siltstone, greenish-gray, arenaceous............... 0.5

92. Quartzite, gray, fine-grained.................. 0.8

91. Quartzite, greenish-gray, fine-grained, with pale-redpurple to grayish-red-purple mottles; interbedded with greenish-gray arenaceous silty shale with pale-redpurple to grayish-red-purple mottlies.............. 5.0

90. Shale, silty, pale-red-purple to grayish-red-purple.... 1.3

89. Sandstone, greenish-gray, fine-grained............. 0.7

88. Shale, silty, pale-red-purple to grayish-red-purple.... 0.9

87. Quartzite, gray, medium-grained, limonitic............ 4.3

86. Sandstone, greenish-gray, medium-grained........... 1.0

85. Quartzite, gray, fine-grained, limonitic............ 3.3

84. Shale, silty, pale-red-purple to grayish-red-purple.... 3.3

83. Quartzite, gray, fine- to medium-grained, grades up into greenish-gray shaly siltstone in upper half of unit. Basal contact gradational................. 4.7

82. Siltstone to medium-grained sandstone, pale-red-purple to grayish-red-purple..........................

81. Sandstone, medium-gray, medium-grained, limonitic...... 3.1

80. Siltstone and fine-grained sandstone, pale-red-purple

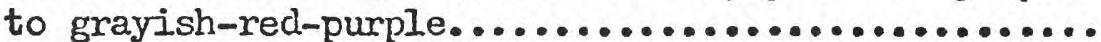

79. Sandstone, medium-gray and greenish-gray, fine- to medium-grained.

78. Siltstone, shaly pale-red-purple to grayish-red-purple. 3.5

77. Sandstone, medium-gray and greenish-gray, mediumgrained, limonitic...........................

76. Siltstone, arenaceous and fine-grained silty sandstone, pale-red-purple to grayish-red-purple; basal contact gradational.................................. 
75. Sandstone, medium-gray and greenish-gray, medium-

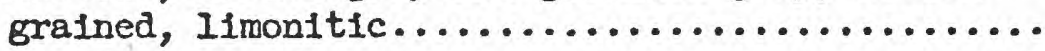

74. Shaly siltstone and interbedied fine-grained sandstone, pale-red-purple to grayish-red-purple.... 4.0

73. Sandstone, medium-gray, medium-grained, IImonitic; grades up into pale-red-purple to grayish-red-

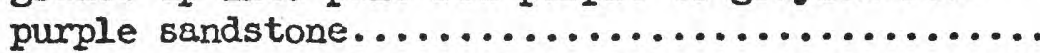

72. Quartzite, sandstone, and siltstone. Basal foot is medium-gray, medium-grained quartzite which grades up into pale-red-purple to grayish-red-purple, finegrained sandstone and shaly siltstone......... 7.2

71. Shaly siltstone and interbedded fine-grained sandstone, pale-red-purple to gray1sh-red-purple.....

70. Quartzite, medium-gray, medium-grained, limonitic.. 2.0

69. Shaly siltstone and Interbedded fine-grained sandstone, pale-red-purple to grayish-red-purple.... 12.0

68. Covered............................... 2.0

67. Quartzite, medium-gray to greenish-gray, conglomeratic (pebbles as much as $\frac{\bar{t}}{2}$ in. In diameter); crossbedded; channeled into unit below; a few thin streaks of greenish-gray silty shale; basal contact abrupt. Untt traced to north for $550 \mathrm{ft}$. through series of folds and then measurement continues up cliff....

66. Quartzite, pale-red-purple to grayish-red-purple, medium- to coarse-grained conglomeratic, crossbedded; grades up into interbedded pale-redpurple to gray1sh-red-purple fine- to mediumgrained quartzite and arenaceous siltstone; many red beds grade laterally into greenish-gray beds northward; basal contact gredational.......... 13.8

65. Quartzite, medium-gray to greenish-gray, mediumto coarse-grained, conglomeratic; a few quartz pebbles as much as $\frac{l}{2}$ in. long; crossbedded...... 5.5

64. Quartzite, grayish-red-purple to pale-red-purple, very fine grained to medium-grained, argillaceous, crossbedded. Middle of unit contains interbeds of greenish-gray, medius-grained quartzite.........

63. Quartzite, medium-gray to greenish-gray, fine- to medium-grained, conglomeratic (pebbles as much as $\frac{1}{4}$ in. Iong); crossbedded; channeled at base; grades 
Bloomsburg Red Beds (part)--Continued

301

Thickness

laterally into pale-red-purple to grayish-red-

(feet) purple beds of same lithic type interbedded with greenish-gray, fine-grained, limonitic, crossbedded

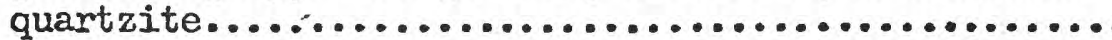

62. Quartzite, medium-gray, medium-grained, conglomeratic, Iimonitic, crossbedded; grades up into fine-grained quartzite which in turn becomes greenish-gray and

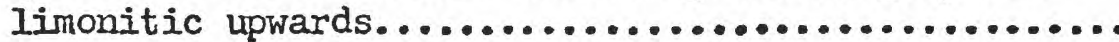

61. Siltstone, shaly, greenish-gray, limonitic; basal

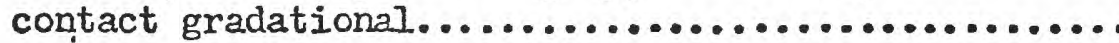

60. Quartzite, grayish-red-purple to pale-red-purple, and greenish-gray to mediun-gray fine-grained, interbedded with pale-red-purple to grayish-red-purple, mediumgrained partially limonitic and conglomeratic quartzite and arenaceous siltstone.................

59. Siltstone, shaly, grayish-red-purple to pale-red-purple, poorly exposed, grades up into grayish-red-purple and pale-red-purple, very fine grained, argillaceous quartzite which in turn grades up into medium-gray,

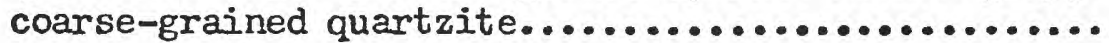

58. Quartzite, greenish-gray, fine-grained, limonitic; grades up into medium-gray, coarse-grained quartzite.

57. Sandstone, greenish-gray, argillaceous............. 0.8

56. Quartzite, greenish-gray, fine- to medium-grained; grades up into grayish-red-purple, fine-grained quartzite................................

55. Quartzite, medium-gray to greenish-gray, medium- to coarse-grained; massive; chameled into beds below...

54. Quartzite, grayish-red-purple, partially limonitic, crossbedded, with interbeds of pale-red-purple arenaceous shaly siltstone and scattered interbeds of greenish-gray sandstone and siltstone.

53. Quartzite, grayish-red-purple and greenish-gray, fine-grained, channeled into beds below, grades laterally and vertically into pale-red-purple to grayish-red-purple arenaceous siltstone.......... 14.5

52. Quartzite, medium-gray, fine-grained, limonitic, massive, grades up into greenish-eray quartzite and pale-red-purple to grayish-red-purple, crossiedded, 


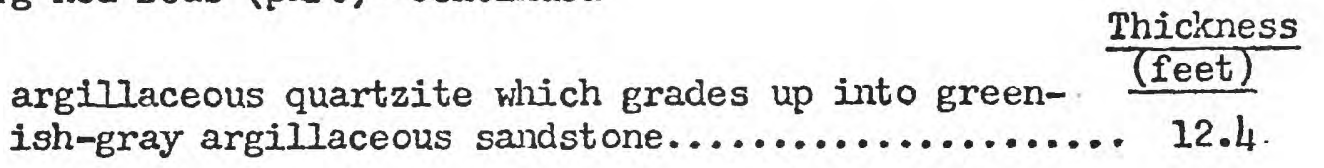

51. Siltstone, grayish-red-purple, quartzitic.......... 4.5

50. Quartzite, grayish-red-purple, fine-grained......... 2.8

49. Quartzite, grayish-red-purple, silty, and grayish-redpurple quartzitic siltstone.................... 3.4

48. Quartzite, medium-gray, fine-grained, hematitic...... 1.2

47. Quartzite, pale-red-purple, pale-red to grayish-red, silty, limonitic; and quartzitic and shaly siltstone........ 25.0

46. Quartzite, medium-gray and greenish-gray, fine-grained, limonitic................................... 0.3

45. Siltstone, pale-red-purple to grayish-red-purple,

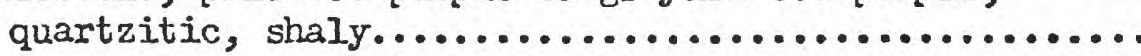

44. Quartzite, fine-grained, medium-gray grading up into grayish-red-purple, very fine grained quartzite...... 0.6

43. Quartzite, medium-gray and greenisi-gray, fine-to coarse-grained, partially conglomeratic; scattered $I$ in.-thick mudstone intercalations............... 3.1

42. Siltstone, greenish-gray...................... 0.4

41. Quartzite, medium-dark-gray, fine-grained, limonitic.... 1.7

40. Shale, silty light-green........................ 0.2

39. Quartzite, medium-gray, fine-grained, limonitic........ 2.8

38. Quartzite, grayish-red-purple, fine- to medium-grained, limonitic, crossibedded; and grayish-red-purple to pale-red-purple quartzitic siltstone............... 9.9

37. Shale, silty pale-red-purple to grayish-red-purple..... 0.4

36. Quartzite, graylsh-red-purple, fine-grained, hematitic.. 0.5

35. Shale, silty, grayish-red-purple to greenish-gray...... 0.2

34. Quartzite, grayish-red-purple, fine-to coarse-grained, congloneratic; crossbedded........................ 
33. Siltstone, quartzitic, pale-red-purple to grayishThickmess red-purple and fine-grained, silty quartzite.

32. Quartzite, grayish-red-purple to pale-red-purple, medium-grained to coarse-grained, limonitic; crossbedded.........

31. Quartzite, grayish-red-purple, fine- to coarse-grained, conglomeraitic; crossbedded.................... 2.2

30. Siltstone, greenish-gray, interbedded with medium-gray fine-grained quartzite........................

29. Quartzite, medium-gray and gravish-red-purple, finegrained to coarse-grained, Iimonitic.............. 4.0

28. Siltstone, shaly, grayish-red-purple to pale-red-purple; interbedded with grayish-red-purple, fine-grained, silty quartzite...............................

27. Conglomerate, grayish-red-purple; angular to subrounded milky quartz and jasper pebbles as much as $\frac{1}{2} i n$. long........................................

26. Conglomerate, quarizite and siltstone. Conglomerate with angular to subrounded milky quartz and pale-redpurple jasper pebbles comprise basal 2 in.; grades up into grayish-red-purple, medium-grained conglomeratic quartzite, shaly siltstone. Basal contact abrupt and disconformable................................

25. Quartzite, silty, grayish-red-purple, fine- to mediumgrained, partly conglomeratic (angular to subrounded pebbles as much as $\frac{1}{2}$ in. lonf), partially crossbedded; interbedded with grayish-red-purple silt st one........ 15.1

24. Quartzite, grayish-red-purple, fine-grained, grades up into pale-red-purple to grayish-red-purple silty quartzite...................................

23. Quartzite, grayish-red-purple, fine-to mediun-grained, partially conglomeratic (subrounded quartz pebbles as much as 0.4 in. long); crossbedded; basal contact abrupt and disconformable.

22. Quartzite, grayish-red-purple to pale-red-purple, fineto medium-grained, limonitic; interbedded with palered-purple to grayish-red-purple quartzitic siltstone. 11.1

21. Siltstone, grayish-red-purple, quartzitic............ 3.8 
Bloomsburg Red Beds (part)--Continued

304

Thickness

(feet)

20. Quartzite, grayish-red-purple, conglomeratic with quartz and jasper pebbles as much as $\frac{1}{4}$ in. long, crossbedded; basal contact abrupt and disconformable..................................

19. Quartzite, grayish-red-purple, silty............ 2.6

18. Quartzite, medium-gray grading upward to greenishgray, limonitic; crossbedded..................

17. Quartzite, pale-red-purple to grayish-red-purple, fine- to coarse-grained, medium gray near base, partly limonitic, crossbedded; interbedded with pale-red-purple to grayish-red-purple siltstone and

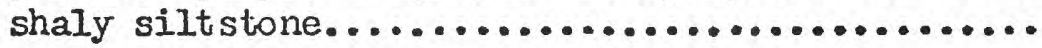

16. Quartzite, silty, grayish-red-purple, massive;

interbedded with grayish-red-purple quartzitic

siltstone..............................

15. Siltstone, light-brownish-gray to pale-red-purple and grayish-red-purple, quartzitic, partly shaly; cleavage limited to argillaceous beds; basal contact with Shawangunk Formation gradational within a I-ft. interval and consists of greenish-gray silty quartzite (Shawangunk Formation) in contact with pale-red-purple to grayish-red-purple quartzitic siltstone (Bloomsburg Red Beds); color contact oblique to bedding..........................

Incomplete thickness of Bloomsburg Red Beds... 700.8

Shawangunk Formation (part):

Tammany Member (part):

14. Siltstone, greenish-gray, shaly, grades up into medium-gray, fine-grained, silty quartzite which in turn grades up into medium-gray, fine-grained

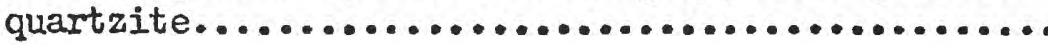

13. Quartzite, medium-dark-gray, fine-grained........ 3.4

12. Siltstone, greenish-gray, shaly............... 1.0

11. Quartzite, medium-dark-gray, fine- to medium-grained. 3.0

10. Shale, silty, medium-gray to light-olive-gray....... 1.1 
Shawangunk Formation (part)--Continued

Tammany Member (part)--Continued

(feet)

9. Quartzite, medium-dark-gray, fine-grained, partly conglomeratic, micaceous.

8. Siltstone, greenish-gray, quartzitic, limonitic...... 1.3

7. Quartzite, medium- to medium-dark-gray, fine-grained, partly henatitic and silty; beds as much as $7 \mathrm{ft}$.

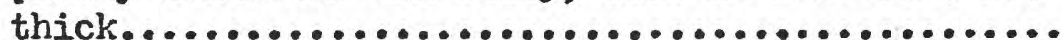

6. Shale, medium-dark-gray.................... 0.6

5. Quartzite, medium-gray to medium-dark-gray to greenish-gray, fine- to medium-grained partly silty, limonitic, crossbedded; beds $3-4$ in. thick........ 30.5

4. Quartzite, fine-grained, Iight-olive-gray to mediumgray, silty; unit thickens up-dip.............. 2.0

3. Quartzite, medium-gray to light-olive-gray, fine- to medium-grained, partly silty, hematitic; beds as much as $3 \mathrm{ft}$. thick.

2. Siltstone, medium-gray to light-olive-gray, shaly and quartzitic................................

1. Quartzite, medium-gray to medium-dark-gray, fine- to medium-grained, massive; beds as much as $3 \mathrm{ft}$. thick; basal contact concealed.

Incomplete thickness of Tammany Hember......... 82.8

Incomplete thickness of Shawangunk Formation.... $\underline{\underline{82.8}}$

\section{Section 3}

Coeymans and Rondout Formations, a7ong southeast bank of Brodhead Creek, approximately 1,000 feet above dam and 3,000 feet southwest of Minisink Hills, Stroudsburg quadrangle, Pennsylvania. Beds vertical.

Coeymans Formation (part):

Stormville Member (thickness not measured)

Shawnee Island Member:

8. Limestone, arenaceous and argillaceous, finely to moderately crystalline, medium-dark-gray to medium-gray; weathers medium to light-medium gray; irregularly bedded; about 5-10 percent nodular 
Coeymans Formation (part)--Continued

dark-gray chert; a continuous chert bed $\frac{1}{2}-1 \mathrm{ft}$. thick $4 \mathrm{ft}$. below top; thin sand lenses occur as low as $5 \mathrm{ft}$. below top of unit; crinoid columnals and Gypidula coeymanensis abundant; upper contact disconformable; lower contact sharp and placed at first appearance of dark-gray chert..............

7. Limestone, arenaceous and argillaceous, finely to moderately crystalline, medium-dark-gray to mediumgray; weathers light-medium gray, limonitic; irregularly bedded; fossils abundant and include Gypidula coeysnanensis, Leptaena rhomboidalis, stropheodontid brachiopods, fenestellid and trepostome bryozoans, tabulate and rugose corals; lower contact transitional.................. 18.5

Total thickness of Shawnee Island Member....... 35.0

Peters Valley Member:

6. Limestone, very arenaceous and argillaceous with scattered quartz pebbles up to $\frac{1}{4}$ in. in diameter, medium-gray, finely to moderately crystalline; weathers light-medium gray; occurs in beds $1 \frac{1}{2} \mathrm{ft}$. thick; partly crossbedded; abundantly fossiliferous; Gypidula coeymanensis and favositids especially abundant; lower contact transitional............ 5.0

Total thickness Peters Valley lember......... 5.0

Depue Limestone Member:

5. Limestone, slightly arenaceous, medium-to dark-gray; weathers medium gray; limonitic; very thin argillaceous limestone partings produce a ribbony character; basal 1-2 ft. of unit consists of crossbedded sandy limestone; stropheodontid brachiopods and ostracodes abundant; lower contact abrupt.. 18.0

Total thickness Depue Limestone Member........ 18.0

Incomplete thickness Coeymans Formation...... 58.0 
Rondout Formation:

Mashipacong Member:

4. Calcareous shale and argillaceous limestone; mediumgray; weathers medium-yellow gray; laminated and mudcracked; unfossiliferous; lorer contact abrupt..

Total thickness Hashipacong Member............

Whiteport Member:

3. Dolomite, very finely crystalline, medium-gray; weathers bromish orange; laminated and deeply mudcracked; laminae are alternations of pure dolomite and slightly argillaceous dolomite with argillite weathering a lighter color; dark-gray calcareous shale partings between mudcrack polygons; unit unfossiliferous; lover contact abrupt..........

Total thickness Whiteport Hember........... 9..

Duttonville Member:

2. Limestone, slightly argillaceous, finely crystalline; medium-gray; weathers medium gray; beds 1 ft. thick; ribbony; ribbons due to alternations of purer limestone and more argillaceous limestone. Basal foot consists of a biostrome of fragmented horn and colonial corals and brachiopods; 1 ft. 3 in. above base are numerous smooth-shelled ostracodes covering all bedding planes to top of unit; the more argillaceous ribbons contain fever numbers of ostracodes; lower contact abrupt, placed at base of biostrome......................................

1. Iimestone, very argillaceous, very finely crystalline, medium-gray; weathers yellowish gray; weathers into thin layers from 1 in. to $\frac{1}{4} \mathrm{in}$. thick; unit laminated and mudcracked; mudcracks begin 1 ft. above contact with Decker; mudcracks $1 \frac{1}{2}$ to 4 in. vide and well defined; unit unfossiliferous; lover contact abrupt. $\quad 7.0$

Total thickness Duttonville Hember........... 11.5

Total thickness Rondout Formation........... 28.5 Decker Formation (thickness not measured) 
Stornville and Shawnee Island Members of the Coeymans Formation in a series of ledges on hillside above house on south side of Cherry Valley Road, 1,000 feet east of intersection with Route 191,

Stroudsburg quadrangle, Pennsylvania. Beds dip gently northeast.

Coeymans Formation (in part):

Thickness

Stormville Member:

(feet)

7. Sandstone, calcareous, fine- to medium-grained, light- to medium-gray; and finely to coarsely. crystalline arenaceous limestone; upper contact concealed, but beds believed to be at top of member;

lower contact concealed............................

6. Covered...................................... 2.0

5. Sandstone, pebbly and coarse-grained, quartz-pebble conglomerate; sandier lenses crossbedded; medium- to light gray; weathers tan gray; forms ledge; 7-8 ft. above base is conglomerate (quartz pebbles subrounded to well rounded and up to 1 in. long) which is immediately overlain by a fossil hash of brachiopods (Gypidula coeymanensis) and disarticulated crinoid columnals up to $1 / 8$ in. in diameter; upper $\frac{1}{2} \mathrm{ft}$. is a coarse-grained quartz-pebble conglomerate with crinoid coluranals; lower contact disconformable. 11.6

4. Limestone, arenaceous, medium-gray, finely crystalline; and calcareous sandstone and medium- to fine-grained quartz-pebble conglonerate; basal foot is a quartzpebble conglomerate; many scat tered crinoid columnals; basal contact disconformable................... 5.0

3. Sandy limestone and calcareous sandstone; medium-gray; weathers tan gray; 1-2 ft. above base occurs first crossbedded sandstone; 2-3 ft. above base blue-black chert pods up to $\frac{1}{2} \mathrm{ft}$. Iong and $0.3 \mathrm{ft}$. thick; 3-4 ft. above base crossbedded sandstone and mediumgrained conglomerate; scattered crinoid columnals; lower contact concealed........................ 6.0

Total thickness Stormille Member............ 26.6

Shawnee Island Hember:

2. Covered................................... 4.5

1. Linestone, arenaceous and argillaceous, moderately crystalline, medium-gray, weathers tan gray; unit 
Coeymans Formation (part)-Continued

Thickness

Shawnee Island Member--Continued

forms ledge; crinoid columnals and Gypidula.

cooymanensis; base concealed.................. $\quad \underline{6.0}$

Incomplete thickness of Shawnee Island Member...

\section{Section 5}

Stornville and Shawnee Island Members of the Coeymans Formation at Hartman's Cave, altitude of 650 feet on the southeast slope of Godfrey Ridge, 0.85 mile northeast of the Stormville Church, at crest of overturned anticline, Stroudsburg quadrangle, Pennsylvania.

Coeymans Formation (part):

Stormville Member:

11. Conglomerate, medium-light-gray, calcareous, slightly limonitic; well-rounded to subrounded milky quartz pebbles; weathers light-tannish gray; scattered crinoid columnals and Gypidula coeymanensis; basal contact disconformable......................

10. Sandstone, medium-light-gray, calcareous, mediumgrained; weathers light-tannish gray; juxtaposed with medium-gray fine-grained arenaceous and argillaceous limestone which weathers mediur light gray; abundant crinoid columnals; basal contact abrupt................................

9. Sandstone, medium-light-gray, coarse-grained, calcareous; weathers light-tamish gray; thin quartz-pebble conglomerate at base; crossiedded; abundant crinoid columnals as much as $1 / 8$ in. in diameter; basal contact disconformable.........

8. Sandstone and limestone. Sandistone is mediumlight-gray, medium-grained, argillaceous, calcareous; weathers tannish gray. Limestone is medium gray, fine grained, arenaceous and argillaceous; weathers medium-1ight gray; $30-40$ percent quartz sand. Basal $1.5 \mathrm{ft}$. medium- to coarse-grained sandstone; basal contact

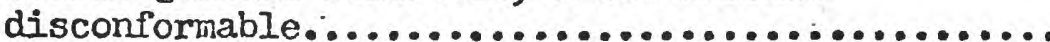

7. Limestone, medium-gray, fine-grained, arenaceous and argillaceous; weathers medium-light gray; abundant crinoid columnals; basal contact abrupt...........

6. Chext, dark-gray, bedded; basal contact abrupt...... .2 
5. Limestone; similar to unit 7; about 20 percent quartz sand; weak fracture cleavage; irregularly bedded; basal foot contains nodules of dark-gray chert; brachiopods and crinoid columnals abundant; basal contact disconformable...................... 8.1

4. Conglomerate, medium-light-gray; rounded to subrounded milky quartz pebbles, calcareous; weathers lighttannish gray; basal contact disconfornable.........

3. Limestone; similar to unit 7; about 30 percent quartz sand; weak fracture cleavage; irregularly bedded; 3-in. siltstone bed $2 \mathrm{ft}$. above base; upper $0.4 \mathrm{ft}$. dark-gray chert band; basal contact disconformable.. 4.0

2. Conglomerate; similar to unit 4 ; basal contact disconformable................................

Total thickness of Stormville Member.......... 24.7 Shawnee Island Member (part):

1. Limestone, medium-gray, fine- to medium-grained, argillaceous and arenaceous; weathers medium-lighttannish gray; irregularly bedded; weak fracture cleavage; slightly limonitic; abundant valves of Gypidula coeymanensis; basal contact concealed..... 13.5

Incomplete thickness of Shawnee Island Member.. 13.5

Incomplete thickness of Coeymans Formation.... 38.2

\section{Section 6}

Minisink Limestone, New Scotland Formation, and Coeymans Formation, northeast bank of Brodhead Creek at Minisink Hills, Stroudsburg quadrangle, Pennsylvania. Section begins just southeast of collapsed bridge. Bedding dips $40^{\circ} \mathrm{NW}$., on the average.

\section{Minisink Limestone (part):}

13. Limestone, medium-gray, fine- to medium-grained, argillaceous; weathers medium-light gray; irregularly bedded; weak fracture cleavage; fossils abundant and include brachiopods, bryozoans, and coral fragments; basal and upper contacts concealed.............. 7.0 
New Scotland Formation:

311

Maskenozha Hember:

12. Covered.................................. 10.0

11. Shale, dark-gray, slightly calcareous and siliceous; weathers mediun gray; scattered pods of medium-darkgray dense argillaceous limestone in upper $10 \mathrm{ft} . ; \mathrm{a}$ few beds of purer limestone in upper $10 \mathrm{ft}$; laminated; conspicuous fracture cleavage; basal $12 \mathrm{ft}$. contain about 10 percent beds and lenses of medium-gray fine-grained argillaceous fossiliferous limestone; fossils abundant and include Macropleura macropleura, Leptaena "rhomboidalis" and other brachiopods, trilobites, bryozoans, corals, ostracodes, and crinoid columnals; basal contact abrupt and placed at top of first dowmward

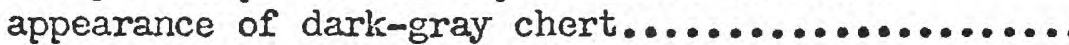

Total thiclness of Maskenozha Hiember........ 43.0

Flatbrookville Member:

10. Shale, dark-gray, slightly calcareous and siliceous; woathers medium gray to medium-light gray; about 10-15 percent lenses and nodules of dark-gray chert; about 10 percent lenses, nodules, and beds of medium-dark-gray fine-grained argillaceous fossiliferous limestone; unit abundantly fossiliferous, having Macropleura macropleura, Leptaena "rhomboidalis," and other brachiopods, bryozoans, trilobites, ostracodes, and crinoid coluanals; lenses of fine quartz sand as much as $0.5 \mathrm{ft}$. wide and 1-2 in. thick at upper contact;

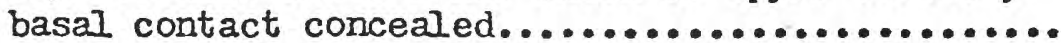

9. Covered.................................. 7.5

8. Shale, similar to unit 10; basal contact concealed... 5.5

7. Covered.................................. 3.0

Total thickness of Flatbrookville Member........ 33.0

Total thickness of New Scotland Formation....... 76.0 
Coeymans Formation (part):

Stormville Member:

6. Sandstone, medium-light-gray, fine- to coarsegrained, calcareous; weathers light tamish gray to orange gray; crossbedded; massive;

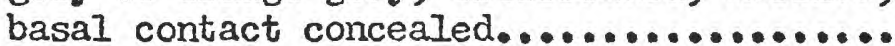

5. Covered.

4. Sandstone, conglomerate, and arenaceous limestone lenses juxtaposed, medium-light-gray to mediumgray; weathers light tannish gray; crossbedded; sand and conglonerate stand out in relief upon weathering; scattered crinoid columnals and Gypidula coeymanensis; basal contact disconformable.......................................

Shawnee Island Member (part):

3. Limestone, medium-gray, fine-grained, arenaceous and argillaceous; weathers medium light gray; irregularly bedded; unit consists of about 20 percent quartz sand; fossils abundant, crinoid coluranals and Gyoidula coeimanensis; basal contact abrupt... 2.0

2. Limestone; similar to unit 3, but scattered nodules of dark-gray chert make up about 5 percent of unit; basal contact abrupt........................

1. Chert, dark-gray, lenticular, 0.5-1 ft thick....... 1.0 Incomplete thickness of Shawnee Island Member. $\underline{5.0}$ Incomplete thickness of Coeymans Forration.... 21.? 
Ridgeley Sandstone and Shriver Chert of the Oriskany Group, Port Even Shale, and Mini.sink Limestone, in roadcut on scuthrest side of U.S. Interstate Highway 80 , approximately 0.4 mile scuthwest of Minisink Hills, Stroudsburg quadirangle, Pennsylvania. Section begins at road level in the upper beds of the Maskenozha Nember of the New Scotland Formation and contimes uphill along a construction bench to the top of the Oriskany Group. Section lies along an overturned symcline.

Oriskany Group:

Thickness

Ridgeley Sandstone:

28. Sandstone, light-gray, fine- to medium-grained, calcareous; weathers bromish orange; grains Fell rounded to subrcunded; leached; brachiopods abundant; bassl contact disconformable..............

27. Conglomerate and 3sndstone, light-gray, calcarecus; werthers orange gray; grains Eubangular to rounded; milky guartz pebbles as much as 0.5 in. long; unit coarser toward top; massively bedded; low-engle. crossbeciding; forms ledge at tep of rozdcut and weathers into large blocks; scattered brachiopod fragnents; basal contact gradational................

26. Sandstone, medium- to light-gray, fine- to coarsegrained, calcarecus; weathers orange gray; basal contact abrupt..............................

25. Sandstone, light-gray, coaree-grained, calcareous; weatrers orange gray; grains subangular to rounded; limonitic; scattered dark-gray chert nodules; lowangle crossbedding and horizontal laminations; brachiopod framents; basal contact disconformable..

24. Sandstone, medium-gray, fine-grained, silty, calcarecus; weathers light-tannish gray to orange gray; magoive; sparingly fossiliferous; basal contact gradational..................................

23. Conglcmerate, light-gray, fine-grained, calcareous; weatherd orange gray; basal contact disconformable..

Total thickness of Ridgeley Sandetone......... 15.9 
22. Limestone, medium-gray, fine-grained, arenaceous and argillaceous; weathers tannish gray; nodules and lenses of dark-gray chert; sparingly fossiliferous; basal coniact disc onformable...................

21. Conglomerate and sandstone; similar to unit 27; basal contact disconformable...................

20. Chert, dark-gray; scattered lenses of mediur-gray fine-graincd argillaceous limestone; basal contact disconformable.............................

19. Conglomerate and sandstone; similsr to unit 27; basal contact disconformable...................

18. Chert, darh-gray; Ienses of medium-gray fine-grained argillaceous fossiliferous limestone and sandstone; partly burrowed; basal contact disconformable......

17. Conglomerate and sandstone; similar to unit 27; milky quartz pobbles as much as $0.5 \mathrm{in}$. long; horizontally bedded to lcw-angle crossbedding; detrital chert; basal contact disconfcrmable...................

16. Chert, dark-gray; brachiopod shell hashe3, dominantly spiriferid brachiopods, shell material composed of coarse-grained calcite which leaches upon weathering leaving nurerous molds; coarse-grained calcareous sandstone as mich as $0.6 \mathrm{ft}$. thick; unit contains detrital chert; laminations in fine-grained sandstone; basal contact disconformable...............

15. Chert, dark-gray; basal contact disconformable....... .8

14. Sandstone and conglomerate. Sandstcne coarse-grained; conglomerate calcareous. Unit become finer grained towara top; low-angle crossbedding; basal contact disconformable................................

13. Chert, dark-gray, massive; nodules and lenses of medłum-dark-gray fine-grained siliceous limestone; unit poorly fossiliferous; burrow mottles in limestone and chert; basal contact disconformable...... 
12. Sandstone and conglomerate. Sandstone coarse

grained; conglomerate fine grained, calcarecus. Grains subengular to rounded. Horizontally bedded to low-angle cross-stratification. Unit variable in thickness; fossils rare; basal contact disconformable.

11. Chert and calcisiltite. Chert is dark gray and occurs as irregular beds and pods; spiriferid brachiopod hashes. Calcisiltite is medium-dark gray, fine grained, siliceous. A 5-in. thick coarse to very coarse sandstone occurs near top of unit. Many burrow mottles in fine-grained beds; basal contact at bese of fos il hesh 00000000000000000000000

10. Iimestone, medium-dark-gray, fine-grained, silty,

\section{- siliceolls; rieathers light gray to medium gray; massively bedded; nodules and lenses of dark-gray
chert; trilobites locally abundant; very fossilifer- massively bedded; nodules and lenses of dark-gray
chert; trilobites locally abundant; very fossilifer- ous; abundant burrovr mottles; basal contact placed at tcp of brachiopod hash.......................}

9. Iimestone, medium-dark-gray, fine-grained, argillaceous, silty, siliceous; weathers light-tarnigh gray; irregularly bedcied; burrow mottled; chert intraclasts; many spiriferid brachiopods; basal contact placed at base of brachiopod hash.......... 20.7

8. Chert, dark-gray; about 40 percent dark-gray siliceous shale with pockets of dark-gray finegrained poorly fossiliferous limestone; burrow mottled; basal contact gradational................

7. Chert, dark-gray; nodules and lenses of medium-darkgray fine-Erained siliceous and argillaceous limem stone and calcareous shale; poorly fossilifercus; basal contact sharp, placed at first appearance of dark-gray chert...............................

Total thickness of Shriver Chert..............

Total thickness of Oriskany Group............. 
6. Shale, calcareous, silty, siliceous, medium-darkgray; weathers light-tannish gray; slightly pyritic; irregularly bedded; conspicuous cleavage; fossiliferous, having corals, brachiopods, ostracodes, trilobites, and crinoid colunnals; more calcareous beds contain abundant small burroHs (about $\frac{3}{4}$ in. in diameter); basal contact gradational and marked by increase in silt.............

5. Shale, medium-dark-gray, silty, calcareous; weathers Ilght-tannish gray; pyritic; conspicuous cleavage; massively bedded; scattered brachiopods and corals; unit contains fewer silty laminae than underlying unit; basal contact gradational....................

4. Shale, medium-dark-gray, silty, calcareous; weathers light-tannish gray; slightly pyritic; irregularly laminated, because of alternations of silty and less silty beds; poorly fossiliferous; fossils dismuted by cleavage; more calcareous beds have rare burrcws; basal contact at 1-ft. -wide calcite-filled fault zone, displacement probably not more than a few feet......................................

3. Shale, medium-dark-gray, silty, calcareous; weathers light-tannish gray; irregularly Iaminated, owing to alternations of silty and less silty beds; poorly fossiliferous; basal contact abrupt...............

Total thickness of Port Ewen Shale........... 150.7

\section{Minisink Limestone:}

2. Limestone, medium-gray, fine-grained argillaceous; weathers light-tannish gray; irregularly bedded; beds as much as $3 \mathrm{ft}$. thick; thin interbeds of calcareous shale; fracture cleavage; fossils mostly fragmental and include corals, bryozoans (mainly fenestellids), brachiopods, and crinoid columnals; basal contact sharp........................... 14.0

Total thickness of Minisink Limestone........ 14.0 
New Scotland Formation (thickness not measured) :

Maskenozha Member (thickness not measured):

(feet)

1. Shale, dark-gray, calcareous and siliceous; weathers medium-light-tannish gray; laminated; poorly exposed.

\section{Section 8}

Esopus and Schoharie Formations and Foxtorn Member of the Buttermilk Falls Limestone in roadcut along U.S. Route 209 near Buttermilk Falls, East Stroudsburg quadrangle, Pennsylvania. Beds dip gently to south.

\section{Buttermilk Falls Iimestone (part):}

Foxtown Member (part):

5. Limestone, medium-gray, silty, containing large crinoid columnals as much as l in. in diameter; weathers light gray and buff. Irregular chert lenses and pods as much as 5 in. long concentrated in more calcareous beds. Irregular wavy-bedded and interbedded calcarenite (as much as 5 in. thick) and calcilutite. Calcilutite is the minor component (approximately 25 percent of unit) and occurs as thin lenses, laninae, and beds as much as 1 in. thick. Burrow mottled. Chert, dark-gray; calcarenite, medium-gray, weathers medium-light gray to light gray; calcilutite, medium-dark-gray, weathers medium gray. Chert makes up about 5 percent of unit near base. Chert replaces limestone; fossils and burrows are within chert. Chert forms halo around more calcareous segregations. Basal contact abrupt and is about $5 \mathrm{ft}$. above road level at culvert.

Incorplete thickness of Foxtown Member of the Buttermilk Falls Limestone...............

Schoharie Formation:

4. Siltstone, calcareous, massive, evenly bedded. Contains scattered dark-gray chert nodules and lenses as much as 2 in. thick in lower half and more abundant chert and limestone in upper half of unit. Chert makes up less than 5 percent of basal part of unit. Upper $15 \mathrm{ft}$. contains as much as 40 percent chert, enclosing irregular lenses of dark-gray to Erayish-black, fossiliferous (brachiopods), irregularly bedded, shaly siltstone. Lowest bed contains a 2-in.-thick grayishblack chert lens which is about $3 \mathrm{ft}$. long and about 
Schoharie Forration--Continued

4 in. above the base of unit; chert is more abundant above $31 \mathrm{ft}$. above base of unit. Above $51 \mathrm{ft}$. above base of unit beds become sandy (fine-grained sandy siltstone), more massive and blocky (beds as much as $6 \mathrm{ft}$. thick) and cleavage is poorly developed. Hore calcareous beds weather lighter gray than silty beds. Fossiliferous. Irregular lenses, beds, and pods of more calcareous calcisiltite somewhat burrow mottled with vertical shale-filled burrows approxjmately $\frac{1}{2}$ in. in diameter and 1-2 in. long. More extensively burrow mottled and less laminated toward top of unit. Contains scattered shale chips (inclined about $45^{\circ}$ to the horizontal) is as much as 2 in. long............... 66.0

3. Siltstone, calcareous, massive, evenly bedded; beds range from about 4 in. to 16 in. thick; fossiliferous....... 7.0

2. Siltstone, calcareous, dark-gray, massive, laminated; in beds from a fer inches to as much as $3 \mathrm{ft}$. thick; contains minor interbedded calcareous shaly siltstone; contact with Esopus is gradational. Base of Schoharie is placed at the first massive siltstone encountered going up section; cleavage is not as well developed as in the Esopus; when hit with a hammer the Schoharie yields a "firmer" ring as compared to duller sound of the Esopus; no chert; fairly well developed cleavae. Abundant Taonurus caudigalli. Unit becoraes more unevenly bedced and laninated and more calcareous toward top with interlensings of more calcareous coarser grained calcisiltite and less calcareous calcisiltite. Becomes slightly burrow mottled toward top. Most burrowing is horizontal..................

Thickness of Schoharie Formation............. 103.0

Esopus Formation (part, thickness not measured):

1. Dark-gray, highly cleaved shaly, laminated siltstone; calcareous locally and containing Taonurus caudigalli.

\section{Section 9}

Schoharie Formation and Foxtown, McMichael, and Stroudsburg Members of the Buttermilk Falls Limestone in railroad cut of the Erie-Lackawanna Railroad, I mile south of the East Stroudsburg post office, Stroudsburg quadrangle, Pennsylvanja. The center of the cut is in the Schoharie Formation and in the crest of an overturned anticline. Beds of the Buttermilk Falls Limestone to the north are overturned as much as $55^{\circ}$ to the southeast. 
6. Iimestone, medium-dark-gray, fine- to mediumcrystalline, medium-light-gray to light-grayweathering, irregularly interbedded and lenticular, fossiliferous; and grayish-black to dark-gray chert. Beds and lenses about $I \mathrm{in}$. to $\mathrm{l} \mathrm{ft}$. thick. Chert and limestone in about equal proportions. Upper $15 \mathrm{ft}$. contains three beds that are $3 \mathrm{in}$. to 6 in. thick of medium-gray to medium-light-gray, light-gray-weathering, medium- to very coarsely crystalline limestone with abundant brachiopod debris. Contact with overlying Union Springs Member of the Marcellus Shale not exposed but is probably close.

5. Shale, calcareous, medium-gray, silty, with some medium-gray to medium-light-gray, light-grayweathering, fine- to medium-crystalline limestone pods up to 2 in. in diameter......................

4. Limestone, medium-gray to medium-dark-gray, light-gray to medium-light-gray-weathering, finely to mediumcrystalline, locally argillaceous and fossiliferous; in irregular beds, lenses, and pods $I$ in. to I ft. thick, and dark-gray to grayish-black chert in irregular pods, lenses, and discontinuous beds $\frac{1}{4}$ in.

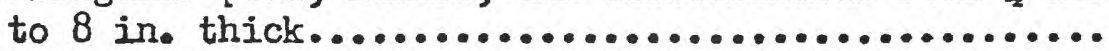

Thickness of Stroudsburg Hember............. 1149.0

McMichael Member:

3. Shale, medium-gray to medium-dark-gray, medium-grayweathering, calcareous, partly silty, evenly bedded to lenticular, fossiliferous; in beds $2 \mathrm{in}$. to $1 \mathrm{ft}$. thick; interbedded with medium-gray finely crystalline limestone in beds, lenses, and nodules 1 to 3 in. thick. Limestone contains ostracoies and brachiopod and crinoid debris. Contact with overlying Stroudsburg Hember gradational and marked by appearance of chert and disappearance of argillaceous beds....... 41.0

Total thickness of McMichael Member............. ㄴ...0

Foxtown Hember:

2. Linestone, medium-gray to medium-dark-gray, light-gray to medium-light-gray-weathering, finely to very coarsely crystalline, irregularly bedded to lenticular, in beds 1 in. to $2 \mathrm{ft}$. thick, interbedded 
Buttermilk Falls Limestone--Continued

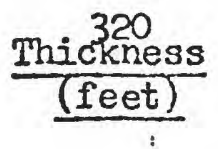

Foxt own Member-m-Cont inued

with medium-dark-gray, calcareous, evenly bedded shale and siltstone in beds 1 in. to $1 \mathrm{ft}$. thick, and grayish-black to dark-gray chert. Chert in lower half occurs as irregular nodules $\frac{1}{2}$ in. to 6 in. in diameter. Chert becomes more abuncant in upper half where it makes up more than 50 percent of unit and contains interbeds of calcareous argillite 1-2 in. thick and limestone pods 2-6 in. in dianeter. Large crinoid columnals with cross-sectional diameters up to 1 in. are conspicuous in lower half. Abundant ost racodes. Base marked by 1-ft.-thick, mediun-gray, light-gray-weathering, medium- to very coarse grained limestone in abrupt contact with underlying Schoharie. Contact with overlying Mcilichael Menber transitional

over 4 -ft. interval........................ 82.0

Total thickness of Foxtown Member............ 82.0

Total thickness of Buttermilk Falls Limestone.... 272.0

Schoharie Formation (part):

1. Siltstone, mediun-gray to mediun-dark-gray, finely sandy to argillaceous, calcareous to noncalcareous; in beds up to $5 \mathrm{ft}$. thick. Becomes sandier towards top. Base not exposed...................... 58.0

Incomplete thickmess of Schoharie Formation... 58.0 
Allen, J. R. I, 1965a, A review of the origin and characteristics of Recent alluvial sediment: Sedimentology, v. 5, p. 89-19l.

19650, Fining-upward cycles in alluvial successions: Liverpool and Manchester Geol. Jour., v. 4, p. 229-246.

Alvord, D.C., and Drake, A. A., Jr., Geologic map of the Bushkill quadrangle, Pennsylvania-New Jersey: U.S. Geol. Survey Geol. Quad. Map GQ-908 (In press).

American Cotmission on Stratigraphic Nomenclature, 1961, Code of strat1graphic nomenclature: Am. Assoc. Petroleum Geologists Bull., v. 45, p. 645-665.

Amsden, T. W., 1955, Lithofacies map of Lower Silurian deposits in central and eastern United States and Canada: Am. Assoc. Petroleum Geologists Bull., v. 39, p. 60-74.

Arndt, H. H., and Wood, G. H., 1960, Late Paleozoic orogeny in eastern Pennsylvania consists of five progressive stages: U.S. Geol. Survey Prof. Paper 400-B, p. B182-B184.

Ashley, G. H., 1935, Studies in Appalachian Mountain sculpture: Geol. Soc. America Bull., v. 46, p. 1395-1436.

Barnett, S. G., III, 1965, Conodonts of the Jacksonburg Limestone (Middle Ordovician) of northwestern New Jersey and eastern Pennsylvania: Milcropaleontology, v. 11, p. 59-80.

Bates, T. F., 1947, Investigation of the micaceous minerals in slate: Am. Mineralogist, v. 32, p. 625-636.

Becker, H. F., and Donn, William, 1952, A new occurrence and description of the fossil Arthrophycus: Science, v. 115, p. 214-2l5.

Beerbower, J. R., 1956, The Ordovician-Silurian contact, Delaware Water Gap, New Jersey: Pennsylvania Acad. Sc1. Proc., v. 30, p. 146-149.

1957, Paleontology of the Centerfield coral zone, East Stroudsburg locality, Monroe County, Pennsylvania: Pennsylvanta Acad. Sc1. Proc., v. 31, p. 91-97. 
Beerbower, J.R., and Ha1t, M. H., Jr., 1959, Silurian fish in northeastern Pennsylvania and northern New Jersey: Pennsylvania Acad. Sci. Proc., v. 33, p. 198-203.

Beerbower, J.R., and McDowell, F. W., 1960, The Centerfield biostrome: an approach to a paleoecological problem: Pennsylvania Acad. Sc1. Proc., v. 34, p. 84-91.

Behre, C. H., Jr., 1924, Structures in the slates of Pennsylvania [abs.]: Geol. Soc. America Bull., v. 35, p. 100-101. 1927, Slate in Northampton County, Pennsylvania: Pennsylvania Geol. Survey, 4th ser., Bull. M9, 308 p.

1933, Slate in Pennsylvania: Pennsylvania Geol. Survey, 4th ser., Bull. Mn6, $400 \mathrm{p}$.

Berdan, J. M., 1964, The Helderberg Group and the position of the Silurian-Devonian boundary in North America: U.S. Geol. Survey Bull. 1180-B, 19 p.

Bernard, H. A., and LeBlanc, R. J., 1955, Résumé of the Quaternary geology of the northwestern Gulf of Mexico province, in Wright, H. E., and Frey, D. G., eds., Quaternary of the United States: Princeton, N.J., Princeton UnIv. Press, p. 137-185.

Bernard, H. A., and Major, C.F., 1963, Recent meander belt deposits of the Brazos River: an alluvial "sand" model [abs.]: Am. Assoc. Petroleum Geologists Bull., v. 47, p. 354.

Bird, J. M., and Dewey, J. F., 1970, Iithosphere plate-continental margin tectonics and the evolution of the Appalachian orozen: Geol. Soc. America Bull., v. 81, p. 1031-1060.

Braddock, W. A., 1970, The origin of slaty cleavage: evidence from Precambrian rocks in Colorado: Geol. Soc. America Bull., v. 81, p. $589-600$.

Broughton, J.G., 1946, An example of the development of cleavages: Jour. Geology, v. 54, p. 1-18.

Carson, W. P., 1968, Development of flow cleavage in the Martinsburg Shale, Port Jervis South area (northern New Jersey): Tectonophysics, v. 5, p. 531-541.

Chance, H. M., 1882, Special survey of the Delaware Water Gap, in White, I. C., The geolocy of Plke and Monroe Counties: Pennsylvania Geol. Survey, 2d ser., Rept. G6, 407 p. 
Clark, B. R., 1969, The origin of slaty cleavage in the Coeur D'Alene district, Idaho [abs.]: Geol. Soc. America, Abstract with Programs, pt. 5, Salt Lake C1ty, Utah, p. 13-14.

Clark, T. H., 192l, A review of the evidence for the Taconic revoIution: Boston Soc. Nat. History Proc., v. 36, no. 3, p. $135-163$.

Clarke, J. M., 1885, A brief outline of the geological succession in Ontario Co., New York: New York State Geologist, Ann. Rept. 4, p. 9-22.

1903, Classification of New York series of geologic formations: New York State Mus. Handbk. 19, $28 \mathrm{p}$.

Clarke, J. M., and Ruedemann, Rudolf, 1912, The Eurypterida of New York: New York State Mus. Mem. 14, $439 \mathrm{p}$.

Clarke, J. M., and Schuchert, Charles, 1899, The nomenclature of the New York series of geological formations: Sclence, n. ser., v. 10 , no. 259, p. $874-878$.

Cleaves, A. B., 1937, Oriskany thicknesses in Pennsylvania: Pennsylvenia Acad. Sci. Proc., v. 11, 2. 64-71.

1938, Discussion to conditions of sedimentation and sources of the Oriskany Sandstone as indicated by petrology, by Marcellus H. Stow: Am. Assoc. Petroleum Geologists Bull., v. 22 , p. $2108-1111$.

1939, The Oriskany Group, in The Devonian of Pennsylvania: Pennsylvania Geol. Survey 4th ser., Bull. G-19, p. 92-130.

Coleman, J. M., and Gagliano, S. M., 1965, Sedimentary structures: Mississippi River deltaic plain, in Middleton, G. V., ed., Primary sedimentary structures and their hydrodynamic interpretation: Soc. Econ. Paleontologists and Mineralogists Spec. Pub. 12, p. 133-148.

Conrad, T. A., 1842, Observations on the Silurian and Devonian Systems of the United States, with descriptions of new organic remains: Philadelphia Acad. Nat. Sc1. Jour., v. 8, pt. 2, p. $228-280$.

Cook, G. H., 1868, Geology of New Jersey: Newark, 899 p.

Cooper, G. A., 1930, Stratigraphy of the Hamilton Group of New York: Am. Jour. Sc1., 5th ser., v. 19, p. 116-134, 214-236. 
poper, G. A., 1941, New Devonian stratigraphic unfts: Washington Acad. Sc1. Jour., v. 31, no. 5, p. 179-181.

Cooper, G. A., and others, 1942, Correlation of the Devonian sedimentary formations of North America: Geol. Soc. America BuIl., v. 53, p. $1729-1794$.

Cramer, F. H., 1969, Possible 1mplications for Silurian paleogeography from phytoplankton assemblages of the Rose Hill and Tuscarora Formations of Pennsylvania: Jour. Paleontology, v. 43, p. 485-491.

Cuthbert, F. I., 1946, Differential thermal analysis of liew Jersey clays: New Jersey Dept. Conserv., Misc. Geol. Paper, 20 p.

Dahlstrom, C. D. A., 1969, The upper detachment in concentric folding: Canadian Petroleum Geology Bull., v. 17, p. 326-346.

Dale, T. N., and others, 1906, Slate deposits and slate industry in the United States: U.S. Geol. Survey Bull. 275, 154 p.

1914, Slate in the United States: U.S. Geol. Survey BuIl. $586,220 \mathrm{p}$.

Darton, N. H., 1894, Thirteenth ennual report of the New York Geological Survey: New York State Geol. Survey Ann. Rept. 13 , p. 209-302.

1896, Description of the Franklin quadrangle [West Virginia]: U.S. Geol. Survey Geol. Atlas, Folio 32.

Devis, R. E., Drake, A. A., Jr., and Epste1n, J. B., 1967, Geology of the Bangor quadrangle, Pennsylvania-New Jersey: U.S. Geol. Survey Geol. Quad. Map GQ-665.

Dieterich, J. H., 1969, Origin of cleavage in folded rocks: Am. Jour. Sc1., v. 267, p. 155-165.

Doeglas, D. J., 1962, The structure of sedimentary deposits of braided rivers: Sedimentology, v. 1, p. 167-190.

Donaldson, A. C., 1966, Deltaic sands and sandstones, in Wyoming Geol. Assoc., 20th Ann. mtg., Symposium on recently developed geologic principles and sedimentation of the Permo-Pennsylvanian of the Rocky Mountains: Wyoming Geol. Assoc., 20 th Ann. Mtg., Casper, Wyo., p. 31-62.

Donath, F. A., and Parker, R. B., 1964, Folds and folding: Geol. Soc. Amerlca Bull., v. 75, p. 45-62. 
Drake, A. A., Jr., 1967a, Geologic map of the Easton quadrangle, New Jersey-Pennsylvan1a: U.S. Geol. Survey Geol. Quad. Kap GQ-594.

1967b, Geologic map of the Blootnsbury quadrangle, Hew Jersey: U.S. Geol. Surrey Geol. Quad. Map GQ-595.

1969, Precarbrian and lower Paleozolc geology of the Delaware Valley, Hew Jersey-Pennsylvania, In Subltzky, Seymour, ed., Geology of selected areas in New Jersey and eastern Pennsylvania and guidebook of excursions: New Brunswick, N.J., Rutgers Univ. Press, p. 51-131.

1970, Structural geology of the Reading Prong, in Fisher, G. W., Pettifohn, F. J., Reed, J. C., Jr., and Weaver, K. N., eds., Studies of Appalachian geology--central and southern: Hew York, John Wiley and Sons, p. 271-291.

Drake, A. A., Jr., Davis, R. E., and Alvord, D. C., 1960, Taconic and post-Taconic folds in eastern Penusylvania and western New Jersey: U.S. Geol. Survey Prof. Paper 400-B, p. B180-B181.

Drake, A. A., Jr., and Epstein, J. B., 1967, The Martinsburg Fontation (Middle and Upper Ordovician) in the Delaware Valley, Pennsylvanla-New Jersey: U.S. Geol. Survey Bull. 1244-B, p. BI-HI6.

Dreke, A. A., Jr., Epstein, J. B., and Aaron, J. M., 1969, Geologic rap and sections of parts of the Portland and Belvidere quadrangles, New Jersey-Pennsylvania: U.S. Geol. Survey Misc. Geol. Inv. Map I-552.

Drake, A. A., Jr., Kclaughlin, D. B., and Davis, R. E., 1961, Geology of the Frenchtown quadrangle, New Jersey-Pennsylvania: U.S. Geol. Survey Geol. Quad. Hap GQ-133.

1967, Geologic map of the Riegelsville quadrangle, Pennsylvania-Ner Jersey: U.S. Geol. Survey Geol. Qusd. Map GQ-593.

Eardley, A. J., 1951, Structural geology of North America: New York, Harper \& Bros., 624 p.

Ellison, R. L., 1965, Stratigraphy and paleontology of the Mahantango Formation in south-central Pennsylvania: Pennsylvania Geol. Survey, 4th ser., Bull. G-48, 298 p. 
Epstein, A..G., Epstein, J. B., Splnk, W. J., and Jennings, D. S., 1967, Upper Silurian and Lover Devonian stratigraphy of northeasterm Pennsylvania, New Jersey, and southeasternmost New York: U.S. Geol. Survey Buzl. 1243, 74 p.

Epstein, J. B., 1966, Structural control of wind gaps and water gaps and of stream capture in the Stroudsburg area, Pennsylvania and New Jersey: U.S. Geol. Survey Prof. Paper 550-B, p. $\mathrm{B} 80-\mathrm{B} 86$.

1969, Surficial geology of the Stroudsburg quadrangle, Pennsylvania-New Jersey: Pennsylvania Geol. Survey, 4th ser., Bull. G-57, 67 p.

Epstein, J. B., and Epstein, A. G., 1967, Geology in the region of the Delaware to Lehigh Hater Gaps, Fleld Conference of Fennsylvania Geologists, 32d, East Stroudsburg, Guidebook: Harr16burg, Pa., Pennsylvanfa Geol. Survey, 89 p.

1969, Geology of the Valley and Ridge province between Delaware Water Gap and Lehigh Gap, Pennsylvania, in Subitzky, Seymour, ed., Geology of selected areas in New Jersey and eastern Pennsylvania and guidebook of excursions: New Brunswick, N.J., Rutgers Univ. Press, p. 132-205.

Epstein, J. B., and Hosterman, J.W., 1969, Residual cley deposits in rocks of Early and Middle Devonian age near Kunkletown, Pennsylvania: U.S. Geol. Survey Prof. Paper 650-D, p. Dg4D105.

Evans, Graham, 1965, Intertidal flat sediments and their environments of deposition in the Wash: Geol. Soc. London Guart. Jour., v. 12l, p. 209-245.

Fahnestock, R. K., 1963, Morphology and hydrology of a glacial stream--White River, Mount Rainier, Washington: U.S. Geol. Survey Prof. Paper 422-A, $70 \mathrm{p}$.

Fahnestock, R. K., and Haushild, H. L., 1962, Flume studies of the transport of pebbles and cobbles on a sand bed: Geol. Soc. Amer1ca Bull., v. 73, p. 1431-1436.

Falll, R. T., 1969, Kink band structures in the Valley and Ridge province, central Pennsylvania: Geol. Soc. America Bull., v. 80 , p. $2539-2550$.

Fellows, R. E., 1943, Recrystallization and flowage in Appalachian quartzite: Geol. Soc. America Bull., v. 54, p. 1399-1432. 
eld Conference of Pennsylvania Geologists, 25th, Lancaster, 1960, Some tectonic and structural problems of the Appalachian piedmont along the Susquehanna River, by O. P. Bricker, A. A. Bopson, M. E. Kauffman, D. M. Lapham, D. B. McLaughlin, and D. U. Wise: Lancaster, Pa., Franklin and Marskall College, $99 \mathrm{p}$.

Field Conference of Pennsylvania Geologists, 3lst, karrisburg, 1966, Comparative tectonics and stratigraphy of the Cumberland and Lebanon Valleys, by D. B. Maclachlan and S. I. Root: Harrisburg, Pa., Pennsylvenia Geol. Survey, 90 p.

Fisher, D.'W., 1960, Correlation of the Silurian rocks in New York State: New York State Nus. and Sci. Service Map and Chart Ser. no. 1 .

Folk, R. L., 1960, Petrography and origin of the Tuscarora, Rose Hill, and Keefer Forwations, Lower and Middle Silurian of eastern West Virginia: Jour. Sed. Petrology, v. 30, p. 1-58.

Friedman, G. M., and Johnson, K. G., 1966, The Devonian Catskill deltaic complex of New York, type exarple of a "tectonic delta complex," In Shirley, M. L., ed., Deltas in their geologic framework: Houston, Houston Geol. Soc., p. 171-188.

Geiger, H. R., and Keith, Arthur, 1891, The structure of the Blue Ridge near Harper's Ferry: Geol. Soc. Awerica Bull., v. 2, p. 155-164.

Goldring, Winifred, and Flower, R. H., 1942, Restudy of the Schoharie and Esopus Formations in New York State: Am. Jour. Sc1., v. 240, p. 673-694.

Grabau, A. W., 1906, Guide to the geology and paleontology of the Schaharle Valley in eastern New York: New York State Mus. Bull. 92, p. 77-386.

1909, The Medina and Shawangunk problems in Pennsylvania. [abs.]: Science, n. ser., v. 30, p. 415.

1913, Early Paleozolc delta deposits of North America: Geol. Soc. America Bull., v. 24, p. 399-528.

Gray, Carlyle, 1954, Recumbent folding in the Great Valley: PennBylvania Acad. Sc1. Proc., v. 28, p. 96-101.

Gray, Carlyle, and others, 1960, Geologic map of Pennsylvania: Pennsylvania Geol. Survey, 4th ser., scale 1:250,000. 
Gwinn, V. E., 1964, Thin-skinned tectonics in the Plateau and northwestern Valley and Ridge provinces of the central Appalachians: Geol. Soc. America Bull., v. 75, p. 863-900.

Hall, James, 1839, Report of the fourth geological district of the State of Hew York: New York State Geol. Survey 3d Ann. Rept., p. 287-339.

Hansen, Edward, and Borg, I. Y., 1962, The dynamic significance of defornation lamellae in quartz of a calcite-cemented sandstone: Am. Jour. Sc1., v. 260, p. 321-336.

Hätzschel, Walter, 1939, Tidal flat deposits (Wattenschlick), in Trask, P. D., ed., Recent marine sediments, a symposium: Tulsa, Okla., Am. Assoc. Petroleum Geologists, p. 195-206.

1962, Trace fossils and problematica, in loore, R. C., ed., Treatise on Invertebrate Paleontology, $\overline{\mathrm{pt}}$. $\mathrm{W}$, Miscellanea: Lawrence, Kansas, Geol. Soc. America and Univ. Kansas Press, p. W $277-$ W245.

Hartnagel, C. A., 1905, Notes on the Siluric or Ontaric section of eastern New York: New York State Kus. Bull. 80, p. 342358.

Helw1g, James, 1970, Slump folds and early structures, northeastern Newfoundland, Appalachians: Jour. Geology, v. 78, p. $172-187$.

Herpers, H. F., Jr., 1950, Progress report on a study of the Esopus Formation in New Jersey, southern New York, and northeastern Pennsylvania: unpub. manuscript, Lehigh Univ., Bethlehem, $\mathrm{Pa}$.

1951, The stratigraphy of the Rondout Limestone in New Jersey: New Jersey Dept. Conserv. Geol. Ser. Bull. 60, 14 p.

Hess, H. H., 1955, Serpentine, orogeny, and epeirogeny: Geol. Soc. Amer1ca Spec. Paper 62, p. 391-408.

Hills, B. S., 1963, Elements of structural geology: New York, John Wiley \& Sons, 483 p.

Horowitr, D. H., 1966, Bvidence for deltaic origin of an Upper Ordovician sequence in the centrel Appalachians, in Shirley, M. L., ed., Deltas in their geologic Iramework: F̈uston, Houston Geol. Soc., p. 159-169. 
Horowitz, D. H., 1969, Diagenetic reduction and alteration of the Upper Ordovician Oswego Formation in the central Appalachian Mountains [abs.]: Geol. Soc. America, 2and Ann. Mtg., Programs with Abstracts, pt. 7, Atlantic City, N.J., p. 108.

Hunter, R. E., 1970, Facies of iron sedimentation in the Clinton Group, in Fisher, G.W., Pettijohn, F. J., Reed, J. C., Jr., and Weaver, K. H., eds., Studies of Appalachian geology-central and southern: New York, John Wiley \& Sons, p. 101121.

Johnson, D. W., 1931, Streem sculpture on the Atlantic slope, a study in the evolution of Appalachian rivers: New York, Columbia Univ. Press, $142 \mathrm{p}$.

Johnson, D. W., Bascom, Florence, and Sharp, H. S., 1933, Geomorphology of the central Appalachians: Internat. Geol. Cong., 16th, United States, 1932, Guidebook 7, Excursion A-7 50 p.

Johnson, Helgi, and Fox, S. K., Jr., 1968, Dipleurozoa from Lower Silurian of North America: Science, v. 162, no. 3849, p. 119-120.

Johnson, J. H., 1957, The Schoharie Formation: a redefinition: unpub. Ph. D. thesis, Lehigh University, Bethlehem, Pa., 178 p.

1959, Schoharie Formation redefined [abs.]: Geol. Soc. America Bull., v. O, no. 12, pt. 2, p. 1624-1625.

Johnson, J. H., and Southard, J. B., 1962, The Schoharie Formation in southeastern New York: New York State Geol. Assoc., Guidebook to field trips, 34th Ann. Mtg., Port Jervis, N.Y., p. A7-A23.

Jones, T. H., and Cate, A. S., 1957, Preliminary report on a regional stratigraphic study of the Devonian rocks of Pennsylvania: Pennsylvania Geol. Survey, 4th ser., Special Bull. 8, 5 p.

Kehle, R. O., 1970, Analysis of gravity sliding and orogenic translation: Geol. Soc. America Bull., v. 81, p. 1641-1664.

Kelth, Arthur, 1894, Harpers Ferry, Ve.-W. Va.-Md.: U.S. Geol. Survey Geol. Atlas, Folio 10.

1923, Outlines of Appalachian structure: Geol. Soc. America Bull., v. 34, p. 309-380.

Kindle, E. M., 1912, The Onondaga fauna of the Allegheny region: U.S. Geol. Survey Bull. 508, 144 p. 
3, P. B., 1951, The tectonics of middle North America--middle North America east of the Cordilleran system: Princeton, N.J., Princeton Univ. Press, 203 p.

Land, L. S., and Hoyt; J. H., 1966, Sedimentation in a meandering estuary: Sedimentology, v. 6, p. 191-207:

Lelth, C. K., 1905, Rock cleavage: U.S. Geol. Survey Bull. 239, $216 \mathrm{p}$.

Lesley, J. P., 1892, A sumary description of the geology of Pennsylvania: Pennsylvania Geol. Survey, $2 d$ ser., v. 1719 p.

Lesley, J. P., and others, 1883, The geology of Lehigh and Northampton Counties: Pennsylvania Geol. Survey, 2d, Rept. D-3, 283 p.

Lewis, J. V., and Kummel, H. B., 1912, Geologic map of New Jersey: New Jersey Dept. Conserv. and Devel. Atlas Sheet no. 40, revised 1931 by H. B. Kürmel, and 1950 by M. E. Johnson, scale $1: 250,000$, with sections.

1915, The geology of New Jersey: New Jersey Geol. Survey Bul1. 14, 146 p.

Lowry, W. D., 1957, Irpllcations of gentle Ordovician folding in western Virginia: Am. Assoc. Petroleum Geologists Bull., v. 41, p. 643-655.

McBride, E. F., 1962, Flysch and associated beds of the Nartinsburgs Formation (Ordovician), central Appalachians: Jour. Sed. Petrology, v. 32, p. 39-91.

McKee, E. D., 1957, Primary structures in some Recent sediments: Am. Assoc. Petroleum Geologists Burl., v. 41, p. 1704-1747.

Mackin, J. H., 1941, Drainage changes near Wind Gap, Pennsylvania-a study in map interpretation: Jour. Geomorphology, v. 4, p. 24-53.

Mather, W. W., 1840, Report of the first geological district of the State of New York: New York Geol. Survey Ann. Rept. 4, p. 209-258.

Maxwell, J. C., 1962, Origin of slaty and fracture cleavage in the Delaware Water Gap area, New Jersey and Pennsylvania, in Geol. Soc. America, Petrologic studies: a volume in honor of $\bar{A}$. F. Buddington: New York, Geol. Soc. America, p. 281-311. 
Merriman, Mansfield, 1898, The slate regions of Pennsylvania: Stone, v. 17, p. 77-90.

Meyerhoff, H. A., and Olmstead, E. W., 1936, The origins of Appslachian drainage: Am. Jour. Sc1., 5th ser., v. 32, p. 21-42.

Miller, B. I., 1925, Mineral resources of the Allentown quadrangle, Pennsylvania: Pennsylvania Geol. Survey, 4th ser., A.tlas 206, $195 \mathrm{p}$.

1926, Taconic folding in Pennsylvania: Geol. Soc. America Bull., v. 37, p. 497-511.

Miller, B. L., Fraser, C. M., and Miller, R. L., 1939, Northarpton County, Pennsylvania, geology and geography: Pennsylvania Geol. Survey, 4 th ser., Bull. C48, $496 \mathrm{p}$.

Miller, B. L., and others, 1941, Lehigh County, Pennsylvania, geology and geography: Pennsylvania Geol. Survey, 4th ser., Bull. C39, 492 p.

Moench, R. H., 1966, Relation of S2 schistosity to metamorphosed clastlc dikes, Rangeley-Phillips area, Maine: Geol. Soc. America Bull., v. 77, p. 1449-1462.

1970, Premetamorphic down-to-basin faulting, folding, and tectonic dewatering, Rangeley area, vestern Maine: Geol. Soc. America Bull., v. 81, p. 1463-1496.

Moody-Stuart, M., 1966, High- and low-sinuosity stream deposits, with examples from the Devonian of Spitsbergen: Jour. Sed. Petrology, v. 36, p. 1102-1117.

Mosely, J. R., 1950, The Ondovician-Silurian contact near Kempton, Pa.: Pennsylvania Acad. Sc1. Proc., v. 24, p. 176-187.

N1chols, M. M., 1962, Hydrography and sedimentolosy of Sonoran Lagoons, Mexico [abs.]: Geol. Soc. America, Ann. Mítg., 1962, Houston, Texas, Program, p. IIOA-IIIA.

Offield, T. W., 1967, Bedrock geology of the Goshen-Greenwood Lake area, New York: New York State Mus. and Sc1. Service Map and Chart Ser. no. 9, 77 p.

Oliver, W. A., Jr., 1956, Stratigraphy of the Onondaga Limestone in eastern New York: Geol. Soc. America Bull., v. 67, p. 1441-1474. 
Oliver, W. A., 1962, The Onondiga Iimestone in southeastern Hew York: Hew York State Geol. Assoc., Guldebook to fleld trips, 34 th Ann. Mtg., Port Jervis, N.Y., p. A2-A6.

1964, A new species of rugose coral genus Nalivkinella from the Middle Devonian of eastern Pennsylvania: Jour. Paleontology, v. 38, p. $866-876$.

Oliver, W. A., Jr., and others, 1969, Correlation of Devonian rock units in the Appalachian basin: U.S. Geol. Survey 011 and Gas Inv. Chart $\mathrm{OC}-64$.

O'Neill, W: F., 1940, Stratigraphy and structure of Godfrey Ridge: Pennsylvania Acad. Sc1. Proc., v. 14, p. 45-49.

1941, Columnar Silurien Iimestone in Pennsylvania: Pennsylvania Acad. Sci. Proc., v. 15, p. 75-81.

Ore, H. T., 1964, some criteria for recognition of braided stream deposits: Wyoming Univ. Contr. Geology, v. 3, p. 1-14.

Peck, F. B., 1908, Geology of the cement belt in Lehigh and Northampton Counties, Pennsylvania: Econ. Geology, v. 3, p. $37-76$.

Pelletier, B. R., 1958, Pocono paleocurrents in Pennsylvania and Maryland: Geol. Soc. America Bull., v. 69, p. 1033-1064.

Pett1john, F. J., 1957, Sedimentary rocks: New York, Harper and Bros., $718 \mathrm{p}$.

Plicka, Miroslav, 1968, Zoophycos, and a proposed classification of sabellid worms: Jour. Paleontology, v. 42, p. 836-849.

Powell, C. MCA., 1969, Intrusive sandstone dykes in the Siamo Slate near Fegaunee, Michigan: Geol. Soc. America Bull., v. 80 , p. 2585-2594.

Prosser, C. S., 1892, The Devonian system of eastern Pennsylvania: Am. Jour. Sc1., 3rd ser., v. 44, p. 210-221.

Ramsey, J. G., 1967, Folding and fracturing of rocks: New York, McGraw-HiII, 568 p.

Reineck, H. E., and Singh, I. B., 1967, Primary sedimentary structures in the recent sediments of the Jade, North Sea: Narine Geology, v. 5, p. 227-235. 
Rickard, L. V., 1962, Late Cayugan (Upper Silurian) and Helderbergian (Lower Devonian) stratigraphy in New York: New York State Mus. Bull. 386, $157 \mathrm{p}$.

1964, Correlation of the Devonian rocks in New York State: New York State Mus. and Sci. Service Map and Chart Ser., no 4.

Rogers, H. D., 1838, Second annual report on the (1st) geological exploration of the State of Pennsylvania: Harrisburg, $93 \mathrm{p}$.

1858, The geology of Pennsylvanie; a government survey: Philadelphia, 2 v.: 586 and 1046 p.

Root, S. I., 1970, Structure of the northern terminus of the Blue Ridge in Pennsylvania: Geol. Soc. America Bull., v. 81, p. $815-830$.

Sames, C. W., 1966, Horphometric data of some Recent pebble associations and their application to ancient deposits: Jour. sed. Petrology, v. 36, p. 126-142.

Schamel, Steven, 1969, Microscopic configuration of slaty and fracture cleavage [abs.]: Geol. Soc. America, Abstracts with Programs, pt. 1, Albany, N.Y., p. 53-54.

Schuchert, Charles, 1916, Silurian formations of southeastern New York, New Jersey, and Pennsylvania: Geol. Soc. America Bull., v. 27, p. $531-554$.

Scott, W. H., Hansen, Edward, and Twiss, R. J., 1965, Stress analysis of quartz deformation lamellae in a minor fold: Am. Jour. Sc1., v. 263, p. $729-746$.

Sellacher, Adolf, 1955, Ecological significence of fossil tracks and trails [abs.]: Geol. Soc. America Bull., v. 66, p. 1663. 1967, Bathymetry of trace fossils: Marine Geology, v. 5, p. 413-428.

1968, Origin and diagenesis of the Oriskany Sandstone (Lower Devonian, Appalachians) as reflected in its shell fossils, in Muller, German, and Friedman, G. M., eds., Recent developments in carbonate sedimentology in central Europe: New York, Springer-Verlag, p. 175-185.

Shainin, V. E., 1950, Conjugate sets of en echelon tension fractures in the Athens Limestone at Riverton, Virginia: Geol. Soc. America Bull., จ. 61, p. 509-517. 
Phepard, F. P., and Lankford, R. R., 1959, Sedimentary facles from shallow borlngs in lower Mississippl Delta: Am. Assoc. Petroleum Geologists Bull., จ. 43, p. 2051-2067.

Shinn, E. A., Ginsburg, R. N., and Hloyd, R. M., 1965, Recent supratidal dolomite from Andros Island, Bahamas, in Pray, I. C., and Murray, R. C., eds., Dolomitization and Ilmestone diagenesis: Soc. Econ. Paleontologists and Mineralogists Spec. Pub. 13, p. 112-123.

Simons, D. B., and Richardson, E. V., 1962, The effect of bed roughness on depth-discharge relations in elluvial channels: U.S. Geol. Survey Water-Supply Paper 1498-E, 26 p.

Smith, N. D., 1967a, A stratigraphic and sedimentologic analysis of some Lower and Middle Silurian clastic rocks of the northcentral Appalachians: unpub. Ph.D. thesis, Dept. Geology, Brown Univ., Providence, R. I., $195 \mathrm{p}$.

19670, Lower and Middle Sllurian fluvial sedimentstion of the north-central Appalachians [abs.]: Geol. Soc. Acerica Ann. Mtg., Northeast Sec., Boston, Mass., Program, p. 57-58.

Smith, N. D., and Saunders, R. S., 1970, Paleoenvironments and their control of acritarch distribution: Silurien of eastcentral Pennsylvania: Jour. Sed. Petrology, v. 40, p. 324333.

Stevens, G. R., 1966, Analysis and paragenetic history of anthraxolite in Ordovician slate, eastern Pennsylvania, in American Conference on Coal Science, University Park, $\overline{\mathrm{Pa}}$., 1964, Coal Science: Am. Chem. Soc., Advances in Chemistry Ser. 55, p. 91-116.

Stormer, Leif, 1955, Merostomata, in Moore, R. C., ed., Treatise on Invertebrate Paleontology, $\overline{\mathrm{Pt}}$. P, Arthropoda 2: Lawrence, Kansas, Geol. Soc. America and Univ. Kansas Press, p. P4-P4l.

Stose, G. W., 1922, Topographic map of Delaware Water Gap (15minute quadrangle): U.S. Geol. Survey, text on back of map.

1930, Unconformity at the base of the Silurian in southeastern Pennsylvania: Geol. Soc. America Bull., v. 41, p. 629-658.

1950, Evidence of the Taconic sequence in the vicinity of Lehigh River, Pennsylvania: Am. Jour. Sc1., v. 248, p. 815819. 
St Gten, I. M. J. U. van, 1961, Sedimentation in tidal flet areas: Alberta Soc. Petroleum Geologists Jour., v. 9, p. $203-226$.

Strahler, A. N., 1945, Hypothesjs of stream development in the folded Appalachians of Pennsylvania: Geol. Soc. America Burl., v. 56, p. 45-88.

Swartz, C. K. 1913, Correlation of the Lower Devonian: Maryland Geol. Survey, Lower Devonian, p. 96-132.

Swartz, C. K., and Swartz, F. M., 1930, Age of the Shawangunk Conglomerate of eastern New York: Am. Jour. Sci., v. 20, p. 467-475.

Swartz, C. K., and others, 1942, Correlation of the Silurian formations of North America: Geol. Soc. America Bull., v. 53, p. 533-538.

Swartz, F. M., 1929, The Helderberg Group frcm central Pennsylvania to southwestern Virginie: Pennsylvania Acad. Sc1. Proc., v. 3, p. 75-89.

1939, The Keyser Iimestone and Helderberg Group, in Willard, Bradford, and others, The Devonian of Pennsylvania: Pennsylvania Geol. Survey, 4th ser., Bull. G-19, p. 29-91.

1942, Silurian and early Devonian studies in the middle Appalachiens: New York Acad. Sci. Trans., 2d ser., v. 4, p. 177190.

1548, Late Ordovician and Silurian facies, conditions of deposition and paleogeography in north-central Appalechians [abs.]: Am. Assoc. Fetroleum Geologists Bull., v. 32, p. 2160.

Swartz, F. M., and Swartz, C. K., 1931, Early Silurian formations of southeastern Pennsylvania: Geol. Soc. America Bull., v. 43, p. 62I-662.

1941, Early Devonian and Iate Silurian formations of southeastern Pennsylvania: Geol. Soc. America Bull, v. 52, p. $1120-1192$.

Thompson, A. M., 1970a, Lithofacies and formation nomenclature in Upper Ordovician stratigraphy, central Appalachians: Geol. Soc. Americe Bull., v. 81, p. 1255-1260. 
Ward, Freeman, 1937, The Kartinsburg of the Shochary region: Manuscript on file, Pennsylvania Geol. Survey, $36 \mathrm{p}$.

White, I. C., 1882, The geology of Pike and Monroe Counties: Pennsylvania Geol: Survey, 2d ser., Rept. G6, 407 p.

1883, The geolosy of the Susquehanna River region in the six counties of Wyoming, Lackawanna, Luzerne, Columbia, Montour, and Northumberland: Pennsylvania Geol. Survey, 2d, Rept. G7, $464 \mathrm{p}$.

Whitten, E. H. T:, 1966, Structurel geology of folded rocks: Chicago, Rand NicNally \& Co., 663 p.

Willard, Bradford, 1928, The age and origin of the Shawangunk Formation: Jour. Paleontology, v. 1, p. 255-258.

1932, A jiarcellus fauna from Stroudsturg, Pennsylvania: Am. Jour. Sc1., 5th ser., v. 24, p. 147-151.

1935, Hamilton Group of central Pennsylvania: Geol. Soc. America Bull., v. 46, p. 195-224.

1936a, The Ononåaga Formation in Pennsylvania: Jour. Geology, v. 44, p. 578-603.

1936b, A Hamilton coral reef in Pennsylvania: Pennsylvania Acad. Sci. Proc., v. 10, p. 30-36.

1937, Hamilton correlations: Am. Jour. Sc1., 5th ser., v. 33, p. $264-278$.

1938, A Paleozoic section at Delaware Water Gap: Pennsylvania Geol. Survey, 4th ser., Bull. Gll, 35 p.

1939, The Devonian of Pennsylvania: Pennsylvania Geol. Survey, 4th ser., Bull. G19, 481 p.

1941, The Harrisburg axis: Pennsylvania Acad. Sc1. Proc., v. 15, p. 97-102.

1943, Ordovician clastic sedimentary rocks in Pennsylvania: Geol. Soc. America Bull., v. 54, p. 1067-1121.

1952, Lower Oriskany contact in eastern Pennsylvania: Pennsylvania Acad. Sci. Proc., v. 26, p. 71-77.

1953, Unsolved stratigraphic problems in northeastern Pennsylvania: Pennsylvania Acad. Sc1. Proc., v. 27, p. 106-113. 
Wright, F. B., 1896, The origin of the Wind Gap: Am. Geologist, v. $18, p .120-123$.

Yeakel, L. S., Jr., 1962, Tuscarora, Juniata, and Bald Eagle paleocurrents and paleogeography in the central Appalachians:

Geol. Soc. America Bull., v. 73, p. 2515-1540.

Yoder, H. S., 1955, Role of water in metamorphism: Geol. Soc. America Spec. Paper 62, p. 505-524.

Yoder, H. S., and Eugster, H. P., 1955, Synthetic and natural muscovites: Geochim. et Cosmochim. Acta, v. 8, p. 225-280. 